PNNL-21321

\title{
Fire Safety Tests for Spherical Resorcinol Formaldehyde Resin: Data Summary Report
}

D Kim

MJ Schweiger

RA Peterson

July 2012

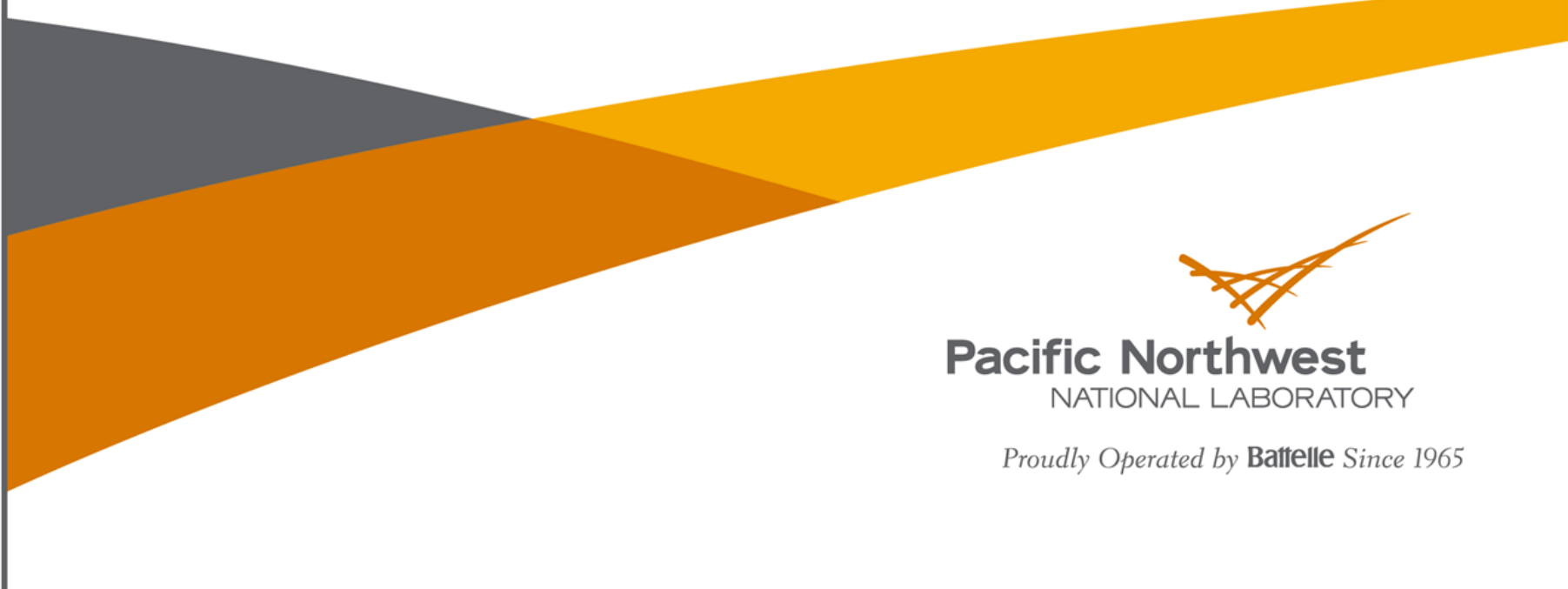




\title{
DISCLAIMER
}

This report was prepared as an account of work sponsored by an agency of the United States Government. Neither the United States Government nor any agency thereof, nor Battelle Memorial Institute, nor any of their employees, makes any warranty, express or implied, or assumes any legal liability or responsibility for the accuracy, completeness, or usefulness of any information, apparatus, product, or process disclosed, or represents that its use would not infringe privately owned rights. Reference herein to any specific commercial product, process, or service by trade name, trademark, manufacturer, or otherwise does not necessarily constitute or imply its endorsement, recommendation, or favoring by the United States Government or any agency thereof, or Battelle Memorial Institute. The views and opinions of authors expressed herein do not necessarily state or reflect those of the United States Government or any agency thereof.

\author{
PACIFIC NORTHWEST NATIONAL LABORATORY \\ operated by \\ BATTELLE \\ for the \\ UNITED STATES DEPARTMENT OF ENERGY \\ under Contract DE-AC05-76RL01830
}

Printed in the United States of America
Available to DOE and DOE contractors from the Office of Scientific and Technical Information, P.O. Box 62, Oak Ridge, TN 37831-0062; ph: (865) 576-8401 fax: $(865) \mathbf{5 7 6 - 5 7 2 8}$
email: reports@adonis.osti.gov

Available to the public from the National Technical Information Service 5301 Shawnee Rd., Alexandria, VA 22312 ph: (800) 553-NTIS (6847) email: orders@ntis.gov $<$ http://www.ntis.gov/about/form.aspx > Online ordering: http://www.ntis.gov 
PNNL-21321

WTP-RPT-218, Rev 0

\section{Fire Safety Tests for Spherical Resorcinol Formaldehyde Resin: Data Summary Report}

D Kim

MJ Schweiger

RA Peterson

July 2012

Test Specification: 24590 PTF-TSP-RT-09-002, Rev. 0

Test Plan: TP-WTPSP-002, Rev. 3.0

Test Exceptions: 24590-PTF-TEF-RT-11-00003, Rev. 0

R\&T Focus Area: Pretreatment

Test Scoping Statement: None

Prepared for the U.S. Department of Energy

Under Contract DE-AC05-76RL01830

Pacific Northwest National Laboratory

Richland, Washington 99352 



\section{Completeness of Testing}

This report describes the results of work and testing specified by Test Specification 24590-PTF-TSP-RT-09-002, Rev 0, and Test Plan TP-WTPSP-002, Rev. 3.0. The work followed the quality assurance requirements outlined in the test specification and test plan. The descriptions provided in this report are an accurate account of both the conduct of the work and the data collected. Test plan results are reported. Also reported are any unusual or anomalous occurrences that are different from expected results. The test results and this report have been reviewed and verified.

Approved:

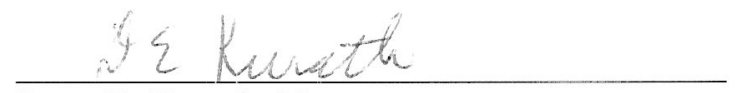

Dean E. Kurath, Manager WTP R\&'T Support Project

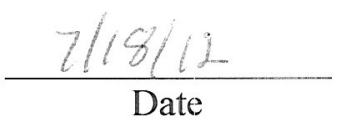





\section{Testing Summary}

A draft safety evaluation of the scenario for spherical resorcinol formaldehyde (SRF) resin fire inside the ion exchange column was performed by the Hanford Tank Waste Treatment and Immobilization Plant (WTP) Fire Safety organization. The result of this draft evaluation suggested a potential change of the fire safety classification for the Cesium Ion Exchange Process System (CXP) emergency elution vessels, equipment, and piping, which may be overly bounding based on the fire performance data from the manufacturer of the ion exchange resin selected for use at the WTP. To help resolve this question, key combustion properties of the SRF resin were measured by Southwest Research Institute (SwRI), following the American Society for Testing and Materials (ASTM) standard procedures, through a subcontract managed by Pacific Northwest National Laboratory (PNNL). For some tests, the ASTM standard procedures were not entirely appropriate or practical for the SRF resin material, so the procedures were modified and deviations from the ASTM standard procedures were noted.

This report summarizes the results of fire safety tests performed and reported by SwRI. The efforts by PNNL were limited to summarizing the test results provided by SwRI into one consolidated data report. All as-received SwRI reports are attached to this report in the Appendix. Where applicable, the precision and bias of each test method, as given by each ASTM standard procedure, are included and compared with the SwRI test results of the SRF resin.

\section{Objectives}

The objectives for the SRF resin fire safety tests were

- to determine whether the SRF resin is to ignite and burn at temperatures up to $750^{\circ} \mathrm{C}$

- to determine how much soot/smoke will be generated if the SRF resin burns or smolders

- to determine the size of particulates generated if the SRF resin does generate soot/smoke.

Table S.1 provides the objectives that applied to the SRF resin fire safety tests.

\section{Test Exceptions}

The test exception in Test Plan TP-WTPSP-002, Rev 3, that was applicable to this testing is presented in Table S.2.

\section{Results and Performance Against Success Criteria}

Success criteria for achieving the test objectives are discussed in Table S.3. 
Table S.1. Summary of Test Objectives and Results

\begin{tabular}{|c|c|c|}
\hline Test Objective & $\begin{array}{c}\text { Objective } \\
\text { Met? }\end{array}$ & Discussion \\
\hline $\begin{array}{l}\text { Determine whether the SRF } \\
\text { resin is to ignite and burn at } \\
\text { temperatures up to } 750^{\circ} \mathrm{C} \text {. }\end{array}$ & Yes & $\begin{array}{l}\text { The flash ignition temperature (FIT) and spontaneous ignition } \\
\text { temperature (SIT) were determined in accordance with ASTM } \\
\text { D1929-96. The average values of FIT and SIT from duplicate } \\
\text { tests were } 595^{\circ} \mathrm{C} \text { and } 613^{\circ} \mathrm{C} \text {, respectively. The results are } \\
\text { summarized in Section } 4.1 \text {. }\end{array}$ \\
\hline $\begin{array}{l}\text { Determine how much } \\
\text { soot/smoke will be generated } \\
\text { if the SRF resin burns or } \\
\text { smolders. }\end{array}$ & Yes & $\begin{array}{l}\text { The specific smoke extinction area (SEA), which is a ratio of } \\
\text { smoke production to specimen mass loss, was measured in } \\
\text { accordance with ASTM E1354-10. The average SEA was } \\
13 \mathrm{~m}^{2} / \mathrm{kg} \text { from duplicate runs. The specific optical density }\left(D_{s}\right) \\
\text { of smoke generated from a constant irradiation of } 25 \mathrm{~kW} / \mathrm{m}^{2} \text { was } \\
\text { determined in general accordance with ASTM E662-09 with } \\
\text { deviations as described in Section } 3.5 \text {. The average maximum } D_{s} \\
\text { values were } 0.65 \text { under flaming condition and } 0.35 \text { under } \\
\text { nonflaming condition obtained from duplicate runs. The results } \\
\text { are summarized in Section } 4.4 \text {. }\end{array}$ \\
\hline $\begin{array}{l}\text { Determine the size of } \\
\text { particulates generated if the } \\
\text { SRF resin does generate } \\
\text { soot/smoke. }\end{array}$ & Yes & $\begin{array}{l}\text { The particle size distribution of smoke generated from a constant } \\
\text { irradiation of } 25 \mathrm{~kW} / \mathrm{m}^{2} \text { was determined during smoke evaluation } \\
\text { tests that were performed in general accordance with ASTM } \\
\text { E662-09 (no applicable standard procedures for smoke particle } \\
\text { size determination). The median diameter }\left(d_{50}\right) \text { was } 2.4 \mu \mathrm{m} \\
\text { under nonflaming condition and } 4.0 \mu \mathrm{m} \text { under flaming condition. } \\
\text { Under nonflaming condition, the largest particle was } 7.2 \mu \mathrm{m} \text { and } \\
\text { about } 1.5 \% \text { of the particles were smaller than } 0.52 \mu \mathrm{m} \text {. Under } \\
\text { flaming condition, the largest particle was } 11.1 \mu \mathrm{m} \text { and only } \\
\text { about } 0.3 \% \text { of the particles were smaller than } 0.52 \mu \mathrm{m} \text {. }\end{array}$ \\
\hline
\end{tabular}

Table S.2. Test Exception

Test Exception Number

Description of Test Exception

24590-PTF-TEF-RT-11-00003, Rev 0 This test exception was received from Bechtel National, Inc. (BNI) on September 9, 2011. It incorporates the approved Request for Technology Development (RTD), 24590-WTP-RTD-RT-11-0001, Rev 0, which requests data on the fire safety limits for soot/particulate generation and ignition temperature for the SRF ion exchange resin. 
Table S.3. Success Criteria for Achieving Test Objectives

List Success Criteria

1. Provide test results for high-temperature analysis of resin to determine flash ignition/spontaneous ignition temperatures.

2. Provide test results that include heat release rates and mass/soot/smoke yield if SRF resin were to burn or smolder.

3. Provide particle size distribution analysis of soot generated by SRF resin.
Explain How the Tests Did or Did Not Meet the Success Criteria

This success criterion was met. The flash ignition and spontaneous ignition temperatures were measured in accordance with ASTM D1929-96. The flash ignition temperature was $595^{\circ} \mathrm{C}$, and spontaneous ignition temperature was $613^{\circ} \mathrm{C}$.

This success criterion was met. The heat release rates and specific smoke extinction area were measured in accordance with ASTM E1354-10 and ASTM D7309-07A. The peak heat release rate was $52 \mathrm{~kW} / \mathrm{m}^{2}$, and the maximum specific heat release rate was $21.6 \mathrm{~W} / \mathrm{g}$ in an oxygen-free environment and $124.6 \mathrm{~W} / \mathrm{g}$ in an oxidizing environment. The specific smoke extinction area was $13 \mathrm{~m}^{2} / \mathrm{kg}$. The specific optical density of smoke generated from a constant irradiation of $25 \mathrm{~kW} / \mathrm{m}^{2}$ was determined in general accordance with ASTM E662-09 with deviations as described in Section 3.5. The average maximum specific optical density was 0.65 under a flaming condition and 0.35 under a nonflaming condition.

This success criterion was met. The particle size distribution of the smoke was determined in general accordance with ASTM E662-09 (no applicable standard procedures for smoke particle size determination). The median diameter $\left(d_{50}\right)$ was $2.4 \mu \mathrm{m}$ under nonflaming condition and $4.0 \mu \mathrm{m}$ under flaming condition. Under nonflaming condition, the largest particle was $7.2 \mu \mathrm{m}$ and about $1.5 \%$ of the particles were smaller than $0.52 \mu \mathrm{m}$. Under flaming condition, the largest particle was $11.1 \mu \mathrm{m}$ and only about $0.3 \%$ of the particles were smaller than $0.52 \mu \mathrm{m}$. 


\section{Quality Requirements}

The PNNL Quality Assurance (QA) Program is based on the requirements defined in U.S. Department of Energy Order 414.1D, Quality Assurance, and 10 CFR 830, Energy/Nuclear Safety Management, Subpart A - Quality Assurance Requirements (a.k.a. the Quality Rule). PNNL has chosen to implement the following consensus standards in a graded approach:

- ASME NQA-1-2000, Quality Assurance Requirements for Nuclear Facility Applications, Part I, Requirements for Quality Assurance Programs for Nuclear Facilities

- ASME NQA-1-2000, Part II, Subpart 2.7, Quality Assurance Requirements for Computer Software for Nuclear Facility Applications

- ASME NQA-1-2000, Part IV, Subpart 4.2, Graded Approach Application of Quality Assurance Requirements for Research and Development.

The Waste Treatment Plant Support Project (WTPSP) implements an NQA-1-2000 Quality Assurance Program, graded on the approach presented in NQA-1-2000, Part IV, Subpart 4.2. The WTPSP Quality Assurance Manual (QA-WTPSP-0002) describes the technology life-cycle stages under the WTPSP Quality Assurance Plan (QA-WTPSP-0001). The technology life cycle includes the progression of technology development, commercialization, and retirement in process phases of basic and applied research and development (R\&D), engineering and production, and operation until process completion. The life cycle is characterized by flexible and informal quality assurance activities in basic research that become more structured and formalized through the applied R\&D stages.

The work described in this report has been completed under the QA technology level of Applied Research. The WTPSP addresses internal verification and validation activities by conducting an independent technical review of the final data report in accordance with WTPSP procedure QA-WTPSP-601, Document Preparation and Change. This review verifies that the reported results are traceable, that inferences and conclusions are soundly based, and that the reported work satisfies the test plan objectives.

The Southwest Research Institute, who performed the tests described in this report, is listed on the PNNL Approved Suppliers List.

\section{Test Conditions}

This report summarizes the fire test results performed by SwRI and submitted to PNNL.

All test conditions delineated by the test plan and test exceptions were met. A summary of test conditions is provided in Table S.4.

\section{Simulant Use}

Simulant was not developed for the tests summarized in this report. The SRF resin was manufactured by Microbeads AS, a Norwegian company (www.micro-beads.com), and shipped in an approximately100-L steel drum. WTP provided the entire drum to PNNL. About $20 \mathrm{~L}$ of the resin were shipped to SwRI in a 20-L carboy. 
Table S.4. Test-Condition Summary

Test Conditions

Were Test Conditions Followed?

1. Fire safety testing will also be performed to obtain data on potential soot and combustion byproducts generated by an ion exchange resin fire to assist the WTP Project in assessing off-gas filtration requirements. An independent laboratory will conduct tests using WTP-supplied SRF resin. The testing will include standard small-scale fire behavior characterization testing according to ASTM E1354-10, Standard Test Method for Heat and Visible Smoke Release Rates Using an Oxygen Consumption Calorimeter; ASTM D1929-96, Standard Test Method for Determining Ignition Temperature; ASTM D7309-07A, Standard Test Method for Determining Flammability Characteristics of Plastics and Other Solid Materials Using Microscale Combustion Calorimetry; ASTM E800-07, Standard Measurement of Gasses Present Or Generated During Fires Using Gas Sampling Protocol; and ASTM E662-09, Standard Test Method for Specific Optical Density of Smoke Generated by Solid Materials.

Fire safety testing was performed by an independent laboratory, Southwest Research Institute. The WTP-supplied SRF resin was filtered and then dried for 2 to $12 \mathrm{~h}$ depending on the amount of material required for each test at $70^{\circ} \mathrm{C}$ before testing. All tests were performed in general accordance with the standard procedures: ASTM E1354-10, ASTM D1929-96, ASTM D7309-07A, ASTM E800-07, and ASTM E662-09, except for the deviations from ASTM E662-09 in the following items: 1) furnace, 2) pilot burner, and 3 ) drying condition (see Section 3.5 for detailed descriptions and Table 3.1 for a summary).

\section{Discrepancies and Follow-On Tests}

Large differences in $\mathrm{CO}$ and $\mathrm{CO}_{2}$ concentrations were observed between duplicate tests (Table 4.8). SwRI performed careful review of the raw data files to investigate the potential cause of these large differences and did not find any indication that the tests were done incorrectly. It is suspected that the large differences are likely due to the characteristics inherent to the present SRF resin material. It is suggested that the gas analyses be repeated so that the assumption on the characteristics of the SRF resin may be checked. 



\section{Acknowledgments}

The authors thank the Southwest Research Institute (Eugene Horton and SwRI staff, San Antonio, Texas) for test support. The authors also thank Jennifer Meehan and David Sherwood of the Hanford Tank Waste Treatment and Immobilization Plant project for their technical insights and much helpful discussion and support. The authors are grateful for the assistance of Renee Russell for her technical review. In addition, the authors thank Casey D. Emery, PNNL Contracts Department, for his diligent effort in negotiating this contract. 



\section{Acronyms and Abbreviations}

ASTM

BNI

CHF

CXP

DOE

$\mathrm{EHC}$

FIT

FPI

FTIR

GGRF

HRR

$\mathrm{HRR}_{\text {peak }}$

ISO

MLR

ORP

PMMA

PNNL

PTF

QA

R\&D

$\mathrm{RF}$

RTD

SEA

SIT

SRF

SwRI

THR

TRP

WTP

WTPSP
American Society for Testing and Materials

Bechtel National, Inc.

critical heat flux

Cesium Ion Exchange Process System

U.S. Department of Energy

effective heat of combustion

flash ignition temperature

fire propagation index

Fourier transform infrared

ground gel resorcinol-formaldehyde

heat release rate

peak heat release rate

International Organization for Standardization

mass loss rate

Office of River Protection

poly methyl methacrylate

Pacific Northwest National Laboratory

pretreatment facility

quality assurance

research and development

resorcinol formaldehyde

request for technology development

specific smoke extinction area

spontaneous ignition temperature

spherical resorcinol formaldehyde

Southwest Research Institute

total heat release

thermal response parameter

Hanford Tank Waste Treatment and Immobilization Plant

Waste Treatment Plant Support Project 


\section{Symbols}

\begin{tabular}{|c|c|}
\hline$A$ & exposed area of test sample \\
\hline$a, b$ & linear regression coefficients for repeatability or reproducibility \\
\hline$d_{50}$ & median diameter \\
\hline$D_{m}$ & mass optical density of smoke \\
\hline$D_{s}$ & specific optical density of smoke \\
\hline$h_{c}$ & specific heat release \\
\hline$h_{c, g a s}$ & specific heat of combustion of specimen gases \\
\hline$I$ & intensity of light transmitted through smoke \\
\hline$I^{0}$ & intensity of incident light \\
\hline$K$ & light extinction coefficient \\
\hline$k_{c}$ & convection coefficient \\
\hline$L$ & light path length \\
\hline$\Delta m$ & mass loss \\
\hline$\Delta m_{s}$ & mass loss per unit sample surface area \\
\hline$Q_{\max }$ & maximum specific heat release rate \\
\hline$r$ & repeatability limit \\
\hline$R$ & reproducibility limit \\
\hline$S_{A}$ & total smoke production per unit sample area \\
\hline$S_{r}$ & standard deviation for repeatability limit $(r)$ \\
\hline$s_{R}$ & standard deviation for reproducibility limit $(R)$ \\
\hline$T_{i g}$ & surface temperature at ignition \\
\hline$t_{i g}$ & time to ignition \\
\hline$t_{T}$ & total test duration \\
\hline$T_{\max }$ & heat release temperature \\
\hline$T_{\infty}$ & ambient temperature \\
\hline$V$ & volume of test chamber \\
\hline$\dot{V}$ & volume flow rate of exhaust at the location of the light extinction measurement \\
\hline$Y_{p}$ & pyrolysis residue \\
\hline$\varepsilon$ & surface emissivity \\
\hline$\eta$ & heat release capacity \\
\hline$\sigma$ & Stefan-Boltzmann constant \\
\hline
\end{tabular}




\section{Contents}

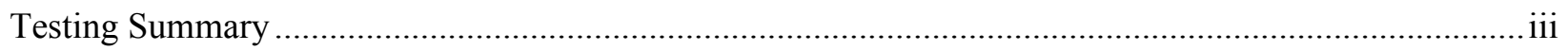

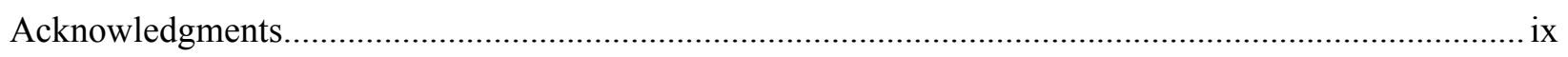

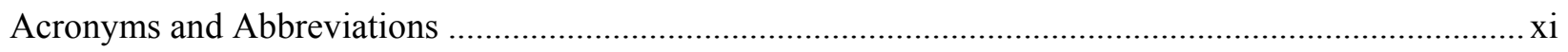

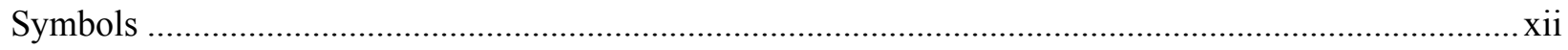

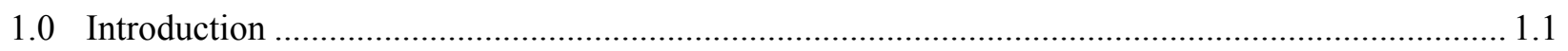

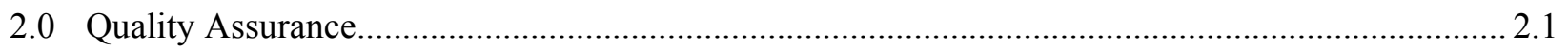

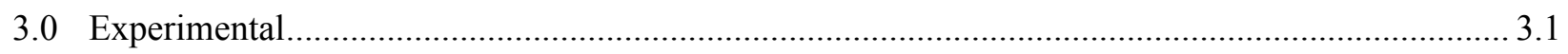

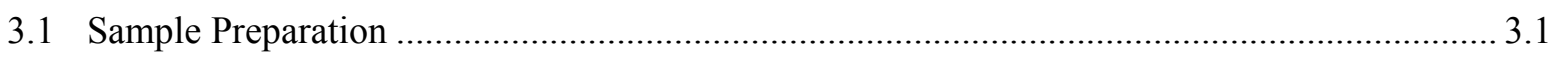

3.2 Flash Ignition Temperature and Spontaneous Ignition Temperature Using Hot-Air

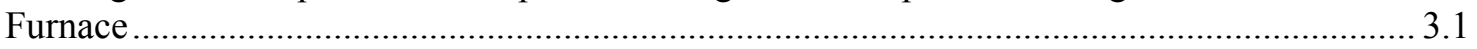

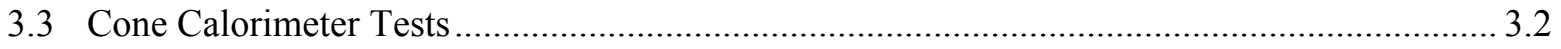

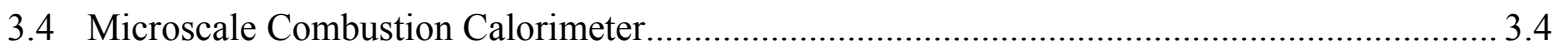

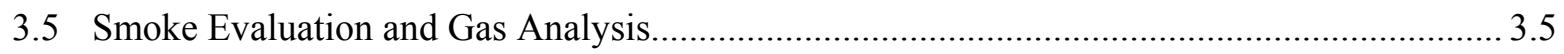

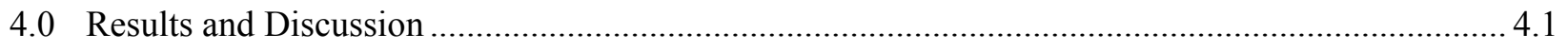

4.1 Flash Ignition Temperature and Spontaneous Ignition Temperature .................................... 4.1

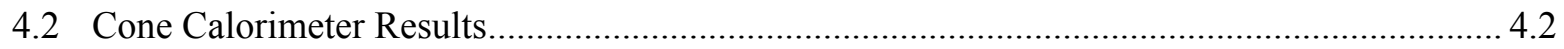

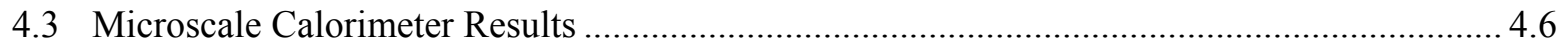

4.4 Smoke Particle Size and Specific Optical Density ............................................................. 4.7

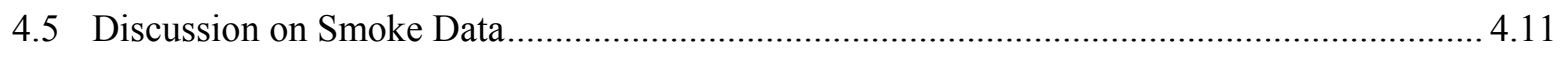

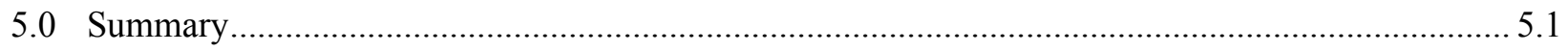

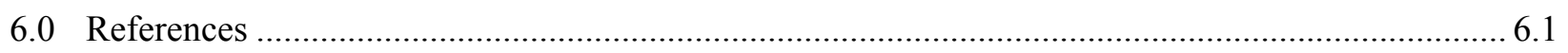

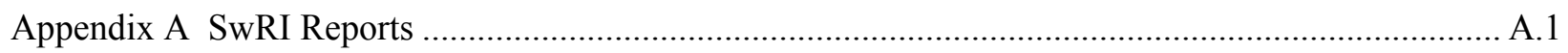




\section{Figures}

3.1. Schematic of Southwest Research Institute Hot-Air Furnace ......................................................... 3.2

3.2. Schematic of Cone Calorimeter Apparatus ................................................................................... 3.3

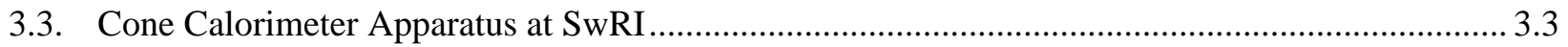

3.4. Schematic of Microscale Combustion Calorimeter.......................................................................... 3.5

4.1. Time to Ignition as a Function of External Heat Flux to Determine the TRP................................. 4.5

4.2. Smoke Particle Size Distribution of SRF Resin Under Nonflaming Condition.............................. 4.8

4.3. Smoke Particle Size Distribution of SRF Resin Under Flaming Condition................................... 4.8

4.4. Smoke Particle Size Distribution of Negative Standard Under Nonflaming Condition .................. 4.9

4.5. Smoke Particle Size Distribution of Positive Standard Under Flaming Condition......................... 4.9

\section{Tables}

3.1. Standard Procedures Used by Southwest Research Institute ....................................................... 3.7

4.1. Flash Ignition Temperature and Spontaneous Ignition Temperature of SRF Resin ...................... 4.2

4.2. Results from Cone Calorimeter Tests of SRF Resin Performed at $100 \mathrm{~kW} / \mathrm{m}^{2}$ Heat Flux ............. 4.3

4.3. Average Surface Temperature at Ignition and Extrapolated and Bracketed Critical Heat

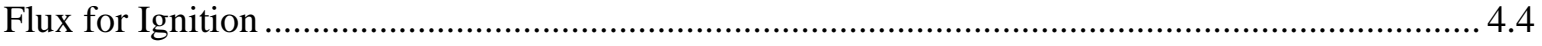

4.4. Summary of Cone Calorimeter Test Results and Calculated Fire Propagation Index (FPI)

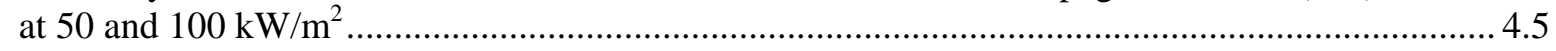

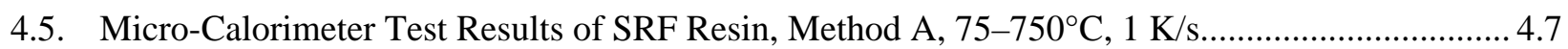

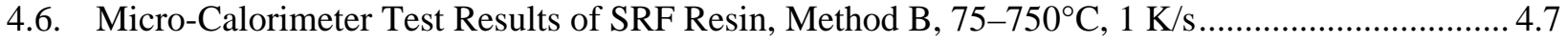

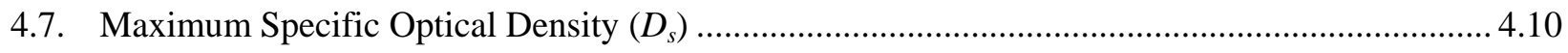

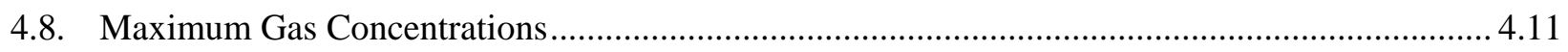

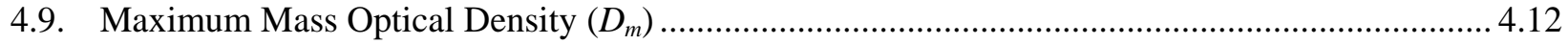

4.10. Summary of Particle Size Distribution Measurement Results ..................................................... 4.13

5.1. Summary of Fire Test Results on SRF Resin.......................................................................... 5.1 


\subsection{Introduction}

Ion exchange using the spherical resorcinol-formaldehyde (SRF) resin has been selected by Bechtel National, Inc. (BNI) and approved by the U.S. Department of Energy (DOE) Office of River Protection (ORP) for use in the Pretreatment Facility (PTF) of the Hanford Tank Waste Treatment and Immobilization Plant (WTP). SRF is an engineered spherical form of the older ground gel resorcinol-formaldehyde (GGRF) resin, also termed resorcinol-formaldehyde (RF).

A draft safety evaluation of the scenario for resin fire inside the ion exchange column was performed by the WTP Fire Safety organization. The result of this draft evaluation suggested a potential change of the fire safety classification for the Cesium Ion Exchange Process System (CXP) emergency elution vessels, equipment, and piping. To help resolve this question, key combustion properties of the SRF resin were measured by Southwest Research Institute (SwRI), following the standard procedures, through a subcontract managed by Pacific Northwest National Laboratory (PNNL).

Section 2.0 details the basis of the PNNL Quality Assurance (QA) Program as applied to the WTP quality requirements. PNNL QA program was flowed down to SwRI. Section 3.0 describes the test methods and ASTM standard procedures used in this testing. Section 4.0 summarizes the results of the experimental tests performed by SwRI. Section 5.0 provides all test results summarized in one table. Section 6.0 provides a list of pertinent references. All as-received SwRI reports are included in the Appendix. Some errors found in the as-received SwRI reports were corrected and additional data that were missing in the as-received reports were added to this summary report. 



\subsection{Quality Assurance}

The PNNL Quality Assurance (QA) Program is based on the requirements defined in U.S. Department of Energy Order 414.1D, Quality Assurance, and 10 CFR 830, Energy/Nuclear Safety Management, Subpart A - Quality Assurance Requirements (a.k.a. the Quality Rule). PNNL has chosen to implement the following consensus standards in a graded approach:

- ASME NQA-1-2000, Quality Assurance Requirements for Nuclear Facility Applications, Part I, Requirements for Quality Assurance Programs for Nuclear Facilities

- ASME NQA-1-2000, Part II, Subpart 2.7, Quality Assurance Requirements for Computer Software for Nuclear Facility Applications

- ASME NQA-1-2000, Part IV, Subpart 4.2, Graded Approach Application of Quality Assurance Requirements for Research and Development.

The Waste Treatment Plant Support Project (WTPSP) implements an NQA-1-2000 Quality Assurance Program, graded on the approach presented in NQA-1-2000, Part IV, Subpart 4.2. The WTPSP Quality Assurance Manual (QA-WTPSP-0002) describes the technology life-cycle stages under the WTPSP Quality Assurance Plan (QA-WTPSP-0001). The technology life cycle includes the progression of technology development, commercialization, and retirement in process phases of basic and applied research and development $(\mathrm{R} \& \mathrm{D})$, engineering and production, and operation until process completion. The life cycle is characterized by flexible and informal quality assurance activities in basic research that become more structured and formalized through the applied R\&D stages.

The work described in this report has been completed under the QA technology level of Applied Research. WTPSP addresses internal verification and validation activities by conducting an independent technical review of the final data report in accordance with WTPSP's procedure QA-WTPSP-601, Document Preparation and Change. This review verifies that the reported results are traceable, that inferences and conclusions are soundly based, and that the reported work satisfies the test plan objectives.

The Southwest Research Institute, who performed the tests described in this report, is listed on the PNNL Approved Suppliers List. 



\subsection{Experimental}

This section describes the test methods and procedures used by SwRI to perform various fire safety tests on the SRF resin provided by PNNL. Table 3.1, presented at the end of this section, summarizes the ASTM standard test procedures used by SwRI for this testing.

All tests were performed in duplicate. For cone calorimeter, microscale combustion calorimeter, and smoke density tests, each run consisted of three tests (total six tests) as required by ASTM standards.

\subsection{Sample Preparation}

PNNL provided SwRI with one 20-L carboy of SRF resin that consisted of a micro bead resin material dispersed in water. For all tests described in this report, the sample was filtered and then dried for 2 to $12 \mathrm{~h}$ depending on the amount of material required for each test in an oven at $70^{\circ} \mathrm{C}$ prior to testing. This temperature was chosen not to over-dry the resin. The resin was constantly monitored to achieve a consistency in drying condition gauged by the color. After drying, the sample consisted of only the micro bead material. The beads became statically charged in the absence of the water medium, so they were placed in a closed container after drying in an effort not to lose any beads. Each sample was then stored in a controlled environment maintained at $23^{\circ} \mathrm{C} \pm 3{ }^{\circ} \mathrm{C}$ and $50 \% \pm 5 \%$ relative humidity until just prior to testing.

\subsection{Flash Ignition Temperature and Spontaneous Ignition Temperature Using Hot-Air Furnace}

The flash ignition temperature (FIT) and spontaneous ignition temperature (SIT) of SRF resin were determined using a hot-air furnace according to ASTM D1929-96, Standard Test Method for Determining Ignition Temperature. The hot-air ignition furnace consists primarily of an electrical heating unit and specimen holder. The furnace tube is a vertical tube with an inside diameter of $100 \pm 5 \mathrm{~mm}$ and a length of $230 \pm 20 \mathrm{~mm}$, made of ceramic that will withstand at least $750^{\circ} \mathrm{C}$. The inner ceramic tube, with an inside diameter of $75 \pm 5 \mathrm{~mm}$, a length of $230 \pm 20 \mathrm{~mm}$, and a thickness of approximately $3 \mathrm{~mm}$, is placed inside the furnace tube and positioned $20 \pm 2 \mathrm{~mm}$ above the furnace floor on spacer blocks. The pilot flame is located immediately above the opening. The test apparatus is shown in Figure 3.1.

The FIT is the minimum temperature at which, under specified test conditions, sufficient flammable gases are emitted to ignite momentarily upon application of a small external pilot flame. The lowest air temperature at which a flash is observed during a 10-min period is recorded as the FIT.

The SIT is the minimum temperature at which the self-heating properties of the specimen lead to ignition or ignition occurs spontaneously, under specified test conditions, in the absence of any additional flame ignition source. The lowest air temperature at which the specimen ignites during a 10-min period is recorded as the SIT. 


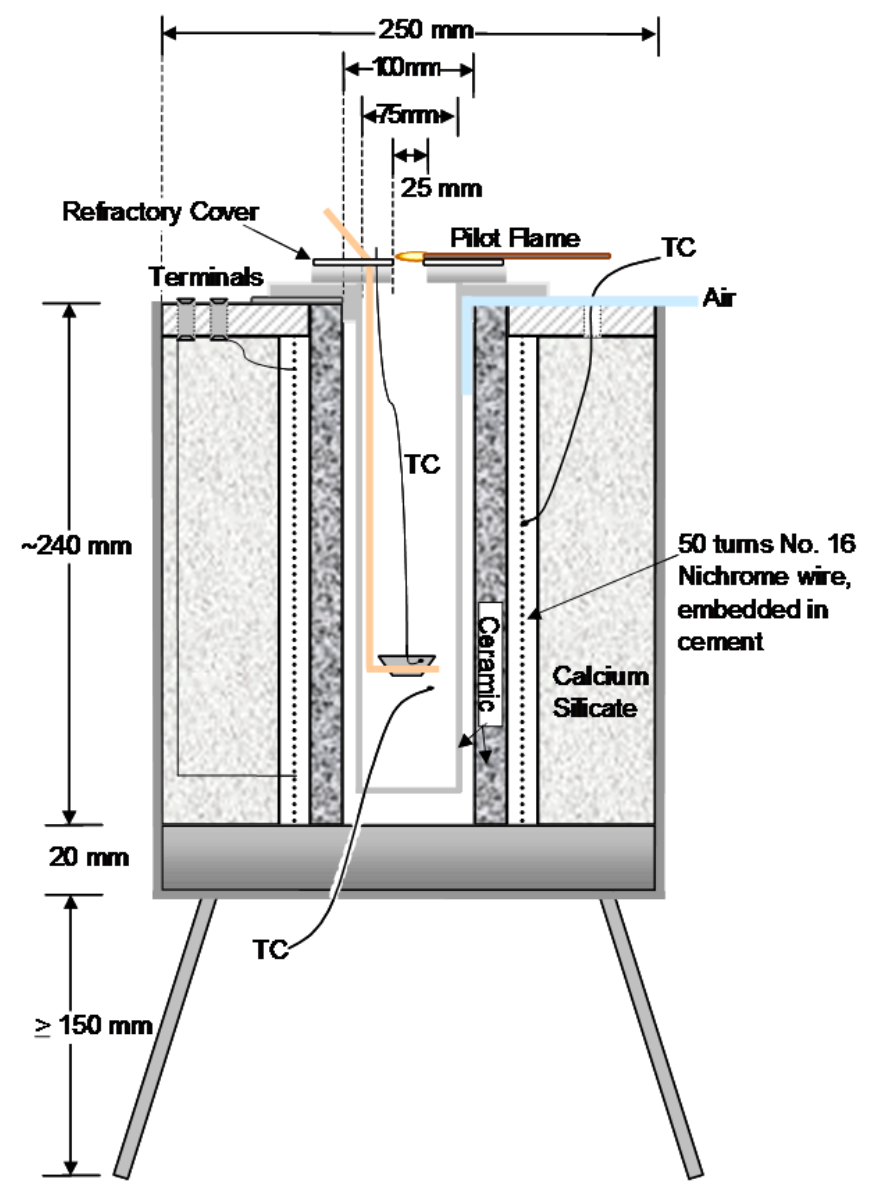

Figure 3.1. Schematic of Southwest Research Institute Hot-Air Furnace (from SwRI report for R13295.12.008a)

\subsection{Cone Calorimeter Tests}

Heat release rate (HRR, $\mathrm{kW} / \mathrm{m}^{2}$ ), mass loss rate (MLR, $\left.\mathrm{g} /\left[\mathrm{m}^{2} \mathrm{~s}\right]\right)$, effective heat of combustion (EHC, MJ $/ \mathrm{kg}$ ), and specific smoke extinction area (SEA, $\mathrm{m}^{2} / \mathrm{kg}$ ) of SRF resin were determined using a cone calorimeter according to ASTM E1354-10, Standard Test Method for Heat and Visible Smoke Release Rates for Materials and Products Using an Oxygen Consumption Calorimeter.

The cone calorimeter is a small-scale test apparatus that measures primarily the rate of heat release of materials and products under a wide range of conditions using the oxygen consumption technique. A schematic of the cone calorimeter apparatus is provided in Figure 3.2. The cone calorimeter used for tests at SwRI is shown in Figure 3.3.

For organic solids, liquids, and gases, a nearly constant net amount of heat is released per unit mass of oxygen consumed for complete combustion. An average value for this constant of $13.1 \mathrm{MJ} / \mathrm{kg}$ of oxygen can be used for practical applications and is accurate with very few exceptions to within $\pm 5 \%$. Therefore, measurements of the oxygen consumed in a combustion system can be used to determine the net heat released. This technique, generally referred to as the "oxygen consumption technique," is now the most widely used and accurate method for measuring heat release rate in experimental fires. 


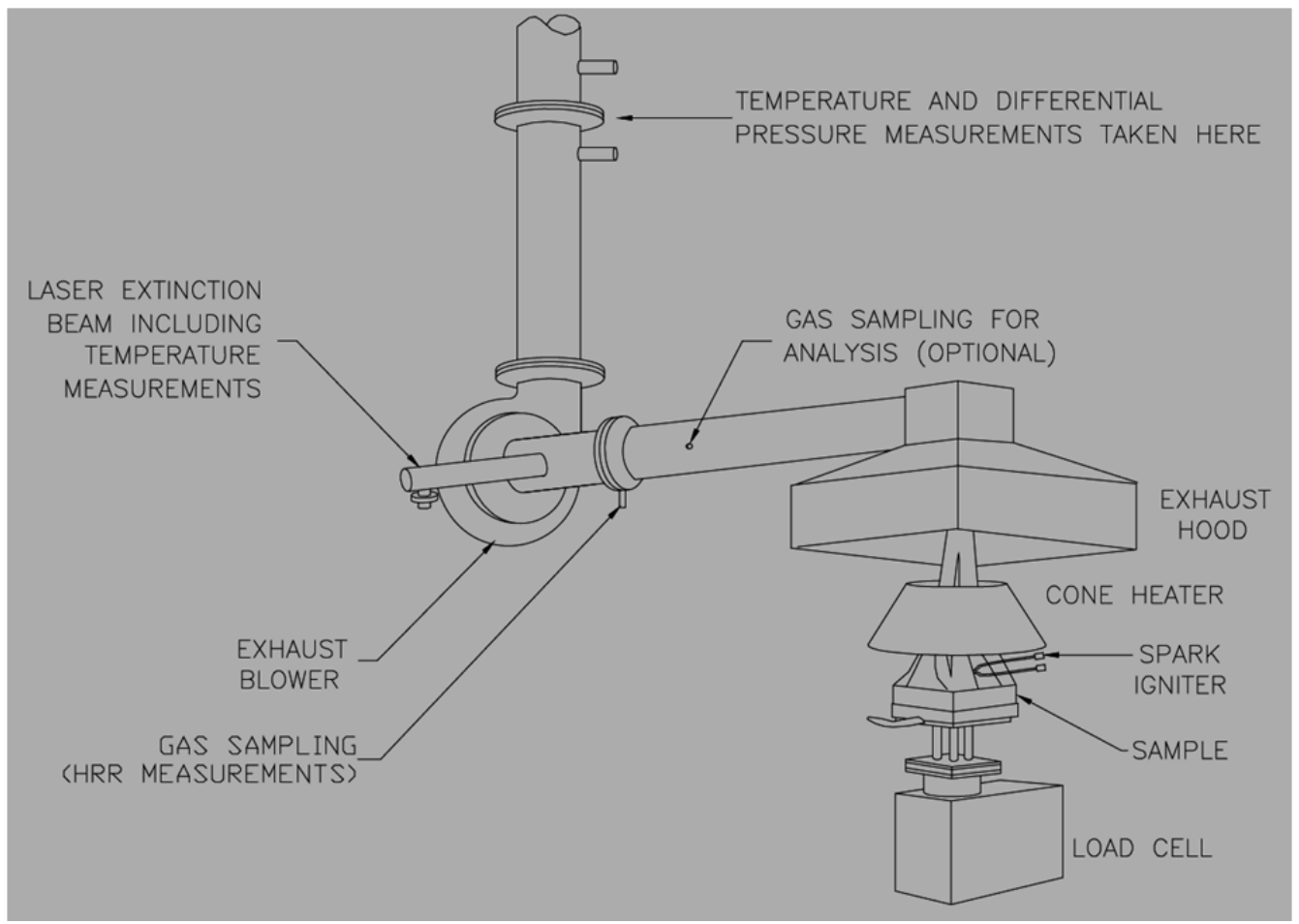

Figure 3.2. Schematic of Cone Calorimeter Apparatus (from SwRI report for R13295.12.008b)

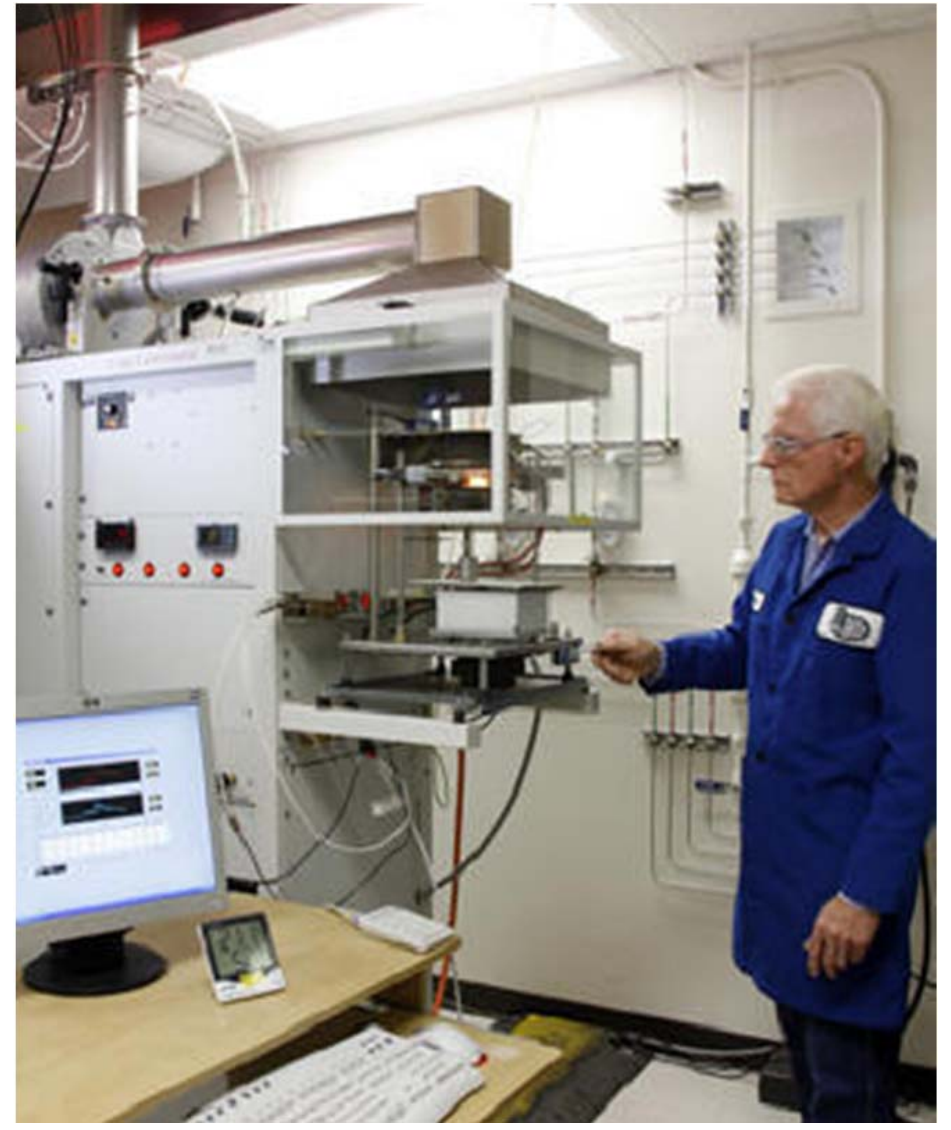

Figure 3.3. Cone Calorimeter Apparatus at SwRI 
In the cone calorimeter, a square sample $100 \times 100 \mathrm{~mm}(4 \times 4 \mathrm{in}$. $)$ is exposed to the radiant flux of an electric heater. The heater has the shape of a truncated cone (hence the name of the instrument) and is capable of providing heat fluxes to the specimen in the range of $0-110 \mathrm{~kW} / \mathrm{m}^{2}$. An electric spark igniter is used for piloted ignition of the pyrolysis gases produced by the radiant heater.

Prior to testing, the test specimen is wrapped in aluminum foil, backed with a layer of low-density refractory fiber blanket, and placed in a standard specimen holder. At the start of a test, the specimen in the appropriate holder is placed on the load cell located below the heater. The top edge of the specimen is positioned $25 \mathrm{~mm}$ below the base plate of the heater. The electric spark igniter is located $13 \mathrm{~mm}$ above the center of the specimen. The electric spark igniter is removed $4 \mathrm{~s}$ after the pyrolysis gases are released by the specimen ignition.

The products of combustion and entrained air are collected in a hood and extracted through an exhaust duct by a fan. A gas sample is drawn from the exhaust duct and analyzed for oxygen concentration. The gas temperature and differential pressure across an orifice plate are used for calculating the mass flow rate of the exhaust gases. Smoke production is determined based on the measured light obscuration in the duct using a laser photometer located close to the gas sampling point.

\subsection{Microscale Combustion Calorimeter}

Specific heat release rate of the SRF resin was determined using a microscale combustion calorimeter according to ASTM D7309-07A, Standard Test Method for Determining Flammability Characteristics of Plastics and Other Solid Materials Using Microscale Combustion Calorimetry.

Similar to a cone calorimeter, a microscale calorimeter is a small-scale test apparatus that also uses the oxygen consumption technique to measure the rate of heat release of materials and products. The ASTM D7309-07A apparatus (see Figure 3.4) consists primarily of two heating chambers and a specimen holder (a part of the specimen thermocouple post). The heating chambers are two sections of a vertical tube. The sample sits in the pyrolysing chamber, and the pyrolysis gases move up toward the combustor furnace.

The combustor furnace was set at $900^{\circ} \mathrm{C}$. The pyrolysis chamber was set at $75^{\circ} \mathrm{C}$ and was ramped up to $850^{\circ} \mathrm{C}$ at a specified heating rate of $1 \mathrm{~K} / \mathrm{s}$. The ASTM D7309-07A standard specifies two different test methods. Method A is controlled thermal decomposition, and Method B is controlled thermal oxidative decomposition. The primary difference between the two methods is the point at which the oxygen is introduced. In Method A, the purge gas nitrogen flows through the pyrolyser section, then the nitrogen/oxygen mixture, along with any pyrolysis gases emitted from the sample, travel through the combustor furnace. In this method, the heat of combustion of the volatile components (gases) is measured, but the heat of combustion of any solid residue is not. In Method B, the nitrogen/oxygen mixture is introduced into the pyrolyser section. In this method, the net calorific value of the specimen gases and solid residue are measured. Because Method A can be used to obtain the heat release capacity $\eta_{\mathrm{c}}(\mathrm{J} / \mathrm{g}-\mathrm{K})$, which is a flammability parameter unique to this test method, Method A is typically used. The heat release rate is calculated based on oxygen consumption, and the specimen mass loss is determined based on weight measurements before and after testing. 


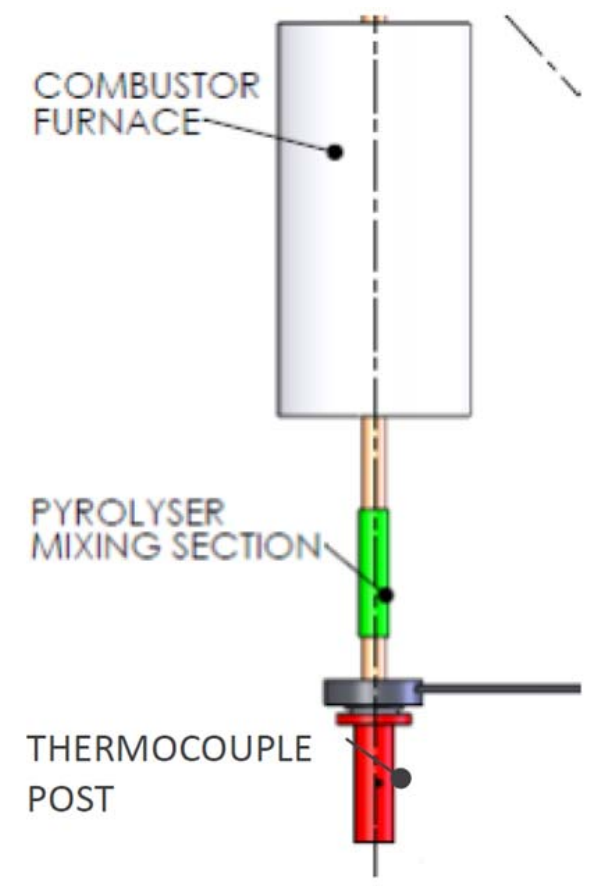

Figure 3.4. Schematic of Microscale Combustion Calorimeter (from SwRI report for R13295.12.008d)

\subsection{Smoke Evaluation and Gas Analysis}

Specific optical density of smoke was determined in general accordance with ASTM E662-09, Standard Test Method for Specific Optical Density of Smoke Generated by Solid Materials. The gas analysis was performed using the Fourier transform infrared (FTIR) spectroscopy according to ASTM E800-07, Standard Guide for Measurement of Gases Present or Generated During Fires. Because there is no applicable standard procedure, the particle size distribution was measured following the same procedure used for specific optical density determination.

A radiant heat furnace was used to provide a constant irradiance of $25 \mathrm{~kW} / \mathrm{m}^{2}$ in two exposures, flaming and nonflaming. A nonflaming exposure was used to determine smoke particle size distribution. Specific optical density measurement of smoke was performed under both flaming and nonflaming exposures. The furnace was not the same as that prescribed in procedure ASTM E662. Because the material could not sit in the sample holder in a vertical orientation, the International Organization for Standardization (ISO) 5659 furnace (a radiator cone) was used. The ISO 5659 is a similar smoke generation test which is typically run in the horizontal orientation. A pilot flame is used during flaming exposure and is centered in front of and parallel to the specimen holder. The pilot flame is also different from that prescribed in the ASTM E662-09 procedure, which is a six-flamed pilot burner. Instead, the ISO 5659 single-flame pilot burner was used because this ISO 5659 burner is more appropriate for the present tests using the ISO 5659 furnace.

ASTM E662-09 standard requires samples to be dried for $24 \mathrm{~h}$ at $60^{\circ} \mathrm{C} \pm 3^{\circ} \mathrm{C}\left(140^{\circ} \mathrm{F} \pm 5^{\circ} \mathrm{F}\right)$ prior to testing. However, the pre-drying condition described in Section 3.1 was already selected as the best condition for the present material and therefore it was determined that a $24 \mathrm{~h}$ drying is not necessary. Test specimens measuring $3 \times 3$ in., $+0,-0.03$ in. $(76.2 \times 76.2 \mathrm{~mm},+0,-0.8 \mathrm{~mm})$ were covered across 
the back and along the edges with a single sheet of aluminum foil with the dull side in contact with the specimen.

Specific optical density measurement was conducted for 10 min unless a minimum light transmittance value had not yet occurred, in which case the test was continued for an additional $10 \mathrm{~min}$. Notes were made relevant to any burning characteristics such as delamination, intumescence, shrinkage, and ignition. Test runs were carried out with a chamber wall temperature of $35^{\circ} \mathrm{C} \pm 2^{\circ} \mathrm{C}\left(95^{\circ} \mathrm{F} \pm 4^{\circ} \mathrm{F}\right)$. The tests for smoke particle size distribution were conducted for $20 \mathrm{~min}$.

Specific optical density measurement was made based on the attenuation of a vertically oriented light beam through smoke accumulating within the chamber. Results are expressed in terms of the dimensionless specific optical density, $D_{s}$. A clear beam value was recorded upon evacuation of smoke from the box to determine a correction factor. The maximum corrected specific optical density value from each of the runs at a single exposure condition were averaged and reported. Per the standard procedure, smoke density values were rounded to two significant figures.

Gas analysis was performed during the third measurement for specific optical density in flaming and nonflaming exposures using an FTIR spectrometer. The sample was drawn through a preheated line to prevent condensation and adsorption and then filtered into a preheated gas cell. Analysis was conducted for $\mathrm{CO}, \mathrm{CO}_{2}, \mathrm{HCl}, \mathrm{HCN}, \mathrm{HF}, \mathrm{HBr}, \mathrm{SO}_{2}$, and $\mathrm{NOx}$.

As described above, for specific optical density measurement and gas analysis it was necessary to modify the ASTM E662-09 standard and follow the ISO 5659 standard for the furnace and pilot burner because of the nature of the present SRF resin material. However, these deviations are expected to have little impacts on the test results because both are in general similar test methods. 
Table 3.1. Standard Procedures Used by Southwest Research Institute

\begin{tabular}{|c|c|c|c|c|}
\hline Main Analysis/Property & $\begin{array}{c}\text { Test } \\
\text { Equipment(s) }\end{array}$ & $\begin{array}{c}\text { Standard Procedures used } \\
\text { by SwRI }\end{array}$ & $\begin{array}{l}\text { Deviation } \\
\text { from } \\
\text { Standard } \\
\text { Procedure? }\end{array}$ & $\begin{array}{l}\text { SWRI Report } \\
\text { No. }\end{array}$ \\
\hline $\begin{array}{l}\text { Flash ignition temperature } \\
\text { (FIT) and spontaneous } \\
\text { ignition temperature (SIT) }\end{array}$ & $\begin{array}{l}\text { Hot-air ignition } \\
\text { furnace }\end{array}$ & $\begin{array}{l}\text { ASTM D1929-96, Standard } \\
\text { Test Method for } \\
\text { Determining Ignition } \\
\text { Temperature of Plastics }\end{array}$ & No & R13295.12.008a \\
\hline 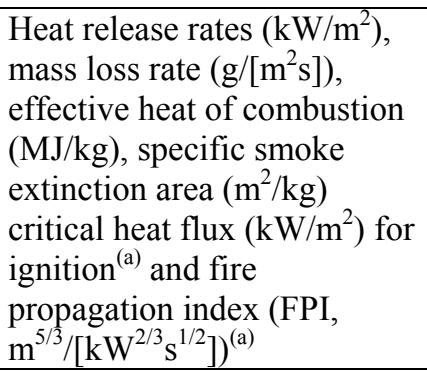 & $\begin{array}{l}\text { Cone } \\
\text { calorimeter } \\
\text { using oxygen } \\
\text { consumption } \\
\text { technique }\end{array}$ & $\begin{array}{l}\text { ASTM E1354-10, Standard } \\
\text { Test Method for Heat and } \\
\text { Visible Smoke Release Rates } \\
\text { for Materials and Products } \\
\text { Using an Oxygen } \\
\text { Consumption Calorimeter }\end{array}$ & No & $\begin{array}{l}\text { R13295.12.008b } \\
\text { R13295.12.008c }\end{array}$ \\
\hline $\begin{array}{l}\text { Heat release rate given by } \\
\text { maximum specific heat } \\
\text { release rate }\left(Q_{\max }, \mathrm{W} / \mathrm{g}\right) \text { and } \\
\text { effective heat of combustion } \\
\text { given by specific heat release } \\
\text { of sample }\left(h_{c}, \mathrm{~J} / \mathrm{g}\right)\end{array}$ & $\begin{array}{l}\text { Microscale } \\
\text { combustion } \\
\text { calorimeter } \\
\text { using oxygen } \\
\text { consumption } \\
\text { technique }\end{array}$ & $\begin{array}{l}\text { ASTM D7309-07A, } \\
\text { Standard Test Method for } \\
\text { Determining Flammability } \\
\text { Characteristics of Plastics } \\
\text { and Other Solid Materials } \\
\text { Using Microscale } \\
\text { Combustion Calorimetry }\end{array}$ & No & R13295.12.008d \\
\hline $\begin{array}{l}\text { Maximum specific optical } \\
\text { density }\left(D_{s} \text {, dimensionless), }\right. \\
\text { and maximum gas } \\
\text { concentrations (ppm) }\end{array}$ & $\begin{array}{l}\text { Radiant cone } \\
\text { heat furnace } \\
\text { Fourier } \\
\text { transform } \\
\text { infrared } \\
\text { spectrometer }\end{array}$ & $\begin{array}{l}\text { ASTM E662-09 }{ }^{(\mathrm{b})}, \text { Standard } \\
\text { Test Method for Specific } \\
\text { Optical Density of Smoke } \\
\text { Generated by Solid } \\
\text { Materials } \\
\text { ASTM E800-07 } \\
\text { Guide for Measurement of } \\
\text { Gases Present or Generated } \\
\text { During Fires }\end{array}$ & $\begin{array}{l}\text { Furnace }^{(\mathrm{c})} \\
\text { Pilot } \\
\text { burner }^{(\mathrm{d})} \\
\text { Pre-drying }\end{array}$ & R13295.12.008f \\
\hline $\begin{array}{l}\text { Particle size distribution of } \\
\text { generated smoke }\end{array}$ & $\begin{array}{l}\text { Radiant cone } \\
\text { heat furnace }\end{array}$ & Not applicable $^{(\mathrm{f})}$ & $\begin{array}{l}\text { Not } \\
\text { applicable }\end{array}$ & R13295.12.008e \\
\hline \multicolumn{5}{|c|}{$\begin{array}{l}\text { (b) In general accordance with the standard procedures. Any changes made in a standard testing procedure are } \\
\text { done to customize a test to the type of material being tested in unusual circumstances. These changes are done } \\
\text { in a manner that would not impact the results of a test in an unanticipated way. }\end{array}$} \\
\hline \multicolumn{5}{|c|}{$\begin{array}{l}\text { (c) } 5659 \text { furnace run in the horizontal orientation was used because the material could not sit in the sample } \\
\text { holder in a vertical orientation of the ASTM E662-09 furnace. }\end{array}$} \\
\hline \multicolumn{5}{|l|}{ (f) resuits. Ine $\angle$ to $1 \angle \mathrm{n} c$} \\
\hline
\end{tabular}





\subsection{Results and Discussion}

The results of the SRF resin fire tests reported by SwRI are summarized in this section. Where applicable, the precision and bias of each test method as given by each ASTM procedure are included. The precision and bias measures used in ASTM standards are defined as follows, per ASTM E177-10, Standard Practice for Use of the Terms Precision and Bias in ASTM Test Methods:

- precision: the closeness of agreement between independent test results obtained under stipulated conditions

- bias: the difference between the expectation of the test results and an accepted reference value

- repeatability: precision under repeatability conditions

- repeatability conditions: conditions where independent test results are obtained with the same method on identical test items in the same laboratory by the same operator using the same equipment within short intervals of time

- repeatability limit ( $r$ ): the value below which the absolute difference between two individual test results obtained under repeatability conditions may be expected to occur with a probability of approximately $0.95(95 \%)$

- reproducibility: precision under reproducibility conditions

- reproducibility conditions: conditions where test results are obtained with the same method on identical test items in different laboratories with different operators using different equipment

- reproducibility limit $(R)$ : the value below which the absolute difference between two test results obtained under reproducibility conditions may be expected to occur with a probability of approximately $0.95(95 \%)$.

\subsection{Flash Ignition Temperature and Spontaneous Ignition Temperature}

The results of FIT and SIT measurements of the SRF resin and negative and positive standards are summarized in Table 4.1. The negative test was performed on marinite, which is a non-combustible material and positive test was performed on poly methyl methacrylate (PMMA). Table 4.1 also includes the repeatability and reproducibility ranges determined from interlaboratory tests involving seven laboratories, on six polymeric materials, with triplicate tests of each material (ASTM D1929-96). The difference between two tests in this study $\left(10^{\circ} \mathrm{C}\right.$ for FIT and $5^{\circ} \mathrm{C}$ for SIT) is comparable to the repeatability limit for FIT and significantly smaller than the repeatability limit for SIT. It should be noted that the ASTM precision estimate is for the difference between averages determined from triplicate tests, whereas the difference reported in this study is based on one test per each run. Information on bias of this test method is not yet available. 
Table 4.1. Flash Ignition Temperature and Spontaneous Ignition Temperature of SRF Resin

\begin{tabular}{lcc}
\hline Property & FIT $\left({ }^{\circ} \mathrm{C}\right)$ & SIT $\left({ }^{\circ} \mathrm{C}\right)$ \\
\hline Initial Run & 600 & 615 \\
Duplicate Run & 590 & 610 \\
Average & 595 & 613 \\
Difference & 10 & 5 \\
& Precision estimates ${ }^{(\mathrm{a})}$ \\
$r$ & $8-13$ & $11-31$ \\
$R$ & $27-117$ & $47-103$
\end{tabular}

Negative and positive standards

$\begin{array}{llc}\text { Marinite (negative standard) } & \text { NM } & \text { No ignition } \\ \text { PMMA (positive standard) } & \text { NM } & 420\end{array}$

(a) Determined from interlaboratory tests involving seven laboratories on six polymeric materials with triplicate tests (ASTM D1929-96).

NM: not measured.

\subsection{Cone Calorimeter Results}

Table 4.2 shows the results of cone calorimeter tests on SRF resin and negative (marinite) and positive (PMMA) standards according to standard procedure ASTM E1354-10 for the following properties:

- peak heat release rate (HRRpeak, $\left.\mathrm{kW} / \mathrm{m}^{2}\right)$ : the maximum value of the heat release rate per unit sample area

- time to ignition $\left(t_{i g}, \mathrm{~s}\right)$ : time to ignition/sustained flaming (flame over specimen surface for at least $4 \mathrm{~s})$

- total heat release $\left(\mathrm{THR}, \mathrm{MJ} / \mathrm{m}^{2}\right)$ : total amount of heat released per unit sample area

- mass loss $\left(\mathrm{g} / \mathrm{m}^{2}\right)$ : total mass loss per unit sample area

- mass loss rate (MLR, $\left.\mathrm{g} /\left[\mathrm{m}^{2} \mathrm{~s}\right]\right)$ : average specimen mass loss rate per unit sample area computed over the test duration

- effective heat of combustion (EHC, $\mathrm{MJ} / \mathrm{kg}$ ): effective heat of combustion (the ratio of heat release rate to mass loss rate) averaged over the test duration or the entire test if ignition does not occur

- total smoke production $\left(S_{A}, \mathrm{~m}^{2} / \mathrm{m}^{2}\right)$ : total smoke production per unit sample area during the test duration

- smoke extinction area (SEA, $\mathrm{m}^{2} / \mathrm{kg}$ ): specific smoke extinction area (the ratio of smoke production to specimen mass loss) averaged over the test duration. 
Table 4.2. Results from Cone Calorimeter Tests of SRF Resin Performed at $100 \mathrm{~kW} / \mathrm{m}^{2}$ Heat Flux

\begin{tabular}{|c|c|c|c|c|c|c|}
\hline Property & $\begin{array}{l}\mathrm{HRR}_{\text {peak }} \\
\left(\mathrm{kW} / \mathrm{m}^{2}\right)\end{array}$ & $\begin{array}{l}t_{i g} \\
(\mathrm{~s})\end{array}$ & $\begin{array}{c}\text { THR } \\
\left(\mathrm{MJ} / \mathrm{m}^{2}\right)\end{array}$ & $\begin{array}{c}\text { Mass loss } \\
\left(\mathrm{g} / \mathrm{m}^{2}\right)\end{array}$ & $\begin{array}{c}\text { MLR } \\
\left(\mathrm{g} /\left[\mathrm{m}^{2} \mathrm{~s}\right]\right)\end{array}$ & $\begin{array}{c}\begin{array}{c}\mathrm{EHC} \\
(\mathrm{MJ} / \mathrm{kg})\end{array} \\
\end{array}$ \\
\hline Initial run $^{(\mathrm{a})}$ & 50 & 42 & 122.6 & 9810 & 2.7 & 12.5 \\
\hline Duplicate run $^{(\mathrm{a})}$ & 53 & 28 & 124.1 & 8782 & 2.5 & 14.1 \\
\hline Average & 51 & 35 & 123.4 & 9296 & 2.6 & 13.3 \\
\hline Difference & 3 & 14 & 1.5 & 1028 & 0.2 & 1.6 \\
\hline \multicolumn{7}{|c|}{ Precision estimates $^{(\mathrm{b})}$} \\
\hline$r$ & 20.0 & 8.5 & 15.8 & NA & NA & 1.9 \\
\hline$R$ & 67.7 & 15.1 & 22.7 & NA & NA & 3.2 \\
\hline \multicolumn{7}{|c|}{ Negative and positive standards ${ }^{(\mathrm{c})}$} \\
\hline Marinite (negative standard) & 5 & NI & 0.2 & 465 & 0.2 & 0.3 \\
\hline PMMA (positive standard) & 819 & 23 & 414.1 & 19131 & 30.7 & 21.6 \\
\hline
\end{tabular}

(a) Average of triplicate results.

(b) Based on interlaboratory tests involving six laboratories on six different materials (ASTM E1354-10).

(c) Tested at $50 \mathrm{~kW} / \mathrm{m}^{2}$ heat flux.

NA not available.

NI no ignition.

\begin{tabular}{|c|c|c|}
\hline Property & $S_{A}\left(\mathrm{~m}^{2} / \mathrm{m}^{2}\right)$ & SEA $\left(\mathrm{m}^{2} / \mathrm{kg}\right)$ \\
\hline Initial run $^{(\mathrm{a})}$ & 76 & 8 \\
\hline Duplicate run $^{(\mathrm{a})}$ & 159 & 18 \\
\hline Average & 118 & 13 \\
\hline Difference & 83 & 10 \\
\hline \multicolumn{3}{|c|}{ Precision estimates $^{(b)}$} \\
\hline$r$ & NA & 60.0 \\
\hline$R$ & NA & 65.8 \\
\hline \multicolumn{3}{|c|}{ Negative and positive standards ${ }^{(\mathrm{c})}$} \\
\hline Marinite (negative standard) & 42 & 91 \\
\hline PMMA (positive standard) & 1377 & 72 \\
\hline \multicolumn{3}{|c|}{$\begin{array}{l}\text { (a) Average of triplicate results. } \\
\text { (b) Based on interlaboratory tests involving six laboratories on six different } \\
\text { materials (ASTM E1354-10). } \\
\text { (c) Tested at } 50 \mathrm{~kW} / \mathrm{m}^{2} \text { heat flux. } \\
\text { NA not available. }\end{array}$} \\
\hline
\end{tabular}

Table 4.2 also includes the repeatability limit and reproducibility limit values related to the precision of the cone calorimeter test method. The ASTM E1354-10 procedure was conducted in interlaboratory trials involving six laboratories on six different materials. The $r$ and $R$ values were calculated from sample-based standard deviation estimates for repeatability $\left(s_{r}\right)$ and for reproducibility $\left(s_{R}\right)$ using the relations:

$$
\begin{aligned}
& r=2.8 s_{r} \\
& R=2.8 s_{R}
\end{aligned}
$$


The resulting $r$ or $R$ values then were used to fit linear regression models in the form

$$
y=a+b x
$$

where $y$ is $r$ or $R$ for each property, $x$ is the average of measured value for each property, and $a$ and $b$ are linear regression coefficients. The values for each property were calculated from the coefficient values given in ASTM E1354-10, and the average measured values in this study are given in Table 4.2.

The differences from duplicate tests in this study are, in general, comparable to or significantly smaller than the corresponding repeatability limits except for the time to ignition $\left(t_{i g}\right)$. The difference from duplicate tests for $t_{i g}(14 \mathrm{~s})$ in this study is larger than the repeatability limit $(8.5 \mathrm{~s})$, which is understandable considering the difference in the heat flux values used: this study used $100 \mathrm{~kW} / \mathrm{m}^{2}$ whereas the ASTM interlaboratory studies used 25 and $50 \mathrm{~kW} / \mathrm{m}^{2}$.

For an estimated bias, ASTM E1354-10 states that the use of the oxygen consumption technique results in an expected error band of $\pm 5 \%$ compared to the true value.

Additional tests were performed at varied heat fluxes from $40 \mathrm{~kW} / \mathrm{m}^{2}$ through $80 \mathrm{~kW} / \mathrm{m}^{2}$, in addition to the tests at $100 \mathrm{~kW} / \mathrm{m}^{2}$ summarized in Table 4.2 , to measure the surface temperature at ignition $\left(T_{i g}\right)$ needed to calculate the critical heat flux (CHF) using

$$
C H F=\frac{k_{c}}{\varepsilon}\left(T_{i g}-T_{\infty}\right)+\sigma\left(T_{i g}^{4}-T_{\infty}^{4}\right)
$$

where $k_{c}$ is convection coefficient $\left(0.012 \mathrm{~kW} /\left[\mathrm{m}^{2} \mathrm{~K}\right]\right), \varepsilon$ is surface emissivity (estimated at 0.9$), T_{i g}$ is surface temperature at ignition $(\mathrm{K}), T_{\infty}$ is ambient temperature $(293 \mathrm{~K})$, and $\sigma$ is Stefan-Boltzmann constant $\left(5.67 \times 10^{-11} \mathrm{~kW} /\left[\mathrm{m}^{2} \mathrm{~K}^{4}\right]\right)$. The average value of $T_{i g}$, along with extrapolated and bracketed CHF values are summarized in Table 4.3.

Table 4.3. Average Surface Temperature at Ignition and Extrapolated and Bracketed Critical Heat Flux for Ignition

\begin{tabular}{ccc}
\hline $\begin{array}{c}\text { Average Surface } \\
\text { Temperature at } \\
\text { Ignition, } T_{i g}(\mathrm{~K})\end{array}$ & $\begin{array}{c}\text { CHF for Ignition - } \\
\text { Extrapolated } \\
\left(\mathrm{kW} / \mathrm{m}^{2}\right)\end{array}$ & $\begin{array}{c}\text { CHF for Ignition - } \\
\text { Bracketed }\left(\mathrm{kW} / \mathrm{m}^{2}\right)\end{array}$ \\
\hline 873 & 40.3 & 42.0 \\
\hline
\end{tabular}

The $t_{i g}$ values were also obtained from tests at varied heat fluxes from $40 \mathrm{~kW} / \mathrm{m}^{2}$ through $100 \mathrm{~kW} / \mathrm{m}^{2}$. Figure 4.1 shows the plot of $t_{i g}^{-1 / 2}$ versus external heat flux, which was used to calculate the thermal response parameter (TRP). The TRP is a measure of the thermal inertia of a material (product of thermal conductivity, density, and specific heat). It is defined as the inverse of the slope of the linear fit obtained from the $t_{i g}^{-1 / 2}$ versus external heat flux data, which is given as $465 \pm 22 \mathrm{kWs} \mathrm{s}^{1 / 2} / \mathrm{m}^{2}$ in Figure 4.1 . 


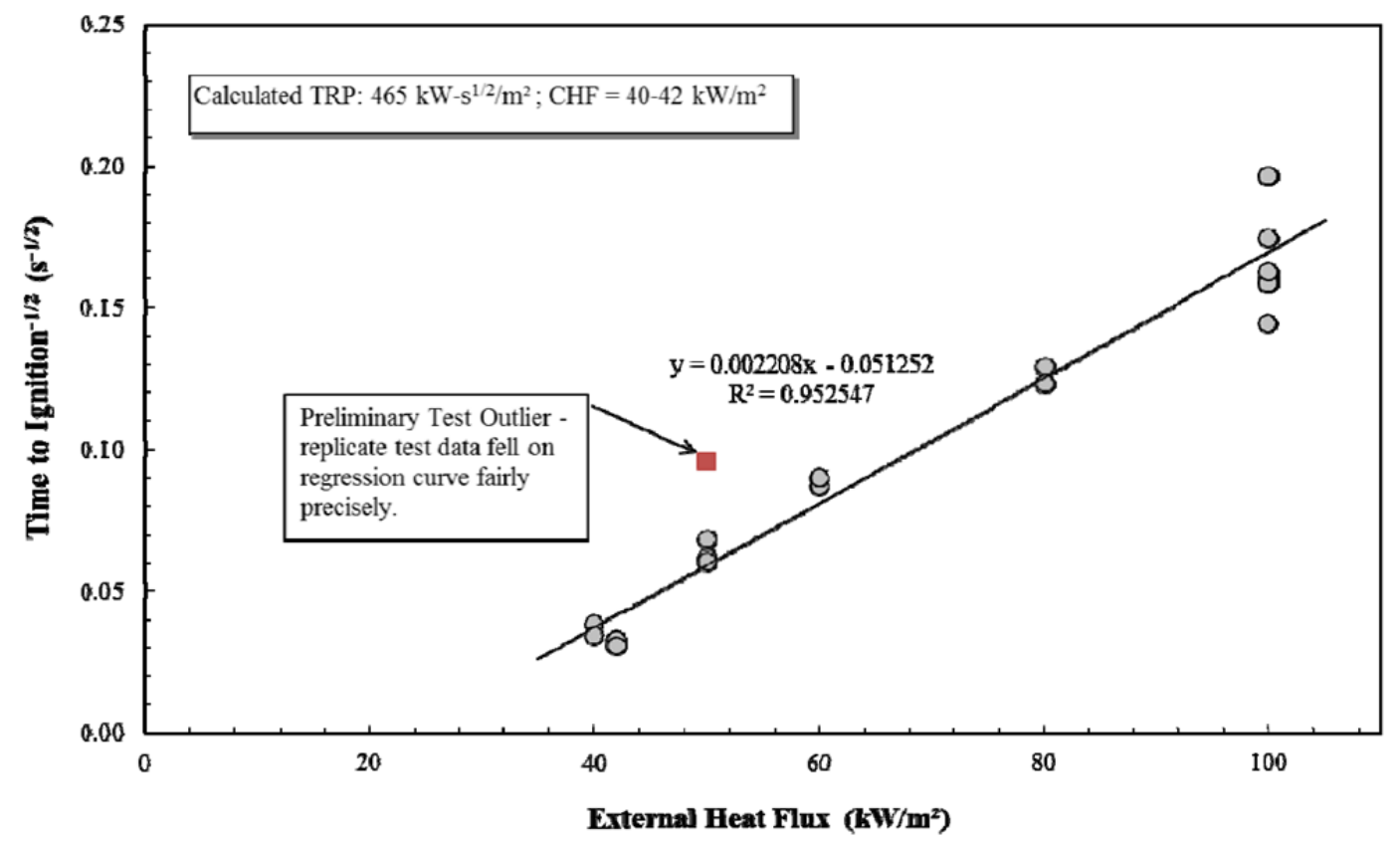

Figure 4.1. Time to Ignition as a Function of External Heat Flux to Determine the TRP (from SwRI report for R13295.12.008c)

The fire propagation index (FPI) is a measure of full-scale flame spread propensity and is calculated based on the TRP and peak HRR data. Typically, the FPI is computed with peak HRR measured at $50 \mathrm{~kW} / \mathrm{m}^{2}$ exposure irradiance of the test specimen. However, because the WTP was interested in HRR data at a heat flux of $100 \mathrm{~kW} / \mathrm{m}^{2}$, values of FPI were calculated for both heat fluxes and reported in Table 4.4. Along with the HRR and additional data obtained from tests at $50 \mathrm{~kW} / \mathrm{m}^{2}$, the FPI is calculated from

$$
F P I=\frac{1000\left(0.042 H R R_{\text {peak }}\right)^{1 / 3}}{T R P}
$$

Table 4.4. Summary of Cone Calorimeter Test Results and Calculated Fire Propagation Index (FPI) at 50 and $100 \mathrm{~kW} / \mathrm{m}^{2}$

\begin{tabular}{lccccc}
\hline Heat Flux & $\begin{array}{c}\text { HRRpeak } \\
\left(\mathrm{kW} / \mathrm{m}^{2}\right)\end{array}$ & $\begin{array}{c}\text { THR } \\
\left(\mathrm{MJ} / \mathrm{m}^{2}\right)\end{array}$ & $\begin{array}{c}\text { EHC } \\
(\mathrm{MJ} / \mathrm{kg})\end{array}$ & $\begin{array}{c}\mathrm{SEA} \\
\left(\mathrm{m}^{2} / \mathrm{kg}\right)\end{array}$ & $\begin{array}{c}\text { FPI } \\
\mathrm{m}^{5 / 3} /\left[\mathrm{kW}^{2 / 3} \mathrm{~s}^{1 / 2}\right]\end{array}$ \\
\hline $50 \mathrm{~kW} / \mathrm{m}^{2(\mathrm{a})}$ & 44 & 116 & $13.7^{(\mathrm{b})}$ & $8.0^{(\mathrm{c})}$ & 2.64 \\
$100 \mathrm{~kW} / \mathrm{m}^{2(\mathrm{~d})}$ & 51 & 123 & 13.3 & $12.5^{(\mathrm{e})}$ & 2.77 \\
\hline $\begin{array}{l}\text { (a) } \\
\text { (b) Average of triplicate test results. }\end{array}$ & \\
(c) Average EHC for two of three runs was $12.2 \mathrm{MJ} / \mathrm{kg}$ (one run was $16.7 \mathrm{MJ} / \mathrm{kg}$, which skews the \\
(d) Average SEA for two of three runs was $1.5 \mathrm{~m}^{2} / \mathrm{kg}$ (one run was $22 \mathrm{~m}^{2} / \mathrm{kg}$, which skews the average). \\
(e) There is a fair amount of scatter in this measured parameter, likely due to exactly how a given batch of \\
samples was dried prior to testing.
\end{tabular}




\subsection{Microscale Calorimeter Results}

Table 4.5 shows the results of flammability characteristics following the standard procedure ASTM D7309-07A Method A between $75^{\circ} \mathrm{C}$ and $750^{\circ} \mathrm{C}$ at a heating rate of $1 \mathrm{~K} / \mathrm{s}$. The negative test was performed on silver and positive test was performed on PMMA. In Table 4.5, results are listed for the following properties:

- maximum specific heat release rate $\left(Q_{\max }, \mathrm{W} / \mathrm{g}\right)$ : the maximum value of the specific heat release rate recorded during the test

- heat release temperature $\left(T_{\max },{ }^{\circ} \mathrm{C}\right)$ : the specimen temperature at which the specific heat release rate is a maximum during controlled thermal decomposition

- heat release capacity $(\eta, \mathrm{J} /[\mathrm{gK}])$ : the maximum specific heat release rate during controlled thermal decomposition divided by the heating rate of the test

- specific heat release $\left(h_{\mathrm{c}}, \mathrm{J} / \mathrm{g}\right)$ : the net heat of complete combustion of the volatiles liberated during controlled thermal decomposition per unit initial specimen mass

- pyrolysis residue $\left(Y_{p}, \mathrm{~g} / \mathrm{g}\right)$ : the fraction of the initial specimen mass remaining after controlled anaerobic thermal decomposition (Method A only)

- specific heat of combustion for specimen gases $\left(h_{c, g a s}, \mathrm{~J} / \mathrm{g}\right)$ : the net heat of complete combustion of the volatiles liberated during controlled thermal decomposition per unit mass of volatiles, i.e., $h_{c, g a s}=h_{c} /\left(1-Y_{p}\right)$.

Table 4.5also includes the repeatability limit and reproducibility limit values related to the precision of the microscale calorimeter test method based on interlaboratory trials involving twelve laboratories on five different solid materials.

The differences from duplicate tests in this study are, in general, comparable to or significantly smaller than the corresponding repeatability limits except for the heat release temperature $\left(T_{\max }\right)$. The large difference for $T_{\max }\left(14^{\circ} \mathrm{C}\right)$ compared to the repeatability limit $\left(5.1-6.6^{\circ} \mathrm{C}\right)$ is likely due to the characteristics of the present SRF resin material different from those common materials used in the interlaboratory studies. 
Table 4.5. Micro-Calorimeter Test Results of SRF Resin, Method A, $75-750^{\circ} \mathrm{C}, 1 \mathrm{~K} / \mathrm{s}$

\begin{tabular}{|c|c|c|c|c|c|c|}
\hline Property & $Q_{\max }(\mathrm{W} / \mathrm{g})$ & $T_{\max }\left({ }^{\circ} \mathrm{C}\right)$ & $\eta(\mathrm{J} /[\mathrm{gK}])$ & $h_{c}(\mathrm{~kJ} / \mathrm{g})$ & $Y_{p}(\mathrm{~g} / \mathrm{g})$ & $\begin{array}{c}h_{c, g a s} \\
(\mathrm{~kJ} / \mathrm{g})\end{array}$ \\
\hline Initial run $^{(\mathrm{a})}$ & 22.4 & 641 & 22.4 & 5.171 & 0.5754 & 12.296 \\
\hline Duplicate run $^{(\mathrm{a})}$ & 20.8 & 655 & 20.8 & 4.237 & 0.5853 & 10.139 \\
\hline Average & 21.6 & 648 & 21.6 & 4.704 & 0.5804 & 11.218 \\
\hline Difference & 1.6 & 14 & 1.6 & 0.934 & 0.0099 & 2.157 \\
\hline \multicolumn{7}{|c|}{ Precision estimates ${ }^{(b)}$} \\
\hline$r$ & $18.5-70.0$ & $5.1-6.6$ & $20.8-91.0$ & $0.6-2.3$ & $0.0053-0.0380$ & NA \\
\hline$R$ & $53.3-250.1$ & $23.0-42.3$ & $50.5-242.0$ & $2.8-6.4$ & $0.0091-0.0712$ & NA \\
\hline \multicolumn{7}{|c|}{ Negative and positive standards } \\
\hline Silver (negative standard) & 9.7 & 1010 & 9.7 & 3.350 & 1 & 0 \\
\hline PMMA (positive standard) & 383.8 & 674 & 383.8 & 27.653 & 0 & 27.653 \\
\hline $\begin{array}{l}\text { (a) Average of triplicate resul } \\
\text { (b) Based on interlaboratory t } \\
\text { NA not available. }\end{array}$ & ts involving & laborator & five differ & id mate & (ASTM D7309- & \\
\hline
\end{tabular}

The results of the similar tests performed per ASTM D7309-07A Method B are summarized in Table 4.6. The $\eta$ value is the same as $Q_{\max }$ because the heating rate used in all tests was $1 \mathrm{~K} / \mathrm{s}$ for both Methods A and B. For Method B, the test measures net heat of combustion of both the specimen gases and solid residue, i.e., $Y_{p}=0$, and therefore $h_{c, \text { gas }}=h_{c}$. The precision data for Method B were not available. There was no statement on the bias for the ASTM D7309-07A method.

Table 4.6. Micro-Calorimeter Test Results of SRF Resin, Method B, $75-750^{\circ} \mathrm{C}, 1 \mathrm{~K} / \mathrm{s}$

\begin{tabular}{lcccc}
\hline Property & $Q_{\max }(\mathrm{W} / \mathrm{g})$ & $T_{\max }\left({ }^{\circ} \mathrm{C}\right)$ & $\eta(\mathrm{J} /[\mathrm{gK}])$ & $h_{c}(\mathrm{~kJ} / \mathrm{g})$ \\
\hline Initial run $^{\text {(a) }}$ & 127.6 & 566 & 127.6 & 13.374 \\
Duplicate run $^{\text {(a) }}$ & 121.5 & 568 & 121.5 & 12.703 \\
Average & 124.6 & 567 & 124.6 & 13.039 \\
Difference & 6.1 & 2 & 6.1 & 0.671 \\
\hline
\end{tabular}

(a) Average of triplicate results.

\subsection{Smoke Particle Size and Specific Optical Density}

Figure 4.2 and Figure 4.3 show the particle size distribution of smoke generated from the tests performed under nonflaming condition and under flaming condition, respectively. The median diameter $\left(d_{50}\right)$ was $2.4 \mu \mathrm{m}$ under nonflaming condition and $4.0 \mu \mathrm{m}$ (average from duplicate tests) under flaming condition. Under nonflaming condition, the largest particle was $7.2 \mu \mathrm{m}$ and about $1.5 \%$ of the particles were smaller than $0.52 \mu \mathrm{m}$. Under flaming condition, the largest particle was $11.1 \mu \mathrm{m}$ and only about $0.3 \%$ of the particles were smaller than $0.52 \mu \mathrm{m}$. 


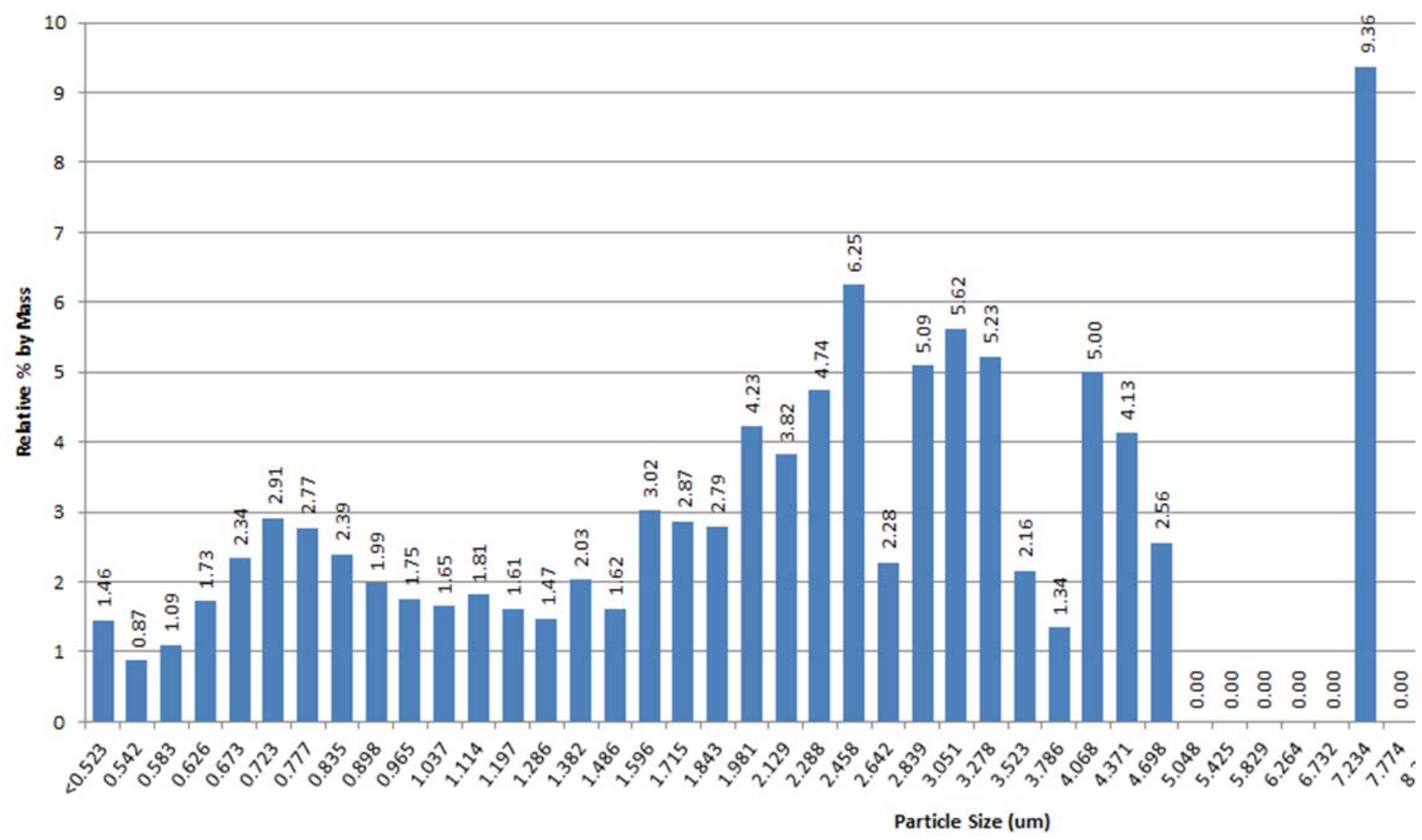

Figure 4.2. Smoke Particle Size Distribution of SRF Resin Under Nonflaming Condition

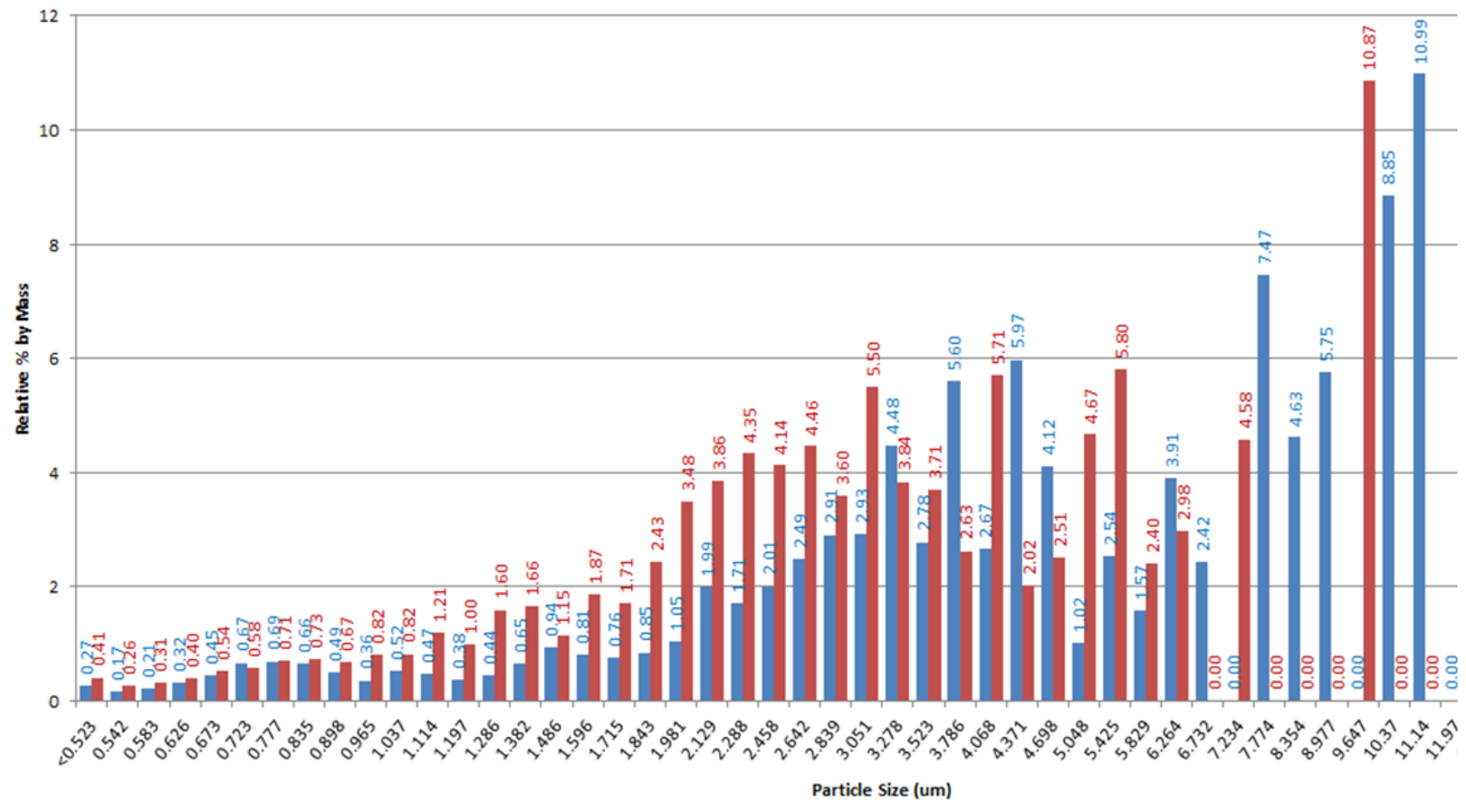

Figure 4.3. Smoke Particle Size Distribution of SRF Resin Under Flaming Condition (blue = initial test, red $=$ duplicate test)

Figure 4.4 and Figure 4.5 show the particle size distribution of smoke generated from the negative standard (calcium silicate) and positive standard (Schneller core), respectively. The $d_{50}$ was $3.2 \mu \mathrm{m}$ for negative standard and $1.8 \mu \mathrm{m}$ for positive standard. 


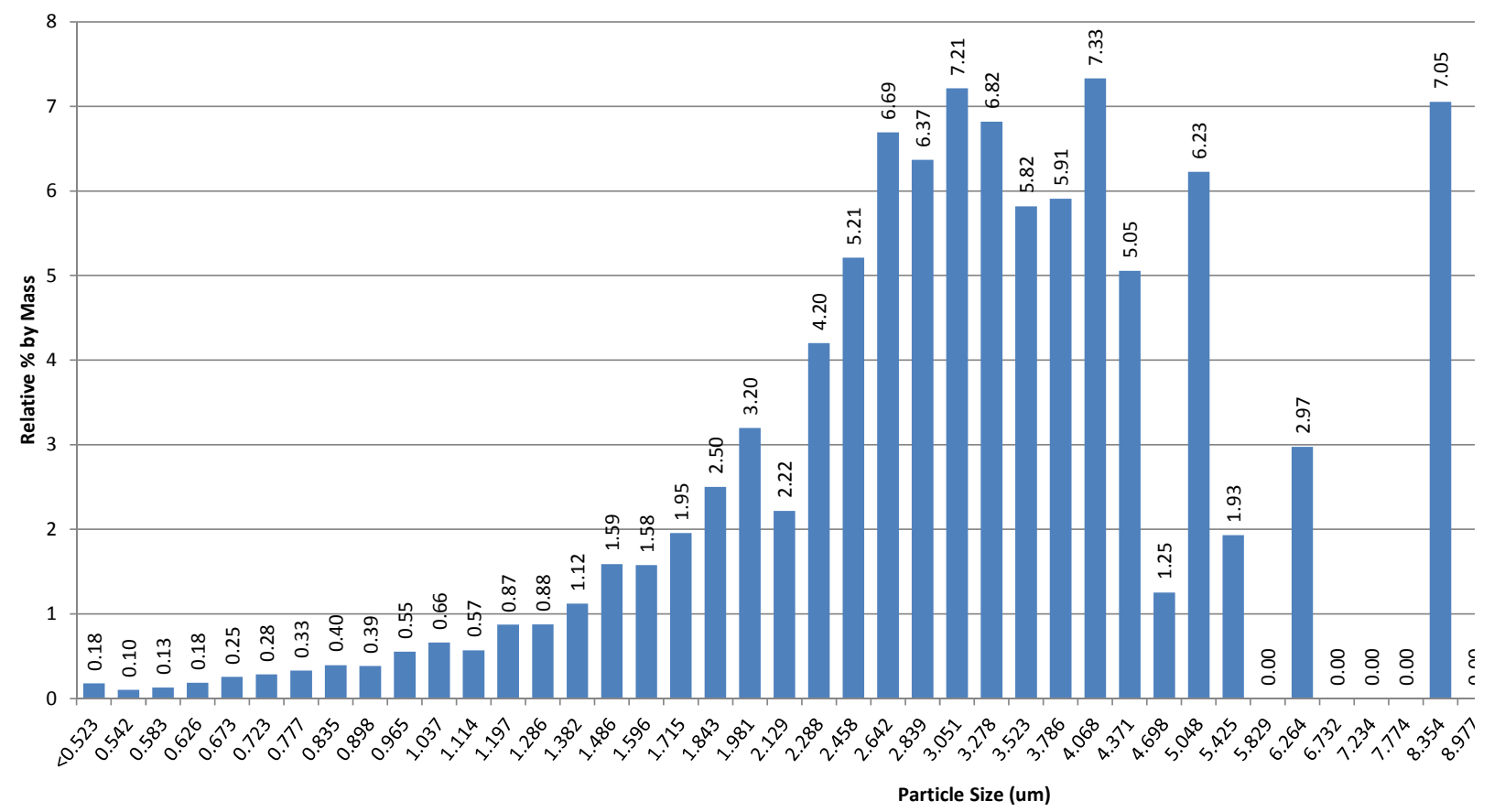

Figure 4.4. Smoke Particle Size Distribution of Negative Standard Under Nonflaming Condition

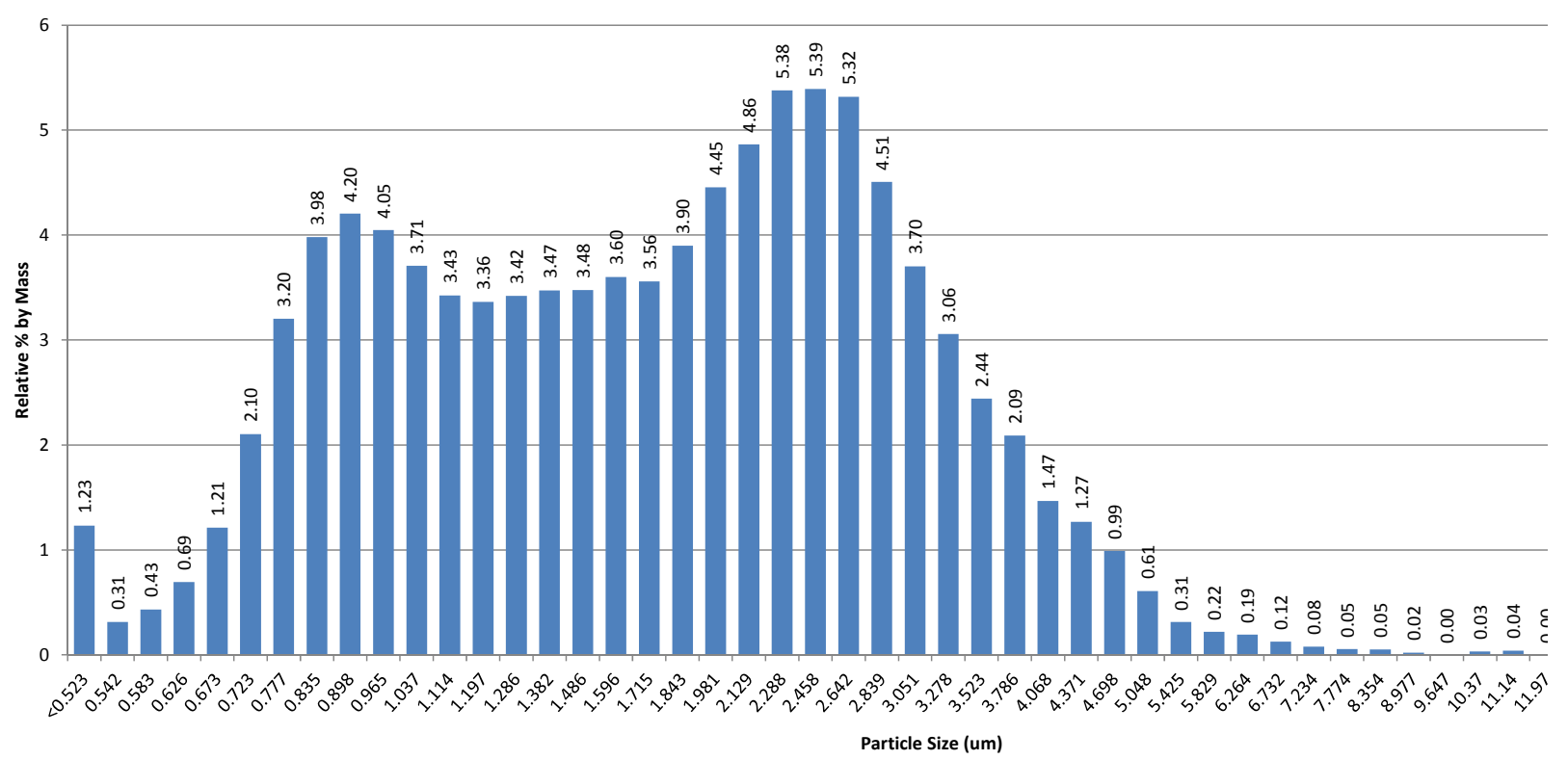

Figure 4.5. Smoke Particle Size Distribution of Positive Standard Under Flaming Condition

Table 4.7 summarizes the results for specific optical density of smoke $\left(D_{s}\right)$ determined in general accordance with standard procedure ASTM E662-09 but with some deviations as described in Section 3.5. The negative test was performed on calcium silicate, which is non-combustible material and positive tests were performed on $\alpha$-cellulose material under the nonflaming condition and on Schneller core panel under the flaming condition. The results from negative and positive tests are given in Table 4.7. Table 4.7 also includes the precision estimates obtained from interlaboratory trials. For standard procedure ASTM E662-09, the precision estimates are given as relative $r$ and $R$ calculated by 
dividing the $r$ and $R$ by average optical density, which need to be compared with relative difference that is also included in Table 4.7. The difference from duplicate runs in this study is generally comparable to the relative repeatability limits although there were deviations from the ASTM standards as described in Section 3.5. Standard procedure ASTM E662-09 states that the bias of this test method is unknown because the value of specific optical density obtained in this procedure is defined only in terms of this test method.

The maximum gas concentrations measured using an FTIR spectrometer are in Table 4.8. The other gases that were also measured- $\mathrm{HCl}, \mathrm{HCN}, \mathrm{HF}, \mathrm{HBr}$, and $\mathrm{NOx}-$ were not detected in the SRF resin sample. Table 4.8 also includes maximum gas concentration results from negative and positive tests. There are large differences in $\mathrm{CO}$ and $\mathrm{CO}_{2}$ concentrations between duplicate results. SwRI performed careful review of the raw data files to investigate the potential cause of these large differences and did not find any indication that the tests were done incorrectly. It is suspected that the large differences are likely due to the characteristics inherent to the present SRF resin material.

Table 4.7. Maximum Specific Optical Density $\left(D_{s}\right)$

\begin{tabular}{|c|c|c|c|c|}
\hline \multirow[b]{2}{*}{ Test Run } & \multicolumn{2}{|c|}{ Flaming Condition } & \multicolumn{2}{|c|}{ Nonflaming Condition } \\
\hline & Maximum $D_{s}$ & $\begin{array}{c}\text { Maximum } D_{s} \\
\text { (corrected) }\end{array}$ & Maximum $D_{s}$ & $\begin{array}{l}\text { Maximum } D_{s} \\
\text { (corrected) }\end{array}$ \\
\hline Initial run $^{(a)}$ & 0.60 & 0.56 & 0.44 & 0.30 \\
\hline Duplicate run $^{(\mathrm{a})}$ & 0.70 & 0.41 & 0.26 & 0.21 \\
\hline Average & 0.65 & 0.49 & 0.35 & 0.26 \\
\hline Difference & 0.10 & 0.15 & 0.18 & 0.09 \\
\hline Relative difference & $15.4 \%$ & $30.9 \%$ & $51.4 \%$ & $35.3 \%$ \\
\hline \multicolumn{5}{|c|}{ Precision estimates $^{(b)}$} \\
\hline Relative $r$ & $5.7 \%-47.5 \%$ & NA & $5.0 \%-51.4 \%$ & NA \\
\hline Relative $R$ & $23.0 \%-117.7 \%$ & NA & $16.0 \%-91.5 \%$ & NA \\
\hline \multicolumn{5}{|c|}{ Negative and positive standards } \\
\hline Calcium silicate (negative standard) & 0.50 & 0.50 & 0.47 & 0.00 \\
\hline$\alpha$-cellulose (positive standard) & NM & NM & 178.69 & 150.14 \\
\hline Schneller core (positive standard) & 107.65 & 91.98 & NM & NM \\
\hline $\begin{array}{l}\text { (a) Average of triplicate results. } \\
\text { (b) Based on interlaboratory tests (AST) } \\
\text { NA not available. } \\
\text { NM not measured. }\end{array}$ & E662-09). & & & \\
\hline
\end{tabular}


Table 4.8. Maximum Gas Concentrations

\begin{tabular}{|c|c|c|c|c|}
\hline Exposure Mode & $\mathrm{CO}(\mathrm{ppm})$ & $\mathrm{CO}_{2}(\mathrm{ppm})$ & $\mathrm{SO}_{2}(\mathrm{ppm})$ & $\mathrm{HCN}(\mathrm{ppm})$ \\
\hline Nonflaming & $803 \pm 6$ & $834 \pm 41$ & $3 \pm 1$ & ND \\
\hline Flaming & $1681 \pm 18$ & $1628 \pm 63$ & $7 \pm 2$ & ND \\
\hline Nonflaming, duplicate & $88 \pm 1$ & $3421 \pm 123$ & $2.3 \pm 1.5$ & ND \\
\hline Flaming, duplicate & $762 \pm 55$ & $1057 \pm 43$ & $7 \pm 3$ & ND \\
\hline \multicolumn{5}{|c|}{ Negative and positive standards } \\
\hline negative, nonflaming & ND & $116 \pm 21$ & ND & ND \\
\hline negative, flaming & ND & $1113 \pm 38$ & ND & $10 \pm 2$ \\
\hline positive, nonflaming & $332 \pm 2$ & $820 \pm 37$ & $3 \pm 1$ & ND \\
\hline positive, flaming & $20 \pm 1$ & $501 \pm 7$ & ND & ND \\
\hline
\end{tabular}

\subsection{Discussion on Smoke Data}

Smoke is defined as the airborne solid and liquid particulates and gases evolved when a material undergoes pyrolysis or combustion (ASTM E176-10). The property most widely used to characterize the smoke is the light extinction coefficient. The physical basis for light extinction measurements is Bouguer's law (also known Lambert's law) (Mulholland 1995):

$$
\frac{I}{I^{0}}=e^{-K L}
$$

where $I^{0}$ is intensity of the incident light, $I$ is the intensity of the light transmitted through the smoke, $L$ is the light path length (m), and $K$ is the light extinction coefficient $\left(\mathrm{m}^{-1}\right)$.

Per ASTM E662-09 standard, the specific optical density, $D_{s}$ (dimensionless), is calculated by the equation:

$$
D_{s}=\frac{V}{A L} \log _{10}\left(\frac{I^{0}}{I}\right)=\frac{K V}{2.303 A}
$$

where $V$ is the volume of test chamber $\left(\mathrm{m}^{3}\right)$ and $A$ is the exposed area of test sample $\left(\mathrm{m}^{2}\right)$. The $D_{s}$ represents the amount of visible smoke accumulated in a test chamber measured over unit path length within a chamber of unit volume produced from a sample of unit surface area. When the mass loss of the sample is measured, the mass optical density, $D_{m}$, is the appropriate measure of visible smoke:

$$
D_{m}=\frac{D_{s} A}{\Delta m}
$$

where $\Delta m$ is the mass loss $(\mathrm{kg})$. Table 4.9 summarizes the maximum $D_{s}$ (from Table 4.7 , average value for SRF resin), the mass loss, and resulting maximum mass optical density values of the SRF resin compared with those of the negative and positive standard materials. Table 4.9 shows that the SRF resin has the maximum $D_{s}$ and $D_{m}$ comparable to or lower than the negative standard, calcium silicate, which is a non-combustible material. 
Table 4.9. Maximum Mass Optical Density $\left(D_{m}\right)$

\begin{tabular}{lcccccc}
\hline \multirow{2}{*}{ Material } & \multicolumn{3}{c}{ Flaming Condition } & \multicolumn{3}{c}{ Nonflaming Condition } \\
\cline { 2 - 7 } & $\begin{array}{c}\text { Max } D_{s} \\
(\text { corrected) }\end{array}$ & $\begin{array}{c}\text { Mass } \\
\text { loss }(\mathrm{g})\end{array}$ & $\begin{array}{c}\text { Max } D_{m} \\
\left(\mathrm{~m}^{2} / \mathrm{kg}\right)\end{array}$ & $\begin{array}{c}\text { Max } D_{s} \\
(\text { corrected })\end{array}$ & $\begin{array}{c}\text { Mass } \\
\operatorname{loss}(\mathrm{g})\end{array}$ & $\begin{array}{c}\text { Max } D_{m} \\
\left(\mathrm{~m}^{2} / \mathrm{kg}\right)\end{array}$ \\
\hline SRF resin & 0.49 & 17.54 & 0.12 & 0.26 & 17.73 & 0.06 \\
Calcium silicate (negative standard) & 0.50 & 1.80 & 1.18 & 0.00 & 2.00 & 0.00 \\
a-cellulose (positive standard) & $\mathrm{NM}$ & $\mathrm{NM}$ & $\mathrm{NM}$ & 150.1 & 3.20 & 198.8 \\
Schneller core (positive standard) & 91.98 & 3.26 & 119.6 & $\mathrm{NM}$ & $\mathrm{NM}$ & $\mathrm{NM}$ \\
\hline NM not measured. & & & & & & \\
\hline
\end{tabular}

The smoke data from cone calorimetry per ASTM E1354-10 standard are also obtained from the light extinction measurements based on Equation (6). However, the cone calorimetry is a dynamic test method that measures the smoke in the flowing exhaust generated at 50 or $100 \mathrm{~kW} / \mathrm{m}^{2}$ heat flux compared to the static method of ASTM E662-09 standard that measures the smoke accumulated in a closed system (smoke chamber) generated at $25 \mathrm{~kW} / \mathrm{m}^{2}$ heat flux. Per ASTM E1354-10 standard, the total smoke production per unit sample area, $S_{A},\left(\mathrm{~m}^{2} / \mathrm{m}^{2}\right)$ is calculated by:

$$
S_{A}=\frac{K \dot{V} t_{T}}{A}=\frac{\dot{V} t_{T}}{A L} \ln \left(\frac{I^{0}}{I}\right)
$$

where $\dot{V}$ is the volume flow rate of exhaust at the location of the light extinction measurement $\left(\mathrm{m}^{3} / \mathrm{s}\right)$ and $t_{T}$ is the total test duration. Then, the specific extinction area, SEA $\left(\mathrm{kg} / \mathrm{m}^{2}\right)$, is calculated by:

$$
\mathrm{SEA}=\frac{S_{A}}{\Delta m_{s}}
$$

where $\Delta m_{s}$ is the mass loss per unit sample surface area $\left(\mathrm{kg} / \mathrm{m}^{2}\right)$. The SEA is a measure of the instantaneous amount of smoke being produced per unit mass of sample burnt, which is equivalent to the $D_{m}$ from the smoke chamber test, although they are obtained under different test conditions mentioned above. As was summarized in Table 4.2, the total smoke production $\left(S_{A}\right)$ of SRF resin is slightly larger but the SEA of SRF resin is significantly smaller than the negative standard, marinite board, which is also a non-combustible material.

Table 4.10 summarizes the $d_{50}$ and estimated concentration of smoke used in particle size distribution for the SRF resin compared with those for the negative and positive standard materials. Table 4.10 also notes that the estimated concentrations for the SRF resin and negative standard material are indistinguishable from background, which supports the results obtained from light extinction measurements discussed above. 
Table 4.10. Summary of Particle Size Distribution Measurement Results

\begin{tabular}{lccr}
\hline \multicolumn{1}{c}{ Material } & $d_{50}$, & $\begin{array}{c}\text { Estimated } \\
\text { concentration, } \\
\mu \mathrm{g} / \mathrm{m}^{3}\end{array}$ & Note \\
\hline SRF resin, flaming & 4.0 & 10.9 & indistinguishable from background \\
SRF resin, nonflaming & 2.4 & 4.2 & indistinguishable from background \\
Calcium silicate (negative standard), flaming & 3.2 & 8.7 & indistinguishable from background \\
Schneller core (positive standard), flaming & 1.8 & 3589 & \\
\hline
\end{tabular}





\subsection{Summary}

Table 5.1 summarizes the mean, difference, and repeatability limit presented in Section 4. The differences from duplicate tests in this study are, in general, comparable to or significantly smaller than the corresponding repeatability limits, suggesting general satisfactory precision of the test results. Exceptions were noted for the time to ignition ( $t_{i g}$, ASTM E1354-10) and heat release temperature $\left(T_{\max }\right.$, ASTM D7309-07A) of which potential explanations were provided in Section 4.

Table 5.1. Summary of Fire Test Results on SRF Resin

\begin{tabular}{|c|c|c|c|c|}
\hline $\begin{array}{l}\text { ASTM } \\
\text { Procedure }\end{array}$ & Analysis/Property & Mean & Difference & $\begin{array}{l}\text { Repeatability } \\
\text { Limit }\end{array}$ \\
\hline \multirow{2}{*}{$\begin{array}{l}\text { ASTM } \\
\text { D1929-96 }\end{array}$} & Flash ignition temperature, FIT $\left({ }^{\circ} \mathrm{C}\right)$ & 595 & 10 & $8-13$ \\
\hline & Spontaneous ignition temperature, $\operatorname{SIT}\left({ }^{\circ} \mathrm{C}\right)$ & 613 & 5 & $11-31$ \\
\hline \multirow{12}{*}{$\begin{array}{l}\text { ASTM } \\
\text { E1354-10 }\end{array}$} & Heat release rate, $\mathrm{HRR}_{\text {peak }}\left(\mathrm{kW} / \mathrm{m}^{2}\right)$ & 51 & 3 & 20.0 \\
\hline & Time to ignition, $t_{i g}(\mathrm{~s})$ & 35 & 14 & 8.5 \\
\hline & Total heat release, THR $\left(\mathrm{MJ} / \mathrm{m}^{2}\right)$ & 123.4 & 1.5 & 15.8 \\
\hline & Mass loss $\left(\mathrm{g} / \mathrm{m}^{2}\right)$ & 9296 & 1028 & NA \\
\hline & Mass loss rate, MLR (g/[m² s]) & 2.6 & 0.2 & NA \\
\hline & Effective heat of combustion, EHC (MJ/kg) & 13.3 & 1.6 & 1.9 \\
\hline & Total smoke production, $S_{A}\left(\mathrm{~m}^{2} / \mathrm{m}^{2}\right)$ & 118 & 83 & NA \\
\hline & Specific smoke extinction area, SEA $\left(\mathrm{m}^{2} / \mathrm{kg}\right)$ & 13 & 10 & 60.0 \\
\hline & Critical heat flux for ignition - extrapolated $\left(\mathrm{kW} / \mathrm{m}^{2}\right)$ & 40.3 & -- & NA \\
\hline & Critical heat flux for ignition -bracketed $\left(\mathrm{kW} / \mathrm{m}^{2}\right)$ & 42.0 & -- & NA \\
\hline & FPI $\left(\mathrm{m}^{5 / 3} /\left[\mathrm{kW}^{2 / 3} \mathrm{~s}^{1 / 2}\right]\right)$ at $50 \mathrm{~kW} / \mathrm{m}^{2}$ & 2.64 & -- & NA \\
\hline & FPI $\left(\mathrm{m}^{5 / 3} /\left[\mathrm{kW}^{2 / 3} \mathrm{~s}^{1 / 2}\right]\right)$ at $100 \mathrm{~kW} / \mathrm{m}^{2}$ & 2.77 & -- & NA \\
\hline \multirow{6}{*}{$\begin{array}{l}\text { ASTM } \\
\text { D7309-07A, } \\
\text { Method A }\end{array}$} & Maximum specific heat release rate, $Q_{\max }(\mathrm{W} / \mathrm{g})$ & 21.6 & 1.6 & $18.5-70.0$ \\
\hline & Heat release temperature, $T_{\max }\left({ }^{\circ} \mathrm{C}\right)$ & 648 & 14 & $5.1-6.6$ \\
\hline & Heat release capacity, $\eta(\mathrm{J} / \mathrm{gK})$ & 21.6 & 1.6 & $20.8-91.0$ \\
\hline & Specific heat release, $h_{c}(\mathrm{~kJ} / \mathrm{g})$ & 4.704 & 0.934 & $0.6-2.3$ \\
\hline & Pyrolysis residue, $Y_{p}(\mathrm{~g} / \mathrm{g})$ & 0.5804 & 0.0099 & $0.0053-0.0380$ \\
\hline & Specific heat of combustion, $h_{c, \text { gas }}(\mathrm{kJ} / \mathrm{g})$ & 11.218 & 2.157 & NA \\
\hline \multirow{4}{*}{$\begin{array}{l}\text { ASTM } \\
\text { D7309-07A, } \\
\text { Method B }\end{array}$} & Maximum specific heat release rate, $Q_{\max }(\mathrm{W} / \mathrm{g})$ & 124.6 & 6.1 & NA \\
\hline & Heat release temperature, $T_{\max }\left({ }^{\circ} \mathrm{C}\right)$ & 567 & 2 & NA \\
\hline & Heat release capacity, $\eta(\mathrm{J} / \mathrm{gK})$ & 124.6 & 6.1 & NA \\
\hline & Specific heat release, $h_{c}(\mathrm{~kJ} / \mathrm{g})$ & 13.039 & 0.671 & NA \\
\hline \multirow{4}{*}{$\begin{array}{l}\text { ASTM } \\
\text { E662-09 }\end{array}$} & Maximum specific optical density, $D_{s}$ (flaming) & 0.65 & 0.10 & $0.04-0.31^{(b)}$ \\
\hline & $\begin{array}{l}\text { Corrected maximum specific optical density, } \\
D_{s}(\text { corr }) \text { (flaming) }\end{array}$ & 0.49 & 0.15 & NA \\
\hline & Maximum specific optical density, $D_{s}$ (nonflaming) & 0.35 & 0.18 & $0.02-0.18^{(\mathrm{b})}$ \\
\hline & $\begin{array}{l}\text { Corrected maximum specific optical density, } \\
D_{s}(\text { corr) (nonflaming) }\end{array}$ & 0.26 & 0.09 & NA \\
\hline \multirow[t]{6}{*}{ None } & Maximum concentration of $\mathrm{CO}$ (ppm) (flaming) & $1681 \pm 18 ; 762 \pm 55$ & -- & NA \\
\hline & Maximum concentration of $\mathrm{CO}(\mathrm{ppm})$ (nonflaming) & $803 \pm 6 ; 88 \pm 1$ & -- & NA \\
\hline & Maximum concentration of $\mathrm{CO}_{2}$ (ppm) (flaming) & $1628 \pm 63 ; 1057 \pm 43$ & -- & NA \\
\hline & Maximum concentration of $\mathrm{CO}_{2}(\mathrm{ppm})$ (nonflaming) & $834 \pm 41 ; 3421 \pm 123$ & -- & NA \\
\hline & Maximum concentration of $\mathrm{SO}_{2}(\mathrm{ppm})$ (flaming) & $7 \pm 2 ; 7 \pm 3$ & -- & NA \\
\hline & Maximum concentration of $\mathrm{SO}_{2}(\mathrm{ppm})$ (nonflaming) & $3 \pm 1 ; 2.3 \pm 1.5$ & -- & NA \\
\hline
\end{tabular}

(a) With deviations described in Section 3.5.

(b) Calculated by multiplying the average value with the relative repeatability limit given in Table 4.7.

-- Not applicable.

NA Not available. 
It is suggested that the gas analyses be repeated so that the large differences in $\mathrm{CO}$ and $\mathrm{CO}_{2}$ concentrations between duplicate results may be better understood.

From the smoke tests based on the light extinction measurements under dynamic (ASTM E1354-10) and static (ASTM E662-09) conditions, it was shown that the SRF resin had smoke production comparable to or slightly higher than that of negative standard materials that are non-combustible. 


\subsection{References}

ASTM D1929-96. 1996. Standard Test Method for Determining Ignition Temperature of Plastics, ASTM International, West Conshohocken, PA.

ASTM D7309-07A. 2007. Standard Test Method for Determining Flammability Characteristics of Plastics and Other Solid Materials Using Microscale Combustion Calorimetry, ASTM International, West Conshohocken, PA.

ASTM E176-10. 2010. Standard Terminology of Fire Standards, ASTM International, West Conshohocken, PA.

ASTM E177-10. 2010. Standard Practice for Use of the Terms Precision and Bias in ASTM Test Methods, ASTM International, West Conshohocken, PA.

ASTM E662-09. 2009. Standard Test Method for Specific Optical Density of Smoke Generated by Solid Materials, ASTM International, West Conshohocken, PA.

ASTM E800-07. 2007. Standard Guide for Measurement of Gases Present or Generated During Fires, ASTM International, West Conshohocken, PA.

ASTM E1354-10. 2010. Standard Test Method for Heat and Visible Smoke Release Rates for Materials and Products Using an Oxygen Consumption Calorimeter, ASTM International, West Conshohocken, PA.

ISO 5659-1:1996. Plastics - Smoke generation - Part 1: Guidance on Optical Density Testing, International Organization for Standardization, Geneva, Switzerland.

ISO 5659-2:2006. Plastics - Smoke generation - Part 2: Determination of Optical Density by a SingleChamber Test, International Organization for Standardization, Geneva, Switzerland.

Mulholland. G.W. 1995. Smoke Production and Properties, in SFPE Handbook of Fire Protection Engineering, $2^{\text {nd }}$ Edition, Chapter 15, Section 2, 2/217-2/227.

\section{Not Publically Available}

24590-PTF-TSP-RT-09-002, Rev 0. 2009. RF Resin Cesium Removal with Expanded Load and Elution Conditions, River Protection Project Waste Treatment Plant, Richland, WA.

24590-PTF-TEF-RT-11-00003, Rev 0. 2011. Test Exception to 24590-QL-HC9-WA49-00001-02-00014, Rev 00C (TP-WTPSP-002, Rev 2.0), River Protection Project Waste Treatment Plant, Richland, WA.

TP-WTPSP-002, Rev 3.0. 2011. Cesium Ion Exchange Simulant Testing in Support of M-6, Pacific Northwest National Laboratory, Richland, WA. 

Appendix A

SwRI Reports 



\section{S O U T H W E T R E S E A R C H I N S T I T U T E ${ }^{\circledR}$ \\ 6220 CULEBra RD. $78238-5166$ - P.O. DRAWER $28510 \quad 78228-0510$

\author{
san ANTONIO, TEXas, USA • (210) 684-5111 - WWW.SWri.org \\ Chemistry and Chemical Engineering
} \\ Department of Analytical and Environmental Chemistry}

December 16, 2011

Battelle Memorial Institute - PNNL

MSIN K6-24

$7906^{\text {th }}$ Street

Richland, Washington 99354

Attention: Renee Russell

Subject: Purchase Order No.: 167930

SDG Number: $\quad 479235$

SwRI Project No.: 13295.12.00X

SwRI Task Order No.: 111111-12

SwRI Sample Receipt No.: $\quad 46069$

Samples Received: $\quad 11 / 11 / 11$

Required Analysis: $\quad$ Various / See RFP 190709

Dear Ms. Russell,

Please find the enclosed results for the one overall sample received on the above referenced date. Should you have any questions, please feel free to contact me at (210) 522-5428, michael.dammann@swri.org.

Best Regards,

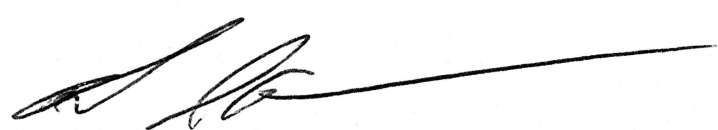

Michael J. Dammann

Director 
SOUTHWEST RESEARCH INSTITUTE CLIENT: Battelle Memorial Ins. PNNL TASK ORDER\#:

SRR\#:

SDG\#:

VTSR:

111111-12

46069

479235

PROJECT \#:

$11 / 11 / 2011$

13295.12.00X

\section{R13295.12.008a (ASTM D 1929 Testing)}




\section{S O U T H W E S T R E S E A R C H I N S T I T U T E}

ASTM D 1929 - 96 (RE-APPROVED 2001), STANDARD

TEST METHOD FOR DETERMINING IGNITION

TEMPERATURE OF PLASTICS

MATERIAL ID: RESORCINOL-FORMALDEHYDE POLYMER

FINAL REPORT

Consisting of 10 Pages

SwRI ${ }^{\circledR}$ Project No. 01.13295.12.008a

Test Dates: November 29, and December 1-3 and 5, 2011

Report Date: December 16, 2011

\section{Prepared for:}

\section{Battelle Memorial Institute}

902 Battelle Blvd, K6-79

P.O. Box 999

Richland, WA 99352

Submitted by:

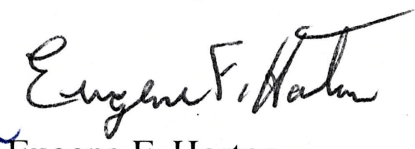

Eugene F. Horton

Senior Engineering Technologist Material Flammability Section
Approved by:

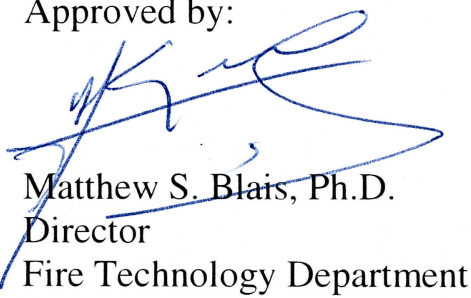

This report is for the information of the client. It may be used in its entirety for the purpose of securing product acceptance from duly constituted approval authorities. This report shall not be reproduced except in full, without the written approval of SwRI. Neither this report nor the name of the Institute shall be used in publicity or advertising. 


\subsection{INTRODUCTION}

ASTM D 1929, Standard Test Method for Determining Ignition Temperature of Plastics, covers a laboratory determination of the spontaneous ignition temperature (SIT) and flash ignition temperature (FIT) of plastics using a hot-air furnace. The hot-air ignition furnace consists primarily of an electrical heating unit and specimen holder. The furnace tube is a vertical tube with an inside diameter of $100 \pm 5 \mathrm{~mm}$ and a length of $230 \pm 20 \mathrm{~mm}$, made of ceramic that will withstand at least $750{ }^{\circ} \mathrm{C}$. The inner ceramic tube, with an inside diameter of $75 \pm 5 \mathrm{~mm}$, a length of $230 \pm 20 \mathrm{~mm}$, and a thickness of approximately $3 \mathrm{~mm}$, is placed inside the furnace tube and positioned $20 \pm 2 \mathrm{~mm}$ above the furnace floor on spacer blocks. The pilot flame is located immediately above the opening. The test apparatus is shown in Figure 1.

Testing was performed on the test samples in accordance with the quality assurance requirements of the DOE/RL-96-68, Hanford Analytical Services Quality Assurance Requirements Documents, Volumes 1 and 4 (HASQARDS), latest revision. In accordance with the HASQARDs, a positive, a negative, and duplicate tests were run, in addition to the one standard test. The positive tests were performed on PMMA (Poly methyl methacrylate). This is a know standard used in testing and it was selected as the positive standard. The negative tests were performed on marinate board, which is a non-combustible material. This material is often used as a substrate or backer board in standard fire testing. It does not react to flame or heat except to lose moisture.

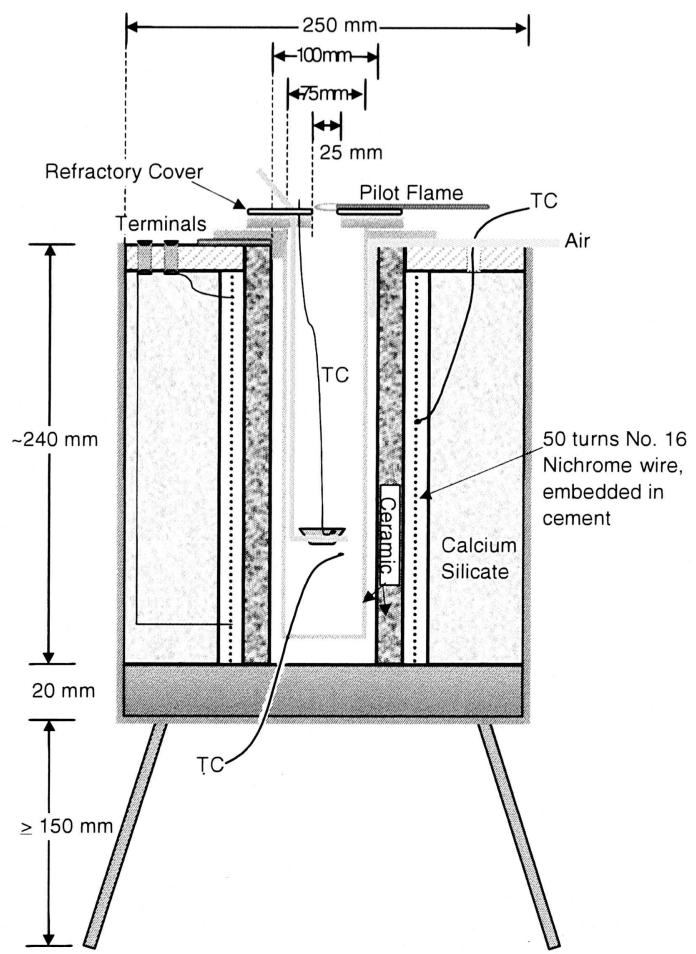

Figure 1. Schematic of Southwest Research Institute (SwRI) Hot-Air Furnace.

SIT is the minimum temperature at which the self-heating properties of the specimen lead to ignition or ignition occurs of itself, under specified test conditions, in the absence of any additional 
flame ignition source. The lowest air temperature at which the specimen ignites during a 10-min period is recorded as the spontaneous ignition temperature.

FIT is the minimum temperature at which, under specified test conditions, sufficient flammable gases are emitted to ignite momentarily upon application of a small external pilot flame. The lowest air temperature at which a flash is observed during a 10-min period is recorded as the flash ignition temperature.

\subsection{SAMPLE IDENTIFICATION AND PREPARATION}

Battelle Memorial Institute, located in Richland, Washington, provided a material identified as Resorcinol-Formaldehyde Polymer for testing in accordance with ASTM D 1929. A description of the material provided by the client can be found in Table 1. On November 11, 2011, SwRI received one 20-L bottle of specimen described in the table below.

Table 1. SAMPle Description Provided by Battelle Memorial InStitute.

\begin{tabular}{|c|c|c|}
\hline Material ID & Description & Color \\
\hline \hline Resorcinol-Formaldehyde Polymer & Micro Bead & Red \\
\hline
\end{tabular}

The samples provided consisted of a micro bead material dispersed in water. The material was tested in worst case scenario, which is with the water removed. This process was achieved by first filtering the material, and then drying it in an oven. The sample was dried for a minimum of $10 \mathrm{~h}$ at $60{ }^{\circ} \mathrm{C} \pm 3{ }^{\circ} \mathrm{C}\left(140{ }^{\circ} \mathrm{F} \pm 5^{\circ} \mathrm{F}\right)$ prior to testing. After drying, the sample consisted of only the micro bead material; the beads became statically charged in the absence of the water medium and; therefore, they were placed in a closed container after drying, in an effort not to lose any beads. Each sample was then conditioned in a controlled environment maintained at $23{ }^{\circ} \mathrm{C} \pm 3{ }^{\circ} \mathrm{C}$ and $50 \% \pm 5 \%$ relative humidity until just prior to testing, but for not less than $40 \mathrm{~h}$ prior to testing.

\subsection{RESULTS}

Testing was conducted November 29, and December 1-3 and 5, 2011. Table 2 contains the results for the material provided by Battelle Memorial Institute. Test results are accurate to $\pm 5{ }^{\circ} \mathrm{C}$, and are presented in detail at the end of this report. These test results relate only to the behavior of test specimens under the particular conditions of the test. They are not intended to be used, and shall not be used, to assess the potential fire hazards of a material in use.

TABLE 2. IgNition TEMPERATURE DATA.

\begin{tabular}{|c|c|c||}
\hline Material ID & SIT & FIT \\
\hline \hline Resorcinol-Formaldehyde Polymer & $615^{\circ} \mathrm{C}$ & $600{ }^{\circ} \mathrm{C}$ \\
\hline Resorcinol-Formaldehyde Polymer (Duplicate Run) & $610^{\circ} \mathrm{C}$ & $590{ }^{\circ} \mathrm{C}$ \\
\hline Marinite, Negative Standard & NA & NA \\
\hline$P M M A$, Positive Standard & $420{ }^{\circ} \mathrm{C}$ & NA \\
\hline
\end{tabular}




\section{APPENDiX A}

\section{ASTM D 1929 TeSt Data Sheets}

\section{(Consisting of 6 Pages)}


S OUTHWES T RESEARCH INS TITUTE

\section{ASTM D 1929 TEST DATA SHEET - SPONTANEOUS IGNITION}

Client:

Operator:

Test Date(s):

Material ID*:

Description *
Battelle Memorial Institute

A. Lowry

December 2, 2011

Marinite, Negative Standard

Solid White Composite
Ignition Type:

Receipt Date:

Date Prepared by SwRI:

Color:

Average Sample Mass: $2.89 \mathrm{~g}$
Spontaneous

November 11, 2011

Cut to size on test date

White

* Information/instructions provided by the Client

SPONTANEOUS IGNITION TEMPERATURE $\left({ }^{\circ} \mathrm{C}\right)$

NA

RESULTS

\begin{tabular}{|c|c|c|c|c|c|c|c|c|c|c|}
\hline \multirow[t]{2}{*}{ Test ID } & \multirow{2}{*}{$\begin{array}{c}\text { Initial } \\
\text { Mass } \\
(\mathrm{g})\end{array}$} & \multirow{2}{*}{$\begin{array}{c}\text { Final } \\
\text { Mass } \\
(\mathrm{g})\end{array}$} & \multirow{2}{*}{$\begin{array}{c}\text { Mass } \\
\text { Loss } \\
(\mathrm{g})\end{array}$} & \multicolumn{3}{|c|}{ Initial Temperature $\left({ }^{\circ} \mathrm{C}\right)$} & \multicolumn{3}{|c|}{ Final Temperature $\left({ }^{\circ} \mathrm{C}\right)$} & \multirow[b]{2}{*}{ Ignition } \\
\hline & & & & Sample & Air & Furnace & Sample & Air & Furnace & \\
\hline \begin{tabular}{|l} 
11-336PNN008E15 \\
\end{tabular} & 2.89 & 2.62 & 0.27 & 750 & 750 & 809 & 751 & 753 & 809 & No \\
\hline
\end{tabular}

SPONTANEOUS IGNITION OBSERVATIONS

\begin{tabular}{|l|cccccccc|}
\hline & $\begin{array}{c}\text { Insertion } \\
\text { Time } \\
\text { (min:s) }\end{array}$ & $\begin{array}{c}\text { Observed } \\
\text { Smoke } \\
\text { (min:s) }\end{array}$ & $\begin{array}{c}\text { Combustion } \\
\text { Time } \\
\text { (min:s) }\end{array}$ & $\begin{array}{c}\text { Observed } \\
\text { Soot }\end{array}$ & $\begin{array}{c}\text { Observed } \\
\text { Charring }\end{array}$ & $\begin{array}{c}\text { Observed } \\
\text { Melt }\end{array}$ & $\begin{array}{c}\text { Observed } \\
\text { Bubbling }\end{array}$ & $\begin{array}{c}\text { Total Test } \\
\text { Time } \\
(m i n: s)\end{array}$ \\
\hline 11-336PNN008E15 & $0: 47$ & NA & NA & None & None & None & None & $10: 48$ \\
\end{tabular}

Negative Standard SIT Test

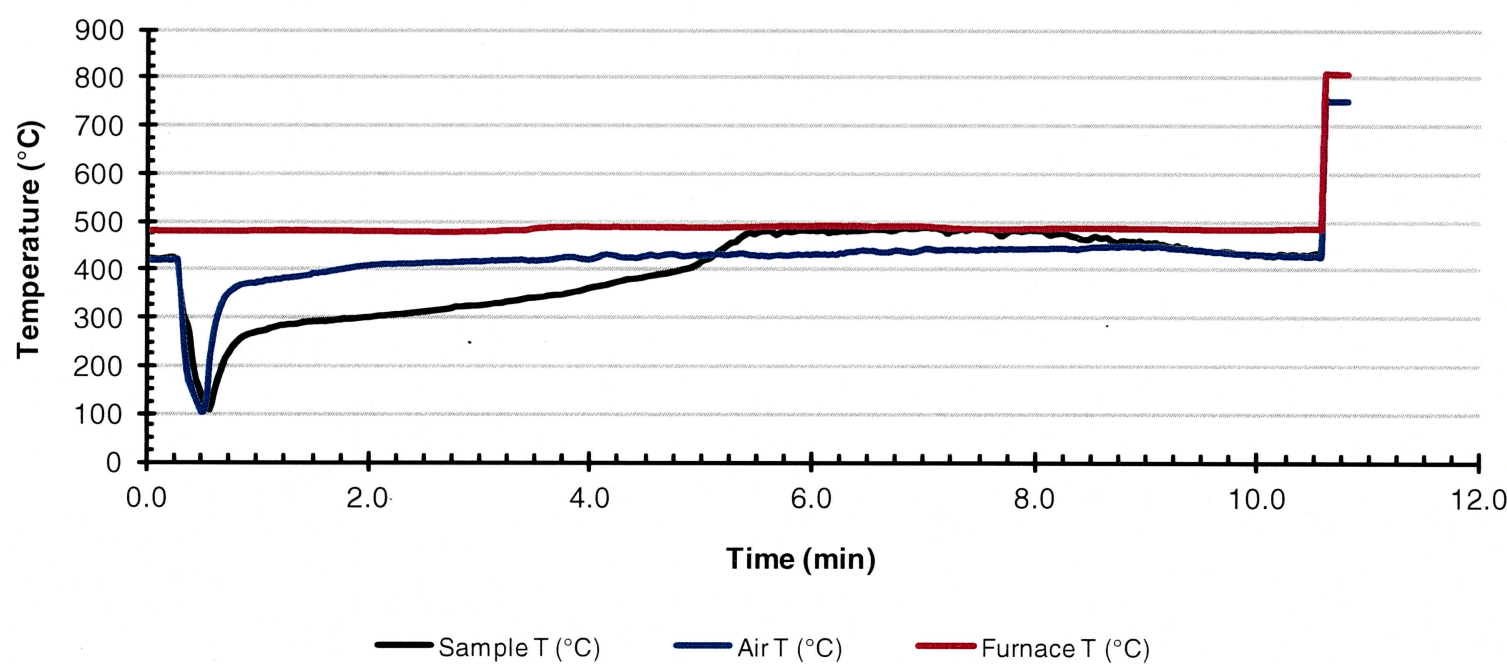


SOUTHWEST RES EARCH INS TITUTE

\section{ASTM D 1929 TEST DATA SHEET - SPONT ANEOUS IGNITION}

\author{
Client: \\ Operator: \\ Test Date(s): \\ Material ID*: \\ Description * \\ Battelle Memorial Institute \\ A. Lowry \\ December 3 and 5, 2011 \\ PMMA, Positive Standard \\ Solid Black Composite
}

Ignition Type:

Receipt Date:

Date Prepared by SwRI:

Color:

Average Sample Mass:
Spontaneous

November 11, 2011

Cut to size on test date

Black

$3.01 \mathrm{~g}$

SPONTANEOUS IGNITION TEMPERATURE $\left({ }^{\circ} \mathrm{C}\right)$ :

420

* Information/instructions provided by the Client

\section{RESULTS}

\begin{tabular}{|c|c|c|c|c|c|c|c|c|c|c|}
\hline \multirow[t]{2}{*}{ Test ID } & \multirow{2}{*}{$\begin{array}{c}\text { Initial } \\
\text { Mass } \\
\text { (g) }\end{array}$} & \multirow{2}{*}{$\begin{array}{c}\text { Final } \\
\text { Mass } \\
\text { (g) }\end{array}$} & \multirow{2}{*}{$\begin{array}{l}\text { Mass } \\
\text { Loss } \\
\text { (g) }\end{array}$} & \multicolumn{3}{|c|}{ Initial Temperature $\left({ }^{\circ} \mathrm{C}\right)$} & \multicolumn{3}{|c|}{ Final Temperature $\left({ }^{\circ} \mathrm{C}\right)$} & \multirow[b]{2}{*}{ Ignition } \\
\hline & & & & Sample & Air & Furnace & Sample & Air & Furnace & \\
\hline 11-337PNN008F65 & 3.15 & 0.75 & 2.40 & 417 & 410 & 467 & 422 & 407 & 474 & No \\
\hline 11-337PNN008F45 & 2.87 & 0.00 & 2.87 & 423 & 420 & 479 & 434 & 429 & 484 & Yes \\
\hline
\end{tabular}

\section{SPONTANEOUS IGNITION OBSERVATIONS}

\begin{tabular}{|l|cccccccc|}
\hline & $\begin{array}{c}\text { Insertion } \\
\text { Time } \\
\text { (min:s) }\end{array}$ & $\begin{array}{c}\text { Observed } \\
\text { Smoke } \\
\text { (min:s) }\end{array}$ & $\begin{array}{c}\text { Combustion } \\
\text { Time } \\
\text { (min:s) }\end{array}$ & $\begin{array}{c}\text { Observed } \\
\text { Soot }\end{array}$ & $\begin{array}{c}\text { Observed } \\
\text { Charring }\end{array}$ & $\begin{array}{c}\text { Observed } \\
\text { Melt }\end{array}$ & $\begin{array}{c}\text { Observed } \\
\text { Bubbling }\end{array}$ & $\begin{array}{c}\text { Total Test } \\
\text { Time } \\
\text { (min:s) }\end{array}$ \\
\hline 11-337PNN008F65 & $0: 36$ & NA & NA & None & Yes & None & Yes & $10: 36$ \\
11-337PNN008F45 & $0: 34$ & NA & $5: 15$ & None & Yes & None & None & $10: 34$ \\
\hline
\end{tabular}

Positive Standard SIT Test

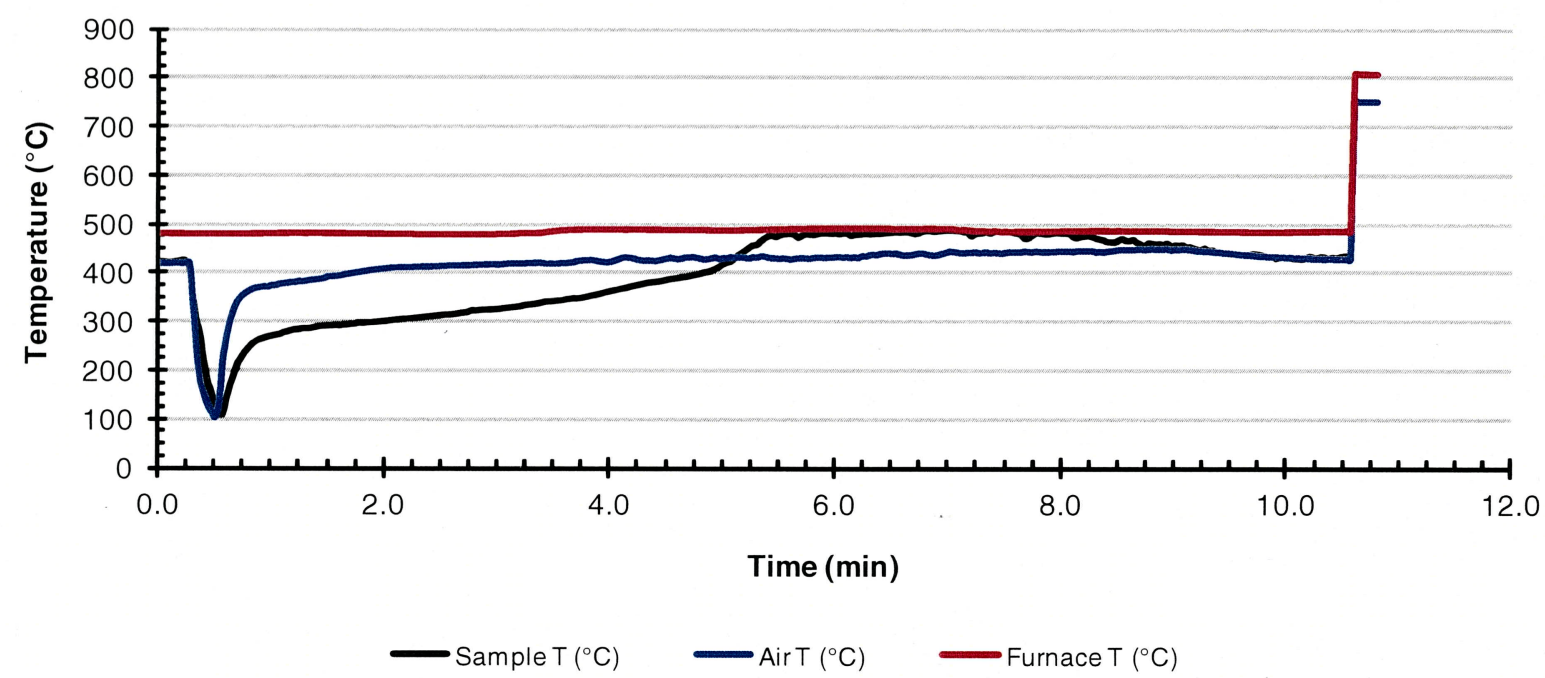


S OUTHW ES T RES EAR CH INS TITUTE

ASTM D 1929 TEST DATA SHEET - SPONTANEOUS IGNITION

\author{
Client: \\ Operator: \\ Test Date(s): \\ Material ID*: \\ Description*: \\ Battelle Memorial Institute \\ Nathaniel Ramos \\ November 29, 2011 \\ Resorcinol-Formaldehyde Polymer \\ Small Beads
}

Ignition Type:

Receipt Date:

Date Prepared by SwRI:

Color:

Average Sample Mass:
Spontaneous

November 11, 2011

Cut to size on test date

Red

$3.00 \mathrm{~g}$

SPONTANEOUS IGNITION TEMPERATURE $\left({ }^{\circ} \mathrm{C}\right)$ :

615

*Information/instructions provided by the Client

RESULTS

\begin{tabular}{|c|c|c|c|c|c|c|c|c|c|c|}
\hline \multirow[t]{2}{*}{ Test ID } & \multirow{2}{*}{$\begin{array}{c}\text { Initial } \\
\text { Mass } \\
\text { (g) }\end{array}$} & \multirow{2}{*}{$\begin{array}{c}\text { Final } \\
\text { Mass } \\
(\mathrm{g})\end{array}$} & \multirow{2}{*}{$\begin{array}{c}\text { Mass } \\
\text { Loss } \\
(\mathrm{g})\end{array}$} & \multicolumn{3}{|c|}{ Initial Temperature $\left({ }^{\circ} \mathrm{C}\right)$} & \multicolumn{3}{|c|}{ Final Temperature $\left({ }^{\circ} \mathrm{C}\right)$} & \multirow[b]{2}{*}{ Ignition } \\
\hline & & & & Sample & Air & Furnace & Sample & Air & Furnace & \\
\hline 11-333PNN00A75 & 3.00 & 1.31 & 1.69 & 609 & 605 & 603 & 633 & 614 & 662 & No \\
\hline 11-333PNN00A65 & 3.00 & 1.24 & 1.76 & 615 & 615 & 675 & 670 & 626 & 678 & Yes \\
\hline 11-333PNN00A55 & 3.00 & 1.25 & 1.75 & 630 & 625 & 684 & 676 & 635 & 687 & Yes \\
\hline
\end{tabular}

\section{SPONTANEOUS IGNITION OBSERVATIONS}

\begin{tabular}{|c|c|c|c|c|c|c|c|c|}
\hline & $\begin{array}{l}\text { Insertion } \\
\text { Time } \\
\text { (min:s) }\end{array}$ & $\begin{array}{c}\text { Observed } \\
\text { Smoke } \\
\text { (min:s) }\end{array}$ & $\begin{array}{c}\text { Combustion } \\
\text { Time } \\
\text { (min:s) }\end{array}$ & $\begin{array}{c}\text { Observed } \\
\text { Soot }\end{array}$ & $\begin{array}{c}\text { Observed } \\
\text { Charring }\end{array}$ & $\begin{array}{c}\text { Observed } \\
\text { Melt }\end{array}$ & $\begin{array}{l}\text { Observed } \\
\text { Bubbling }\end{array}$ & $\begin{array}{c}\text { Total Test } \\
\text { Time } \\
\text { (min:s) }\end{array}$ \\
\hline 11-333PNN00A75 & $1: 56$ & NA & $0: 00$ & None & Yes & None & None & $10: 00$ \\
\hline 11-333PNN00A65 & $1: 23$ & NA & $2: 21$ & None & Yes & None & None & $10: 00$ \\
\hline 11-333PNN00A55 & $1: 42$ & NA & $2: 35$ & None & Yes & None & None & $10: 00$ \\
\hline
\end{tabular}

Fermaldehyde SIT Test 1

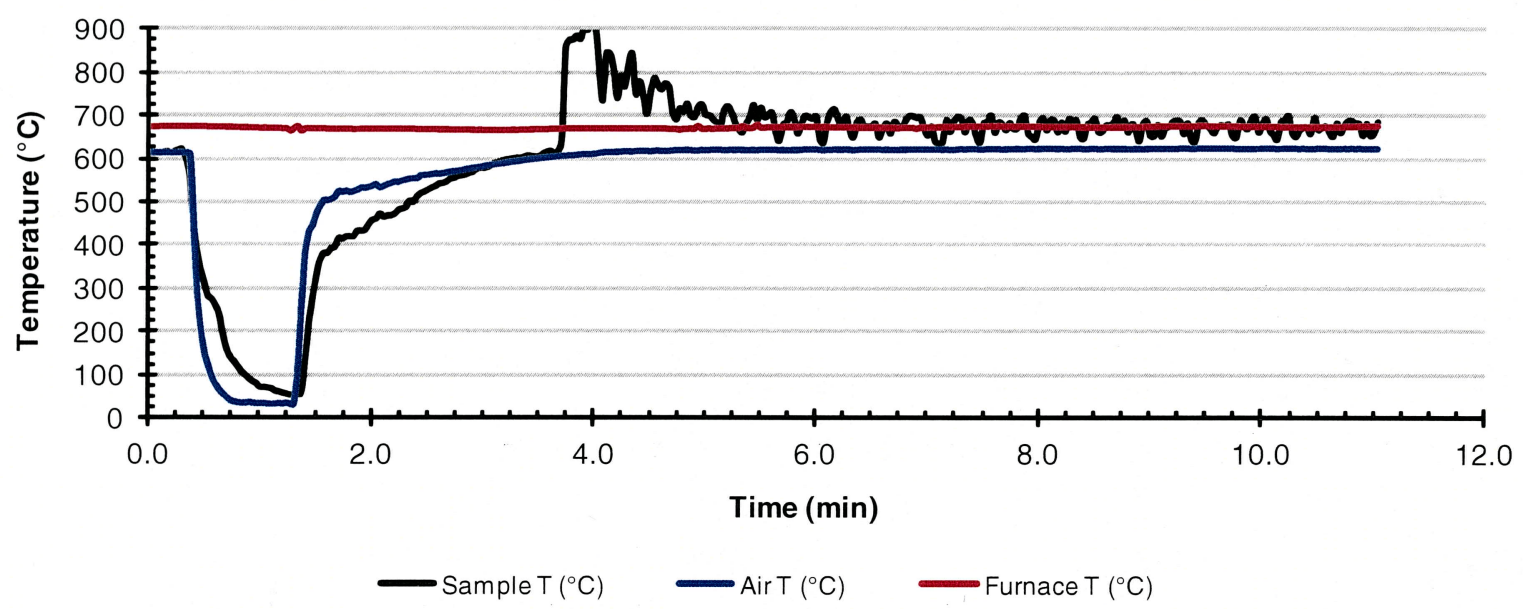


S OUTHWEST RES EARCH INS TITUTE

\section{ASTM D 1929 TEST DATA SHEET - FLASH IGNITION}

\author{
Client: \\ Operator: \\ Test Date(s): \\ Material ID*: \\ Description*: \\ Battelle Memorial Institute \\ Nathaniel Ramos \\ December 1, 2011 \\ Resorcinol-Formaldehyde Polymer \\ Small Beads
}

Ignition Type:

Receipt Date:

Date Prepared by SwRI:

Color:

Average Sample Mass: $3.14 \mathrm{~g}$
Flash

November 11, 2011

Tested as received

Red

* Information/instructions provided by the Client

FLASH IGNITION TEMPERATURE $\left({ }^{\circ} \mathrm{C}\right)$ :

420

RESULTS

\begin{tabular}{|c|c|c|c|c|c|c|c|c|c|c|}
\hline \multirow[t]{2}{*}{ Test ID } & \multirow{2}{*}{$\begin{array}{c}\text { Initial } \\
\text { Mass } \\
\text { (g) }\end{array}$} & \multirow{2}{*}{$\begin{array}{c}\text { Final } \\
\text { Mass } \\
(\mathrm{g})\end{array}$} & \multirow{2}{*}{$\begin{array}{c}\text { Mass } \\
\text { Loss } \\
\text { (g) }\end{array}$} & \multicolumn{3}{|c|}{ Initial Temperature $\left({ }^{\circ} \mathrm{C}\right)$} & \multicolumn{3}{|c|}{ Final Temperature $\left({ }^{\circ} \mathrm{C}\right)$} & \multirow[b]{2}{*}{ Ignition } \\
\hline & & & & Sample & Air & Furnace & Sample & Air & Furnace & \\
\hline 11-336PNN00B4F & 3.00 & 1.53 & 1.47 & 591 & 590 & 649 & 628 & 598 & 648 & No \\
\hline 11-335PNN00B1F & 3.14 & 0.75 & 2.39 & 425 & 420 & 436 & 448 & 408 & 435 & Yes \\
\hline
\end{tabular}

FLASH IGNITION OBSERVATIONS

\begin{tabular}{|c|c|c|c|c|c|c|c|c|}
\hline & $\begin{array}{l}\text { Insertion } \\
\text { Time } \\
\text { (min:s) }\end{array}$ & $\begin{array}{l}\text { Observed } \\
\text { Smoke } \\
(\min : s)\end{array}$ & $\begin{array}{c}\text { Combustion } \\
\text { Type } \\
\text { (min:s) }\end{array}$ & $\begin{array}{l}\text { Observed } \\
\text { Soot } \\
\text { (min:s) }\end{array}$ & $\begin{array}{l}\text { Observed } \\
\text { Charring }\end{array}$ & $\begin{array}{c}\text { Observed } \\
\text { Melt }\end{array}$ & $\begin{array}{l}\text { Observed } \\
\text { Bubbling }\end{array}$ & $\begin{array}{c}\text { Total Test } \\
\text { Time } \\
\text { (min:s) }\end{array}$ \\
\hline 11-336PNN00B4F & $0: 40$ & NA & NA & None & Yes & None & None & $10: 40$ \\
\hline 11-335PNN00B1F & $0: 59$ & NA & Flaming at 5:15 & None & Yes & None & None & $8: 26$ \\
\hline
\end{tabular}

Fermaldehyde FIT Test 1

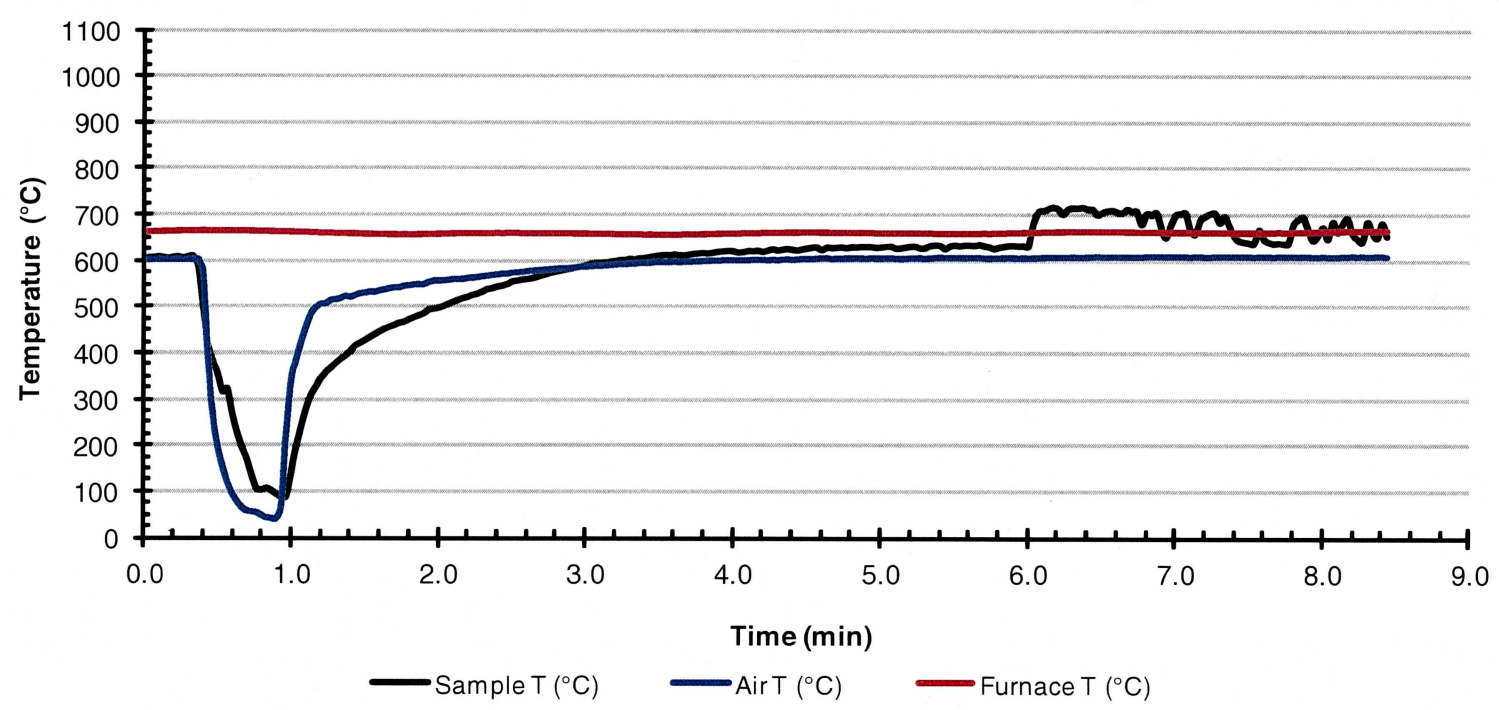




\section{S OUTHWES T RESEARCH INS TITUTE}

\section{ASTM D 1929 TEST DATA SHEET - SPONT ANEOUS IGNITION}

Client:

Operator:

Test Date(s):

Material ID*:

Description*:
Battelle Memorial Institute

A. Lowry

December 2, 2011

Resorcinol-Formaldehyde Polymer

Small Beads
Ignition Type:

Receipt Date:

Date Prepared by SwRI:

Color:

Average Sample Mass:
Spontaneous

November 11, 2011

Cut to size on test date

Red

$3.00 \mathrm{~g}$

SPONTANEOUS IGNITION TEMPERATURE $\left({ }^{\circ} \mathrm{C}\right)$ :

610

* Information/instructions provided by the Client

\section{RESULTS}

\begin{tabular}{|c|c|c|c|c|c|c|c|c|c|c|}
\hline \multirow[t]{2}{*}{ Test ID } & Initial & Final & Mass & \multicolumn{3}{|c|}{ Initial Temperature $\left({ }^{\circ} \mathrm{C}\right)$} & \multicolumn{3}{|c|}{ Final Temperature $\left({ }^{\circ} \mathrm{C}\right)$} & \multirow[b]{2}{*}{ Ignition } \\
\hline & $\begin{array}{c}\text { Mass } \\
(\mathrm{g})\end{array}$ & $\begin{array}{c}\text { Mass } \\
\text { (g) }\end{array}$ & $\begin{array}{c}\text { Loss } \\
\text { (g) }\end{array}$ & Sample & Air & Furnace & Sample & Air & Furnace & \\
\hline 11-336PNN00D15 & 3.00 & 1.54 & 1.46 & 603 & 600 & 658 & 640 & 609 & 658 & No \\
\hline 11-336PNN00D25 & 3.00 & 1.76 & 1.24 & 611 & 610 & 669 & 659 & 619 & 670 & Yes \\
\hline
\end{tabular}

\section{SPONTANEOUS IGNITION OBSERVATIONS}

\begin{tabular}{|l|cccccccc|}
\hline & $\begin{array}{c}\text { Insertion } \\
\text { Time } \\
\text { (min:s) }\end{array}$ & $\begin{array}{c}\text { Observed } \\
\text { Smoke } \\
\text { (min:s) }\end{array}$ & $\begin{array}{c}\text { Combustion } \\
\text { Time } \\
\text { (min:s) }\end{array}$ & $\begin{array}{c}\text { Observed } \\
\text { Soot }\end{array}$ & $\begin{array}{c}\text { Observed } \\
\text { Charring }\end{array}$ & $\begin{array}{c}\text { Observed } \\
\text { Melt }\end{array}$ & $\begin{array}{c}\text { Observed } \\
\text { Bubbling }\end{array}$ & $\begin{array}{c}\text { Total Test } \\
\text { Time } \\
\text { (min:s) }\end{array}$ \\
\hline 11-336PNN00D15 & $0: 34$ & NA & NA & None & Yes & None & None & $10: 34$ \\
11-336PNN00D25 & $0: 31$ & NA & $2: 34$ & None & Yes & None & None & $6: 00$ \\
\hline
\end{tabular}

Fermaldehyde SIT Test 2 (Duplicate)

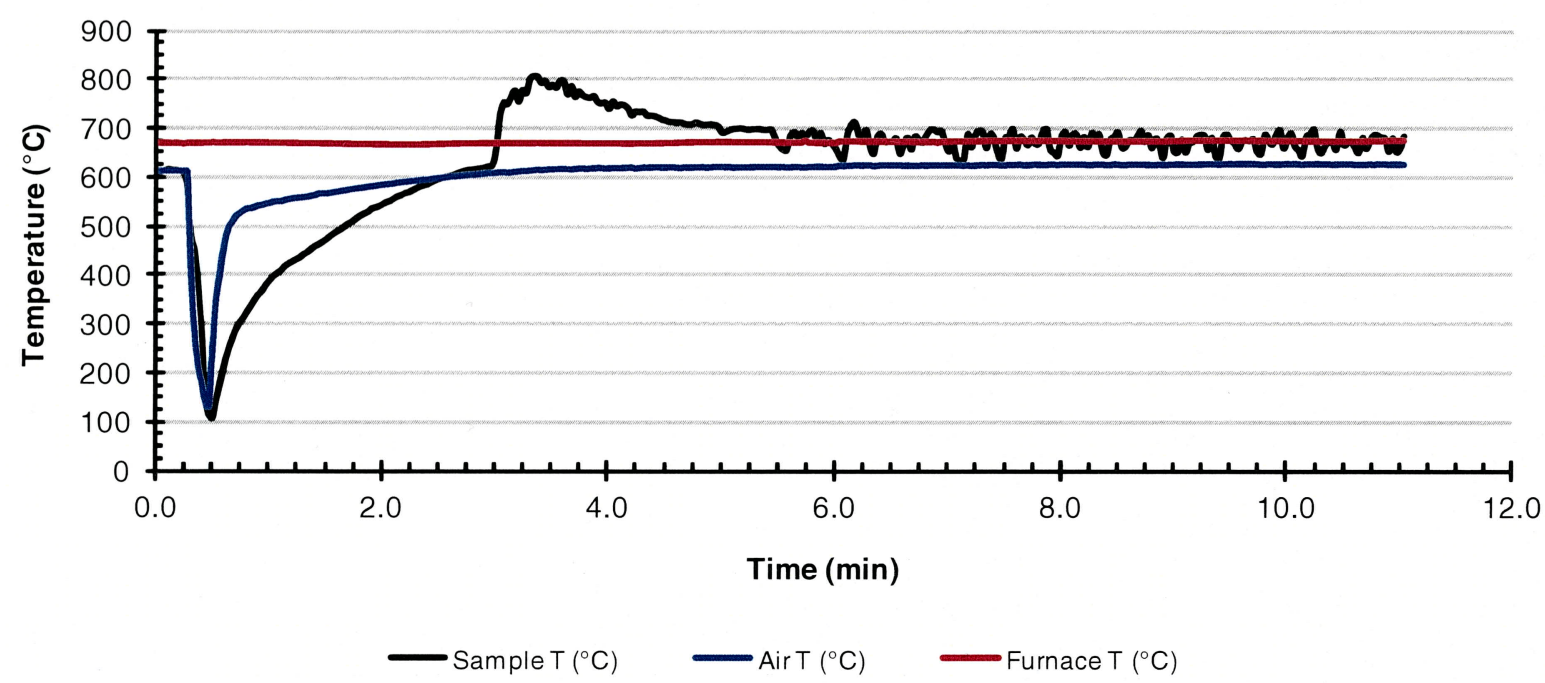


S OUTHW ES T RES EARCH INS TITUTE

\section{ASTM D 1929 TEST DATA SHEET - FLASH IGNITION}

\author{
Client: \\ Operator: \\ Test Date(s): \\ Material ID*: \\ Description*: \\ Battelle Memorial Institute \\ A. Lowry \\ December 2, 2011 \\ Resorcinol-Formaldehyde Polymer \\ Small Beads
}

\author{
Ignition Type: $\quad$ Flash \\ Receipt Date: $\quad$ November 11, 2011 \\ Date Prepared by SwRI: Tested as received \\ Color: Red \\ Average Sample Mass: $3.00 \mathrm{~g}$
}

\section{RESULTS}

\begin{tabular}{|c|c|c|c|c|c|c|c|c|c|c|}
\hline \multirow[t]{2}{*}{ Test ID } & \multirow{2}{*}{$\begin{array}{c}\text { Initial } \\
\text { Mass } \\
\text { (g) }\end{array}$} & \multirow{2}{*}{$\begin{array}{c}\text { Final } \\
\text { Mass } \\
\text { (g) }\end{array}$} & \multirow{2}{*}{$\begin{array}{c}\text { Mass } \\
\text { Loss } \\
(\mathrm{g})\end{array}$} & \multicolumn{3}{|c|}{ Initial Temperature $\left({ }^{\circ} \mathrm{C}\right)$} & \multicolumn{3}{|c|}{ Final Temperature $\left({ }^{\circ} \mathrm{C}\right)$} & \multirow[b]{2}{*}{ Ignition } \\
\hline & & & & Sample & Air & Furnace & Sample & Air & Furnace & \\
\hline 11-336PNN00C3F & 3.00 & 1.57 & 1.43 & 599 & 580 & 639 & 622 & 590 & 641 & Yes \\
\hline 11-335PNN00C2F & 3.00 & 1.45 & 1.55 & 589 & 590 & 649 & 633 & 600 & 649 & Yes \\
\hline 11-335PNN00C1F & 3.00 & 1.40 & 1.60 & 576 & 600 & 659 & 639 & 611 & 660 & No \\
\hline
\end{tabular}

\section{FLASH IGNITION OBSERVATIONS}

\begin{tabular}{|c|c|c|c|c|c|c|c|c|}
\hline & $\begin{array}{l}\text { Insertion } \\
\text { Time } \\
\text { (min:s) }\end{array}$ & $\begin{array}{l}\text { Observed } \\
\text { Smoke } \\
\text { (min:s) }\end{array}$ & $\begin{array}{c}\text { Combustion } \\
\text { Type } \\
\text { (min:s) }\end{array}$ & $\begin{array}{l}\text { Observed } \\
\text { Soot } \\
\text { (min:s) }\end{array}$ & $\begin{array}{c}\text { Observed } \\
\text { Charring }\end{array}$ & $\begin{array}{c}\text { Observed } \\
\text { Melt }\end{array}$ & $\begin{array}{l}\text { Observed } \\
\text { Bubbling }\end{array}$ & $\begin{array}{c}\text { Total Test } \\
\text { Time } \\
\text { (min:s) }\end{array}$ \\
\hline 11-336PNN00C3F & $0: 40$ & NA & NA & None & Yes & None & None & $10: 40$ \\
\hline 11-335PNN00C2F & $0: 41$ & NA & Flaming at 5:39 & None & Yes & None & None & $10: 42$ \\
\hline 11-335PNN00C1F & $0: 41$ & NA & Flaming at $5: 15$ & None & Yes & None & None & $10: 42$ \\
\hline
\end{tabular}

Fermaldehyde FIT Test 2 (Duplicate)

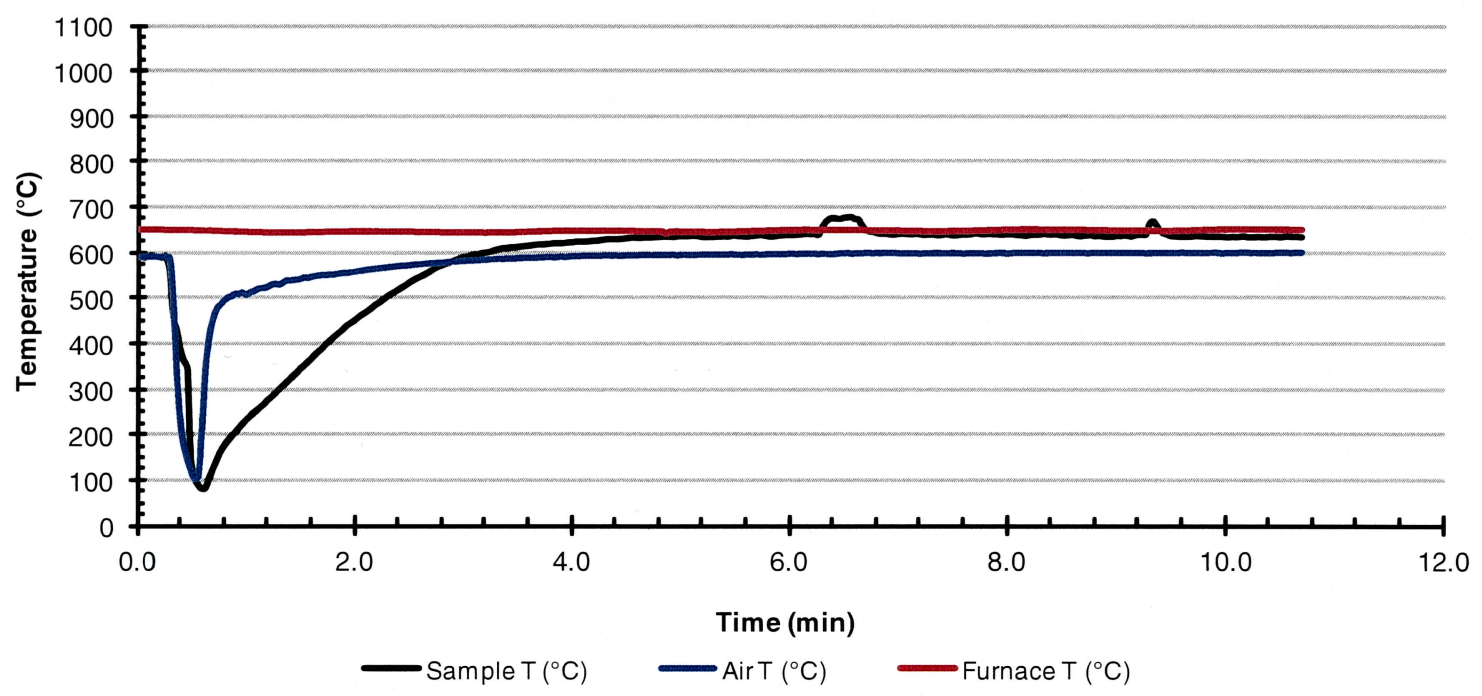


SOUTHWEST RESEARCH INSTITUTE CLIENT: Battelle Memorial Ins. PNNL TASK ORDER\#:

SRR\#:

111111-12

SDG\#:

46069

VTSR:

479235

PROJECT \#:

$11 / 11 / 2011$

13295.12.00X

\section{R13295.12.008c (ASTM E 1354 Testing)}




\section{S O U T H W E S T R E S E A R C H I N S T I T U T E ${ }^{\circledR}$}

CRITICAL HEAT FLUX DETERMINATION USING ASTM E 1354-10, STANDARD TEST METHOD FOR HEAT AND VISIBLE SMOKE RELEASE RATES FOR MATERIALS AND PRODUCTS USING AN OXYGEN CONSUMPTION CALORIMETER

MATERIAL ID: RESORCINOL-FORMALDEHYDE POLYMER

FINAL REPORT

Consisting of 22 Pages

SwRI ${ }^{\circledR}$ Project No. 01.13295.12.008c

Test Dates: November 12, 2011 and December 1 and 3, 2011

Report Date: December 16, 2011

Prepared for:

Battelle Memorial Institute

902 Battelle Blvd, K6-79

P.O. Box 999

Richland, WA 99352

Submitted by:

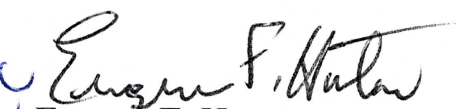

Eugene F. Horton

Senior Engineering Technologist Material Flammability Section

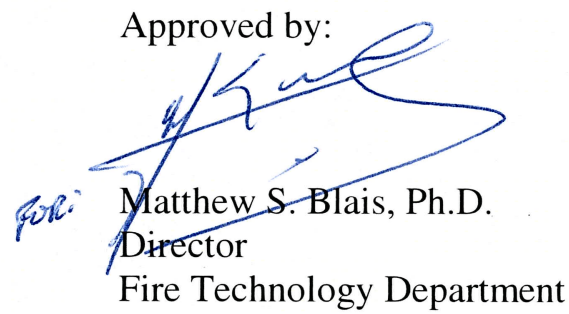

This report is for the information of the Client. It may be used in its entirety for the purpose of securing product acceptance from duly constituted approval authorities. This report shall not be reproduced except in full, without the written approval of SwRI. Neither this report nor the name of the Institute shall be used in publicity or advertising.

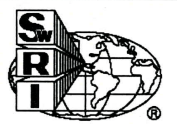




\subsection{INTRODUCTION}

The objective of this test program was to conduct a fire performance evaluation on a material identified as Resorcinol-Formaldehyde Polymer, for Battelle Memorial Institute, located in Richland, Washington. The material was tested in general accordance with ASTM E 1354-10, Standard Test Method for Heat and Visible Smoke Release Rates for Materials and Products Using an Oxygen Consumption Calorimeter. Testing was performed on the test samples in accordance with the quality assurance requirements of the DOE/RL-96-68, Hanford Analytical Services Quality Assurance Requirements Documents, Volumes 1 and 4 (HASQARDS), latest revision. In accordance with the HASQARDs, a positive, a negative and duplicate tests were run, in addition to the one standard test. The test apparatus described in ASTM E 1354 was used to determine the critical heat flux of the material. Testing was conducted at a heat flux of $20,40,50,60,80,100 \mathrm{~kW} / \mathrm{m}^{2}$. Testing was conducted on November 12, 2011, and December 1 and 3, 2011, at Southwest Research Institute's (SwRI) Fire Technology Department, in San Antonio, Texas.

The negative tests were performed on marinate board, which is a non-combustible material. This material is often used as a substrate or backer board in standard fire testing. It does not react to flame or heat except to lose moisture. The positive tests were performed on PMMA (Poly methyl methacrylate). This is a know standard used in testing and it was selected as the positive standard.

This test method is intended to measure and describe the properties of materials or products in response to heat and flame under controlled laboratory conditions. This method is not applicable to end-use products that do not have planar, or nearly planar, external surfaces. The results should not be used alone to describe or appraise the fire hazard or the fire risk of materials, products, or assemblies under actual fire conditions. However, results of this test may be used as elements of a complete fire hazard assessment or a fire risk assessment, which takes into account all the factors that are pertinent to an assessment of the fire hazard or fire risk of a particular end use. The results apply specifically to the specimens tested, in the manner tested, and not to similar materials, nor to the performance when used in combination with other materials.

\subsection{Cone Calorimeter Testing}

The cone calorimeter tests were performed on November 12, 2011, December 1 and 3, 2011. Detailed data summaries and plots can be referenced in Appendix A. Table 1 provides a summary of some of the HRR data. Tables 2 and 3 provide a summary of the ignition data and several selected fire performance indices, based on the heat release and ignition tests. Figure 1 shows a plot developed in order to determine the thermal response parameter from the ignition data. 
Table 1. Cone Calorimeter Summary HRR and Smoke Data*.

\begin{tabular}{|c|c|c|c|c||}
\hline Material ID & $\begin{array}{c}\text { Peak HRR } \\
\left(\mathbf{k W} / \mathbf{m}^{2}\right)\end{array}$ & $\begin{array}{c}\text { THR } \\
\left(\mathbf{M J} / \mathbf{m}^{2}\right)\end{array}$ & $\begin{array}{c}\mathbf{E H C} \\
\mathbf{( M J} / \mathbf{k g})\end{array}$ & $\begin{array}{c}\text { SEA } \\
\left(\mathbf{m}^{2} / \mathbf{k g}\right)\end{array}$ \\
\hline \hline$R C P @ 50 \mathrm{kW/m^{2 }}$ & 44 & 116 & $13.7^{* *}$ & $8^{* * *}$ \\
\hline$R C P @ 100 \mathrm{~kW} / \mathrm{m}^{2}$ & 51 & 123 & 13.3 & $12.5^{* * * *}$ \\
\hline
\end{tabular}

* Data presented in table for testing at $50 \mathrm{~kW} / \mathrm{m}^{2}$ and $100 \mathrm{~kW} / \mathrm{m}^{2}$, are averages of three and six replicate tests, respectively.

** Average EHC for 2 of 3 runs was $12.2 \mathrm{MJ} / \mathrm{kg}$ (one run was $16.7 \mathrm{MJ} / \mathrm{kg}$, which skews the average slightly)

*** Average SEA for 2 of 3 runs was $1.5 \mathrm{~m}^{2} / \mathrm{kg}$ (one run was $22 \mathrm{~m}^{2} / \mathrm{kg}$, which skews the average slightly)

$* * * *$ There is a fair amount of scatter in this measured parameter, likely due to exactly how a given batch of samples was dried prior to testing.

The peak HRR is the maximum single point HRR, as measured by oxygen consumption calorimetry. The total heat released (THR) is the integration of the HRR over the test duration. The effective heat of combustion (EHC) is calculated by dividing the THR by the total mass loss. The specific extinction area (SEA) is a measure of material smoke production. It is calculated as the total smoke produced divided by the total mass loss.

Table 2. Cone Calorimeter Summary of Ignition Fire Indices.

\begin{tabular}{|c|c|c|c|c|}
\hline Material ID & $\begin{array}{c}\text { Surface } \\
\text { Temperature at } \\
\text { Ignition } \\
(\mathbf{K}) \\
\end{array}$ & $\begin{array}{c}\text { CHF for } \\
\text { Ignition - } \\
\text { Extrapolated } \\
\left(\mathbf{k W} / \mathbf{m}^{2}\right) \\
\end{array}$ & $\begin{array}{c}\text { CHF for } \\
\text { Ignition - } \\
\text { Bracketed } \\
\left(\mathrm{kW} / \mathrm{m}^{2}\right) \\
\end{array}$ & $\begin{array}{c}\text { TRP } \\
\left(k W-s^{1 / 2} / m^{2}\right)\end{array}$ \\
\hline$R C P$ & 873 & 40.3 & 42 & 465 \\
\hline
\end{tabular}

Table 3. Cone Calorimeter Summary of Fire Indices.

\begin{tabular}{|c|c|c|c|c|}
\hline Material ID & $\begin{array}{c}\text { Peak HRR at } \\
50 \mathrm{~kW} / \mathrm{m}^{2} \\
(\mathrm{~kW}) \\
\end{array}$ & $\begin{array}{c}\text { FPI at } \\
50 \mathrm{~kW} / \mathrm{m}^{2} \\
\left(\mathrm{~m}^{5 / 3} / \mathrm{kW}^{2 / 3}-\mathrm{s}^{1 / 2}\right) \\
\end{array}$ & $\begin{array}{c}\text { Peak HRR at } \\
100 \mathrm{~kW} / \mathrm{m}^{2} \\
(\mathrm{~kW})\end{array}$ & $\begin{array}{c}\text { FPI at } \\
100 \mathrm{~kW} / \mathrm{m}^{2} \\
\left(\mathrm{~m}^{5 / 3} / \mathrm{kW}^{2 / 3}-\mathrm{s}^{1 / 2}\right) \\
\end{array}$ \\
\hline$R C P$ & 44 & 2.64 & 51 & 2.77 \\
\hline
\end{tabular}

The surface temperature at ignition is the directly measured surface temperature at ignition during the selected ignition tests in the cone calorimeter. The CHF for ignition is calculated from the surface temperature at ignition based on the following equation:

$$
\begin{aligned}
& C H F=\frac{h_{c}}{\varepsilon}\left(T_{i g}-T_{\infty}\right)+\sigma\left(T_{i g}^{4}-T_{\infty}^{4}\right), \text { where } \\
& \mathrm{h}_{\mathrm{c}}=\text { convection coefficient }\left(0.012 \mathrm{~kW} / \mathrm{m}^{2} \mathrm{~K}\right) ; \\
& \varepsilon=\text { surface emissivity (estimated at } 0.9) ; \\
& \mathrm{T}_{\mathrm{ig}}=\text { surface temperature at ignition }(\mathrm{K}) ; \\
& \mathrm{T}_{\infty}=\text { ambient temperature }(293 \mathrm{~K}) ; \text { and } \\
& \sigma=\text { Boltzmann constant }\left(5.67 \times 10^{-11} \mathrm{~kW} / \mathrm{m}^{2} \mathrm{~K}^{4}\right)
\end{aligned}
$$


It is important to note that since the surface temperature at ignition is used for the CHF calculation, the reported value above assumes that this is the absolute minimum heat flux required over an infinitely long heating period to ignite the material. In practice, the ignition tests are conducted for $20 \mathrm{~min}$ and if there is no ignition, the test is concluded and another test is performed at the next heat flux. There is some difference between these calculated critical heat fluxes and the ignition observations both in small-scale and in the standoff distance tests for much shorter heating periods. This explains the difference between the extrapolated and bracketed critical heat fluxes provided in Table 3.

The TRP is a measure of the thermal inertia of a material (product of thermal conductivity, density, and specific heat). It is calculated by plotting the inverse square root of the ignition time versus the external heat flux and fitting a line through the data points. The inverse of the slope of this line is defined as the TRP.

The fire propagation index (FPI) is a measure of full-scale flame spread propensity and is calculated based on ignition data (TRP) and HRR data (peak HRR). Typically, this index is computed with the peak HRR measured at $50 \mathrm{~kW} / \mathrm{m}^{2}$ exposure irradiance to the test specimen. However, since the Client was interested in HRR data at a heat flux of $100 \mathrm{~kW} / \mathrm{m}^{2}$, values of FPI were calculated for both heat fluxes and are provided in Table 4. The FPI is calculated based on the following equation:

$$
\begin{aligned}
F P I & =\frac{1000\left(0.042 \cdot Q_{\text {peak }}\right)^{1 / 3}}{T R P}, \text { where } \\
\mathrm{Q}_{\text {peak }} & =\text { peak heat release rate in cone at } 50 \text { and } 100 \mathrm{~kW} / \mathrm{m}^{2}\left(\mathrm{~kW} / \mathrm{m}^{2}\right) ; \\
\mathrm{TRP} & =\text { thermal response parameter }\left(\mathrm{kW}-\mathrm{s}^{1 / 2} / \mathrm{m}^{2}\right) ;
\end{aligned}
$$




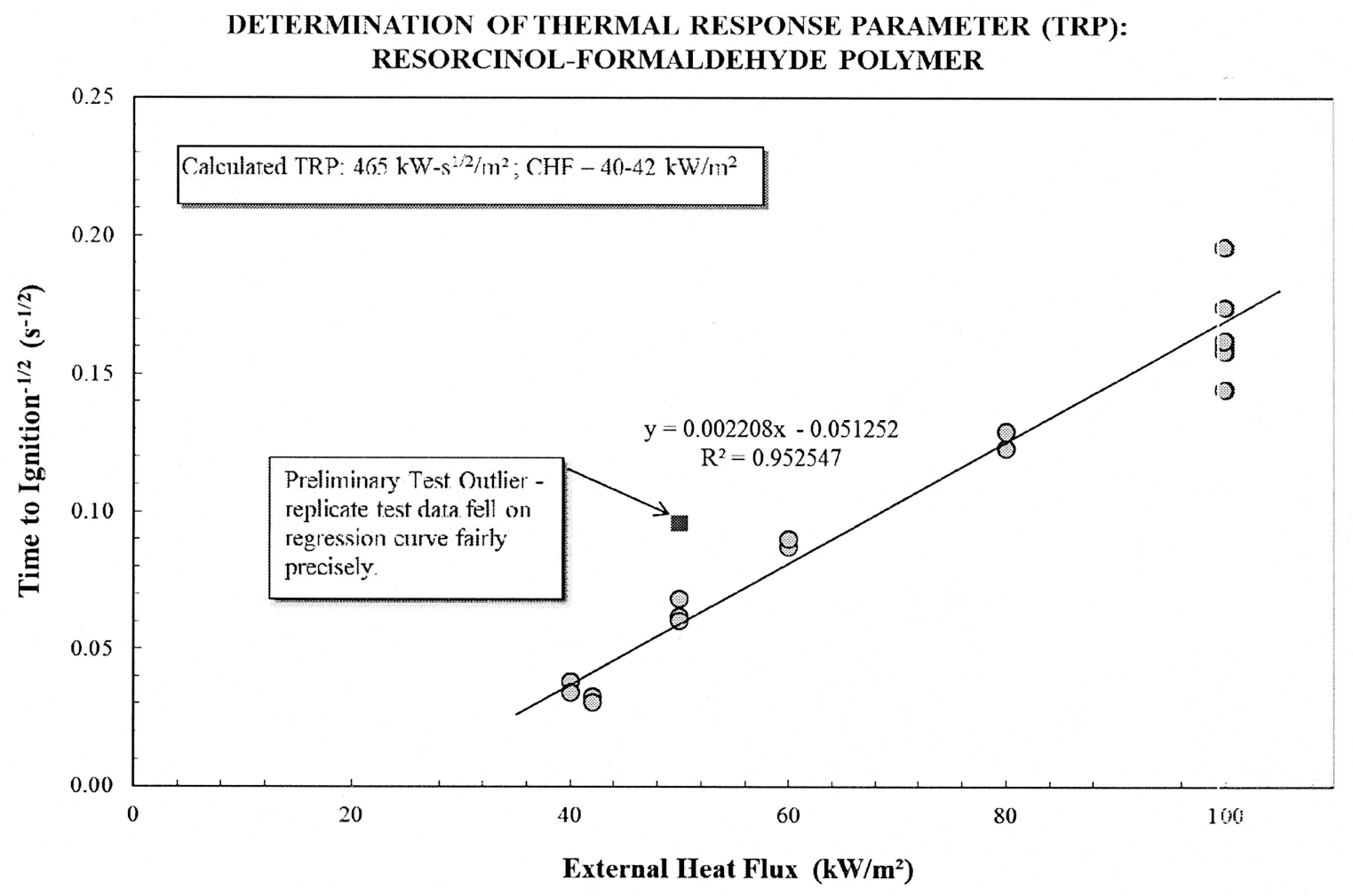

Figure 1. Plot of Ignition Data to Determine the TRP.

\subsection{CONE CALORIMETER}

For organic solids, liquids, and gases, a nearly constant net amount of heat is released per unit mass of oxygen consumed for complete combustion. An average value for this constant of 13.1 $\mathrm{MJ} / \mathrm{kg}$ of $\mathrm{O}_{2}$ can be used for practical applications and is accurate with very few exceptions to within $\pm 5 \%$. Therefore, measurements of the oxygen consumed in a combustion system can be used to determine the net heat released. This technique, generally referred to as the "oxygen consumption technique", is now the most widely used and accurate method for measuring heat release rate in experimental fires.

The Cone Calorimeter is a sophisticated small-scale test apparatus, which measures the rate of heat release of materials and products under a wide range of conditions using the oxygen consumption technique. A schematic of the instrument is shown in Figure 2. Other useful information obtained from Cone Calorimeter tests includes time to ignition, mass loss rate, smoke production rate, and effective heat of combustion.

In the Cone Calorimeter, a square sample measuring $100 \times 100 \mathrm{~mm}(4 \times 4 \mathrm{in}$.) is exposed to the radiant flux of an electric heater. The heater is in the shape of a truncated cone and is capable of providing heat fluxes to the specimen in the range of $0-100 \mathrm{~kW} / \mathrm{m}^{2}$. An electric spark igniter is used for piloted ignition of the pyrolysis gases produced by the radiant heater. 


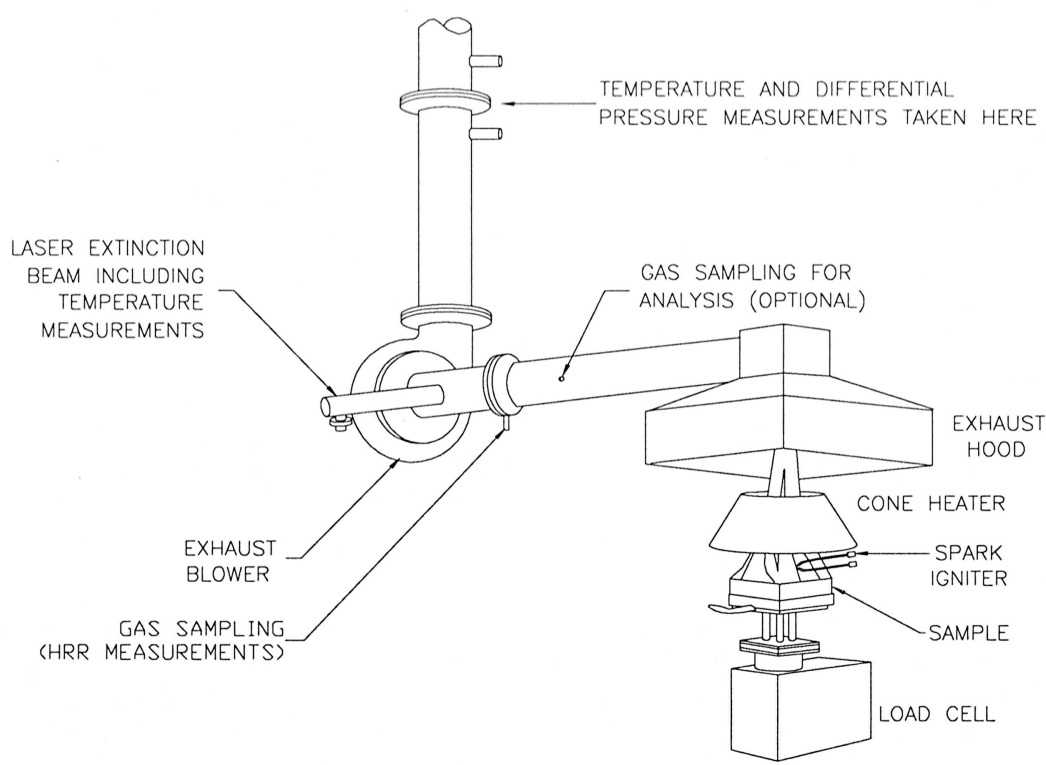

Figure 2. Schematic of the Cone Calorimeter Apparatus.

Test specimens are to be representative of the product's end use and can have a maximum thickness of $50 \mathrm{~mm}(2 \mathrm{in}$.). Specimens with a thickness of less than $6 \mathrm{~mm}$ are to be tested using a substrate that is representative of end-use conditions. Prior to testing, the test specimen is wrapped in aluminum foil, backed with a layer of low-density refractory fiber blanket, and placed in a standard specimen holder. An optional edge frame can be used to retain the sample within the specimen holder during testing. A load cell is used to measure the mass loss of the specimen throughout the duration of the test.

At the start of a test, the specimen (in the appropriate holder) is placed on the load cell, which is located below the heater. The top edge of the specimen is typically positioned $25 \mathrm{~mm}$ below the base plate of the heater. The electric spark igniter is located $13 \mathrm{~mm}$ above the center of the specimen. Four seconds after the pyrolysis gases released by the specimen ignite; the electric spark igniter is removed.

The products of combustion and entrained air are collected in a hood and extracted through an exhaust duct by a fan. A gas sample is drawn from the exhaust duct and analyzed for oxygen concentration. The gas temperature and differential pressure across an orifice plate are used for calculating the mass flow rate of the exhaust gases. Smoke production is determined based on the measured light obscuration in the duct using a laser photometer located close to the gas sampling point.

The Cone Calorimeter apparatus, calibration procedure, and test protocol are standardized in the United States as ASTM E 1354-10 and NFPA 271:2009, Standard Test Method for Heat and Visible Smoke Release Rates for Materials and Products Using an Oxygen Consumption Calorimeter and internationally as ISO 5660-1:2002, Fire tests-Reaction to fire-Part 1: Rate of heat release from building products--(Cone calorimeter method). ASTM E 1354 and NFPA 271 are functionally 
identical. SwRI's Cone Calorimeter is capable of performing tests in accordance with the ASTM, NFPA, and ISO standards.

Although the test procedure is prescribed in the ASTM, NFPA, and ISO standards, the standards do not specify operating parameters such as heat flux, specimen orientation, use of retainer frame and grid, etc. The choice of a suitable set of parameters is a function of the type and application of the product being tested. These parameters are usually specified by the Client, and are described in Section 4.0 of this report.

\subsection{DESCRIPTION OF TEST SPECIMENS}

Battelle Memorial Institute provided a material identified as Resorcinol-Formaldehyde Polymer for testing in accordance with ASTM E 1354-10. See Table 4 for the test sample description provided by the Client. SwRI received one 10 liter bottle of specimen described in the table below on November 23 and 28, 2011, and December 1 and 3, 2011.

Table 4. Test Sample Identification Description as Provided by Battelle Memorial Institute.

\begin{tabular}{|c|c|c|}
\hline Material ID & Description & Color \\
\hline $\begin{array}{c}\text { Resorcinol- } \\
\text { Formaldehyde } \\
\text { Polymer }\end{array}$ & Micro Beads & Red \\
\hline
\end{tabular}

Specimen preparation was in accordance with ASTM E 1354-10. The samples provided consisted of a micro bead material dispersed in water. The material was tested in worst case scenario, which is with the water removed. This process was achieved by first filtering the material, and then drying it in an oven. The sample was dried for a minimum of $10 \mathrm{~h}$ at $60^{\circ} \mathrm{C} \pm 3^{\circ} \mathrm{C}\left(140{ }^{\circ} \mathrm{F} \pm 5^{\circ} \mathrm{F}\right)$ prior to testing. After drying, the sample consisted of only the micro bead material; the beads became statically charged in the absence of the water medium and therefore, they were placed in a closed container after drying, in an effort not to lose any beads. Each sample was then conditioned in a controlled environment maintained at $23{ }^{\circ} \mathrm{C} \pm 3{ }^{\circ} \mathrm{C}$ and $50 \% \pm 5 \%$ relative humidity until just prior to testing.

\subsection{TEST PROCEDURE}

The critical heat flux of the material was determined by samples exposed to a fixed heat flux for a period of $10 \mathrm{~min}$. If the sample ignited, the heat flux was decreased, and the test repeated. If the sample did not ignite, the heat flux was increased and the test repeated. This process was repeated until the critical heat flux was determined to within $\pm 0.5 \mathrm{~kW} / \mathrm{m}^{2}$. The Resorcinol-Formaldehyde Polymer, using the ASTM E 1354 standard, had a heat flux of $42 \mathrm{~kW} / \mathrm{m}^{2}$. For the characterization of Resorcinol-Formaldehyde Polymer, using additional thermocouples in the specimens, you may refer to the Appendix. 


\section{TEST RESULTS}

Testing was conducted at SwRI's Fire Technology Department located in San Antonio, Texas, on November 12, 2011, and December 1 and 3, 2011. Heat release, mass loss, and smoke production data (SPR, SR 1 , and TSR) are calculated. The Resorcinol-Formaldehyde Polymer, using the ASTME 1354 standard, had a heat flux of $42 \mathrm{KW} / \mathrm{m}^{2}$. For the characterization of ResorcinolFormaldehyde Polymer, using additional thermocouples in the specimens, you may refer to Appendix A.

The following terms and abbreviations are used:

- $\mathrm{t}_{\mathrm{ig}}$

- Test Duration

- C-Factor

- $\mathrm{HRR}_{\text {peak }}$

- $\mathrm{HRR}_{60 \mathrm{~s}}$

- $\mathrm{HRR}_{180 \mathrm{~s}}$

- $\mathrm{HRR}_{300 \mathrm{~s}}$

- $\mathrm{HRR}_{30 \mathrm{~s}, \max }$

- Initial Mass
- THR

time to ignition/sustained flaming (flame over specimen surface for at least $4 \mathrm{~s}$ )

total test duration (time from the start of test until any flaming or other signs of combustion cease, the average mass loss over a 1-min period has dropped below $150 \mathrm{~g} / \mathrm{m}^{2}$, or until $60 \mathrm{~min}$ have elapsed)

calibration constant for oxygen consumption analysis $\left(\mathrm{m}^{1 / 2}-\mathrm{kg}^{1 / 2}-K^{1 / 2}\right)$

maximum value of the heat release rate per unit area $\left(\mathrm{kW} / \mathrm{m}^{2}\right)$

total amount of heat released per square meter $\left(\mathrm{MJ} / \mathrm{m}^{2}\right)$

average heat release rate over the first $60 \mathrm{~s}(1 \mathrm{~min})$ after ignition

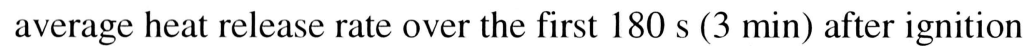

average heat release rate over the first $300 \mathrm{~s}(5 \mathrm{~min})$ after ignition

the maximum 30 -s sliding average of the heat release rate per unit area $\left(\mathrm{kW} / \mathrm{m}^{2}\right)$

the initial mass of the test specimen, prior to testing $(\mathrm{g})$

- Mass at Ignition the mass of the test specimen at the time of sustained ignition $(\mathrm{g})$

- Final Mass

the mass of the test specimen at the end of the test $(\mathrm{g})$

- $\quad$ Mass Loss

- MLR total specimen mass loss over the test $\left(\mathrm{g} / \mathrm{m}^{2}\right)$

average specimen mass loss rate per unit area $\left(\mathrm{g} / \mathrm{m}^{2} \cdot \mathrm{s}\right)$ computed over the test duration

- $\quad$ 10-90 MLR

average specimen mass loss rate per unit area $\left(\mathrm{g} / \mathrm{m}^{2} \cdot \mathrm{s}\right)$ computed over the period starting when $10 \%$ of the specimen mass loss occurred and ending when $90 \%$ of the specimen mass loss occurred

- $\mathrm{EHC}$

- $\mathrm{S}_{\mathrm{A} .1}$

- $\mathrm{S}_{\mathrm{A} .2}$

- $\mathrm{S}_{\mathrm{A}}$

- SEA effective heat of combustion (the ratio of heat release rate to mass loss rate$\mathrm{MJ} / \mathrm{kg}$ ) averaged over the test duration or the entire test if ignition does not occur smoke production per unit area of exposed specimen $\left(\mathrm{m}^{2} / \mathrm{m}^{2}\right)$ prior to ignition smoke production per unit area of exposed specimen $\left(\mathrm{m}^{2} / \mathrm{m}^{2}\right)$ from ignition until flameout or the end of the test; equal to zero if ignition does not occur

total smoke production per unit area of exposed specimen during the test duration $\left(\mathrm{S}_{\mathrm{A}, 1}+\mathrm{S}_{\mathrm{A}, 2}\right)$

specific smoke extinction area (the ratio of smoke production to specimen mass loss $-\mathrm{m}^{2} / \mathrm{kg}$ ) averaged over the test duration. 
APpendix A

\section{CONE CALORIMETER DATA}

(Consisting of 13 Pages) 


\section{CONE CALORIMETER TEST REPORT}

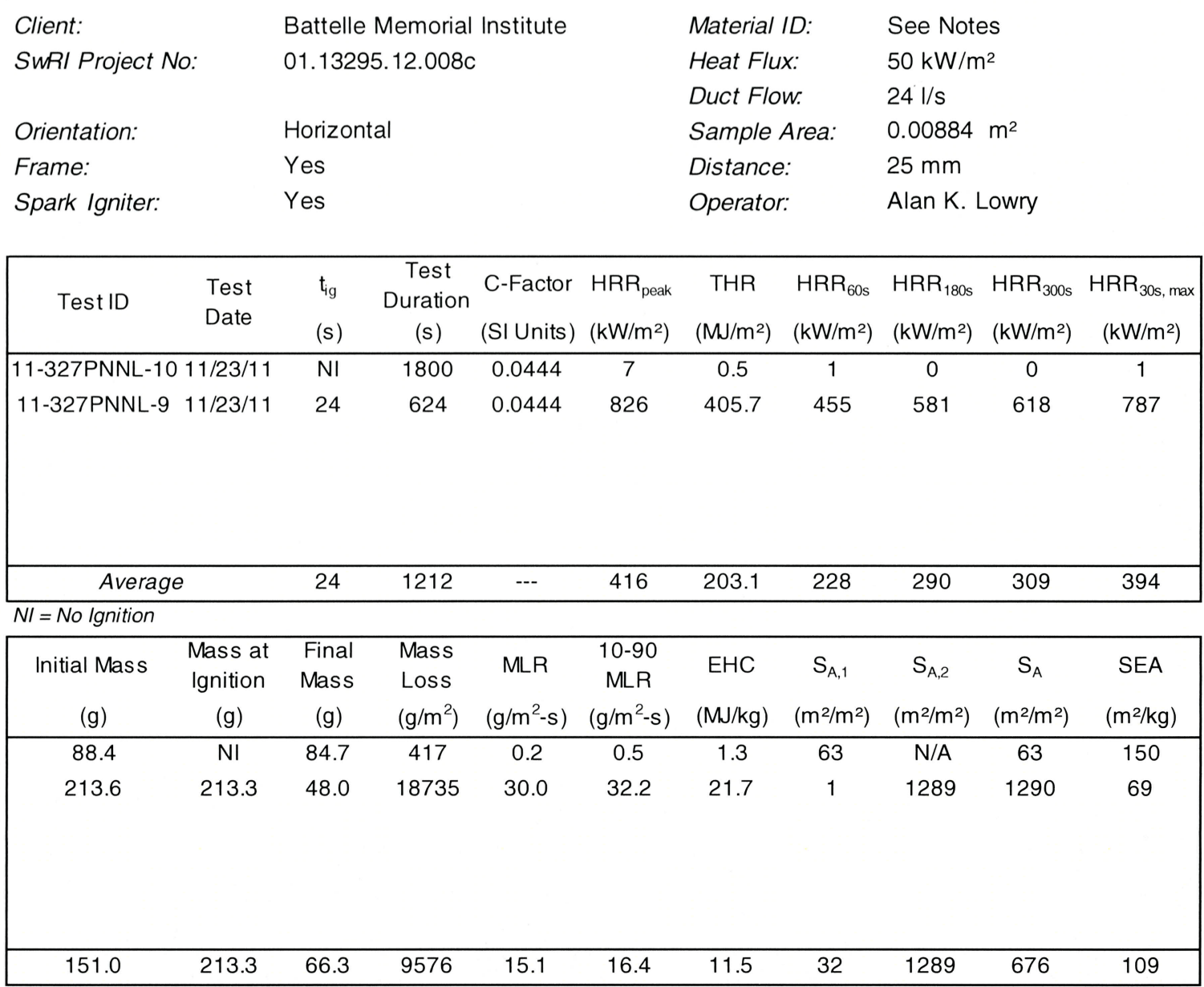

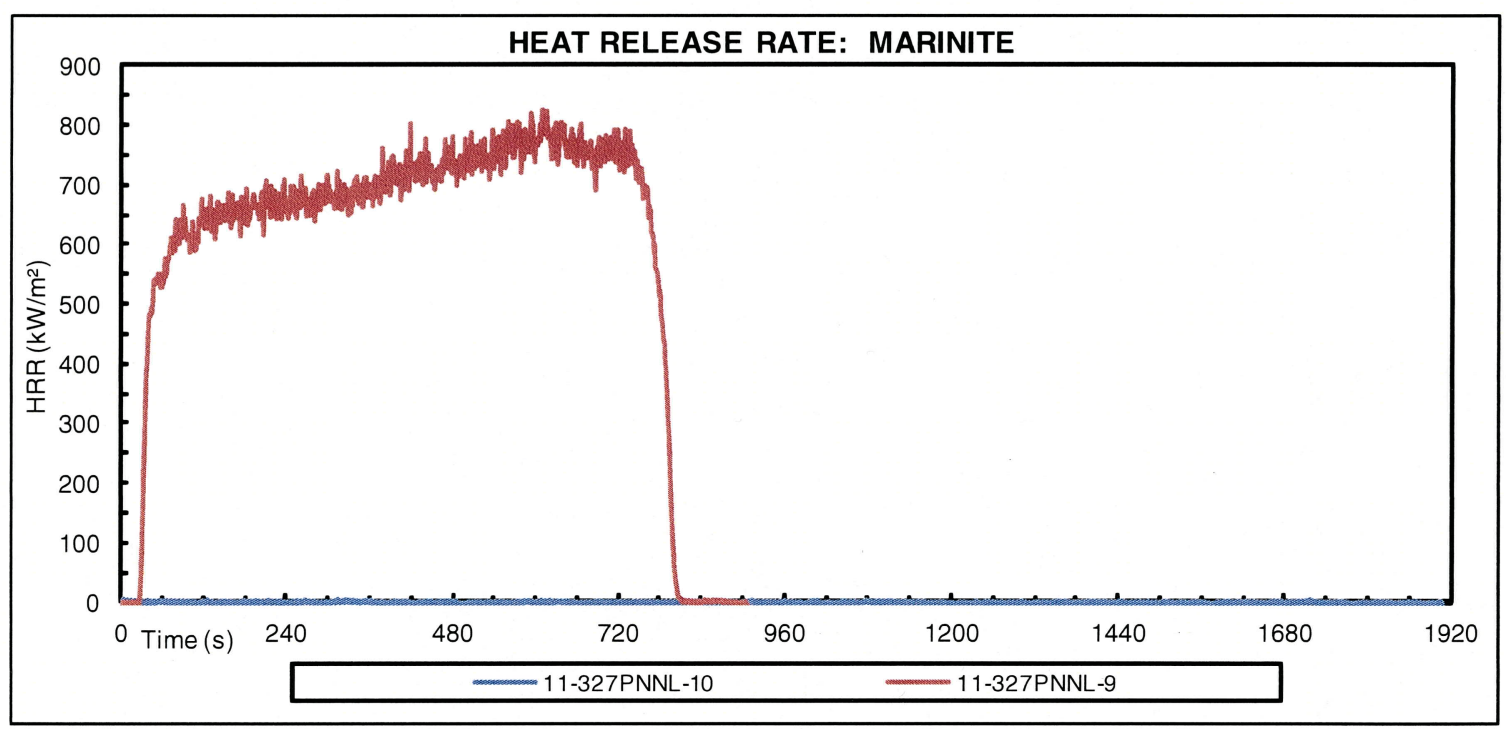




\section{CONE CALORIMETER TEST REPORT}

$\begin{array}{llll}\text { Client: } & \text { Battelle Memorial Institute } & \text { Material ID: } & \text { See Notes } \\ \text { SwRI Project No: } & \text { 01.13295.12.008c } & \text { Heat Flux: } & 50 \mathrm{~kW} / \mathrm{m}^{2}\end{array}$

(Page 2)
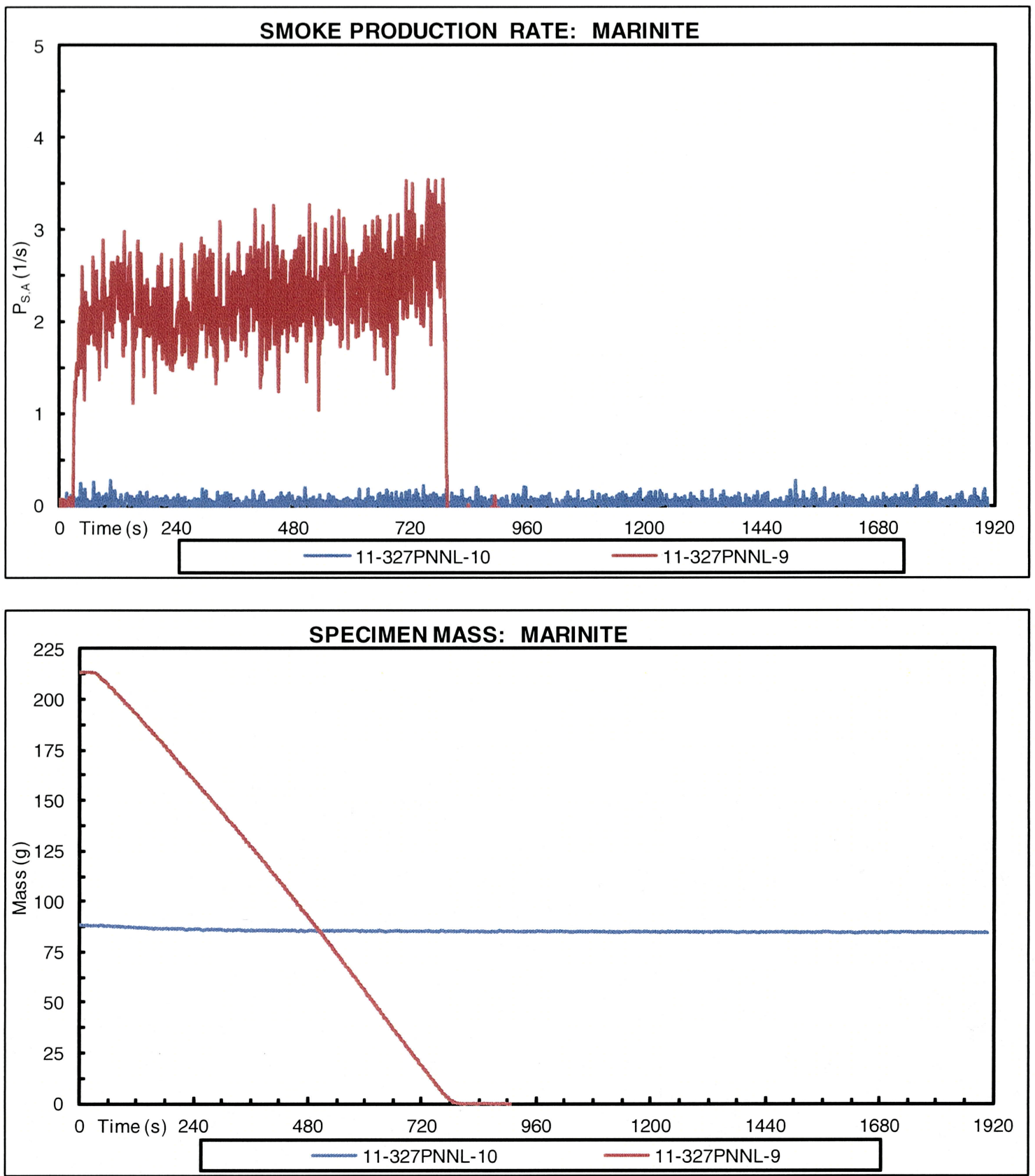

Notes \& Observations:

11-327PNNL-9 PMMA Standard

11-327PNNL-10 Marinite Standard 


\section{CONE CALORIMETER TEST REPORT}

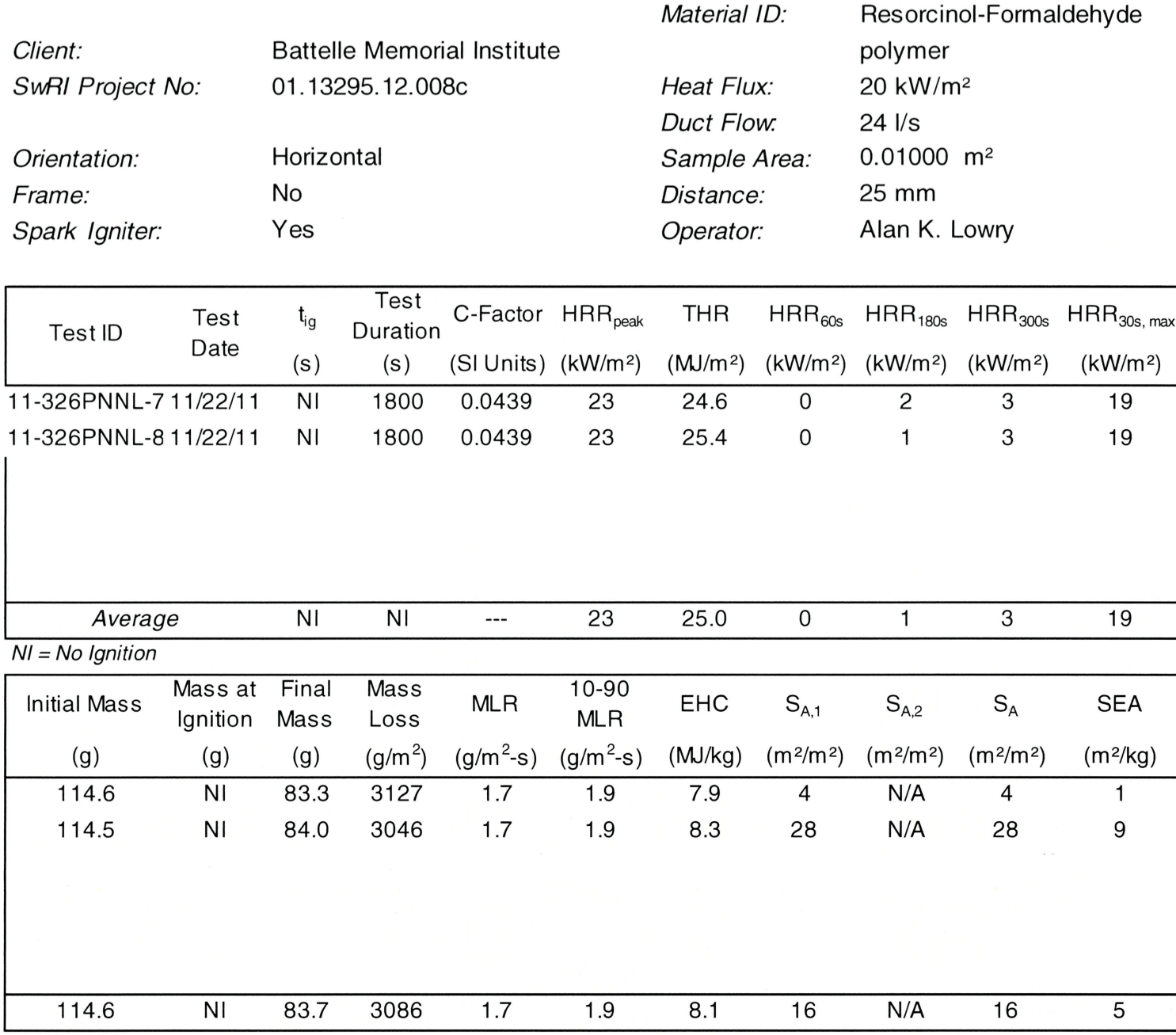

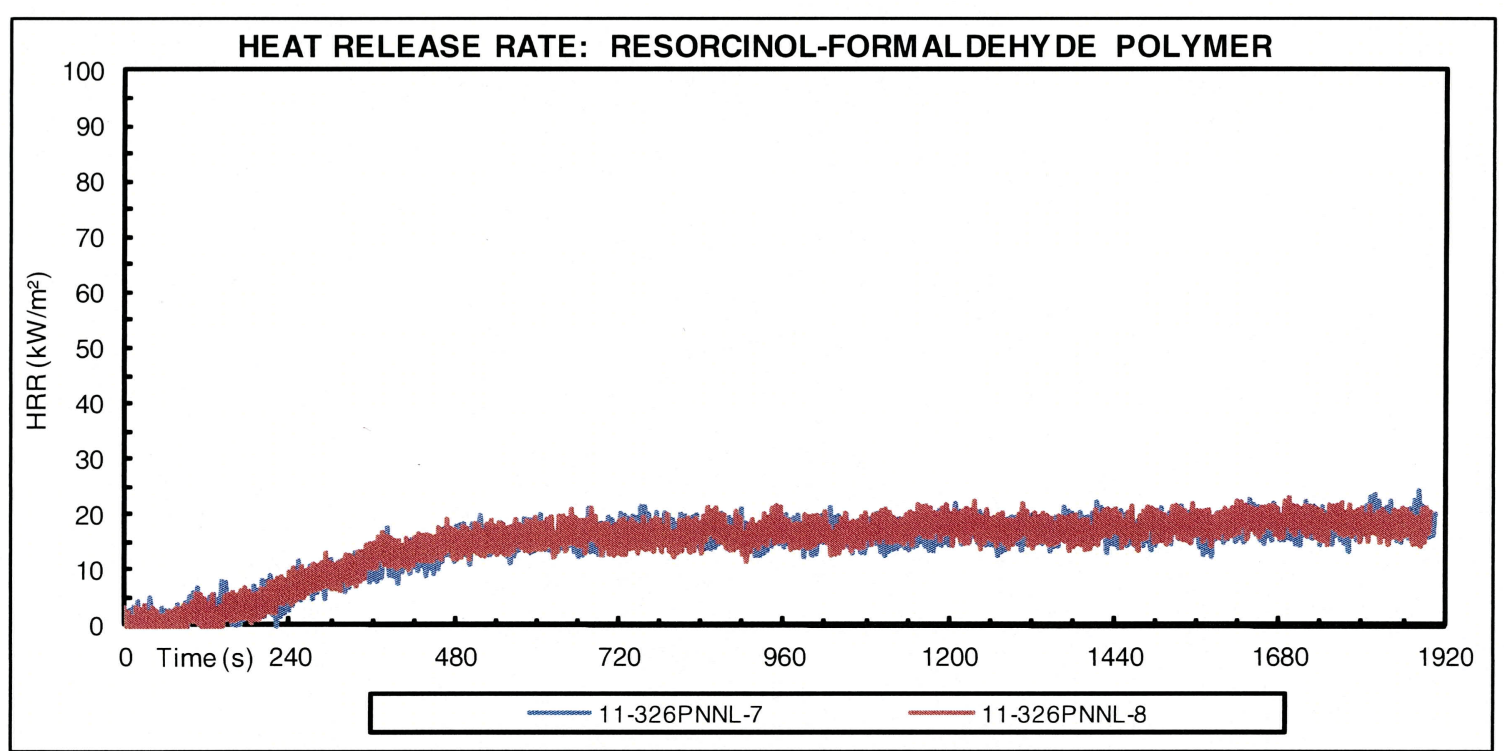




\section{CONE CALORIMETER TEST REPORT}

Client:

Battelle Memorial Institute

SwRI Project No: 01.13295.12.008c
Material ID:

Resorcinol-Formaldehyde

polymer

Heat Flux: $\quad 20 \mathrm{~kW} / \mathrm{m}^{2}$

(Page 2)
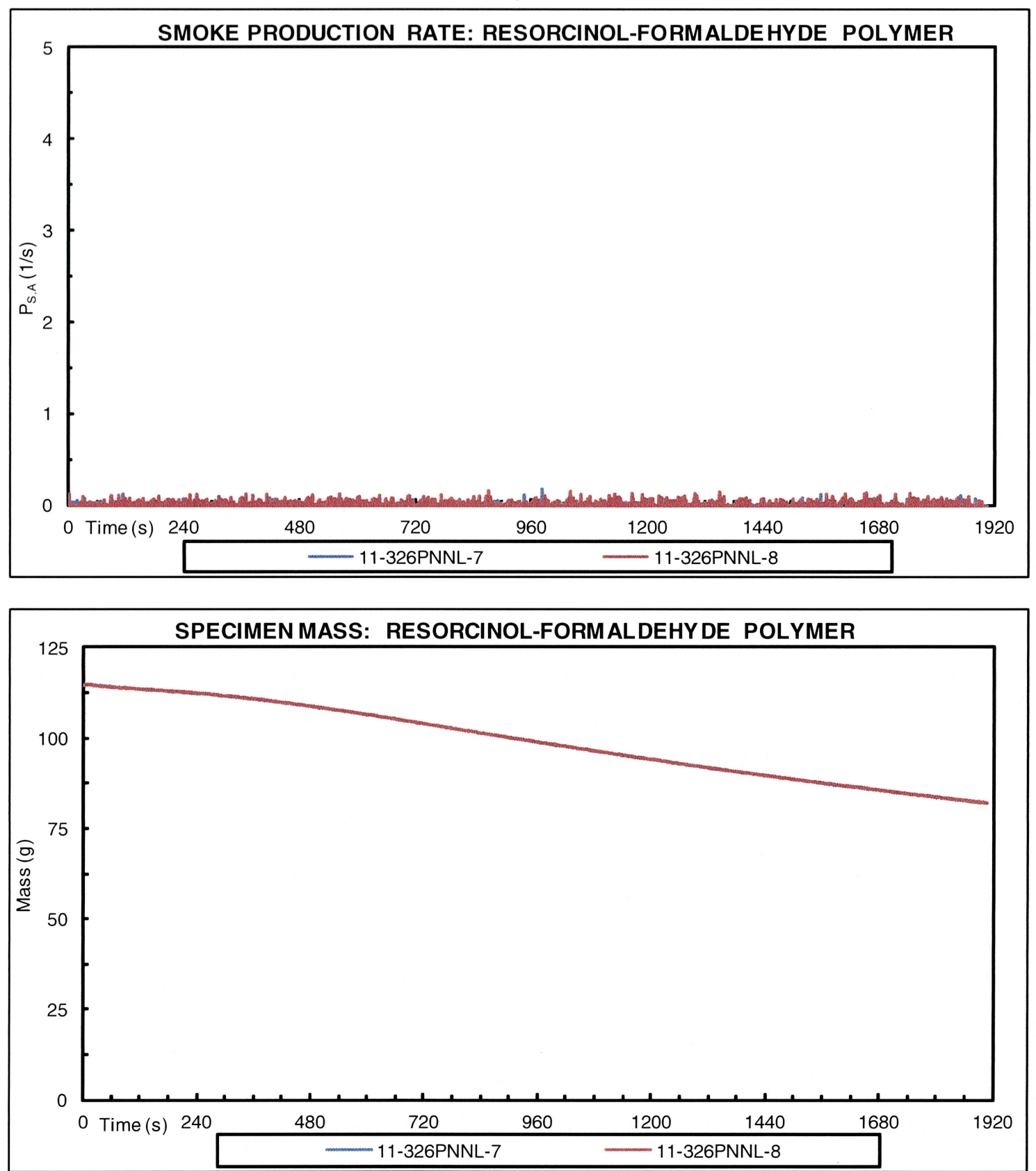

Notes \& Observations:

11-326PNNL-7 Regular Run

11-326PNNL-8 Duplicate Run 


\section{CONE CALORIMETER TEST REPORT}

Client:

SwRI Project No:

Battelle Memorial Institute

$01.13295 .12 .008 \mathrm{c}$

Orientation:

Frame:

Horizontal

Spark Igniter:
No

Yes
Material ID:

Resorcinol-Formaldehyde

polymer

Heat Flux: $\quad 40 \mathrm{~kW} / \mathrm{m}^{2}$

Duct Flow. $\quad 24 \mathrm{l} / \mathrm{s}$

Sample Area: $\quad 0.01000 \mathrm{~m}^{2}$

Distance: $\quad 25 \mathrm{~mm}$

Operator: Alan K. Lowry

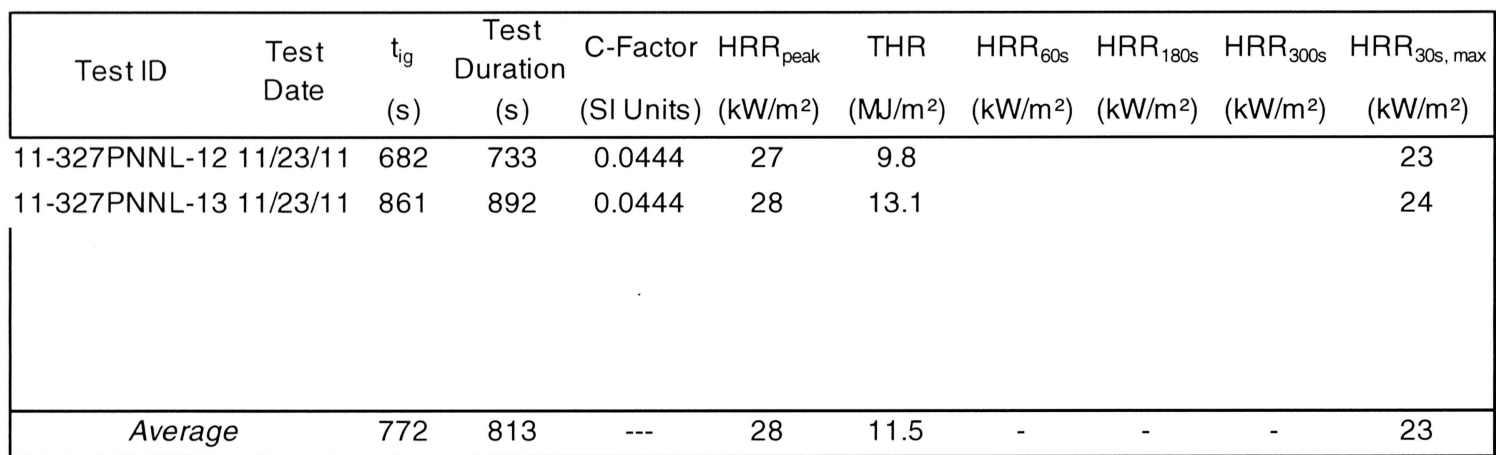

\begin{tabular}{|c|c|c|c|c|c|c|c|c|c|c|}
\hline $\begin{array}{c}\text { Initial Mass } \\
\text { (g) }\end{array}$ & $\begin{array}{c}\text { Mass at } \\
\text { Ignition } \\
\text { (g) }\end{array}$ & $\begin{array}{c}\text { Final } \\
\text { Mass } \\
(\mathrm{g})\end{array}$ & $\begin{array}{l}\text { Mass } \\
\text { Loss } \\
\left(\mathrm{g} / \mathrm{m}^{2}\right)\end{array}$ & $\begin{array}{c}M L R \\
\left(g / m^{2}-s\right)\end{array}$ & $\begin{array}{c}10-90 \\
\text { MLR } \\
\left(\mathrm{g} / \mathrm{m}^{2}-\mathrm{s}\right)\end{array}$ & $\begin{array}{c}\text { EHC } \\
(\mathrm{MJ} / \mathrm{kg})\end{array}$ & $\begin{array}{c}S_{A, 1} \\
\left(m^{2} / m^{2}\right)\end{array}$ & $\begin{array}{c}S_{A, 2} \\
\left(m^{2} / m^{2}\right)\end{array}$ & 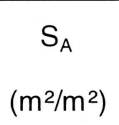 & $\begin{array}{l}\text { SEA } \\
\left(\mathrm{m}^{2} / \mathrm{kg}\right)\end{array}$ \\
\hline 128.3 & 101.9 & 100.1 & 2816 & 3.9 & 3.8 & 3.5 & 2 & 0 & 2 & 0 \\
\hline 127.2 & 93.6 & 92.7 & 3446 & 3.9 & 3.9 & 3.8 & 23 & 1 & 24 & 0 \\
\hline 127.8 & 97.8 & 96.4 & 3131 & 3.9 & 3.8 & 3.6 & 12 & 0 & 13 & 0 \\
\hline
\end{tabular}

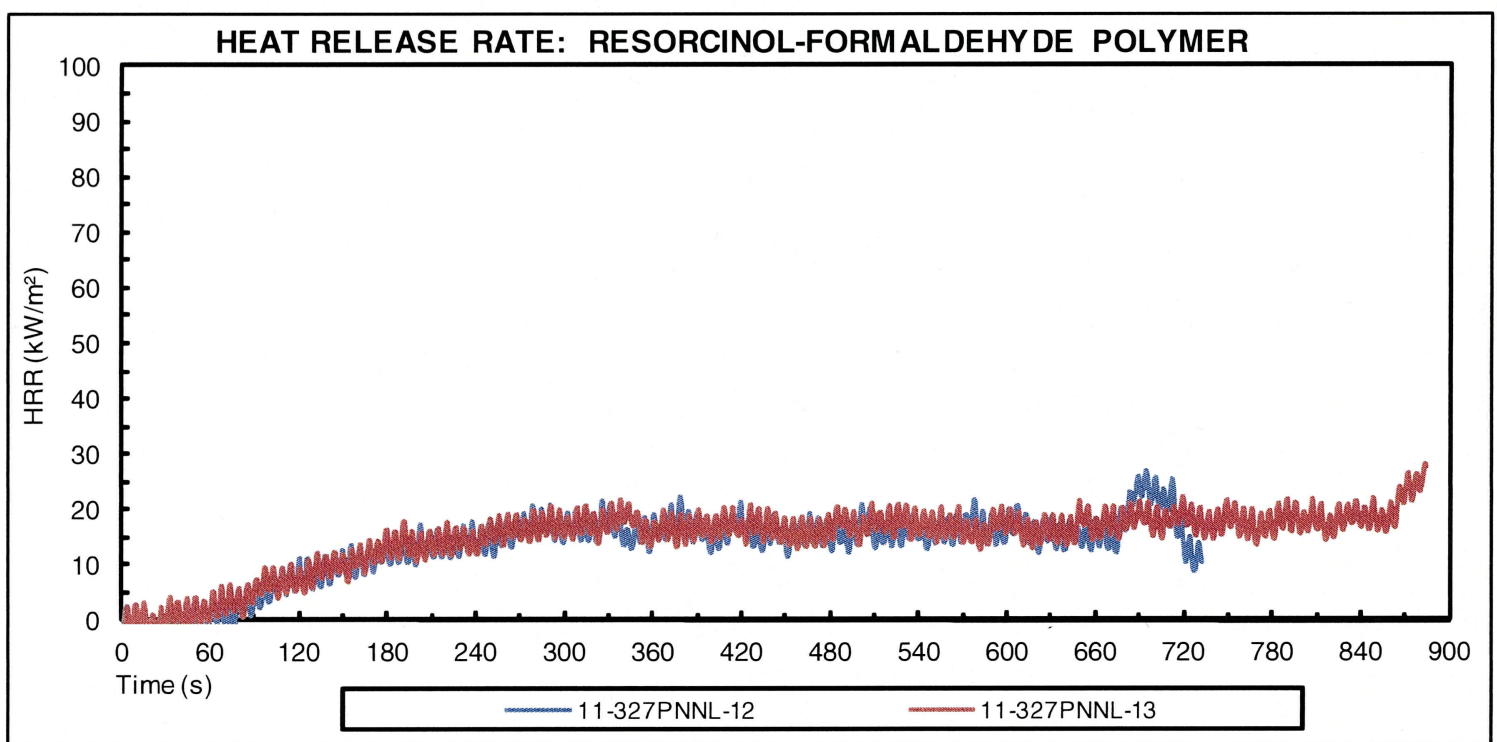




\section{CONE CALORIMETER TEST REPORT}

Client:

Battelle Memorial Institute

SwRI Project No: $01.13295 .12 .008 \mathrm{c}$
Material ID:

Resorcinol-Formaldehyde

polymer

Heat Flux: $\quad 40 \mathrm{~kW} / \mathrm{m}^{2}$

(Page 2)
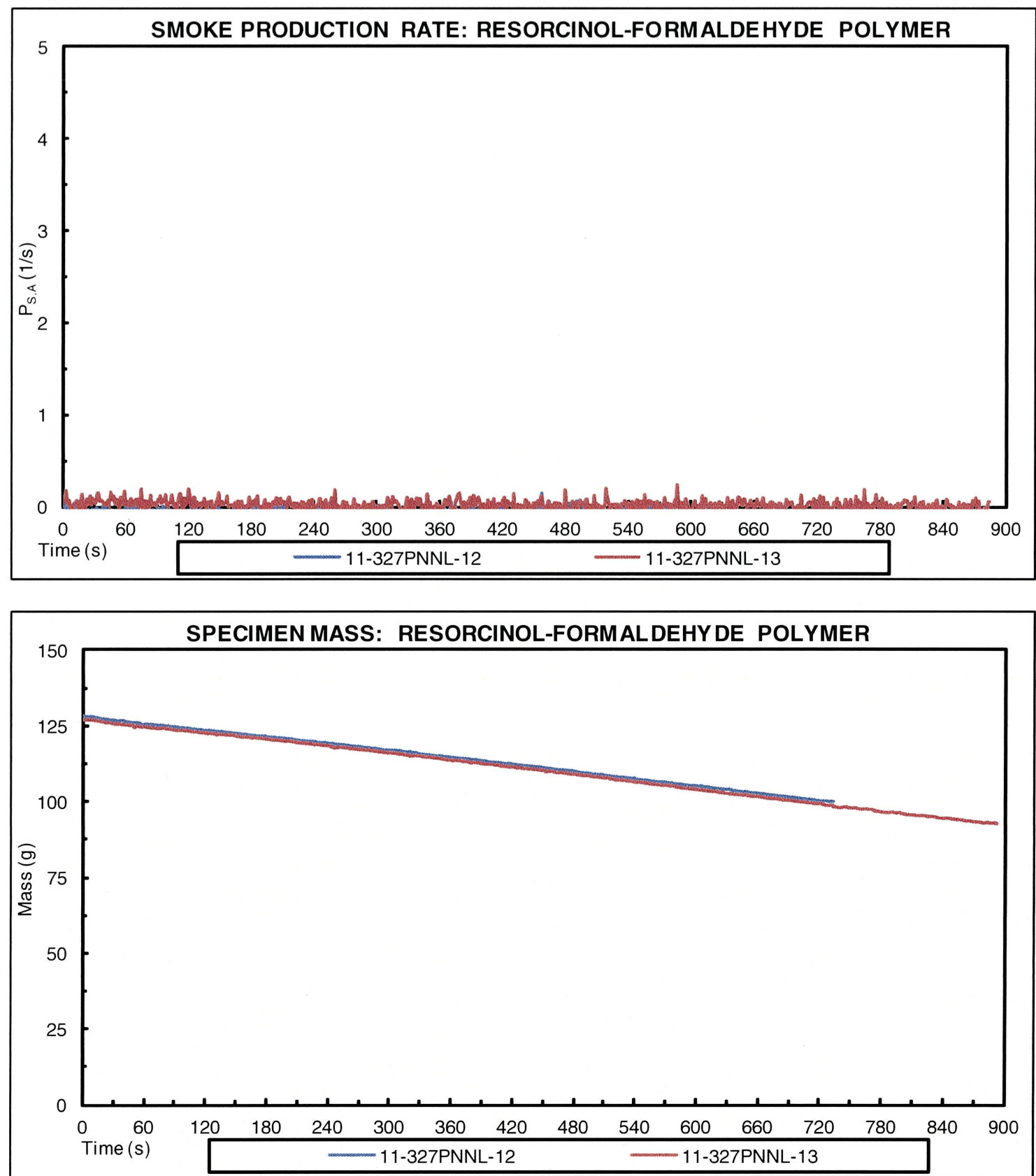

Notes \& Observations:

11-327PNNL-12 Regular Run

11-327PNNL-13 Duplicate Run 


\section{CONE CALORIMETER TEST REPORT}

$\begin{array}{llll} & \text { Battelle Memorial Institutec } & \text { Material ID: } & \begin{array}{l}\text { Resorcinol-Formaldehyde } \\ \text { plient: }\end{array} \\ \text { SwRI Project No: } & \text { 01.13295.12.008c } & \text { Heat Flux: } & 60 \mathrm{~kW} / \mathrm{m}^{2} \\ & & \text { Duct Flow: } & 24 \mathrm{l} / \mathrm{s} \\ \text { Orientation: } & \text { Horizontal } & \text { Sample Area: } & 0.01000 \mathrm{~m}^{2} \\ \text { Frame: } & \text { No } & \text { Distance: } & 25 \mathrm{~mm} \\ \text { Spark Igniter: } & \text { Yes } & \text { Operator: } & \text { Alan K. Lowry }\end{array}$

\begin{tabular}{|c|c|c|c|c|c|c|c|c|c|c|}
\hline Test ID & Test Date & $\begin{array}{l}t_{i g} \\
\text { (s) }\end{array}$ & $\begin{array}{c}\text { Test } \\
\text { Duration } \\
\text { (s) }\end{array}$ & $\begin{array}{l}\text { C-Factor } \\
\text { (SI Units) }\end{array}$ & $\begin{array}{l}\mathrm{HRR}_{\text {peak }} \\
\left(\mathrm{kW} / \mathrm{m}^{2}\right)\end{array}$ & $\begin{array}{c}\text { THR } \\
\left(\mathrm{MV} / \mathrm{m}^{2}\right)\end{array}$ & $\begin{array}{l}\mathrm{HRR}_{60 \mathrm{~s}} \\
\left(\mathrm{~kW} / \mathrm{m}^{2}\right)\end{array}$ & $\begin{array}{l}\mathrm{HRR}_{180 \mathrm{~s}} \\
\left(\mathrm{~kW} / \mathrm{m}^{2}\right)\end{array}$ & $\begin{array}{l}\mathrm{HRR}_{300 \mathrm{~s}} \\
\left(\mathrm{~kW} / \mathrm{m}^{2}\right)\end{array}$ & $\begin{array}{c}\mathrm{HRR}_{30 \mathrm{~s}, \max } \\
\left(\mathrm{kW} / \mathrm{m}^{2}\right)\end{array}$ \\
\hline 11-327PNNL-14 & $11 / 23 / 11$ & 132 & 172 & 0.0444 & 35 & 1.9 & & & & 28 \\
\hline 11-327PNNL-15 & $11 / 23 / 11$ & 123 & 132 & 0.0444 & 26 & 1.2 & & & & 19 \\
\hline Averag & & 128 & 152 & --- & 30 & 1.6 & - & - & - & 23 \\
\hline
\end{tabular}

\begin{tabular}{|c|c|c|c|c|c|c|c|c|c|c|}
\hline $\begin{array}{c}\text { Initial Mass } \\
\text { (g) }\end{array}$ & $\begin{array}{c}\text { Mass at } \\
\text { Ignition } \\
\text { (g) }\end{array}$ & $\begin{array}{c}\text { Final } \\
\text { Mass } \\
(\mathrm{g})\end{array}$ & $\begin{array}{l}\text { Mass } \\
\text { Loss } \\
\left(\mathrm{g} / \mathrm{m}^{2}\right)\end{array}$ & $\begin{array}{c}\text { MLR } \\
\left(\mathrm{g} / \mathrm{m}^{2}-\mathrm{s}\right)\end{array}$ & $\begin{array}{c}10-90 \\
\text { MLR } \\
\left(\mathrm{g} / \mathrm{m}^{2}-\mathrm{s}\right)\end{array}$ & $\begin{array}{c}\text { EHC } \\
(\mathrm{MJ} / \mathrm{kg})\end{array}$ & $\begin{array}{c}\mathrm{S}_{\mathrm{A}, 1} \\
\left(\mathrm{~m}^{2} / \mathrm{m}^{2}\right)\end{array}$ & $\begin{array}{c}\mathrm{S}_{\mathrm{A}, 2} \\
\left(\mathrm{~m}^{2} / \mathrm{m}^{2}\right)\end{array}$ & $\begin{array}{c}\mathrm{S}_{\mathrm{A}} \\
\left(\mathrm{m}^{2} / \mathrm{m}^{2}\right)\end{array}$ & $\begin{array}{c}\text { SEA } \\
\left(\mathrm{m}^{2} / \mathrm{kg}\right)\end{array}$ \\
\hline 129.4 & 121.8 & 120.0 & 937 & 5.5 & 5.4 & 2.1 & 1 & 0 & 1 & 0 \\
\hline 126.0 & 118.1 & 117.8 & 819 & 6.2 & 6.1 & 1.5 & 1 & 0 & 2 & 0 \\
\hline 127.7 & 120.0 & 118.9 & 878 & 5.9 & 5.7 & 1.8 & 1 & 0 & 1 & 0 \\
\hline
\end{tabular}

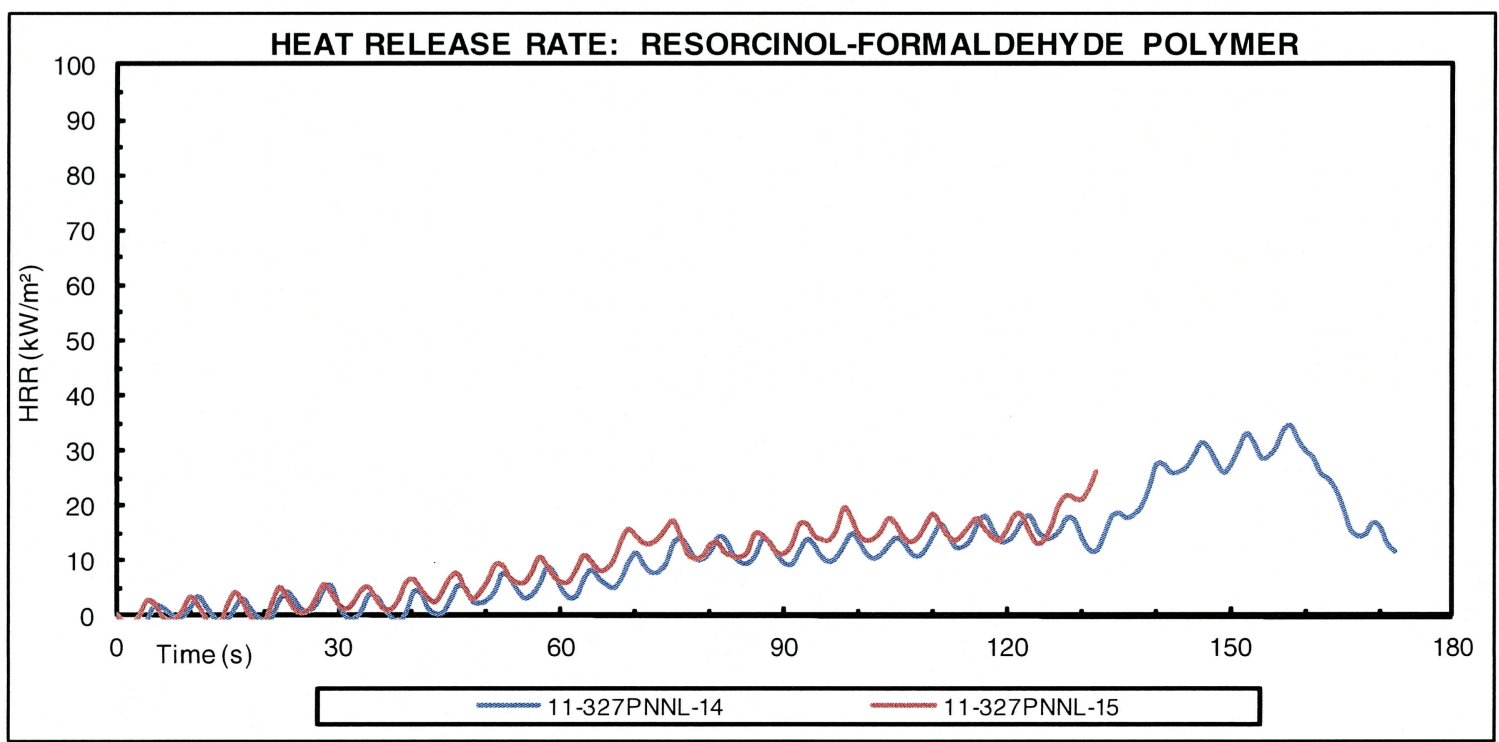




\section{CONE CALORIMETER TEST REPORT}

$\begin{array}{llll} & & \text { Material ID: } & \text { Resorcinol-Formaldehyde } \\ \text { Client: } & \text { Battelle Memorial Institute } & & \text { polymer } \\ \text { SwRI Project No: } 01.13295 .12 .008 \mathrm{c} & \text { Heat Flux: } & 60 \mathrm{~kW} / \mathrm{m}^{2}\end{array}$

(Page 2)
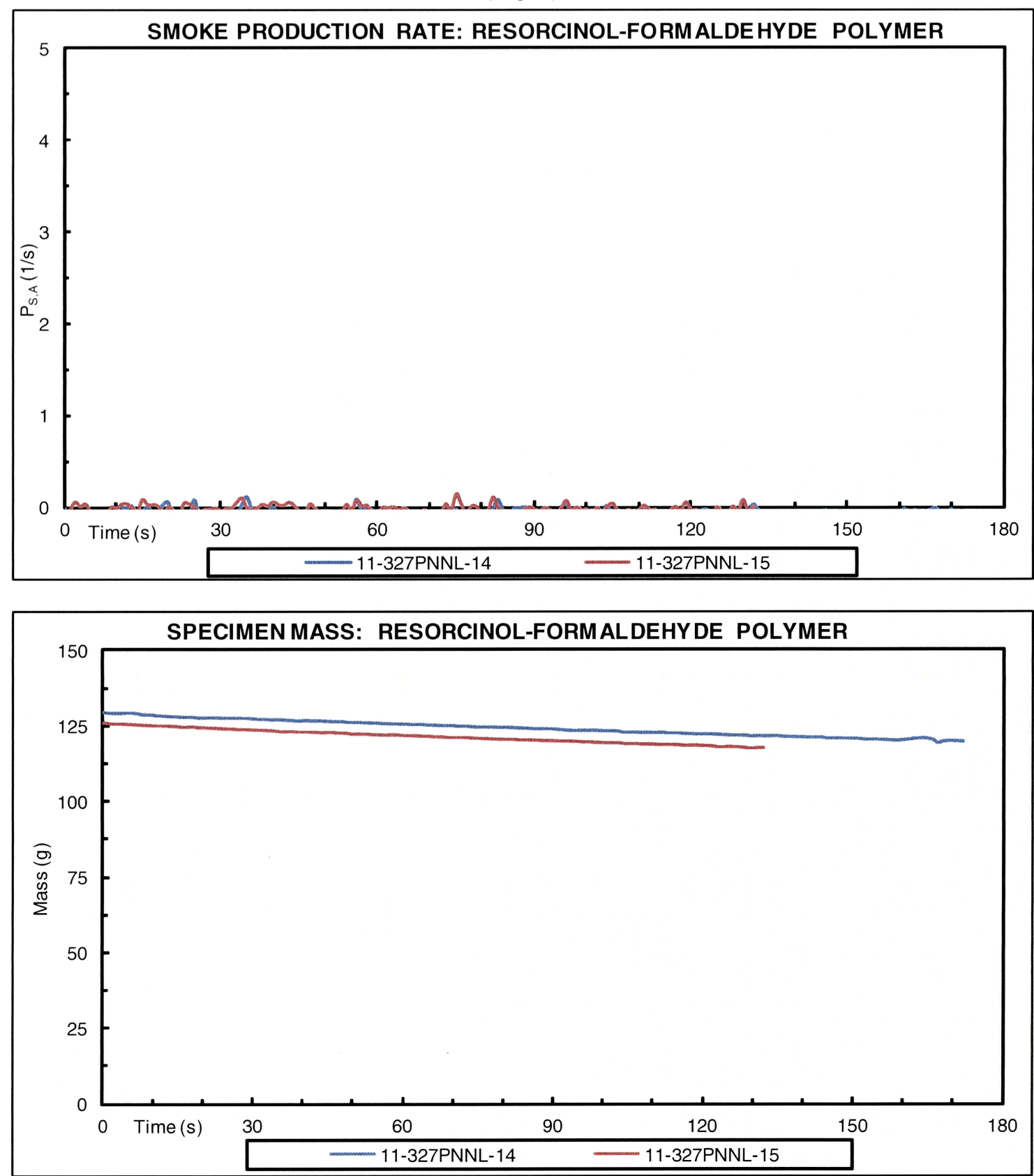

Notes \& Observations: 11-327PNNL-14 Regular Run

11-327PNNL-15 Duplicate Run 


\section{CONE CALORIMETER TEST REPORT}

\begin{tabular}{|c|c|c|c|c|c|c|c|c|c|}
\hline \multicolumn{2}{|l|}{ Client: } & \multicolumn{4}{|c|}{ Battelle Memorial Institute } & \multicolumn{2}{|c|}{ Material ID: } & \multicolumn{2}{|c|}{$\begin{array}{l}\text { Resorcinol-Formaldehyde } \\
\text { polymer }\end{array}$} \\
\hline \multirow{2}{*}{\multicolumn{2}{|c|}{ SwRI Project No: }} & \multicolumn{4}{|c|}{$01.13295 .12 .008 \mathrm{c}$} & \multicolumn{2}{|c|}{$\begin{array}{l}\text { Heat Flux: } \\
\text { Duct Flow: }\end{array}$} & \multicolumn{2}{|l|}{$80 \mathrm{~kW} / \mathrm{m}^{2}$} \\
\hline & & & & & & Duct Flo & & $24 \mathrm{l} / \mathrm{s}$ & \\
\hline Orientation: & & Horiz & ontal & & & Sample & Area: & $0.01000 \mathrm{~m}^{2}$ & \\
\hline Frame: & & No & & & & Distance & & $25 \mathrm{~mm}$ & \\
\hline Spark Igniter: & & Yes & & & & Operato & & Alan K. Lowry & \\
\hline Test ID & $\begin{array}{l}\text { Test } \\
\text { Date }\end{array}$ & $\begin{array}{l}t_{i g} \\
(s)\end{array}$ & $\begin{array}{c}\text { Test } \\
\text { Duration } \\
\text { (s) }\end{array}$ & $\begin{array}{l}\text { C-Factor } \\
\text { (SI Units) }\end{array}$ & $\begin{array}{l}\mathrm{HRR}_{\text {peak }} \\
\left(\mathrm{kW} / \mathrm{m}^{2}\right)\end{array}$ & $\begin{array}{c}\text { THR } \\
\left(\mathrm{MJ} / \mathrm{m}^{2}\right)\end{array}$ & $\begin{array}{l}\mathrm{HRR}_{60 \mathrm{~s}} \\
\left(\mathrm{~kW} / \mathrm{m}^{2}\right)\end{array}$ & $\begin{array}{ll}\mathrm{HRR}_{180 \mathrm{~s}} & \mathrm{HRR}_{300 \mathrm{~s}} \\
\left(\mathrm{~kW} / \mathrm{m}^{2}\right) & \left(\mathrm{kW} / \mathrm{m}^{2}\right)\end{array}$ & $\begin{array}{c}\mathrm{HRR}_{30 \mathrm{~s}, \max } \\
\left(\mathrm{kW} / \mathrm{m}^{2}\right)\end{array}$ \\
\hline 11-332PNNL-16 & $11 / 28 / 11$ & 66 & 123 & 0.0432 & 42 & 2.0 & - & & 36 \\
\hline 11-332PNNL-17 & $11 / 28 / 11$ & 60 & 100 & 0.0432 & 36 & 1.5 & - & & 33 \\
\hline Average & & 63 & 112 & --- & 39 & 1.8 & - & - & 34 \\
\hline
\end{tabular}

\begin{tabular}{|c|c|c|c|c|c|c|c|c|c|c|}
\hline $\begin{array}{c}\text { Initial Mass } \\
\text { (g) }\end{array}$ & $\begin{array}{l}\text { Mass at } \\
\text { Ignition } \\
\text { (g) }\end{array}$ & $\begin{array}{c}\text { Final } \\
\text { Mass } \\
(\mathrm{g})\end{array}$ & $\begin{array}{l}\text { Mass } \\
\text { Loss } \\
\left(\mathrm{g} / \mathrm{m}^{2}\right)\end{array}$ & $\begin{array}{c}\text { MLR } \\
\left(\mathrm{g} / \mathrm{m}^{2}-\mathrm{s}\right)\end{array}$ & $\begin{array}{c}10-90 \\
\text { MLR } \\
\left(\mathrm{g} / \mathrm{m}^{2}-\mathrm{s}\right)\end{array}$ & $\begin{array}{c}\mathrm{EHC} \\
(\mathrm{MJ} / \mathrm{kg})\end{array}$ & $\begin{array}{c}\mathrm{S}_{\mathrm{A}, 1} \\
\left(\mathrm{~m}^{2} / \mathrm{m}^{2}\right)\end{array}$ & $\begin{array}{c}\mathrm{S}_{\mathrm{A}, 2} \\
\left(\mathrm{~m}^{2} / \mathrm{m}^{2}\right)\end{array}$ & $\begin{array}{c}\mathrm{S}_{\mathrm{A}} \\
\left(\mathrm{m}^{2} / \mathrm{m}^{2}\right)\end{array}$ & $\begin{array}{c}\text { SEA } \\
\left(\mathrm{m}^{2} / \mathrm{kg}\right)\end{array}$ \\
\hline 125.2 & 120.4 & 118.0 & 719 & 5.9 & 7.1 & 2.7 & 2 & 2 & 4 & 3 \\
\hline 124.8 & 120.2 & 117.5 & 732 & 7.6 & 7.5 & 2.1 & 2 & 1 & 3 & 2 \\
\hline 125.0 & 120.3 & 117.7 & 725 & 6.8 & 7.3 & 2.4 & 2 & 2 & 4 & 2 \\
\hline
\end{tabular}

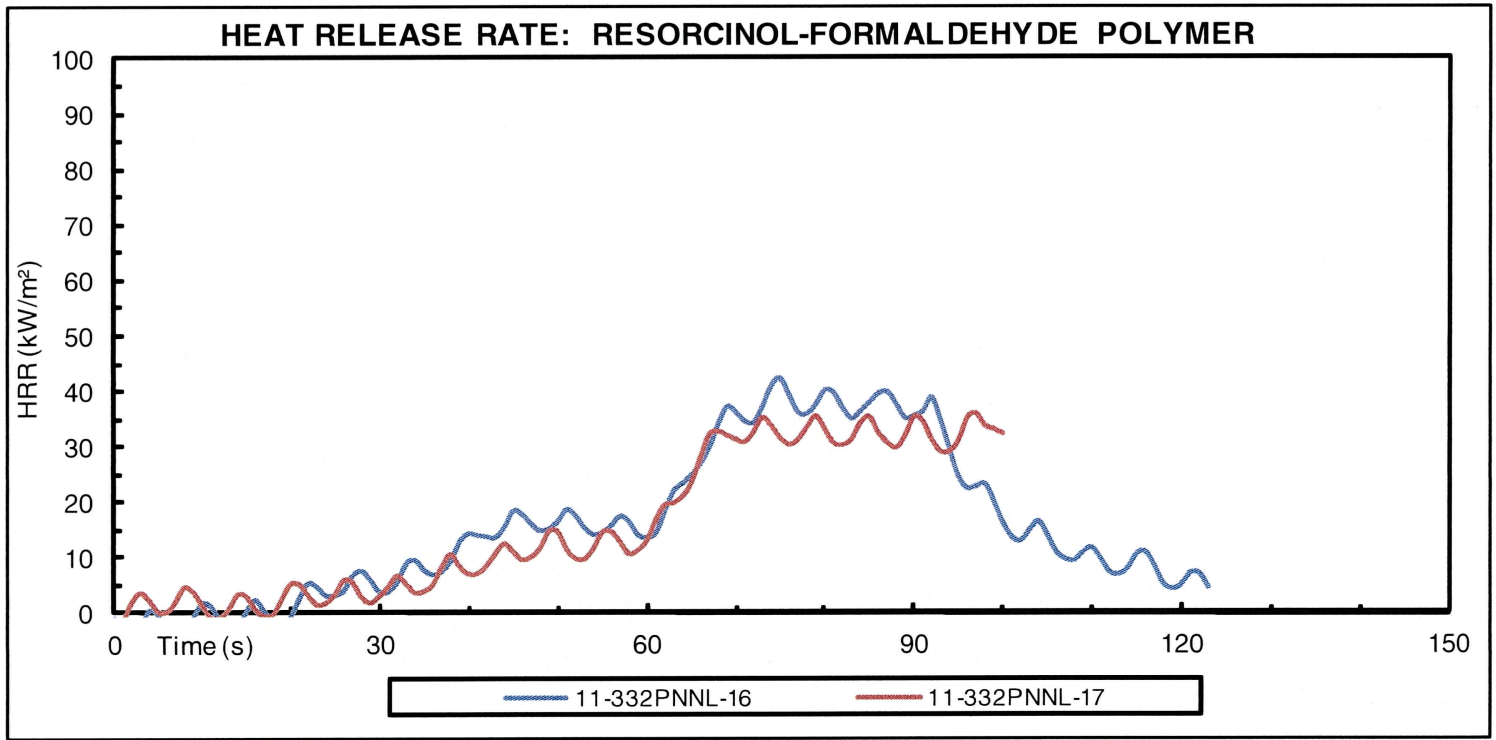




\section{CONE CALORIMETER TEST REPORT}

Client:

Battelle Memorial Institute

SwRI Project No: 01.13295.12.008c
Material ID:

Resorcinol-Formaldehyde

polymer

Heat Flux: $\quad 80 \mathrm{~kW} / \mathrm{m}^{2}$

(Page 2)
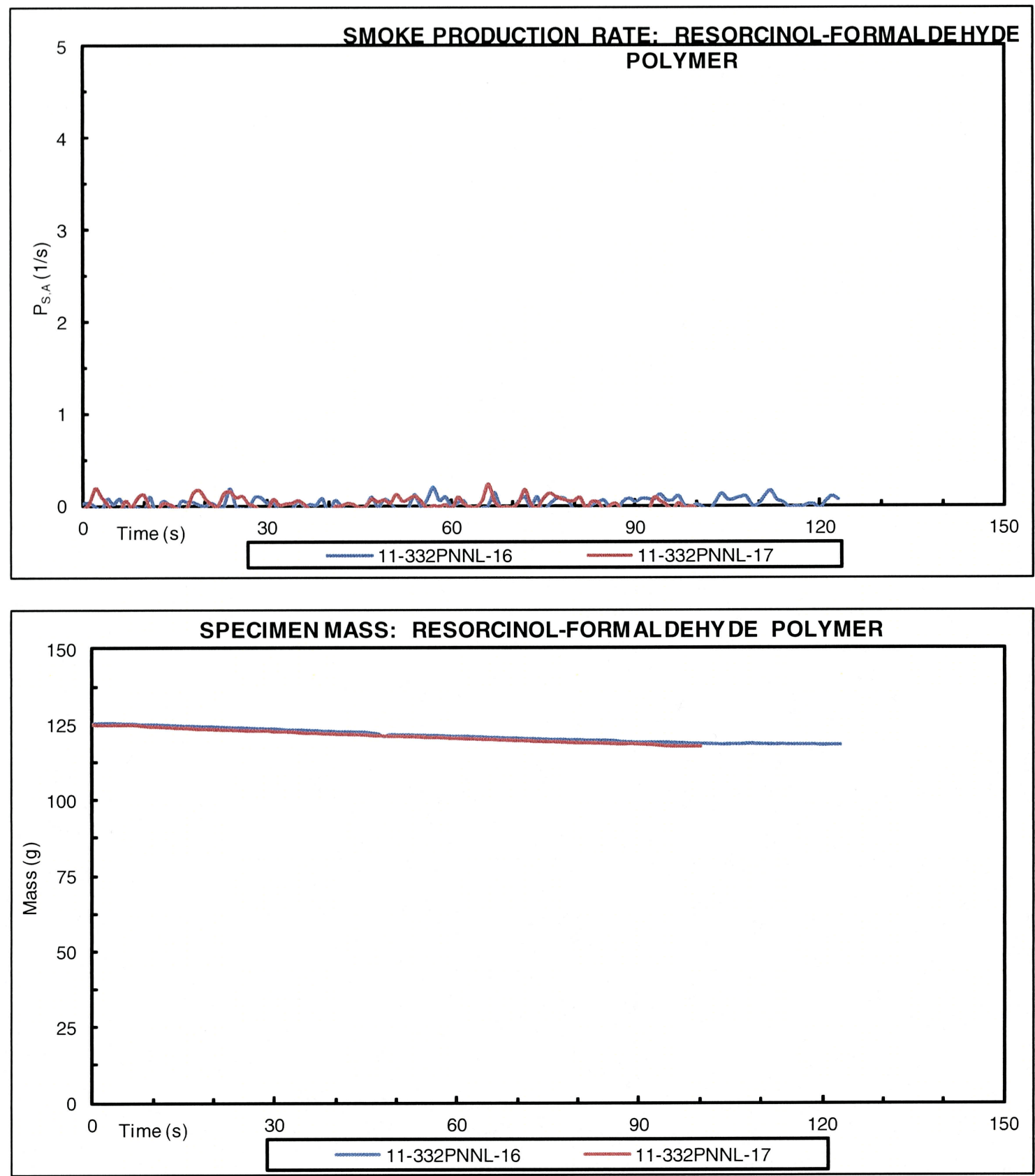

Notes \& Observations:

11-332PNNL-16 Regular Run

11-332PNNL-17 Duplicate Run 


\section{CONE CALORIMETER TEST REPORT}

\begin{tabular}{|c|c|c|c|c|c|c|c|c|c|c|}
\hline Client: & & Battel & le Memori & rial Institut & & Material & & $\begin{array}{l}\text { Resorcir } \\
\text { polymer }\end{array}$ & ol-Forma & dehyde \\
\hline SwRI Project No: & & 01.13 & 295.12 .00 & $08 \mathrm{c}$ & & Heat Fll & & $100 \mathrm{~kW} /$ & & \\
\hline & & & & & & Duct Flo & & $24 \mathrm{l} / \mathrm{s}$ & & \\
\hline Orientation: & & Horizc & ontal & & & Sample & Area: & 0.01000 & $m^{2}$ & \\
\hline Frame: & & No & & & & Distance & & $25 \mathrm{~mm}$ & & \\
\hline Spark Igniter: & & Yes & & & & Operato & & Alan $\mathrm{K}$. & _owry & \\
\hline Test ID & $\begin{array}{l}\text { Test } \\
\text { Date }\end{array}$ & $\begin{array}{l}\mathrm{t}_{\mathrm{ig}} \\
(\mathrm{s})\end{array}$ & $\begin{array}{c}\text { Test } \\
\text { Duration } \\
\text { (s) }\end{array}$ & $\begin{array}{l}\text { C-Factor } \\
\text { (SI Units) }\end{array}$ & $\begin{array}{l}\mathrm{HRR}_{\text {peak }} \\
\left(\mathrm{kW} / \mathrm{m}^{2}\right)\end{array}$ & $\begin{array}{c}\text { THR } \\
\left(\mathrm{MN} / \mathrm{m}^{2}\right)\end{array}$ & $\begin{array}{l}\mathrm{HRR}_{60 \mathrm{~s}} \\
\left(\mathrm{~kW} / \mathrm{m}^{2}\right)\end{array}$ & $\begin{array}{l}\mathrm{HRR}_{180 \mathrm{~s}} \\
\left(\mathrm{~kW} / \mathrm{m}^{2}\right)\end{array}$ & $\begin{array}{l}\mathrm{HRR}_{300 \mathrm{~s}} \\
\left(\mathrm{~kW} / \mathrm{m}^{2}\right)\end{array}$ & $\begin{array}{c}\mathrm{HRR}_{30 \mathrm{~s}, \max } \\
\left(\mathrm{kW} / \mathrm{m}^{2}\right)\end{array}$ \\
\hline 11-332PNNL-18 & $11 / 28 / 11$ & 40 & 58 & 0.0432 & 58 & 1.0 & & & & 44 \\
\hline 11-332PNNL-19 & $11 / 28 / 11$ & 38 & 58 & 0.0432 & 55 & 0.9 & & & & 39 \\
\hline Average & & 39 & 58 & -- & 56 & 0.9 & \#DIV/0! & \#DIV/0! & \#DIV/0! & 42 \\
\hline Initial Mass & $\begin{array}{l}\text { Mass at } \\
\text { Ignition }\end{array}$ & $\begin{array}{l}\text { Final } \\
\text { Mass }\end{array}$ & $\begin{array}{l}\text { Mass } \\
\text { Loss }\end{array}$ & MLR & $\begin{array}{c}10-90 \\
\text { MLR }\end{array}$ & $\mathrm{EHC}$ & $\mathrm{S}_{\mathrm{A}, 1}$ & $\mathrm{~S}_{\mathrm{A}, 2}$ & $\mathrm{~S}_{\mathrm{A}}$ & SEA \\
\hline & & (g) & $\left(\mathrm{g} / \mathrm{m}^{2}\right)$ & $\left(\mathrm{g} / \mathrm{m}^{2}-\mathrm{s}\right)$ & $\left(\mathrm{g} / \mathrm{m}^{2}-\mathrm{s}\right)$ & & & & & $\left(m^{2} / k g\right)$ \\
\hline 129.3 & 125.4 & 123.7 & 559 & 8.7 & 10.4 & 1.8 & 2 & 0 & 2 & 1 \\
\hline 130.8 & 127.0 & 125.0 & 579 & 9.8 & 10.3 & 1.5 & 1 & 1 & 1 & 1 \\
\hline 130.1 & 126.2 & 124.4 & 569 & 9.3 & 10.3 & 1.7 & 1 & 0 & 2 & 1 \\
\hline
\end{tabular}

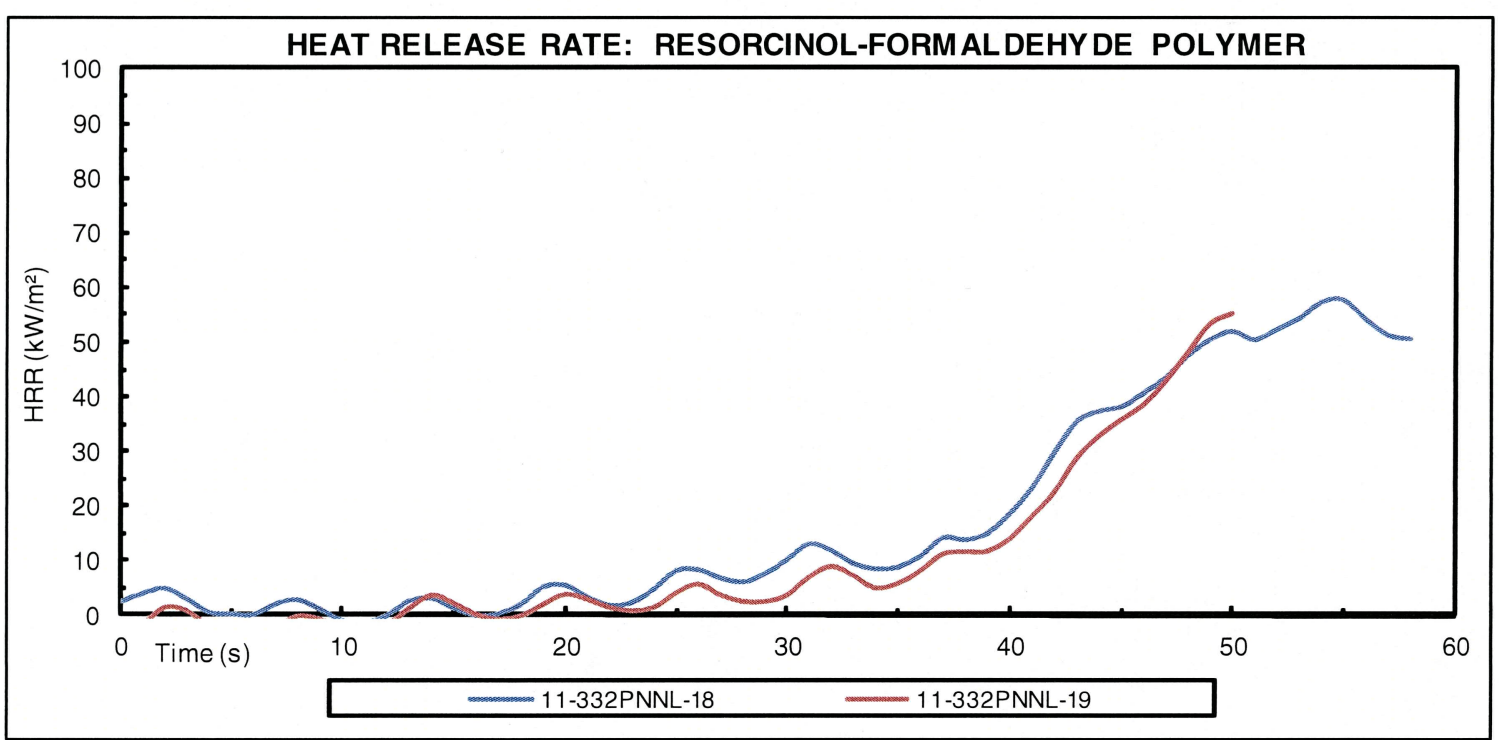




\section{CONE CALORIMETER TEST REPORT}

Material ID:

Client:

Battelle Memorial Institute

SwRI Project No: 01.13295.12.008c

Resorcinol-Formaldehyde polymer

Heat Flux: $\quad 100 \mathrm{~kW} / \mathrm{m}^{2}$

(Page 2)
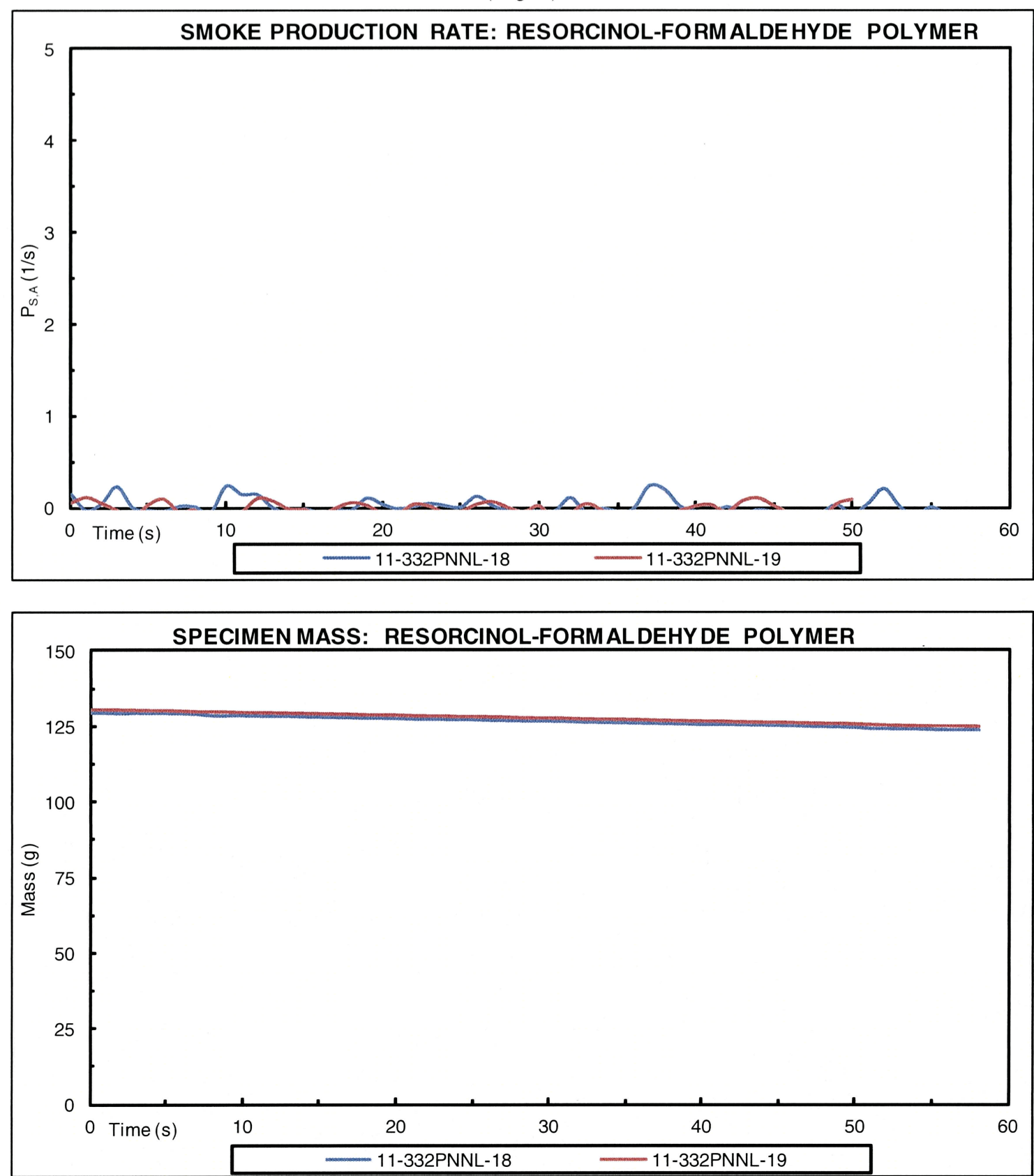

Notes \& Observations:

11-332PNNL-18 Regular Run

11-332PNNL-19 Duplicate Run 


\begin{tabular}{|c|c|c|c|c|c|c|c|}
\hline Material & $\begin{array}{c}\text { CHF } \\
\left(\mathrm{kW} / \mathrm{m}^{2}\right) \\
\text { Bracket }\end{array}$ & $\begin{array}{c}\text { CHF } \\
\left(\mathrm{kW} / \mathrm{m}^{2}\right) \\
\text { Extrap. }\end{array}$ & $\begin{array}{c}\text { TRP } \\
\left(\mathrm{kW}-\mathrm{s}^{1 / 2} / \mathrm{m}^{2}\right)\end{array}$ & $\begin{array}{c}\mathrm{HRR}_{p \equiv \Xi k} \\
\left(\mathrm{~kW} / \mathrm{m}^{2}\right) \\
\left(\text { @ } 50 \mathrm{~kW} / \mathrm{m}^{2}\right)\end{array}$ & $\begin{array}{c}\mathrm{HRR}_{\mathrm{p}=\mathrm{s}} \\
\left(\mathrm{kW} / \mathrm{m}^{2}\right) \\
\left(@ 100 \mathrm{~kW} / \mathrm{m}^{2}\right)\end{array}$ & $\begin{array}{l}\text { FPI, } 50 \mathrm{~kW} / \mathrm{m}^{2} \\
\left(\mathrm{~m}^{\mathrm{s} / 3} / \mathrm{kW}^{2 / 3}-\mathrm{s}^{1 / 2}\right)\end{array}$ & $\begin{array}{l}\text { FPI, } 100 \mathrm{~kW} / \mathrm{m}^{2} \\
\left(\mathrm{~m}^{5 / 3} / \mathrm{kW}^{2 / 3}-\mathrm{s}^{1 / 2}\right)\end{array}$ \\
\hline RFP & 420 & 40.3 & 465 & 44 & 51 & 264 & 2.77 \\
\hline
\end{tabular}

\begin{tabular}{|ccc|}
\hline \multicolumn{3}{|c|}{ Resorcinol-Formaldehyde Polymer (RFP) } \\
\hline Heat Flux & $\mathrm{t}_{\mathrm{g}}$ & $\mathrm{t}_{\mathrm{g}}{ }^{-1 / 2}$ \\
\hline 40 & 682 & 0.0383 \\
40 & 861 & 0.0341 \\
42 & 938 & 0.0327 \\
42 & 1075 & 0.0305 \\
50 & 215 & 0.0682 \\
50 & 263 & 0.0617 \\
50 & 274 & 0.0604 \\
50 & 109 & 0.0958 \\
60 & 132 & 0.0870 \\
60 & 123 & 0.090166963 \\
80 & 66 & 0.123091491 \\
80 & 60 & 0.129099445 \\
100 & 39 & 0.160128154 \\
100 & 48 & 0.144337567 \\
100 & 40 & 0.158113883 \\
100 & 33 & 0.174077656 \\
100 & 26 & 0.196116135 \\
100 & 26 & 0.196116135 \\
100 & 40 & 0.158113883 \\
100 & 38 & 0.162221421 \\
\hline
\end{tabular}

\begin{tabular}{|c|cc|}
\hline Material ID & $\begin{array}{c}\mathrm{T}_{\mathrm{ig}} \\
(\mathrm{K})\end{array}$ & $\begin{array}{c}\text { CHF } \\
\left(\mathrm{kW} / \mathrm{m}^{2}\right)\end{array}$ \\
\hline RFP-40 & 733 & 21.8 \\
RFP-40 & 811 & 31.0 \\
RFP-42 & 862 & 38.5 \\
RFP-42 & 949 & 54.4 \\
RFP-50 & 705 & 19.1 \\
RFP-50 & 832 & 33.9 \\
RFP-50 & 884 & 42.1 \\
RFP-50 & 430.05 & 3.3 \\
RFP-60 & 364.95 & 1.5 \\
RFP-60 & 613.95 & 11.9 \\
RFP_80 & 488.85 & 5.4 \\
RFP-80 & 447.65 & 3.9 \\
RFP-100 & 646.65 & 14.2 \\
RFP-100 & 364.35 & 1.5 \\
\hline \hline RFP-Average & 873 & 40.3 \\
\hline
\end{tabular}

\begin{tabular}{|c|}
\hline Peak Temp $\left({ }^{\circ} \mathbf{C}\right)$ \\
\hline 660.1 \\
\hline 612.4 \\
\hline 655.2 \\
\hline 664.1 \\
\hline
\end{tabular}


SOUTHWEST RESEARCH INSTITUTE CLIENT: Battelle Memorial Ins. PNNL TASK ORDER\#:

SRR\#:

SDG\#:

VTSR:

111111-12

46069

479235

PROJECT \#:

$11 / 11 / 2011$

13295.12.00X

\section{R13295.12.008b (ASTM E 1354 Testing)}




\section{S O U T H W E S T R E S E A R C H I N S T I T U T E ${ }^{\circledR}$}

FIRE PERFORMANCE EVALUATION IN GENERAL ACCORDANCE WITH ASTM E 1354-10, STANDARD TEST METHOD FOR HEAT AND VISIBLE SMOKE RELEASE RATES FOR MATERIALS AND PRODUCTS USING AN OXYGEN CONSUMPTION CALORIMETER

MATERIAL ID: RESORCINOL-FORMALDEHYDE POLYMER

FINAL REPORT

Consisting of 13 Pages

SwRI ${ }^{\circledR}$ Project No. 01.13295.12.008b

Test Dates: November 17, 21, and 22, 2011

Report Date: December 15, 2011

\section{Prepared for:}

\section{Battelle Memorial Institute}

902 Battelle Blvd, K6-79

P.O. Box 999

Richland, WA 99352

Submitted by:
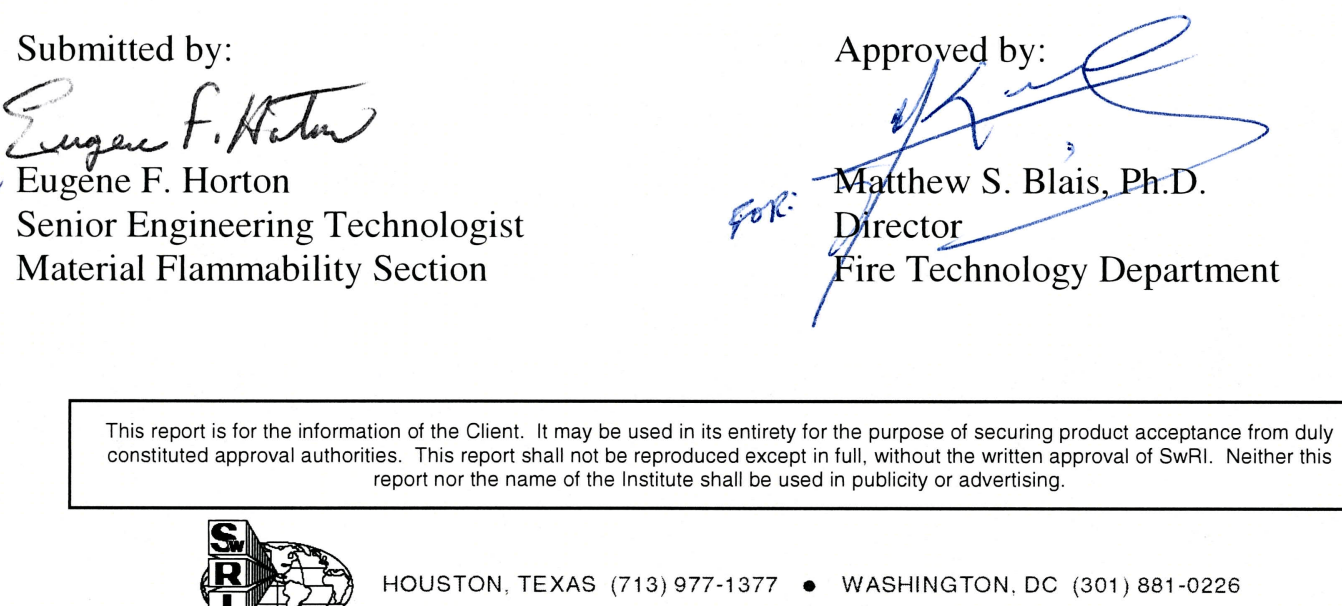

This report is for the information of the Client. It may be used in its entirety for the purpose of securing product acceptance from duly constituted approval authorities. This report shall not be reproduced except in full, without the written approval of SwRI. Neither this report nor the name of the Institute shall be used in publicity or advertising. 


\subsection{INTRODUCTION}

The objective of this test program was to conduct a fire performance evaluation on a material identified as Resorcinol-Formaldehyde Polymer, for Battelle Memorial Institute, located in Richland, Washington. The material was tested in general accordance with ASTM E 1354-10, Standard Test Method for Heat and Visible Smoke Release Rates for Materials and Products Using an Oxygen Consumption Calorimeter. Testing was performed on the test samples in accordance with the quality assurance requirements of the DOE/RL-96-68, Hanford Analytical Services Quality Assurance Requirements Documents, Volumes 1 and 4 (HASQARDS), latest revision. In accordance with the HASQARDs, a positive, a negative, and a duplicate test (consisting of three runs) were run in addition to the one standard test (consisting of three runs). Testing was conducted at a heat flux of $50 \mathrm{~kW} / \mathrm{m}^{2}$ on the positive and negative standards and $100 \mathrm{~kW} / \mathrm{m}^{2}$ on the Resorcinol-Formaldehyde Polymer. Testing was conducted on November 17, 21, and 22, 2011, at Southwest Research Institute's (SwRI) Fire Technology Department, in San Antonio, Texas.

The negative tests were performed on marinate board; measuring $100 \times 100 \times 18 \mathrm{~mm}$ which is a non-combustible material. This material is often used as a substrate or backer board in standard fire testing. It does not react to flame or heat except to lose moisture. The positive tests were performed on PMMA (Poly methyl methacrylate) measuring approximately $100 \times 100 \times 10 \mathrm{~mm}$. This is a know standard used in testing and it was selected as the positive standard.

This test method is intended to measure and describe the properties of materials or products in response to heat and flame under controlled laboratory conditions. This method is not applicable to end-use products that do not have planar, or nearly planar, external surfaces. The results should not be used alone to describe or appraise the fire hazard or the fire risk of materials, products, or assemblies under actual fire conditions. However, results of this test may be used as elements of a complete fire hazard assessment or a fire risk assessment, which takes into account all the factors that are pertinent to an assessment of the fire hazard or fire risk of a particular end use. The results apply specifically to the specimens tested, in the manner tested, and not to similar materials, nor to the performance when used in combination with other materials.

\subsection{CONE CALORIMETER}

For organic solids, liquids, and gases, a nearly constant net amount of heat is released per unit mass of oxygen consumed for complete combustion. An average value for this constant of 13.1 MJ/kg of $\mathrm{O}_{2}$ can be used for practical applications and is accurate with very few exceptions to within $\pm 5 \%$. Therefore, measurements of the oxygen consumed in a combustion system can be used to determine the net heat released. This technique, generally referred to as the "oxygen consumption technique", is now the most widely used and accurate method for measuring heat release rate in experimental fires. 
The Cone Calorimeter is a sophisticated small-scale test apparatus, which measures the rate of heat release of materials and products under a wide range of conditions using the oxygen consumption technique. A schematic of the instrument is shown in Figure 1. Other useful information obtained from Cone Calorimeter tests includes time to ignition, mass loss rate, smoke production rate, and effective heat of combustion.

In the Cone Calorimeter, a square sample measuring $100 \times 100 \mathrm{~mm}(4 \times 4 \mathrm{in}$. $)$ is exposed to the radiant flux of an electric heater. The heater is in the shape of a truncated cone and is capable of providing heat fluxes to the specimen in the range of $0-100 \mathrm{~kW} / \mathrm{m}^{2}$. An electric spark igniter is used for piloted ignition of the pyrolysis gases produced by the radiant heater.

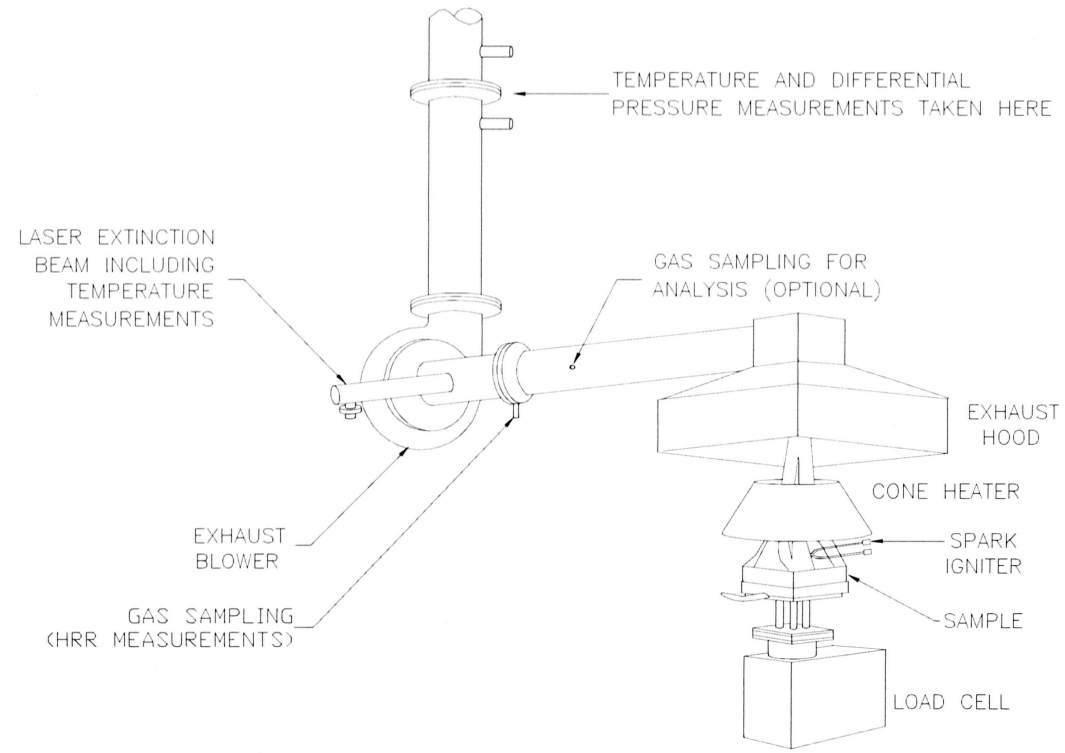

Figure 1. Schematic of the Cone Calorimeter Apparatus.

Test specimens are to be representative of the product's end use and can have a maximum thickness of $50 \mathrm{~mm}$ ( 2 in.). Specimens with a thickness of less than $6 \mathrm{~mm}$ are to be tested using a substrate that is representative of end-use conditions. Prior to testing, the test specimen is wrapped in aluminum foil, backed with a layer of low-density refractory fiber blanket, and placed in a standard specimen holder. An optional edge frame can be used to retain the sample within the specimen holder during testing. A load cell is used to measure the mass loss of the specimen throughout the duration of the test.

At the start of a test, the specimen (in the appropriate holder) is placed on the load cell, which is located below the heater. The top edge of the specimen is typically positioned $25 \mathrm{~mm}$ below the base plate of the heater. The electric spark igniter is located $13 \mathrm{~mm}$ above the center of the specimen. Four seconds after the pyrolysis gases released by the specimen ignite; the electric spark igniter is removed.

The products of combustion and entrained air are collected in a hood and extracted through an exhaust duct by a fan. A gas sample is drawn from the exhaust duct and analyzed for oxygen 
concentration. The gas temperature and differential pressure across an orifice plate are used for calculating the mass flow rate of the exhaust gases. Smoke production is determined based on the measured light obscuration in the duct using a laser photometer located close to the gas sampling point.

The Cone Calorimeter apparatus, calibration procedure, and test protocol are standardized in the United States as ASTM E 1354-10 and NFPA 271:2009, Standard Test Method for Heat and Visible Smoke Release Rates for Materials and Products Using an Oxygen Consumption Calorimeter and internationally as ISO 5660-1:2002, Fire tests-Reaction to fire-Part 1: Rate of heat release from building products-(Cone calorimeter method). ASTM E 1354 and NFPA 271 are functionally identical. SwRI's Cone Calorimeter is capable of performing tests in accordance with the ASTM, NFPA, and ISO standards.

Although the test procedure is prescribed in the ASTM, NFPA, and ISO standards, the standards do not specify operating parameters such as heat flux, specimen orientation, use of retainer frame and grid, etc. The choice of a suitable set of parameters is a function of the type and application of the product being tested. These parameters are usually specified by the Client, and are described in Section 4.0 of this report.

\subsection{DESCRIPTION OF TEST SPECIMENS}

Battelle Memorial Institute, provided a material identified as Resorcinol-Formaldehyde Polymer for testing in accordance with ASTM E 1354-10. See Table 1 for the test sample description provided by the Client. SwRI received one 20 liter bottle of specimen described in the table below on November 11, 2011.

Table 1. Test Sample Identification Description as Provided by Battelle Memorial Institute.

\begin{tabular}{|c|c|c|}
\hline Material ID & Description & Color \\
\hline $\begin{array}{c}\text { Resorcinol- } \\
\text { Formaldehyde } \\
\text { Polymer }\end{array}$ & Micro Beads & Red \\
\hline
\end{tabular}

* Measured by SwRI personnel.

Specimen preparation was in accordance with ASTM E 1354-10. The samples provided consisted of a micro bead material dispersed in water. The material was tested in worst case scenario, which is with the water removed. This process was achieved by first filtering the material, and then drying it in an oven. The sample was dried for a minimum of $10 \mathrm{~h}$ at $60{ }^{\circ} \mathrm{C} \pm 3{ }^{\circ} \mathrm{C}\left(140{ }^{\circ} \mathrm{F} \pm 5{ }^{\circ} \mathrm{F}\right)$ prior to testing. After drying, the sample consisted of only the micro bead material; the beads became statically charged in the absence of the water medium and therefore, they were placed in a closed container after drying, in an effort not to lose any beads. Each sample was then conditioned in a controlled environment maintained at $23{ }^{\circ} \mathrm{C} \pm 3{ }^{\circ} \mathrm{C}$ and $50 \% \pm 5 \%$ relative humidity until just prior to testing. 


\subsection{TEST PROCEDURE}

Two triplicate tests were performed in general accordance with ASTM E 1354-10 at a heat flux of $100 \mathrm{~kW} / \mathrm{m}^{2}$. Single runs were conducted on PMMA \& Marinite standards at a heat flux of $50 \mathrm{~kW} / \mathrm{m}^{2}$. Tests were conducted in the horizontal orientation. The data collection sampling interval was set at $1 \mathrm{~s}$. Tests were concluded 2 min after flameout.

\subsection{TEST RESULTS}

Testing was conducted at SwRI's Fire Technology Department located in San Antonio, Texas, on November 17, 21, and 22, 2011. Cone Calorimeter test results are summarized in tabular and graphical form in the standard SwRI ASTM E 1354 Cone Calorimeter data sheets provided in Appendix A. Heat release, mass loss, and smoke production data (SPR, SR 1 , and TSR) are calculated. The following terms and abbreviations are used:

- $\mathrm{t}_{\mathrm{ig}}$

- Test Duration

- C-Factor

- HRR $_{\text {peak }}$

- THR

- $\mathrm{HRR}_{60 \mathrm{~s}}$

- $\mathrm{HRR}_{180 \mathrm{~s}}$

- $\mathrm{HRR}_{300 \mathrm{~s}}$

- $\quad \mathrm{HRR}_{30 \mathrm{~s}, \max }$

- Initial Mass time to ignition/sustained flaming (flame over specimen surface for at least $4 \mathrm{~s}$ )

total test duration (time from the start of test until any flaming or other signs of combustion cease, the average mass loss over a 1-min period has dropped below $150 \mathrm{~g} / \mathrm{m}^{2}$, or until $60 \mathrm{~min}$ have elapsed)

calibration constant for oxygen consumption analysis $\left(\mathrm{m}^{1 / 2}-\mathrm{kg}^{1 / 2}-K^{1 / 2}\right)$

maximum value of the heat release rate per unit area $\left(\mathrm{kW} / \mathrm{m}^{2}\right)$

total amount of heat released per square meter $\left(\mathrm{MJ} / \mathrm{m}^{2}\right)$

average heat release rate over the first $60 \mathrm{~s}(1 \mathrm{~min})$ after ignition

average heat release rate over the first $180 \mathrm{~s}(3 \mathrm{~min})$ after ignition

average heat release rate over the first $300 \mathrm{~s}$ ( $5 \mathrm{~min}$ ) after ignition

the maximum 30-s sliding average of the heat release rate per unit area $\left(\mathrm{kW} / \mathrm{m}^{2}\right)$

the initial mass of the test specimen, prior to testing $(\mathrm{g})$

- Mass at Ignition the mass of the test specimen at the time of sustained ignition $(\mathrm{g})$

- Final Mass the mass of the test specimen at the end of the test $(\mathrm{g})$

- Mass Loss

- MLR

- $\quad$ 10-90 MLR total specimen mass loss over the test $\left(\mathrm{g} / \mathrm{m}^{2}\right)$

average specimen mass loss rate per unit area $\left(\mathrm{g} / \mathrm{m}^{2} \cdot \mathrm{s}\right)$ computed over the test duration

average specimen mass loss rate per unit area $\left(\mathrm{g} / \mathrm{m}^{2} \cdot \mathrm{s}\right)$ computed over the period starting when $10 \%$ of the specimen mass loss occurred and ending when $90 \%$ of the specimen mass loss occurred

- $\mathrm{EHC}$

- $\mathrm{S}_{\mathrm{A}, 1}$

- $\mathrm{S}_{\mathrm{A} .2}$

- $\mathrm{S}_{\mathrm{A}}$ effective heat of combustion (the ratio of heat release rate to mass loss rate$\mathrm{MJ} / \mathrm{kg}$ ) averaged over the test duration or the entire test if ignition does not occur smoke production per unit area of exposed specimen $\left(\mathrm{m}^{2} / \mathrm{m}^{2}\right)$ prior to ignition smoke production per unit area of exposed specimen $\left(\mathrm{m}^{2} / \mathrm{m}^{2}\right)$ from ignition until flameout or the end of the test; equal to zero if ignition does not occur

total smoke production per unit area of exposed specimen during the test duration $\left(\mathrm{S}_{\mathrm{A}, 1}+\mathrm{S}_{\mathrm{A}, 2}\right)$ 
- SEA

specific smoke extinction area (the ratio of smoke production to specimen mass loss $-\mathrm{m}^{2} / \mathrm{kg}$ ) averaged

over

the

test duration. 
APPENDIX A

CONE CALORIMETER DATA

(Consisting of 6 Pages) 


\section{CONE CALORIMETER TEST REPORT}

$\begin{array}{llll}\text { Client: } & \text { Battelle Memorial Institute } & \text { Material ID: } & \text { See Notes } \\ \text { SwRI Project No: } & \text { 01.13295.12.008b } & \text { Heat Flux: } & 50 \mathrm{~kW} / \mathrm{m}^{2} \\ & & \text { Duct Flow: } & 24 \mathrm{l} / \mathrm{s} \\ \text { Orientation: } & \text { Horizontal } & \text { Sample Area: } & 0.00884 \mathrm{~m}^{2} \\ \text { Frame: } & \text { Yes } & \text { Distance: } & 25 \mathrm{~mm} \\ \text { Spark Igniter: } & \text { Yes } & \text { Operator: } & \text { Alan K. Lowry }\end{array}$

\begin{tabular}{|c|c|c|c|c|c|c|c|c|c|c|}
\hline Test ID & $\begin{array}{l}\text { Test } \\
\text { Date }\end{array}$ & $\begin{array}{l}t_{i g} \\
\text { (s) }\end{array}$ & $\begin{array}{c}\text { Test } \\
\text { Duration } \\
\text { (s) }\end{array}$ & $\begin{array}{l}\text { C-Factor } \\
\text { (SI Units) }\end{array}$ & $\begin{array}{l}\mathrm{HRR}_{\text {peak }} \\
\left(\mathrm{kW} / \mathrm{m}^{2}\right)\end{array}$ & $\begin{array}{c}\text { THR } \\
\left(\mathrm{MJ} / \mathrm{m}^{2}\right)\end{array}$ & $\begin{array}{l}\mathrm{HRR}_{60 \mathrm{~s}} \\
\left(\mathrm{~kW} / \mathrm{m}^{2}\right)\end{array}$ & $\begin{array}{l}\mathrm{HRR}_{180 \mathrm{~s}} \\
\left(\mathrm{~kW} / \mathrm{m}^{2}\right)\end{array}$ & $\begin{array}{l}\mathrm{HRR}_{300 \mathrm{~s}} \\
\left(\mathrm{~kW} / \mathrm{m}^{2}\right)\end{array}$ & $\begin{array}{c}\mathrm{HRR}_{30 \mathrm{~s}, \max } \\
\left(\mathrm{kW} / \mathrm{m}^{2}\right)\end{array}$ \\
\hline 11-321BAT-1 & $11 / 17 / 11$ & $\mathrm{NI}$ & 1800 & 0.0437 & 5 & 0.2 & -1 & -1 & -1 & 0 \\
\hline 11-321BAT-2 & $11 / 17 / 11$ & 23 & 623 & 0.0437 & 819 & 414.1 & 455 & 587 & 631 & 771 \\
\hline \multicolumn{2}{|c|}{ Average } & 23 & 1212 & --- & 412 & 207.1 & 227 & 293 & 315 & 386 \\
\hline \multicolumn{11}{|l|}{$N I=$ No Ignition } \\
\hline $\begin{array}{c}\text { Initial Mass } \\
\text { (g) }\end{array}$ & $\begin{array}{l}\text { Mass at } \\
\text { Ignition } \\
\text { (g) }\end{array}$ & $\begin{array}{c}\text { Final } \\
\text { Mass } \\
(\mathrm{g})\end{array}$ & $\begin{array}{l}\text { Mass } \\
\text { Loss } \\
\left(\mathrm{g} / \mathrm{m}^{2}\right)\end{array}$ & $\begin{array}{c}\text { MLR } \\
\left(\mathrm{g} / \mathrm{m}^{2}-\mathrm{s}\right)\end{array}$ & $\begin{array}{c}10-90 \\
\text { MLR } \\
\left(\mathrm{g} / \mathrm{m}^{2}-\mathrm{s}\right)\end{array}$ & $\begin{array}{c}\mathrm{EHC} \\
(\mathrm{MJ} / \mathrm{kg})\end{array}$ & $\begin{array}{c}\mathrm{S}_{\mathrm{A}, 1} \\
\left(\mathrm{~m}^{2} / \mathrm{m}^{2}\right)\end{array}$ & $\begin{array}{c}\mathrm{S}_{\mathrm{A}, 2} \\
\left(\mathrm{~m}^{2} / \mathrm{m}^{2}\right)\end{array}$ & $\begin{array}{c}\mathrm{S}_{\mathrm{A}} \\
\left(\mathrm{m}^{2} / \mathrm{m}^{2}\right)\end{array}$ & $\begin{array}{c}\text { SEA } \\
\left(\mathrm{m}^{2} / \mathrm{kg}\right)\end{array}$ \\
\hline 87.4 & $\mathrm{NI}$ & 83.3 & 465 & 0.2 & 0.3 & 0.3 & 42 & $\mathrm{~N} / \mathrm{A}$ & 42 & 91 \\
\hline 208.1 & 207.9 & 38.9 & 19139 & 30.7 & 32.9 & 21.6 & 1 & 1377 & 1377 & 72 \\
\hline 147.8 & 207.9 & 61.1 & 9802 & 15.5 & 16.6 & 11.0 & 22 & 1377 & 710 & 81 \\
\hline
\end{tabular}

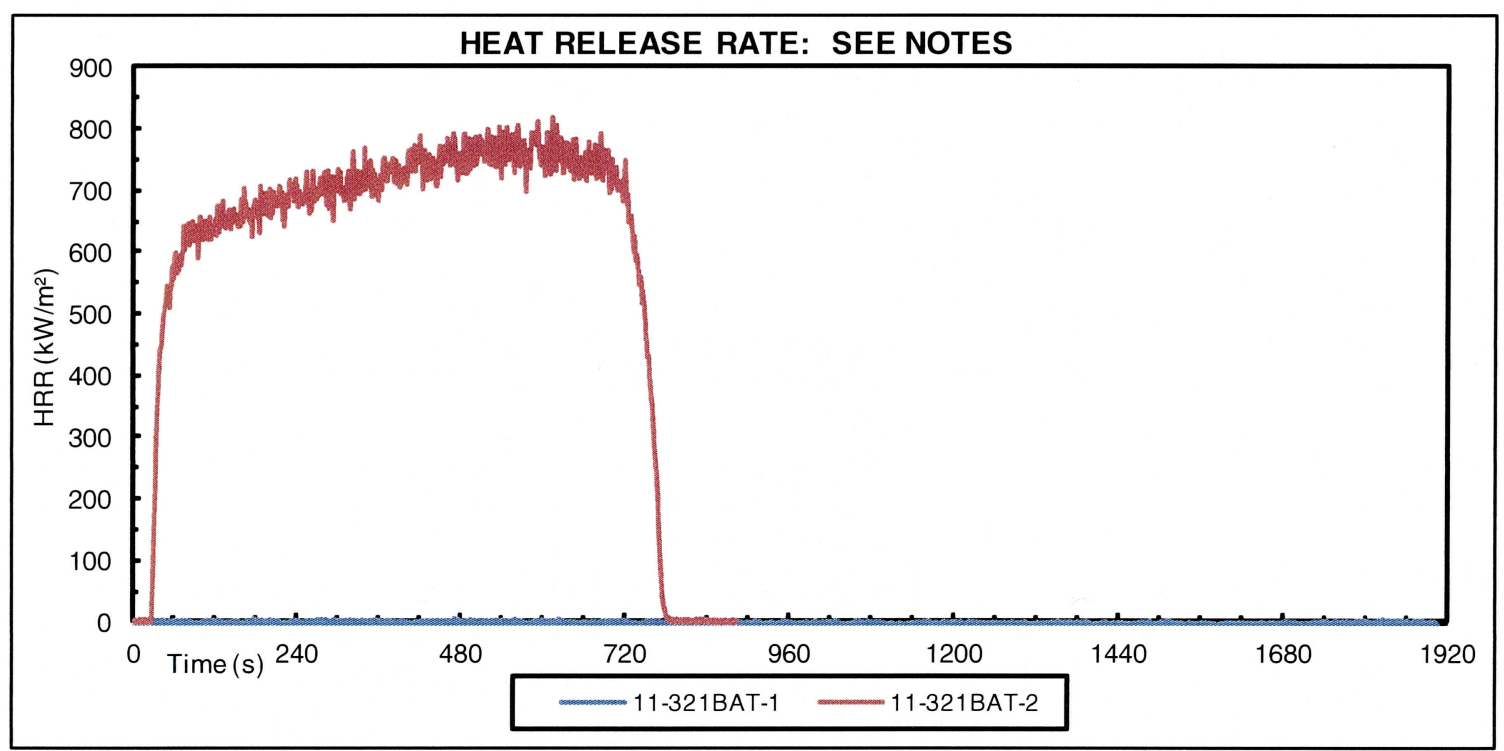




\section{CONE CALORIMETER TEST REPORT}

Client:

SwRI Project No: 01.13295.12.008b
Material ID:

Heat Flux:
See Notes

$50 \mathrm{~kW} / \mathrm{m}^{2}$

(Page 2)
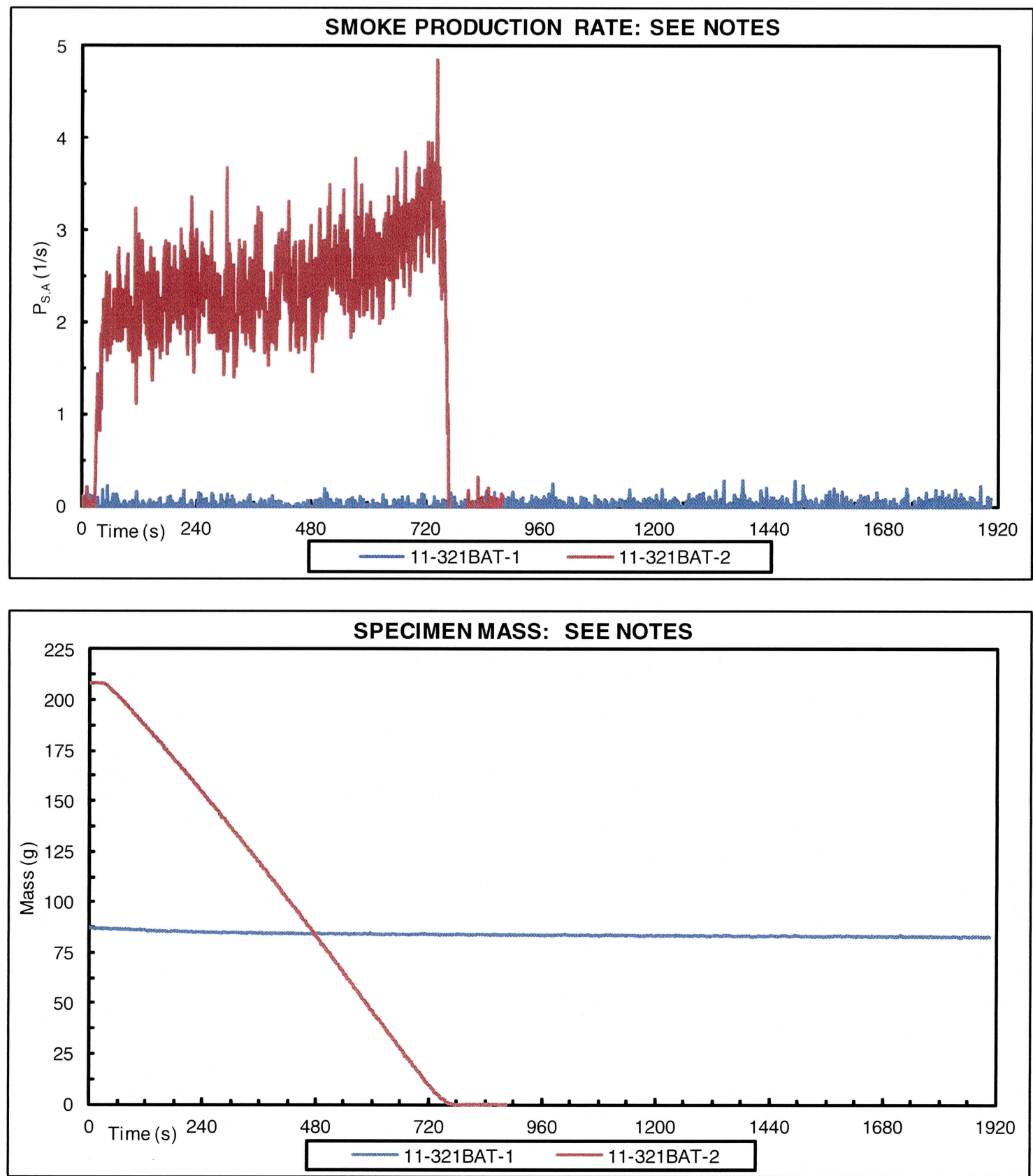

Notes \& Observations:

11-321BAT-1 Marinate Standard

11-321BAT-2 PMMA Standard 


\section{CONE CALORIMETER TEST REPORT}

$\begin{array}{llll}\text { Client: } & \text { Battelle Memorial Institute } & \text { Material ID: } & \begin{array}{l}\text { Resorcinol-Formaldehyde } \\ \text { polymer }\end{array} \\ \text { SwRI Project No: } & 01.13295 .12 .008 \mathrm{~b} & \text { Heat Flux: } & 100 \mathrm{~kW} / \mathrm{m}^{2} \\ & & \text { Duct Flow: } & 24 \mathrm{l} / \mathrm{s} \\ \text { Orientation: } & \text { Horizontal } & \text { Sample Area: } & 0.01000 \mathrm{~m}^{2} \\ \text { Frame: } & \text { No } & \text { Distance: } & 25 \mathrm{~mm} \\ \text { Spark Igniter: } & \text { Yes } & \text { Operator: } & \text { Alan K. Lowry }\end{array}$

\begin{tabular}{|c|c|c|c|c|c|c|c|c|c|c|}
\hline Test ID & Test Date & $\begin{array}{l}t_{i g} \\
\text { (s) }\end{array}$ & $\begin{array}{c}\text { Test } \\
\text { Duration } \\
\text { (s) }\end{array}$ & $\begin{array}{l}\text { C-Factor } \\
\text { (SI Units) }\end{array}$ & $\begin{array}{l}\mathrm{HRR}_{\text {peak }} \\
\left(\mathrm{kW} / \mathrm{m}^{2}\right)\end{array}$ & $\begin{array}{c}\text { THR } \\
\left(\mathrm{MN} / \mathrm{m}^{2}\right)\end{array}$ & $\begin{array}{l}\mathrm{HRR}_{60 \mathrm{~s}} \\
\left(\mathrm{~kW} / \mathrm{m}^{2}\right)\end{array}$ & $\begin{array}{l}\mathrm{HRR}_{180 \mathrm{~s}} \\
\left(\mathrm{~kW} / \mathrm{m}^{2}\right)\end{array}$ & $\begin{array}{l}\mathrm{HRR}_{300 \mathrm{~s}} \\
\left(\mathrm{~kW} / \mathrm{m}^{2}\right)\end{array}$ & $\begin{array}{c}\mathrm{HRR}_{30 \mathrm{~s}, \max } \\
\left(\mathrm{kW} / \mathrm{m}^{2}\right)\end{array}$ \\
\hline 11-325PNNL-1 & $11 / 21 / 11$ & 39 & 3600 & 0.0436 & 48 & 120.6 & 41 & 38 & 38 & 44 \\
\hline 11-325PNNL-2 & $11 / 21 / 11$ & 48 & 3600 & 0.0436 & 51 & 125.3 & 44 & 40 & 39 & 47 \\
\hline 11-325PNNL-3 & $11 / 21 / 11$ & 40 & 3600 & 0.0436 & 50 & 121.9 & 42 & 39 & 38 & 46 \\
\hline$A v$ & & 42 & 3600 & --- & 50 & 122.6 & 42 & 39 & 38 & 46 \\
\hline
\end{tabular}

\begin{tabular}{|ccccccccccc|}
\hline Initial Mass & $\begin{array}{c}\text { Mass at } \\
\text { Ignition } \\
(\mathrm{g})\end{array}$ & $\begin{array}{c}\text { Final } \\
\text { Mass } \\
(\mathrm{g})\end{array}$ & $\begin{array}{c}\text { Mass } \\
\text { Loss } \\
\left(\mathrm{g} / \mathrm{m}^{2}\right)\end{array}$ & $\begin{array}{c}\text { MLR } \\
\left(\mathrm{g} / \mathrm{m}^{2}-\mathrm{s}\right)\end{array}$ & $\begin{array}{c}10-90 \\
\mathrm{MLR}\end{array}$ & $\begin{array}{c}\left.\mathrm{E} / \mathrm{m}^{2}-\mathrm{s}\right) \\
(\mathrm{MJ} / \mathrm{kg})\end{array}$ & $\begin{array}{c}\mathrm{S}_{\mathrm{A}, 1} \\
\left(\mathrm{~m}^{2} / \mathrm{m}^{2}\right)\end{array}$ & $\begin{array}{c}\mathrm{S}_{\mathrm{A}, 2} \\
\left(\mathrm{~m}^{2} / \mathrm{m}^{2}\right)\end{array}$ & $\begin{array}{c}\mathrm{S}_{\mathrm{A}} \\
\left(\mathrm{m}^{2} / \mathrm{m}^{2}\right)\end{array}$ & $\begin{array}{c}\text { SEA } \\
\left(\mathrm{m}^{2} / \mathrm{kg}\right)\end{array}$ \\
\hline 125.2 & 121.6 & 27.6 & 9756 & 2.7 & 3.0 & 12.4 & 0 & 13 & 14 & 1 \\
128.8 & 123.9 & 30.2 & 9859 & 2.7 & 3.0 & 12.7 & 1 & 83 & 84 & 8 \\
128.7 & 124.6 & 30.5 & 9817 & 2.7 & 3.0 & 12.4 & 1 & 129 & 129 & 13 \\
& & & & & & & & & & \\
& & & & & & & & & & \\
\hline 127.6 & 123.4 & 29.5 & 9810 & 2.7 & 3.0 & 12.5 & 1 & 75 & 76 & 8 \\
\hline
\end{tabular}

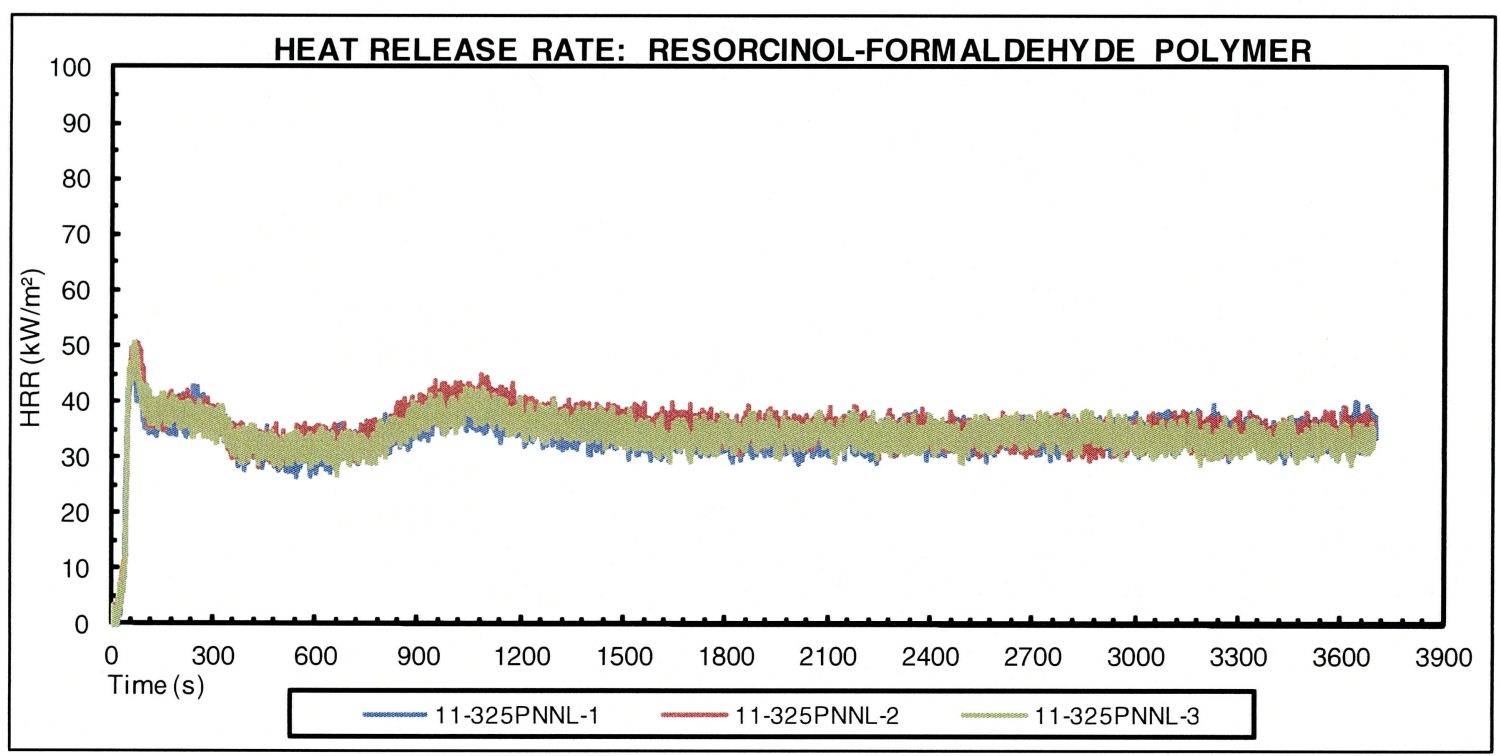




\section{CONE CALORIMETER TEST REPORT}

Client: $\quad$ Battelle Memorial Institute

SwRI Project No: 01.13295.12.008b
Material ID:

Heat Flux:
Resorcinol-Formaldehyde polymer

$100 \mathrm{~kW} / \mathrm{m}^{2}$

(Page 2)
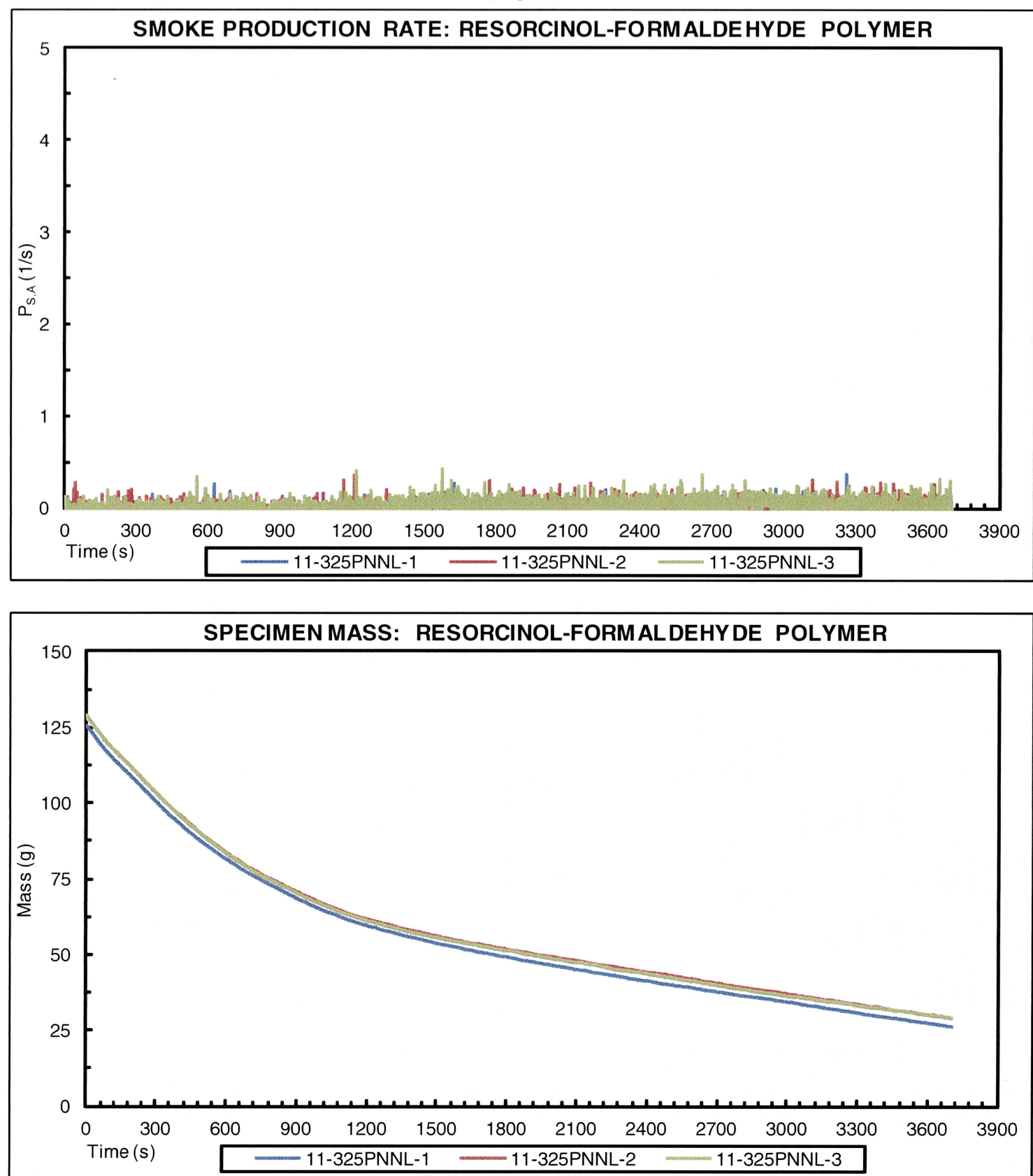

Notes \& Observations: 


\section{CONE CALORIMETER TEST REPORT}

\begin{tabular}{|c|c|c|c|c|c|c|c|c|c|c|}
\hline Client: & & Battel & le Memor & ial Institu & & Material & ID: & $\begin{array}{l}\text { Resorcir } \\
\text { polymer }\end{array}$ & ol-Forma & aldehyde \\
\hline SwRI Project $N$ & & 01.13 & 295.12 .00 & $8 b$ & & Heat Flc & & $100 \mathrm{~kW} /$ & $\mathrm{m}^{2}$ & \\
\hline & & & & & & Duct Flc & & $24 \mathrm{l} / \mathrm{s}$ & & \\
\hline Orientation: & & Horizc & ntal & & & Sample & Area: & 0.01000 & $\mathrm{~m}^{2}$ & \\
\hline Frame: & & No & & & & Distanc & & $25 \mathrm{~mm}$ & & \\
\hline Spark Igniter: & & Yes & & & & Operato & & Alan K. & Lowry & \\
\hline Test ID & Test Date & $\begin{array}{l}t_{i g} \\
(s)\end{array}$ & $\begin{array}{c}\text { Test } \\
\text { Duration } \\
\text { (s) }\end{array}$ & $\begin{array}{l}\text { C-Factor } \\
\text { (SI Units) }\end{array}$ & $\begin{array}{l}\mathrm{HRR}_{\text {peak }} \\
\left(\mathrm{kW} / \mathrm{m}^{2}\right)\end{array}$ & $\begin{array}{c}\text { THR } \\
\left(\mathrm{MN} / \mathrm{m}^{2}\right)\end{array}$ & $\begin{array}{l}\mathrm{HRR}_{60 \mathrm{~s}} \\
\left(\mathrm{~kW} / \mathrm{m}^{2}\right)\end{array}$ & $\begin{array}{l}\mathrm{HRR}_{180 \mathrm{~s}} \\
\left(\mathrm{~kW} / \mathrm{m}^{2}\right)\end{array}$ & $\begin{array}{l}\mathrm{HRR}_{300 \mathrm{~s}} \\
\left(\mathrm{~kW} / \mathrm{m}^{2}\right)\end{array}$ & $\begin{array}{c}\mathrm{HRR}_{30 \mathrm{~s}, \max } \\
\left(\mathrm{kW} / \mathrm{m}^{2}\right)\end{array}$ \\
\hline 11-325PNNL-4 & $11 / 21 / 11$ & 33 & 3600 & 0.0436 & 55 & 128.1 & 45 & 42 & 41 & 49 \\
\hline 11-326PNNL-5 & $11 / 22 / 11$ & 26 & 3600 & 0.0439 & 50 & 125.0 & 43 & 39 & 37 & 46 \\
\hline 11-326PNNL-6 & $11 / 22 / 11$ & 26 & 3600 & 0.0439 & 53 & 119.2 & 43 & 39 & 37 & 46 \\
\hline Averag & & 28 & 3600 & --- & 53 & 124.1 & 44 & 40 & 38 & 47 \\
\hline Initial Mass & $\begin{array}{l}\text { Mass at } \\
\text { Ignition }\end{array}$ & $\begin{array}{l}\text { Final } \\
\text { Mass }\end{array}$ & $\begin{array}{l}\text { Mass } \\
\text { Loss }\end{array}$ & MLR & $\begin{array}{c}10-90 \\
\text { MLR }\end{array}$ & $\mathrm{EHC}$ & $\mathrm{S}_{\mathrm{A}, 1}$ & $\mathrm{~S}_{\mathrm{A}, 2}$ & $\mathrm{~S}_{\mathrm{A}}$ & SEA \\
\hline (g) & (g) & (g) & $\left(\mathrm{g} / \mathrm{m}^{2}\right)$ & $\left(\mathrm{g} / \mathrm{m}^{2}-\mathrm{s}\right)$ & $\left(\mathrm{g} / \mathrm{m}^{2}-\mathrm{s}\right)$ & (Mv/kg) & $\left(m^{2} / m^{2}\right)$ & $\left(m^{2} / m^{2}\right)$ & $\left(m^{2} / m^{2}\right)$ & $\left(\mathrm{m}^{2} / \mathrm{kg}\right)$ \\
\hline 124.1 & 121.1 & 32.2 & 9186 & 2.6 & 2.8 & 13.9 & 2 & 197 & 199 & 21 \\
\hline 119.8 & 117.4 & 31.3 & 8847 & 2.5 & 2.6 & 14.1 & 1 & 244 & 245 & 28 \\
\hline 119.7 & 117.9 & 36.6 & 8315 & 2.3 & 2.4 & 14.3 & 0 & 34 & 34 & 4 \\
\hline 121.2 & 118.8 & 33.4 & 8782 & 2.5 & 2.6 & 14.1 & 1 & 158 & 159 & 18 \\
\hline
\end{tabular}

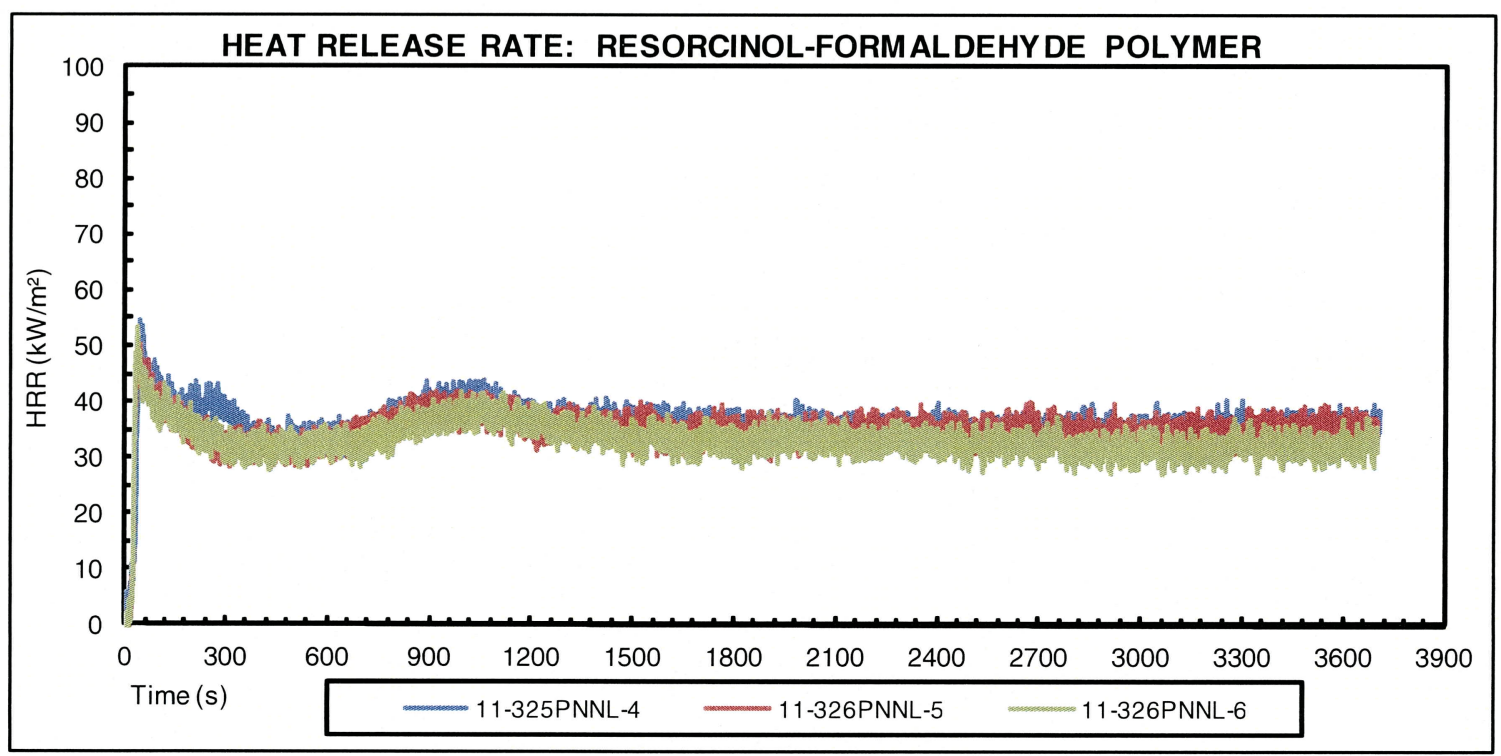




\section{CONE CALORIMETER TEST REPORT}

$\begin{array}{llll} & \text { Battelle Memorial Institute } & \text { Material ID: } & \text { Resorcinol-Formaldehyde } \\ \text { Client: } & & \text { polymer } \\ \text { SwRI Project No: } 01.13295 .12 .008 \mathrm{~b} & \text { Heat Flux: } & 100 \mathrm{~kW} / \mathrm{m}^{2} \\ & \text { (Page 2) } & \end{array}$
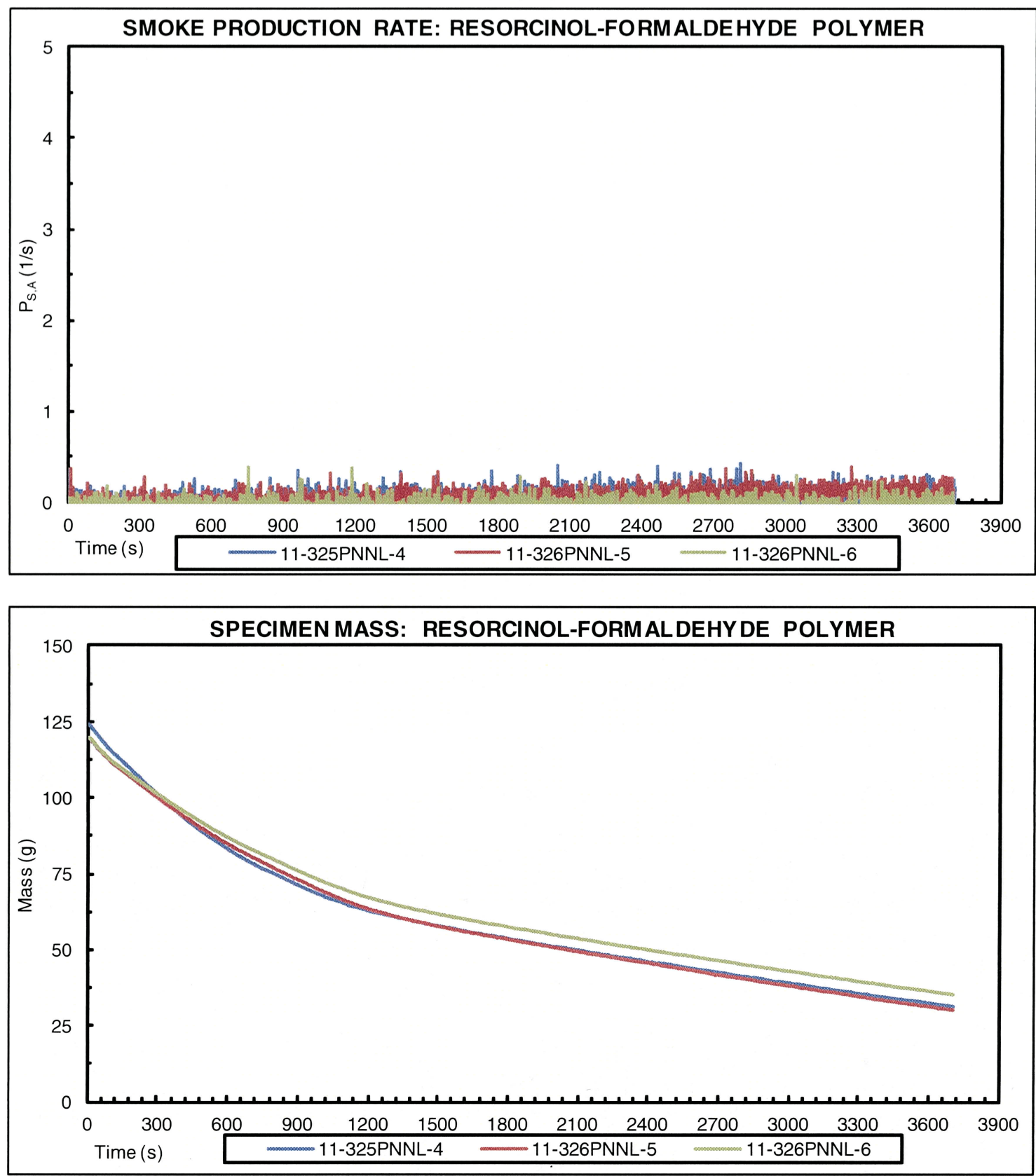

Notes \& Observations: $\quad$ This triplicate run is a duplicate test as per HASQARD requirements. 
SOUTHWEST RESEARCH INSTITUTE CLIENT: Battelle Memorial Ins. PNNL TASK ORDER\#:

SRR\#:

SDG\#:

VTSR:

111111-12

46069

479235

PROJECT \#:

$11 / 11 / 2011$

13295.12.00X

\section{R13295.12.008d (ASTM D 7309 Testing)}




\section{S O U T H W E S T R E S E A R C H I N S T I T U T E}

6220 CULEBRA RD. 78238-5166 • P.O. DRAWER $28510 \quad 78228-0510$

san antonio, texas, usa • (210)684-5111 • WWW.sWri.org CHEMISTRY AND CHEMICAL ENGINEERING DIVISION FIRE TECHNOLOGY DEPARTMENT WWW.FIRE.SWRI.ORG FAX (210) 522-3377

FIRE PERFORMANCE EVALUATION OF RESORCINOLFORMALDEHYDE POLYMER TESTED IN ACCORDANCE WITH ASTM D 7309-07a, STANDARD TEST METHOD FOR DETERMINING FLAMMABILITY CHARACTERISTICS OF PLASTICS AND OTHER SOLID MATERIALS USING MICROSCALE COMBUSTION CALORIMETERY

FINAL REPORT

Consisting of 15 Pages

SwRI ${ }^{\circledR}$ Project No. 01.13295.12.008d

Test Dates: November 16-18, 2011

Report Date: December 16, 2011

Prepared for:

Battelle Memorial Institute

902 Battelle Blvd, K6-79

P.O. Box 999

Richland, WA 99352

Prepared by:

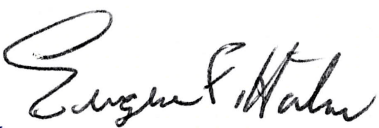

(Eugene F. Horton

Senior Engineering Technologist

Material Flammability Section

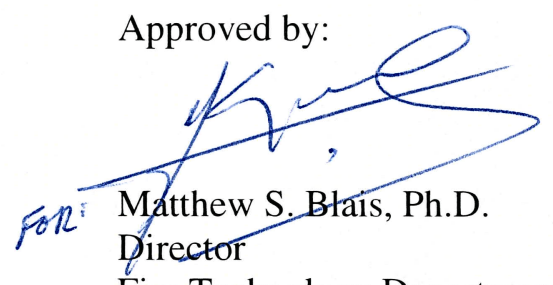

This report is for the information of the client. It may be used in its entirety for the purpose of securing product acceptance from duly constituted approval authorities. This report shall not be reproduced except in full, without the written approval of SwRI. Neither this report nor the name of the Institute shall be used in publicity or advertising 


\subsection{INTRODUCTION}

This report describes a small-scale fire test conducted on a material identified as ResorcinolFormaldehyde Polymer in accordance with ASTM D 7309-07a, Standard Test Method for Determining Flammability Characteristics of Plastics and Other Solid Materials Using Microscale Combustion Calorimetry, (Test Method A), for Battelle Memorial Institute, located in Richland, Washington. Testing was performed on the test samples in accordance with the quality assurance requirements of the DOE/RL-96-68, Hanford Analytical Services Quality Assurance Requirements Documents, Volumes 1 and 4 (HASQARDS), latest revision. In accordance with the HASQARDs, a positive, a negative, and duplicate tests were run, in addition to the one standard test. Testing was conducted on November 16-18, 2011, at the Fire Technology Department of Southwest Research Institute (SwRI), located in San Antonio, Texas.

The positive tests were performed on PMMA (Poly methyl methacrylate). This is a know standard used in testing and it was selected as the positive standard. The negative tests were performed on marinate board, which is a non-combustible material. This material often is used as a substrate or backer board in standard fire testing. It does not react to flame or heat except to lose moisture.

The test method described in ASTM D 7309-07a is intended to measure and describe the properties of materials or products in response to heat and flame under controlled laboratory conditions. The results should not be used alone to describe or appraise the fire hazard or the fire risk of materials, products, or assemblies under actual fire conditions. However, results of this test may be used as elements of a complete fire hazard for fire risk assessment, which takes into account all the factors that are pertinent to an assessment of the fire hazard or risk of a particular end-use.

The results presented in this report apply specifically to the specimens tested, in the manner tested, and not to the entire production of these or similar materials, nor to the performance when used in combination with other materials.

\subsection{DESCRIPTION OF TEST APPARATUS AND PROCEDURE}

The Microscale Combustion Calorimeter is a sophisticated small-scale test apparatus, which measures the rate of heat release of materials and products using the oxygen consumption technique.

For organic solids, liquids, and gases a nearly constant net amount of heat is released per unit mass of oxygen consumed for complete combustion. An average value for this constant of 13.1 MJ/kg of $\mathrm{O}_{2}$ can be used for practical applications and is accurate with very few exceptions to within $\pm 5 \%$. Therefore, measurements of the oxygen consumed in a combustion system can be used to determine the net heat released. This technique, generally referred to as the "oxygen consumption 
technique", is now the most widely used and accurate method for measuring heat release rate in experimental fires.

The ASTM D 7309-07a apparatus (see Figure 1) consists primarily of two heating chambers and a specimen holder (a part of the specimen thermocouple post). The heating chambers are two sections of a vertical tube; the sample sits in the pyrolysing chamber, and the pyrolysis gases move up towards the combustor chamber.

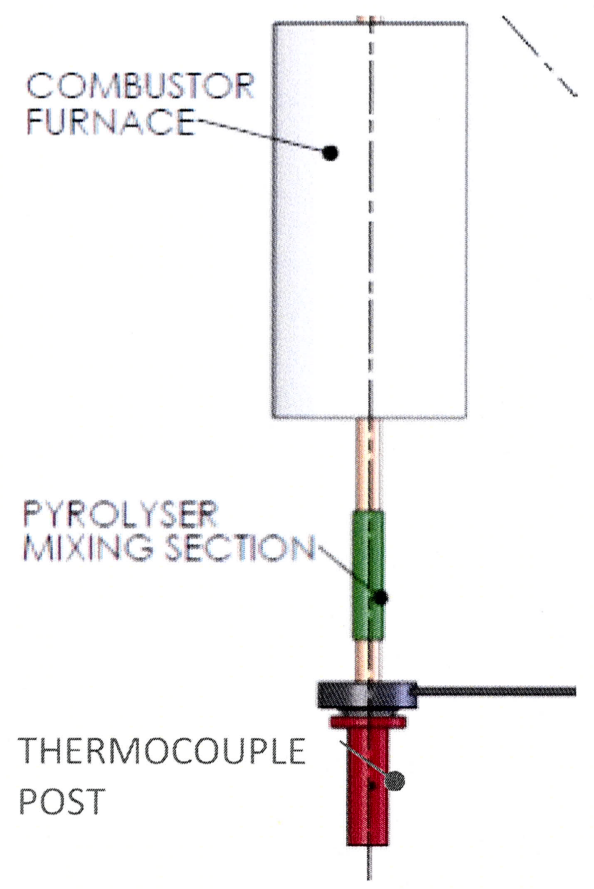

Figure 1. Schematic of Microcalorimeter.

The combustor chamber is typically set at $900{ }^{\circ} \mathrm{C}$. The pyrolysis chamber is set at $75{ }^{\circ} \mathrm{C}$ and is ramped up to $850{ }^{\circ} \mathrm{C}$ at a specified heating rate $\beta$, which is typically set to $1 \mathrm{~K} / \mathrm{s}$. The ASTM D 7309-07a specifies two different test methods: Method A is controlled thermal decomposition, and Method B is controlled thermal oxidative decomposition. The primary difference between the two methods is where the oxygen is introduced. In Method A, the purge gas nitrogen flows through the pyrolyser section then mixes with oxygen and the nitrogen/oxygen mixture along with any pyrolysis gases from the sample travel through the combustor furnace. In this method, the heat of combustion of the volatile components (gases) is measured, but not the heat of combustion of any solid residue. In Method B, the nitrogen/oxygen mixture is introduced into the pyrolyser section. In this method, the net calorific value of the specimen gases and solid residue are measured. Because Method A can be used to obtain the heat release capacity $\eta_{c}(\mathrm{~J} / \mathrm{g}-\mathrm{K})$, which is a flammability parameter unique to this test method, Method A is typically used. 
The heat release rate is calculated based on oxygen consumption, and the specimen mass loss is determined based on weight measurements before and after testing.

\subsection{DESCRIPTION OF TEST SPECIMENS}

Battelle Memorial Institute provided one 10 liter bottle of specimen, identified as ResorcinolFormaldehyde Polymer, and it was received by SwRI on November 11, 2011. A description of the material provided by the Client can be found in Table 1 .

Table 1. Test Sample Description Provided by the Client.

\begin{tabular}{|c|c|c|}
\hline Material ID & Sample Description & Color \\
\hline Resorcinol-Formaldehyde Polymer & Micro Beads & Red \\
\hline
\end{tabular}

Prior to testing, the specimen was prepared in accordance with the standard to an approximate weight of $3 \mathrm{~g}$. The samples provided consisted of a micro bead material dispersed in water. The material was tested in worst case scenario, which is with the water removed. This process was achieved by first filtering the material and then drying it in an oven. After drying, the sample consisted of only the micro bead material; the beads became statically charged in the absence of the water medium and therefore, they were placed in a closed container after drying, in an effort not to lose any beads. Each sample was then conditioned in a controlled environment maintained at $23{ }^{\circ} \mathrm{C} \pm 3{ }^{\circ} \mathrm{C}$ and $50 \% \pm 5 \%$ relative humidity until just prior to testing.

\subsection{TEST RESULTS}

Triplicate testing was conducted on November 16-18, 2011, by Nathaniel Ramos and Alan Lowry. Tabular test data and graphs of the measured heat release plotted with respect to temperatures and time are presented in Appendix A. 
APPENDIX A

\section{Microcalorimeter Data SHEetS}

(Consisting of 10 Pages) 


\section{MICROCALORIMETER TEST REPORT}

Client:

Battelle Memorial Institute

SwRI Project No:

$01.13295 .12 .008 \mathrm{~d}$

Material ID: See Notes

Preparation: November 16,2011

Test Method:

ASTM D7309/A

Heating Rate:

$1 \mathrm{~K} / \mathrm{S}$

Temperature Range:

Operator:

$75{ }^{\circ} \mathrm{C}-750{ }^{\circ} \mathrm{C}$

Nathaniel Ramos

\begin{tabular}{|c|c|c|c|c|c|c|c|c|c|}
\hline Test ID & Test Date & $\begin{array}{c}\text { Initial } \\
\text { M ass (g) }\end{array}$ & $\begin{array}{c}\text { Final } \\
\text { Mass (g) }\end{array}$ & $\begin{array}{l}\text { Qmax } \\
(\mathrm{W} / \mathrm{g})\end{array}$ & $\begin{array}{c}\text { Tmax } \\
(\mathrm{K})\end{array}$ & $\begin{array}{c}\eta \\
(\mathrm{J} / \mathrm{g}-\mathrm{K})\end{array}$ & $\begin{array}{c}\mathrm{hc} \\
(\mathrm{J} / \mathrm{g})\end{array}$ & $\begin{array}{c}Y p \\
(g / g)\end{array}$ & $\begin{array}{c}\mathrm{hc} \text {, gas } \\
\left(\mathrm{kW} / \mathrm{m}^{2}\right)\end{array}$ \\
\hline 11-320PNNL-1 & November 17, 2011 & 2.65 & 2.65 & 9.668 & 1009.775 & 9.668 & 3350.30425 & 1 & - \\
\hline 11-320PNNL-2 & November 17, 2011 & 2.46 & 0 & 383.783 & 673.684 & 383.783 & 27652.6835 & 0 & 27652.68 \\
\hline \multicolumn{2}{|c|}{ Average } & 2.555 & 1.325 & 196.726 & 841.7295 & 196.7255 & 15501.4939 & 0.5 & 27652.68 \\
\hline
\end{tabular}
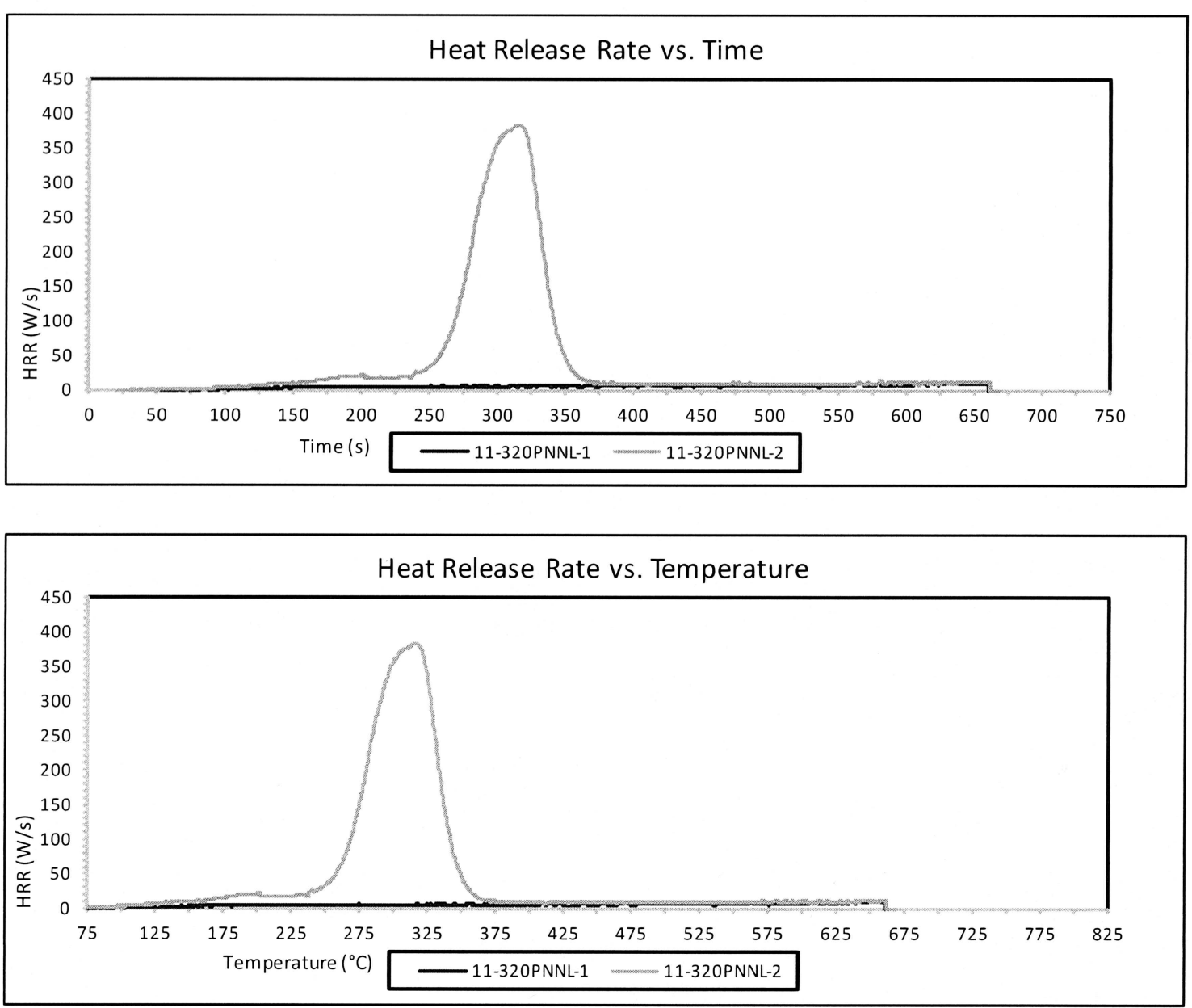

NOTES:

Silver: 11-320PNNL-1

PMMA: 11-320PNNL-2 


\section{MICROCALORIMETER TEST REPORT}

Client: Battelle Memorial Institute

Material ID: Resorcinol-Formaldehyde Polymer

Preparation: November 17, 2011
SwRI Project No: $\quad 01.13295 .12 .008 \mathrm{~d}$

Test Method: $\quad$ ASTM D7309/A

Heating Rate: $\quad 1 \mathrm{~K} / \mathrm{S}$

Temperature Range: $75^{\circ} \mathrm{C}-750^{\circ} \mathrm{C}$

Operator: Nathaniel Ramos

\begin{tabular}{|c|c|c|c|c|c|c|c|c|c|}
\hline Test ID & Test Date & $\begin{array}{c}\text { Initial } \\
\text { Mass (g) }\end{array}$ & $\begin{array}{c}\text { Final } \\
\text { Mass (g) }\end{array}$ & $\begin{array}{l}\mathrm{Qmax} \\
(\mathrm{W} / \mathrm{g})\end{array}$ & $\begin{array}{c}\mathrm{T} \max \\
(\mathrm{K})\end{array}$ & $\begin{array}{c}\eta \\
(\mathrm{J} / \mathrm{g}-\mathrm{K})\end{array}$ & $\begin{array}{c}\mathrm{hc} \\
(\mathrm{J} / \mathrm{g})\end{array}$ & $\begin{array}{c}\mathrm{Yp} \\
(\mathrm{g} / \mathrm{g})\end{array}$ & $\begin{array}{l}\text { hc, gas } \\
\left(\mathrm{kW} / \mathrm{m}^{2}\right)\end{array}$ \\
\hline 11-320PNNL-3 & November 16, 2011 & 2.55 & 1.45 & 25.944 & 898.249 & 25.944 & 6373.7685 & 0.568627 & 14775.55 \\
\hline 11-320PNNL-4 & November 16, 2011 & 2.43 & 1.44 & 23.734 & 939.012 & 23.734 & 7079.18325 & 0.592593 & 17376.18 \\
\hline \multicolumn{2}{|c|}{ Average } & 2.49 & 1.445 & 24.839 & 918.6305 & 24.839 & 6726.47588 & 0.58061 & 16075.87 \\
\hline
\end{tabular}
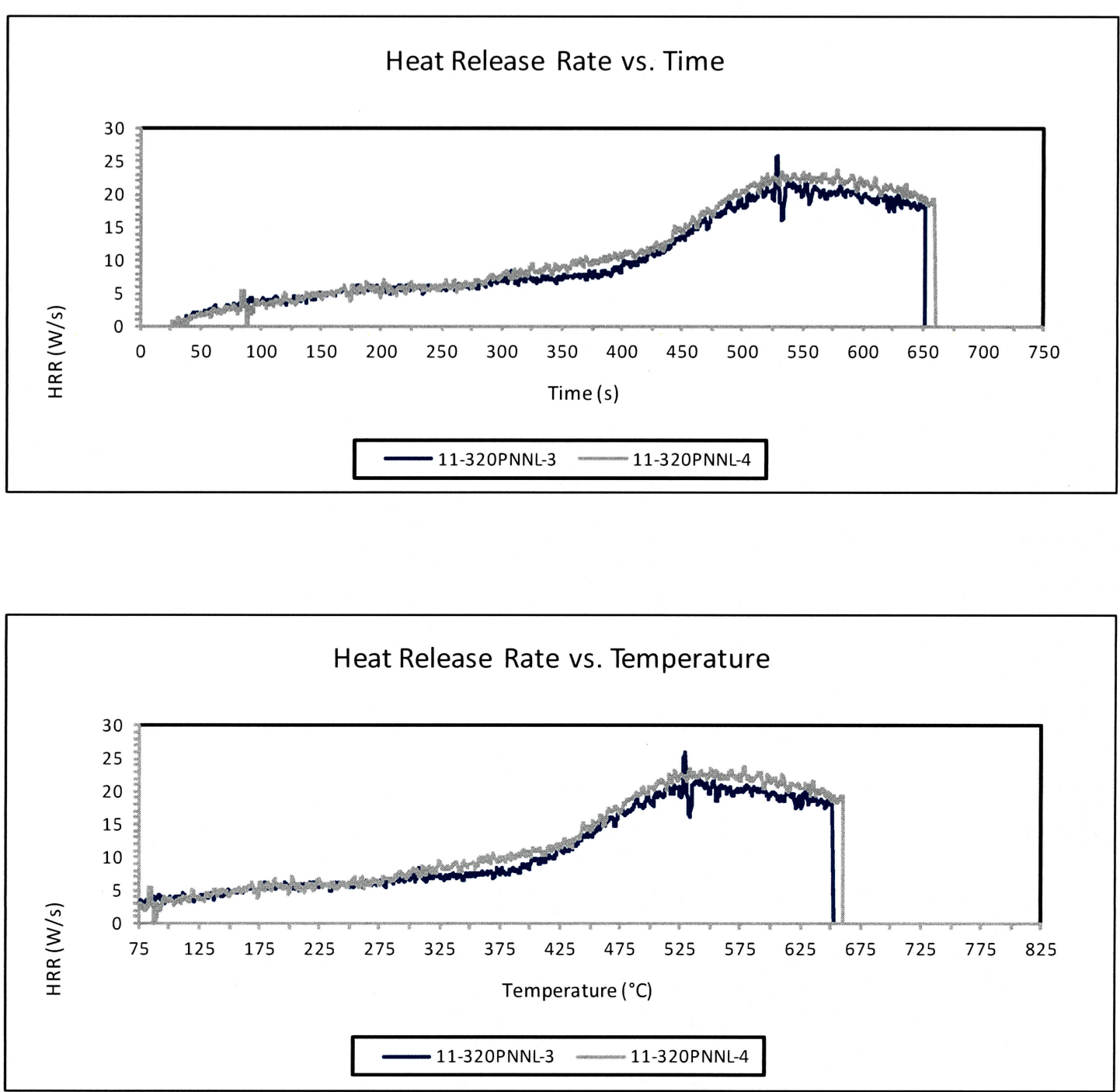


\section{MICROCALORIMETER TEST REPORT}

Client:

Material ID:

Preparation:
Battelle Memorial Institute

Resorcinol-Formaldehyde Polymer

November 17, 2011
SwRI Project No:

Test Method:

Heating Rate:

Temperature Range:

Operator: 01.13295.12.008d ASTM D7309/A

$1 \mathrm{~K} / \mathrm{S}$

$75{ }^{\circ} \mathrm{C}-750{ }^{\circ} \mathrm{C}$

Nathaniel Ramos

\begin{tabular}{|c|c|c|c|c|c|c|c|c|c|}
\hline Test ID & Test Date & $\begin{array}{c}\text { Initial } \\
\text { Mass (g) }\end{array}$ & $\begin{array}{c}\text { Final } \\
\text { Mass (g) }\end{array}$ & $\begin{array}{l}\text { Qmax } \\
(\mathrm{W} / \mathrm{g})\end{array}$ & $\begin{array}{c}\mathrm{T} \max \\
(\mathrm{K})\end{array}$ & $\begin{array}{c}\eta \\
(\mathrm{J} / \mathrm{g}-\mathrm{K})\end{array}$ & $\begin{array}{c}\text { hc } \\
(\mathrm{J} / \mathrm{g})\end{array}$ & $\begin{array}{c}\mathrm{Yp} \\
(\mathrm{g} / \mathrm{g})\end{array}$ & $\begin{array}{c}\text { hc, gas } \\
\left(\mathrm{kW} / \mathrm{m}^{2}\right)\end{array}$ \\
\hline 11-321PNNL-1 & November 17,2011 & 2.46 & 1.39 & 17.509 & 904.262 & 17.509 & 2060.3068 & 0.565041 & 4736.78 \\
\hline 11-321PNNL-2 & November 17, 2011 & 2.33 & 1.4 & 13.228 & 917.423 & 13.228 & 1173.086 & 0.600858 & 2939.02 \\
\hline$A v$ & age & 2.395 & 1.395 & 15.3685 & 910.843 & 15.3685 & 1616.6964 & 0.58295 & 3837.9 \\
\hline
\end{tabular}
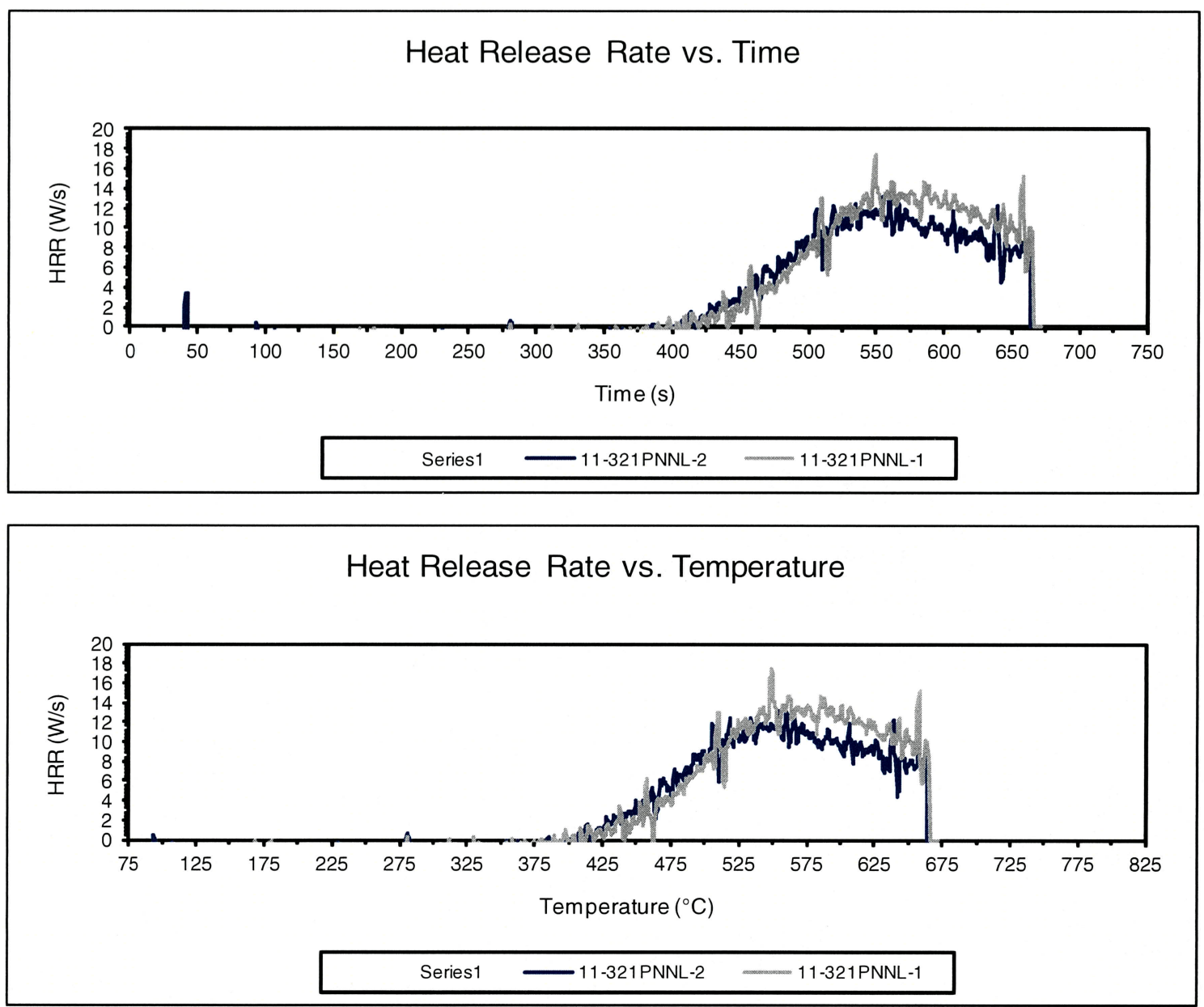

Note: Duplicate Run 


\section{MICROCALORIMETER TEST REPORT}

Client:

Material ID:

Preparation:
Battelle Memorial Institute

Resorcinol-Formaldehyde Polymer

November 17, 2011
SwRI Project No:

Test Method:

Heating Rate:

Temperature Range:

Operator:
$01.13295 .12 .008 \mathrm{~d}$ ASTM D7309/A $1 \mathrm{~K} / \mathrm{S}$

$75^{\circ} \mathrm{C}-750{ }^{\circ} \mathrm{C}$

Nathaniel Ramos

\begin{tabular}{|c|c|c|c|c|c|c|c|c|}
\hline Test Date & $\begin{array}{c}\text { Initial } \\
\text { Mass (g) }\end{array}$ & $\begin{array}{c}\text { Final } \\
\text { Mass (g) }\end{array}$ & $\begin{array}{l}\text { Qmax } \\
(\mathrm{W} / \mathrm{g})\end{array}$ & $\begin{array}{c}\mathrm{T} \max \\
(\mathrm{K})\end{array}$ & $\begin{array}{c}\eta \\
(J / g-K)\end{array}$ & $\begin{array}{c}\text { hc } \\
(\mathrm{J} / \mathrm{g})\end{array}$ & $\begin{array}{c}\mathrm{Yp} \\
(\mathrm{g} / \mathrm{g}) \\
\end{array}$ & $\begin{array}{c}\text { hc, gas } \\
\left(\mathrm{kW} / \mathrm{m}^{2}\right)\end{array}$ \\
\hline 11-321PNNL-4 November 17, 2011 & 2.58 & 1.54 & 22.172 & 914.779 & 22.172 & 6292.5048 & 0.596899 & 15610.3 \\
\hline 11-321PNNL-3 November 17, 2011 & 2.58 & 1.44 & 27.092 & 952.411 & 27.092 & 5244.4058 & 0.55814 & 11868.9 \\
\hline Average & 2.58 & 1.49 & 24.632 & 933.595 & 24.632 & 5768.4553 & 0.577519 & 13739.6 \\
\hline
\end{tabular}
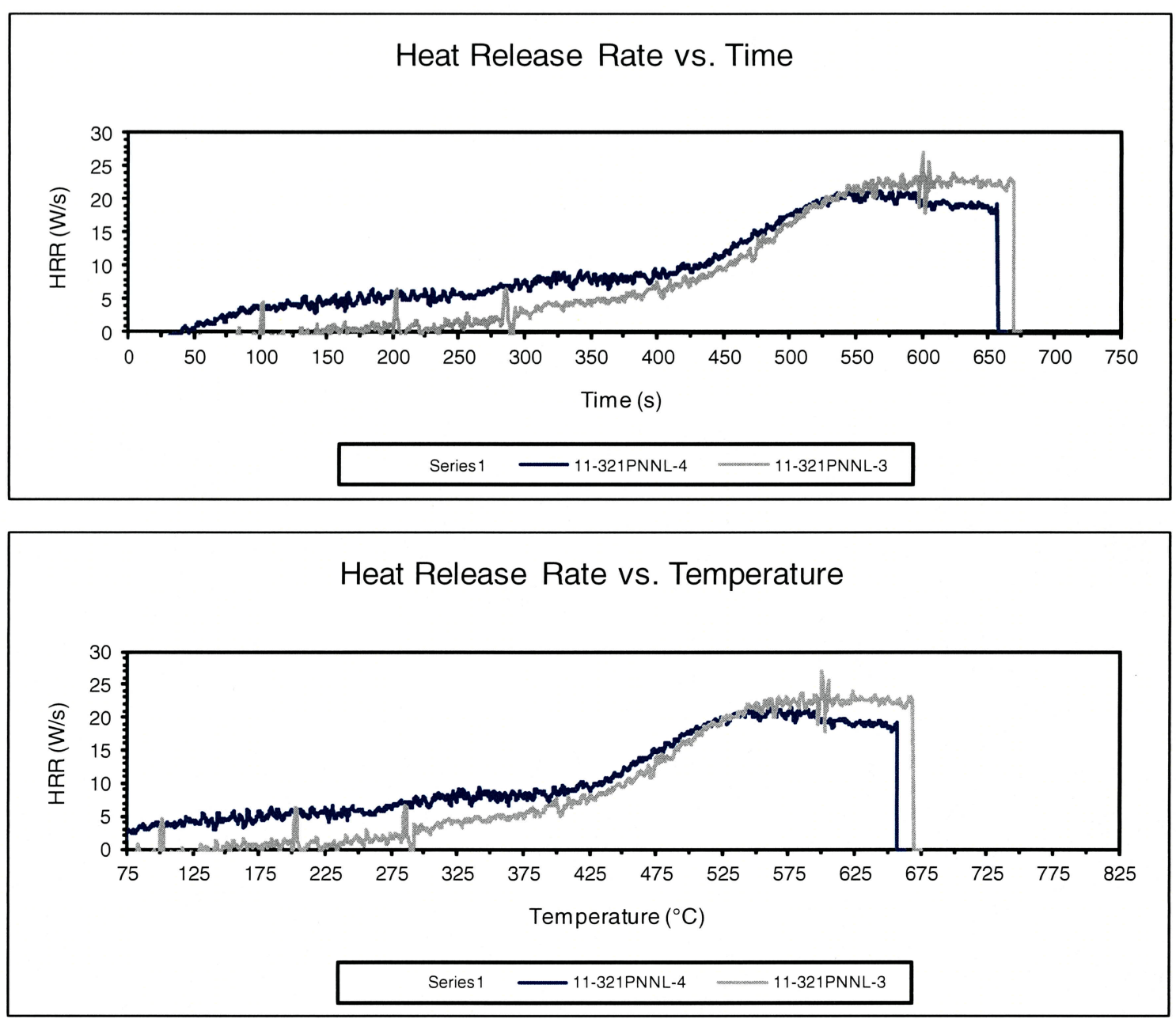


\section{MICROCALORIMETER TEST REPORT}

Client: Battelle Memorial Institute

Material ID: Silver, Negative Standard

Preparation: November 17, 2011
SwRI Project No:

Test Method:

Heating Rate:

Temperature Range:

Operator:
$01.13295 .12 .008 \mathrm{~d}$

ASTM D7309/B

$1 \mathrm{~K} / \mathrm{S}$

$75^{\circ} \mathrm{C}-750{ }^{\circ} \mathrm{C}$

Nathaniel Ramos

\begin{tabular}{|cccccccccc|}
\hline \multirow{2}{*}{ Test ID } & Test Date & $\begin{array}{c}\text { Initial } \\
\text { Mass }(\mathrm{g})\end{array}$ & $\begin{array}{c}\text { Final } \\
\text { Mass }(\mathrm{g})\end{array}$ & $\begin{array}{c}\text { Qmax } \\
(\mathrm{W} / \mathrm{g})\end{array}$ & $\begin{array}{c}\text { Tmax } \\
(\mathrm{K})\end{array}$ & $\begin{array}{c}\eta \\
(\mathrm{J} / \mathrm{g}-\mathrm{K})\end{array}$ & $\begin{array}{c}\mathrm{hc} \\
(\mathrm{J} / \mathrm{g})\end{array}$ & $\begin{array}{c}\mathrm{Yp} \\
(\mathrm{g} / \mathrm{g})\end{array}$ & $\begin{array}{c}\mathrm{hc}, \text { gas } \\
\left(\mathrm{kW} / \mathrm{m}^{2}\right)\end{array}$ \\
\hline 11-321PNNL-5 November 17, 2011 & 2.65 & 2.65 & 0 & 1021.63 & 0 & -27.55975 & 1 & - \\
& & & & & & & & \\
& & & & & & & & & \\
& & & & & & & & & \\
\hline
\end{tabular}
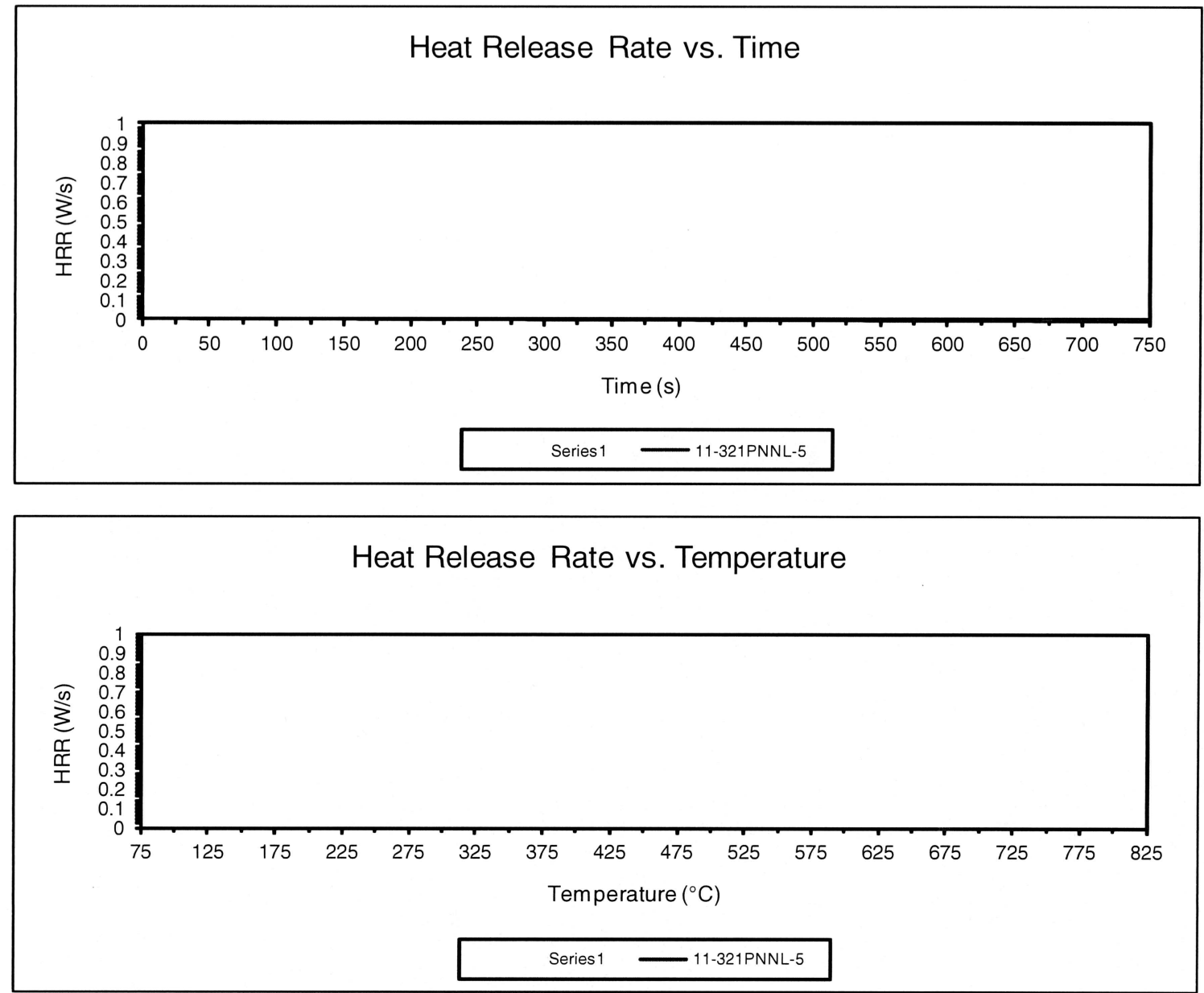


\section{MICROCALORIMETER TEST REPORT}

Client:

Battelle Memorial Institute

Material ID:

Preparation:

\section{PMMA, Positive Standard}

November 17, 2011
SwRI Project No:

Test Method:

Heating Rate:

Temperature Range:

Operator:
$01.13295 .12 .008 \mathrm{~d}$

ASTM D7309/B

$1 \mathrm{~K} / \mathrm{S}$

$75^{\circ} \mathrm{C}-750{ }^{\circ} \mathrm{C}$

Nathaniel Ramos

\begin{tabular}{|c|c|c|c|c|c|c|c|c|}
\hline Test Date & $\begin{array}{c}\text { Initial } \\
\text { Mass (g) }\end{array}$ & $\begin{array}{c}\text { Final } \\
\text { Mass (g) }\end{array}$ & $\begin{array}{l}\text { Qmax } \\
(\mathrm{W} / \mathrm{g})\end{array}$ & $\begin{array}{c}\mathrm{T} \max \\
(\mathrm{K})\end{array}$ & $\begin{array}{c}\eta \\
(J / g-K)\end{array}$ & $\begin{array}{c}\mathrm{hc} \\
(\mathrm{J} / \mathrm{g})\end{array}$ & $\begin{array}{c}\mathrm{Yp} \\
(\mathrm{g} / \mathrm{g})\end{array}$ & $\begin{array}{c}\text { hc, gas } \\
\left(\mathrm{kW} / \mathrm{m}^{2}\right)\end{array}$ \\
\hline 11-321PNNL-6 November 17, 2011 & 2.4 & 0 & 199.459 & 595.79 & 199.459 & 18347.795 & 0 & 18347.8 \\
\hline
\end{tabular}

\section{Heat Release Rate vs. Time}

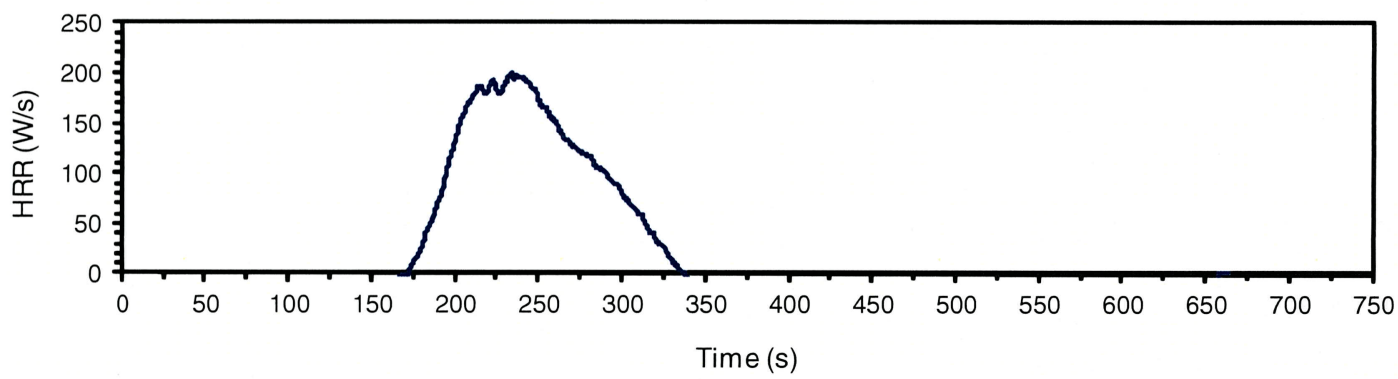

Series $1-11-321$ PNNL-6

Heat Release Rate vs. Temperature

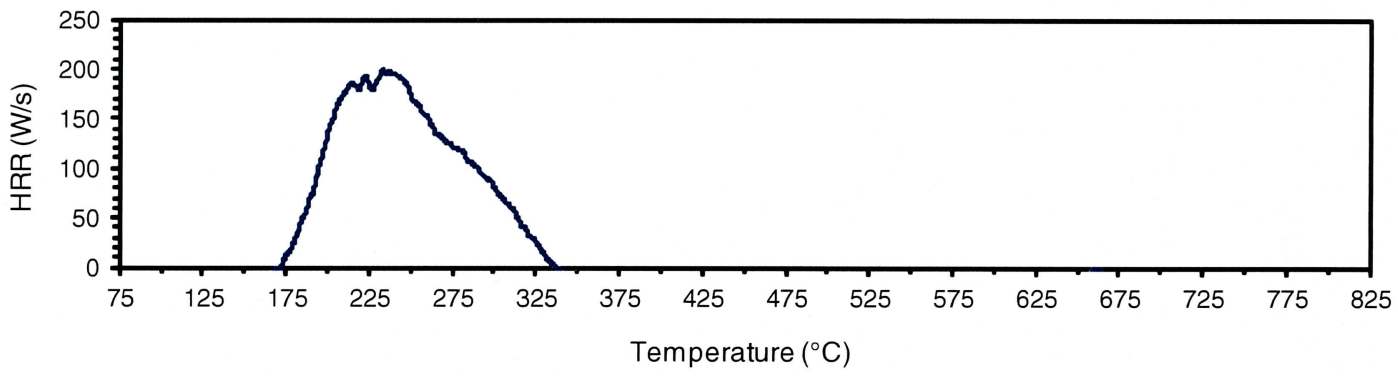

Series $1 \longrightarrow$ 11-321PNNL-6 


\section{MICROCALORIMETER TEST REPORT}

Client: Battelle Memorial Institute

Material ID: Resorcinol-Formaldehyde Polymer

Preparation: November 17,2011
SwRI Project No:

Test Method:

Heating Rate:

Temperature Range:

Operator:
$01.13295 .12 .008 \mathrm{~d}$

ASTM D7309/B

$1 \mathrm{~K} / \mathrm{S}$

$75^{\circ} \mathrm{C}-750{ }^{\circ} \mathrm{C}$

Nathaniel Ramos

\begin{tabular}{|c|c|c|c|c|c|c|c|c|c|}
\hline Test ID & Test Date & $\begin{array}{c}\text { Initial } \\
\text { M ass (g) }\end{array}$ & $\begin{array}{c}\text { Final } \\
\text { M ass }(\mathrm{g})\end{array}$ & $\begin{array}{l}\text { Qmax } \\
(W / g)\end{array}$ & $\begin{array}{l}\operatorname{Tmax} \\
(\mathrm{K})\end{array}$ & $\begin{array}{c}\eta \\
(J / g-K)\end{array}$ & $\begin{array}{c}\mathrm{hc} \\
(\mathrm{J} / \mathrm{g})\end{array}$ & $\begin{array}{l}\mathrm{Yp} \\
(\mathrm{g} / \mathrm{g})\end{array}$ & $\begin{array}{c}\mathrm{hc} \text {, gas } \\
\left(\mathrm{kW} / \mathrm{m}^{2}\right)\end{array}$ \\
\hline 11-321PNNL--7 & November 17,2011 & 2.34 & 0 & 122.904 & 838.435 & 122.904 & 13034.482 & 0 & 13034.5 \\
\hline & erage & 2.34 & 0 & 122.904 & 838.435 & 122.904 & 13034.482 & 0 & 13034.5 \\
\hline
\end{tabular}
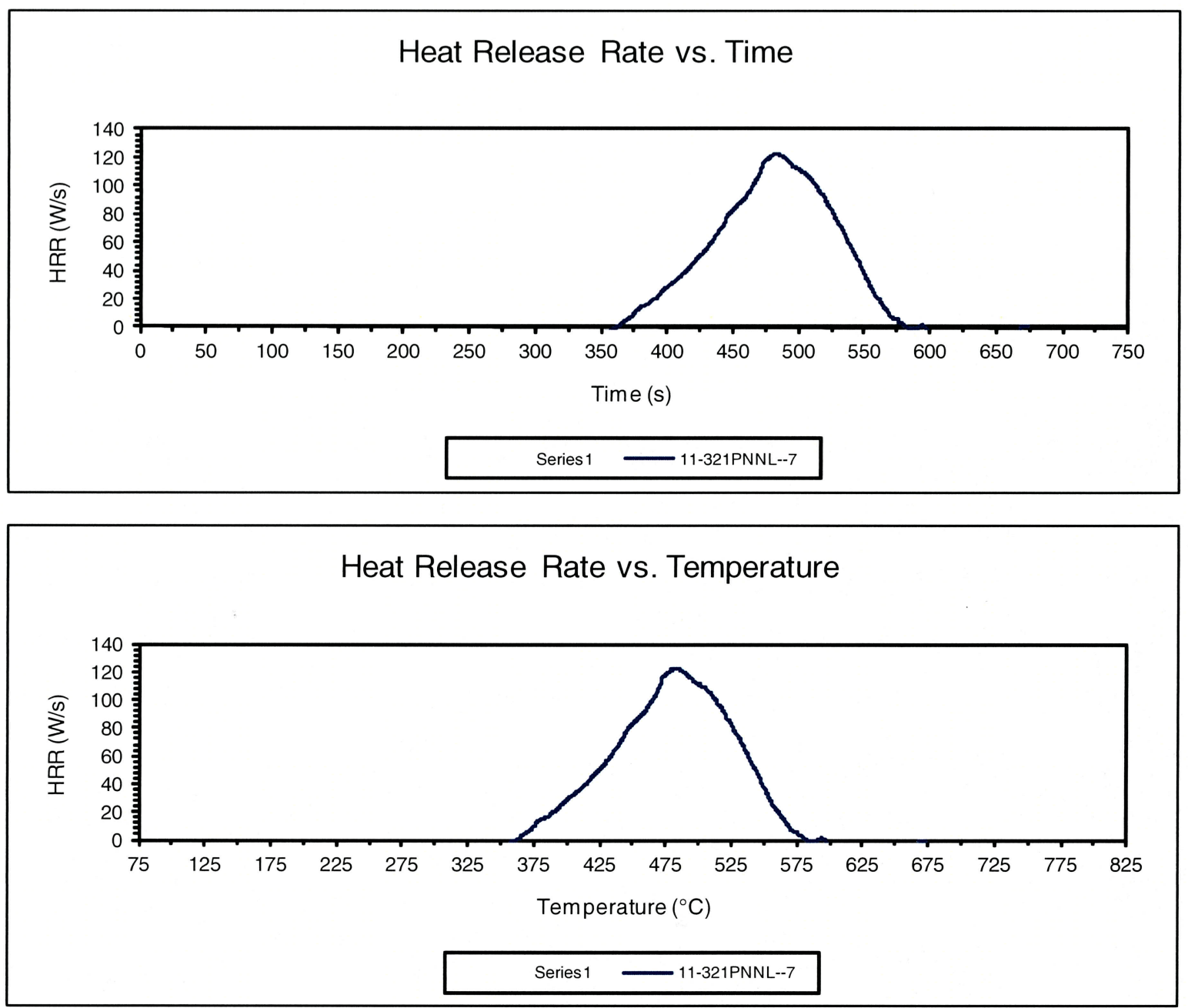


\section{MICROCALORIMETER TEST REPORT}

Client:

Material ID:

Preparation:
Battelle Memorial Institute

Resorcinol-Formaldehyde Polymer

November 18, 2011
SwRI Project No:

Test Method:

Heating Rate:

Temperature Range:

Operator:
$01.13295 .12 .008 \mathrm{~d}$ ASTM D7309/B

$1 \mathrm{~K} / \mathrm{S}$

$75{ }^{\circ} \mathrm{C}-750{ }^{\circ} \mathrm{C}$

Alan Lowry

\begin{tabular}{|c|c|c|c|c|c|c|c|c|}
\hline Test Date & $\begin{array}{c}\text { Initial } \\
\text { Mass (g) }\end{array}$ & $\begin{array}{c}\text { Final } \\
\text { Mass (g) }\end{array}$ & $\begin{array}{l}\text { Qmax } \\
(\mathrm{W} / \mathrm{g})\end{array}$ & $\begin{array}{c}\mathrm{T} \max \\
(\mathrm{K}) \\
\end{array}$ & $\begin{array}{c}\eta \\
(J / g-K)\end{array}$ & $\begin{array}{c}\mathrm{hc} \\
(\mathrm{J} / \mathrm{g}) \\
\end{array}$ & $\begin{array}{c}\mathrm{Yp} \\
(\mathrm{g} / \mathrm{g}) \\
\end{array}$ & $\begin{array}{c}\text { hc, gas } \\
\left(\mathrm{kW} / \mathrm{m}^{2}\right)\end{array}$ \\
\hline 11-321PNNL-8 November 17, 2011 & 2.46 & 0 & 126.902 & 847.799 & 126.902 & 13696.4295 & 0 & 13696.4 \\
\hline 11-321PNNL-9 November 17, 2011 & 2.42 & 0 & 133.069 & 831.371 & 133.069 & 13392.585 & 0 & 13392.6 \\
\hline Average & 2.44 & 0 & 129.986 & 839.585 & 129.9855 & 13544.5073 & 0 & 13544.5 \\
\hline
\end{tabular}

\section{Heat Release Rate vs. Time}

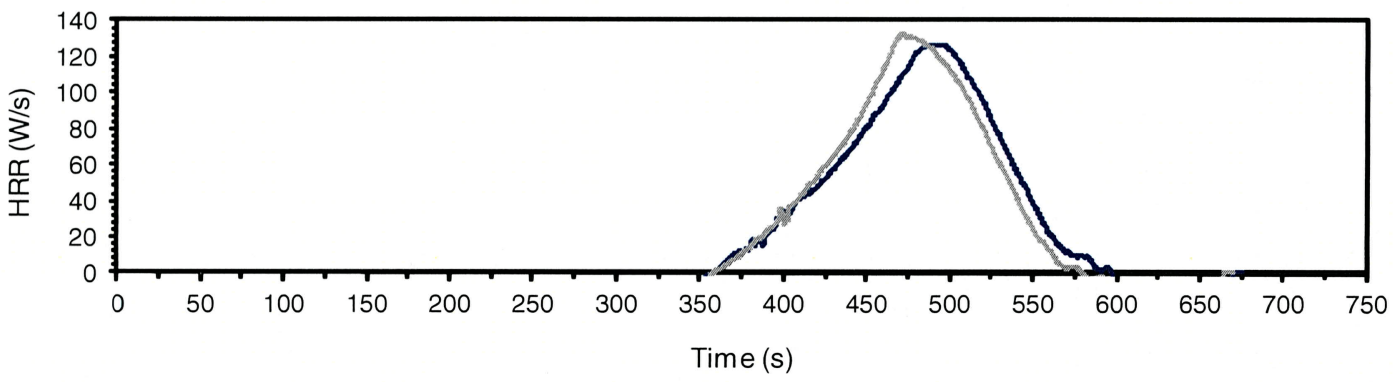

Series1 $-11-321 \mathrm{PNNL}-8 \longrightarrow$ 11-321PNNL-9

\section{Heat Release Rate vs. Temperature}

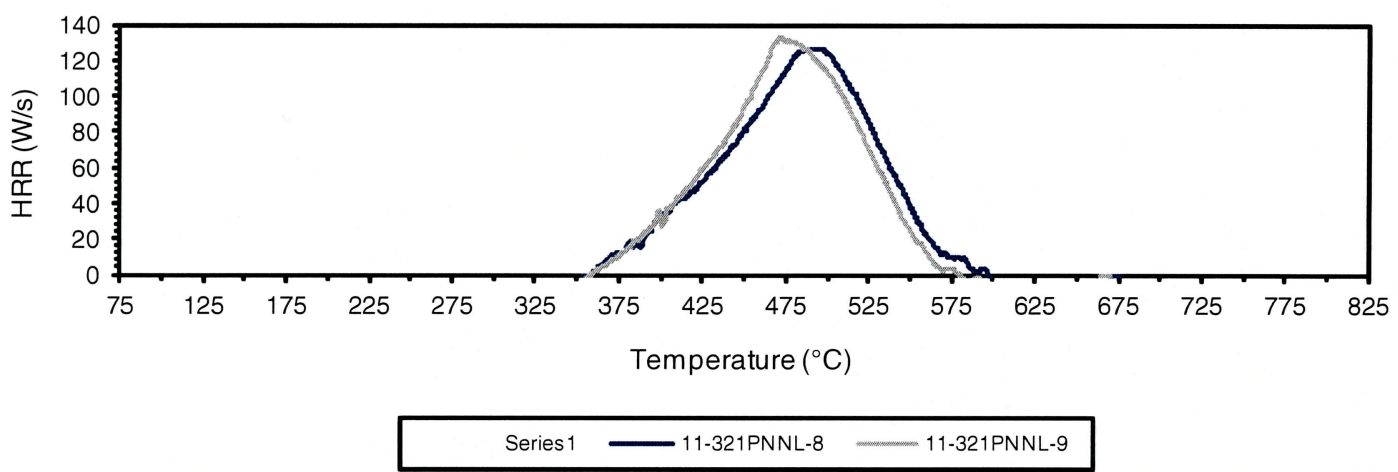




\section{MICROCALORIMETER TEST REPORT}

Client: $\quad$ Battelle Memorial Institute

Material ID: Resorcinol-Formaldehyde Polymer

Preparation: November 18, 2011
SwRI Project No: $\quad 01.13295 .12 .008 \mathrm{~d}$

Test Method: $\quad$ ASTM D7309/B

Heating Rate: $\quad 1 \mathrm{~K} / \mathrm{S}$

Temperature Range: $75^{\circ} \mathrm{C}-750{ }^{\circ} \mathrm{C}$

Operator: Alan Lowry

\begin{tabular}{|cccccccccc|}
\hline \multirow{2}{*}{ Test ID } & \multirow{2}{*}{ Test Date } & $\begin{array}{c}\text { Initial } \\
\text { Mass }(\mathrm{g})\end{array}$ & $\begin{array}{c}\text { Final } \\
\text { Mass }(\mathrm{g})\end{array}$ & $\begin{array}{c}\text { Qmax } \\
(\mathrm{W} / \mathrm{g})\end{array}$ & $\begin{array}{c}\text { Tmax } \\
(\mathrm{K})\end{array}$ & $\begin{array}{c}\eta \\
(\mathrm{J} / \mathrm{g}-\mathrm{K})\end{array}$ & $\begin{array}{c}\mathrm{hc} \\
(\mathrm{J} / \mathrm{g})\end{array}$ & $\begin{array}{c}\text { Yp } \\
(\mathrm{g} / \mathrm{g})\end{array}$ & $\begin{array}{c}\text { hc, gas } \\
\left(\mathrm{kW} / \mathrm{m}^{2}\right)\end{array}$ \\
\hline 11-322PNNL-11 & $11 / 18 / 18$ & 2.63 & 0 & 116.627 & 836.752 & 116.627 & 12980.497 & 0 & 12980.5 \\
$\mathbf{1 1 - 3 2 2 P N N L - 1 0}$ & $\mathbf{1 1 / 1 8 / 1 8}$ & $\mathbf{2 . 5}$ & $\mathbf{0}$ & $\mathbf{3 7 . 9 7 5}$ & $\mathbf{8 5 6 . 4 0 1}$ & $\mathbf{3 7 . 9 7 5}$ & $\mathbf{1 5 0 9 . 7 2 2 3}$ & $\mathbf{0}$ & $\mathbf{1 5 0 9 . 7 2 2}$ \\
& & & & & & & & & \\
& & & & & & & & & \\
\hline \multicolumn{2}{c}{ Average } & 2.565 & 0 & 77.301 & 846.5765 & 77.301 & 7245.1095 & 0 & 7245.11 \\
\hline
\end{tabular}
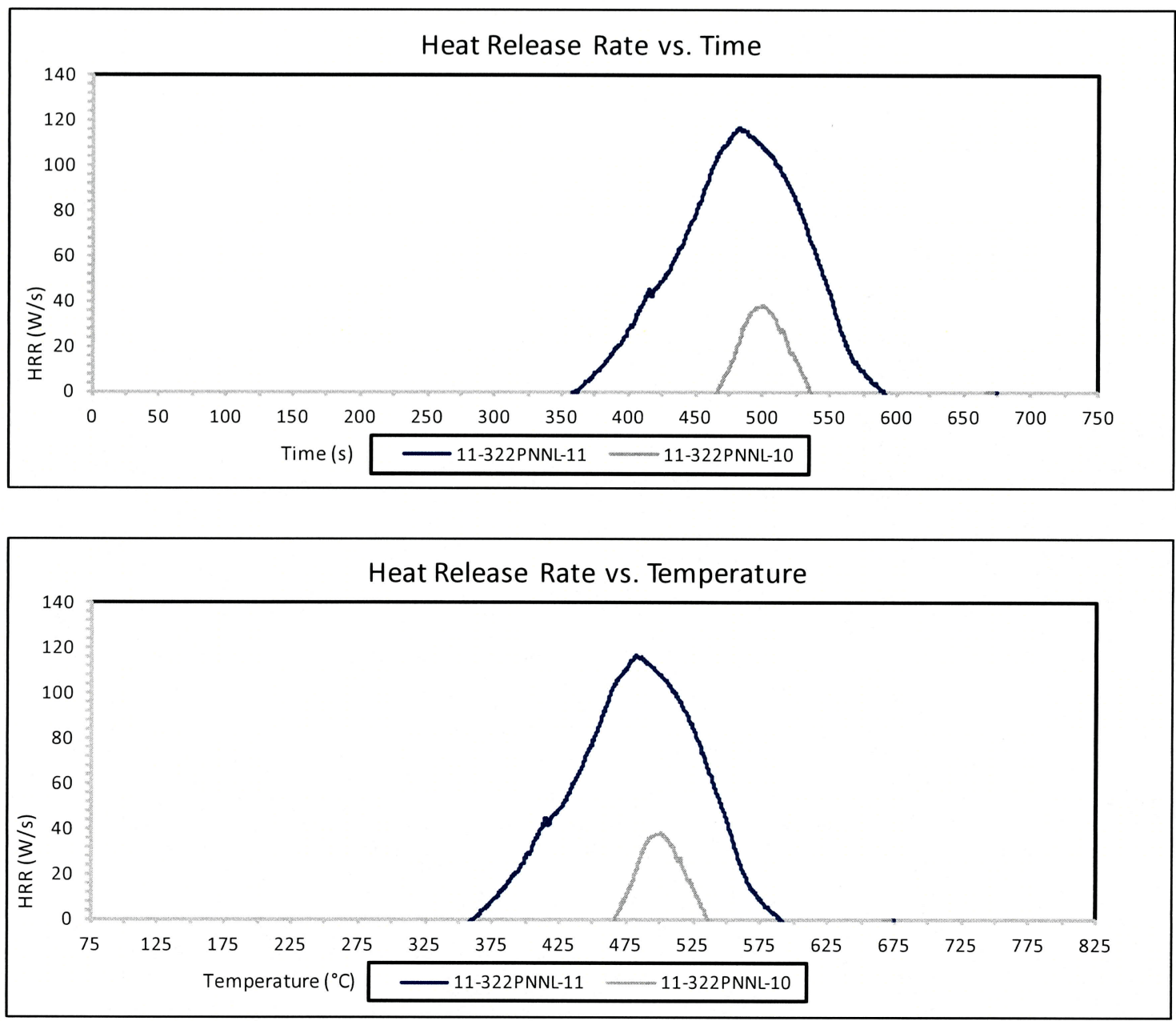

NOTE : 11-322PNNL-10 retested due to malfunction

QA Required Duplicate Run 


\section{MICROCALORIMETER TEST REPORT}

Client: $\quad$ Battelle Memorial Institute

Material ID:

Preparation:
Resorcinol-Formaldehyde Polymer

November 18, 2011
SwRI Project No:

Test Method:

Heating Rate:

Temperature Range:

Operator:
$01.13295 .12 .008 \mathrm{~d}$ ASTM D7309/B $1 \mathrm{~K} / \mathrm{S}$ $75{ }^{\circ} \mathrm{C}-750{ }^{\circ} \mathrm{C}$

Nathaniel Ramos

\begin{tabular}{|c|c|c|c|c|c|c|c|c|c|}
\hline Test ID & Test Date & $\begin{array}{c}\text { Initial } \\
\text { Mass (g) }\end{array}$ & $\begin{array}{c}\text { Final } \\
\text { Mass (g) }\end{array}$ & $\begin{array}{l}\text { Qmax } \\
(\mathrm{W} / \mathrm{g})\end{array}$ & $\begin{array}{c}\mathrm{T} \max \\
(\mathrm{K})\end{array}$ & $\begin{array}{c}\eta \\
(J / g-K)\end{array}$ & $\begin{array}{c}\mathrm{hc} \\
(\mathrm{J} / \mathrm{g})\end{array}$ & $\begin{array}{c}Y p \\
(g / g)\end{array}$ & $\begin{array}{c}\text { hc, gas } \\
\left(\mathrm{kW} / \mathrm{m}^{2}\right)\end{array}$ \\
\hline 11-322PNNL-13 & November 18, 2011 & 2.5 & 0 & 124.447 & 838.97 & 124.447 & 12437.639 & 0 & 12437.64 \\
\hline 11-322PNNL-12 & November 18, 2011 & 2.51 & 0 & 123.355 & 845.69 & 123.355 & 12689.77925 & 0 & 12689.78 \\
\hline
\end{tabular}
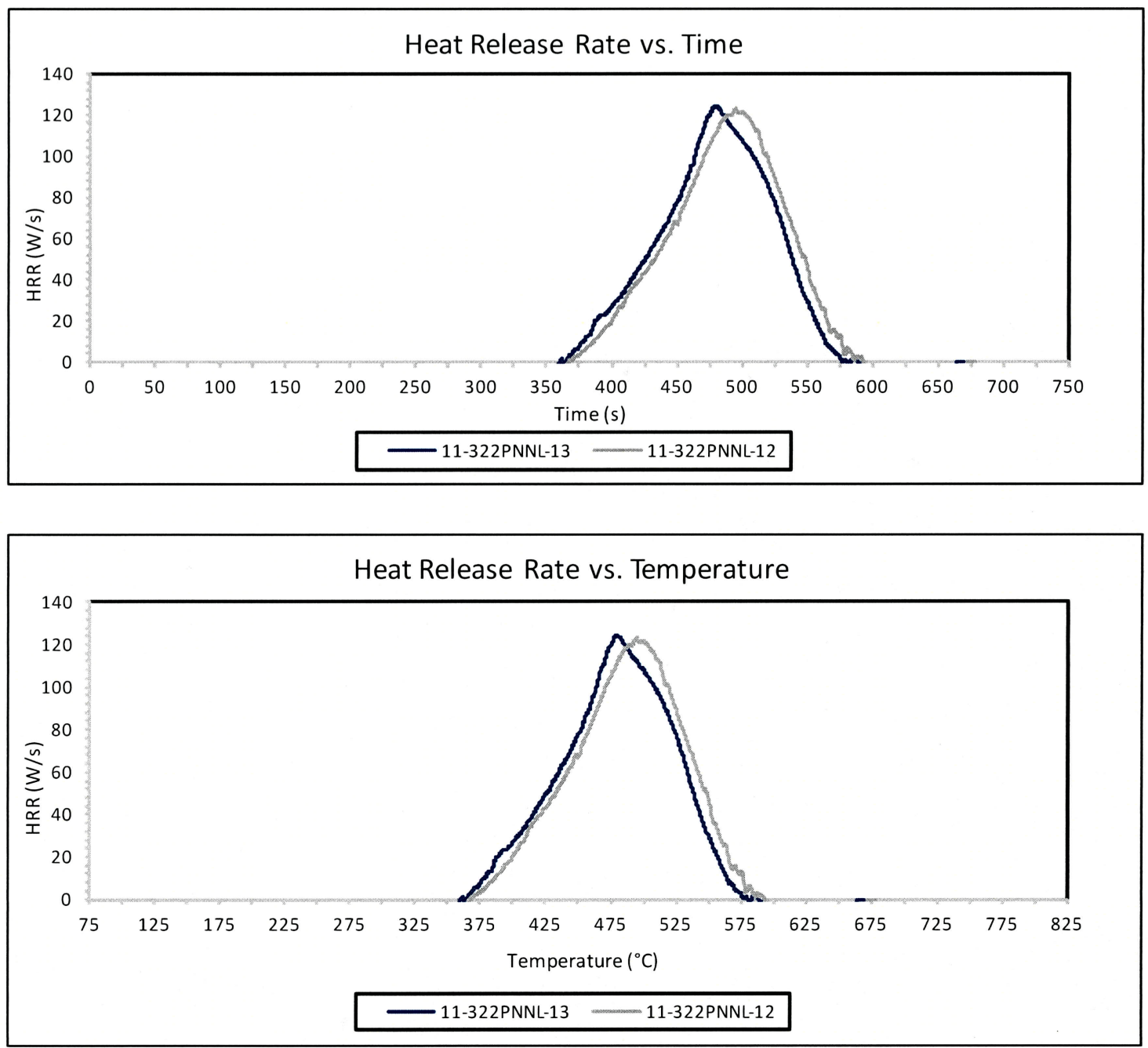

QA Required Duplicate Run 
SOUTHWEST RESEARCH INSTITUTE CLIENT: Battelle Memorial Ins. PNNL TASK ORDER\#:

111111-12

SRR\#: 46069

SDG\#:

479235

VTSR:

11/11/2011

PROJECT \#:

13295.12.00X

\section{R13295.12.008e (ASTM E 662 and ASTM E 800 Testing)}




\section{S O U T H W E T T R E E A R C H IN S T I T U T E ${ }^{\circledR}$}

6220 CULEBRA RD. 78238-5166 • P.O. DRAWER 28510 78228-0510 • SAN ANTONIO, TEXAS, USA • (210)684-5111 - WWW.SWRI.ORG CHEMISTRY AND CHEMICAL ENGINEERING DIVISION FIRE TECHNOLOGY DEPARTMENT WWW.FIRE.SWRI.ORG FAX (210) 522-3377

Laser Generated Particle Size and Count Evaluation in General ACCORDANCE WITH ASTM E 662-09, STANDARD TEST METHOD FOR SPECIFIC OPTICAL DENSITY OF SMOKE GENERATED BY SOLID MATERIALS, AND SUPPLEMENTED WITH TOXICITY Evaluation TESTED IN ACCORDANCE WITH ASTM E 800-07, STANDARD GUIDE FOR MEASUREMENT OF GASES PRESENT OR GENERATED DURING FIRES

MATERIAL ID: RESORCINOL-FORMALDEHYDE POLYMER

FINAL REPORT

Consisting of 7 Pages

SwRI ${ }^{(x)}$ Project No. 01.13295.12.008e

Test Dates: November 17-29, 2011

Report Date: December 16, 2011

Prepared for:

Battelle Memorial Institute

902 Battelle Blvd, K6-79

P.O. Box 999

Richland, WA 99352

Submitted by:

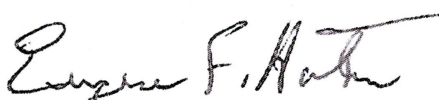

Eugene F. Horton

Senior Engineering Technologist

Material Flammability Section

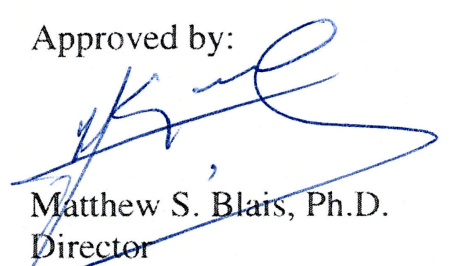

Fire Technology Department

This report is for the information of the Client. This report shall not be reproduced except in full, without the written approval of SwRI. Neither this report nor the name of the Institute shall be used in publicity or advertising. 


\subsection{INTRODUCTION}

This report presents the results of a particle count and size evaluation conducted at Southwest Research Institute's (SwRI) Fire Technology Department, located in San Antonio, Texas.

Testing was performed on the test samples in accordance with the quality assurance requirements of the DOE/RL-96-68, Hanford Analytical Services Quality Assurance Requirements Documents, Volumes 1 and 4 (HASQARDS), latest revision. In accordance with the HASQARDs, a positive, a negative, and a duplicate test were run, in addition to the one standard test.

The positive tests were performed in the flaming mode on a Schneller Standard Core Panel specimen measuring $75 \times 75 \times 10 \mathrm{~mm}$. The negative test was performed on calcium silicate specimen measuring $75 \times 75 \times 10 \mathrm{~mm}$, which is a non-combustible material. This material is often used as a substrate or backer board in standard fire testing. It does not react to flame or heat except to lose moisture, and; therefore, for particle size and count, it was used as a negative material test.

A radiant heat furnace was used to provide a constant irradiance of $25 \mathrm{~kW} / \mathrm{m}^{2}$ in a flaming exposures. The furnace used was not the same as prescribed in the ASTM E 662, Standard Test Method for Specific Optical Density of Smoke Generated by Solid Materials, standard. Because the material could not sit in the sample holder in a vertical orientation, the ISO 5659 furnace, a radiator cone, was used. The ISO 5659 is a similar smoke generation test which is typically run in the horizontal orientation. A pilot flame was used during flaming exposure and was centered in front of and parallel to the specimen holder. The pilot flame was also different from that described in the ASTM E 662, which is a six-flamelet pilot burner. Instead the ISO 5659, single pilot flame burner was used.

The samples provided consisted of a micro bead material dispersed in water. The material was tested in worst case scenario, which is with the water removed. This process was achieved by first filtering the material, and then drying it in an oven. The sample was predried for a minimum of $10 \mathrm{~h}$ at $60{ }^{\circ} \mathrm{C} \pm 3{ }^{\circ} \mathrm{C}\left(140{ }^{\circ} \mathrm{F} \pm 5^{\circ} \mathrm{F}\right)$ prior to testing. After drying, the sample consisted of only the microbead material; the beads became statically charged in the absence of the water medium and therefore, they were placed in a closed container after drying, in an effort not to lose any beads. This pre-conditioning process is a deviation from the standard which requires samples to be predried for $24 \mathrm{~h}$ at $60{ }^{\circ} \mathrm{C} \pm 3{ }^{\circ} \mathrm{C}$ $\left(140{ }^{\circ} \mathrm{F} \pm 5^{\circ} \mathrm{F}\right)$ prior to testing. Additionally specimens should placed in a conditioned environment maintained at $23{ }^{\circ} \mathrm{C} \pm 3{ }^{\circ} \mathrm{C}\left(73{ }^{\circ} \mathrm{F} \pm 5{ }^{\circ} \mathrm{F}\right)$ and a relative humidity of $50 \% \pm 5 \%$ from the time they are received until drying, sample preparation, and testing.

Test specimens measuring $3 \times 3$ in., $+0,-0.03$ in. $(76.2 \times 76.2 \mathrm{~mm},+0,-0.8 \mathrm{~mm})$ were covered across the back, and along the edges with a single sheet of aluminum foil with the dull side in contact with the specimen.

ASTM E 662 requires the test to be conducted for a period of $3 \mathrm{~min}$ after a minimum light transmittance value is reached, or for an exposure of $20 \mathrm{~min}$, whichever occurs first. SwRI conducted the tests for 20 minutes since the main directive for this test was particle size and distribution. 


\subsection{ACCEPTANCE Criteria}

No acceptance criteria for the particle size and distribution are published in ASTM E 662800 , nor were any provided by the Client.

\subsection{MATERial TeSTED}

Battelle Memorial Institute provided one 10-L jug of a material identified as ResorcinolFormaldehyde Polymer, which was received by SwRI on November 11, 2011. Table 1 contains a description of the material on the safety data sheet provided by the Client. A description of the materials tested as observed by SwRI personnel is provided in Table 2.

Table 1. Resorcinol-Formaldehyde Polymer Sample Description.

\begin{tabular}{|c|c||}
\hline Substance & Resorcinol-Formaldehyde Polymer \\
\hline \hline Trade Names/Synonyms & $\begin{array}{l}\text { 1,3-benzenediol-formaldehyde resin; formaldehyde- } \\
\text { resorcinal polymer; resorcin-formaldehyde polymer }\end{array}$ \\
\hline Chemical Family & Polymers \\
\hline Physical State & Solid Particles Dispersed in Water \\
\hline Color & Orange to Dark Red \\
\hline
\end{tabular}

\subsection{TEST RESUlts}

The tests were conducted on November 17-29, 2011, in general accordance with ASTM E 662. Test runs were carried out with a chamber wall temperature of $35^{\circ} \mathrm{C} \pm 2{ }^{\circ} \mathrm{C}\left(95^{\circ} \mathrm{F} \pm 4{ }^{\circ} \mathrm{F}\right)$. Test results for particle count and size are summarized in graphic form in Appendix A. 
APpendix A

Test Results

\section{(CONSISTING OF 3 PAGES)}




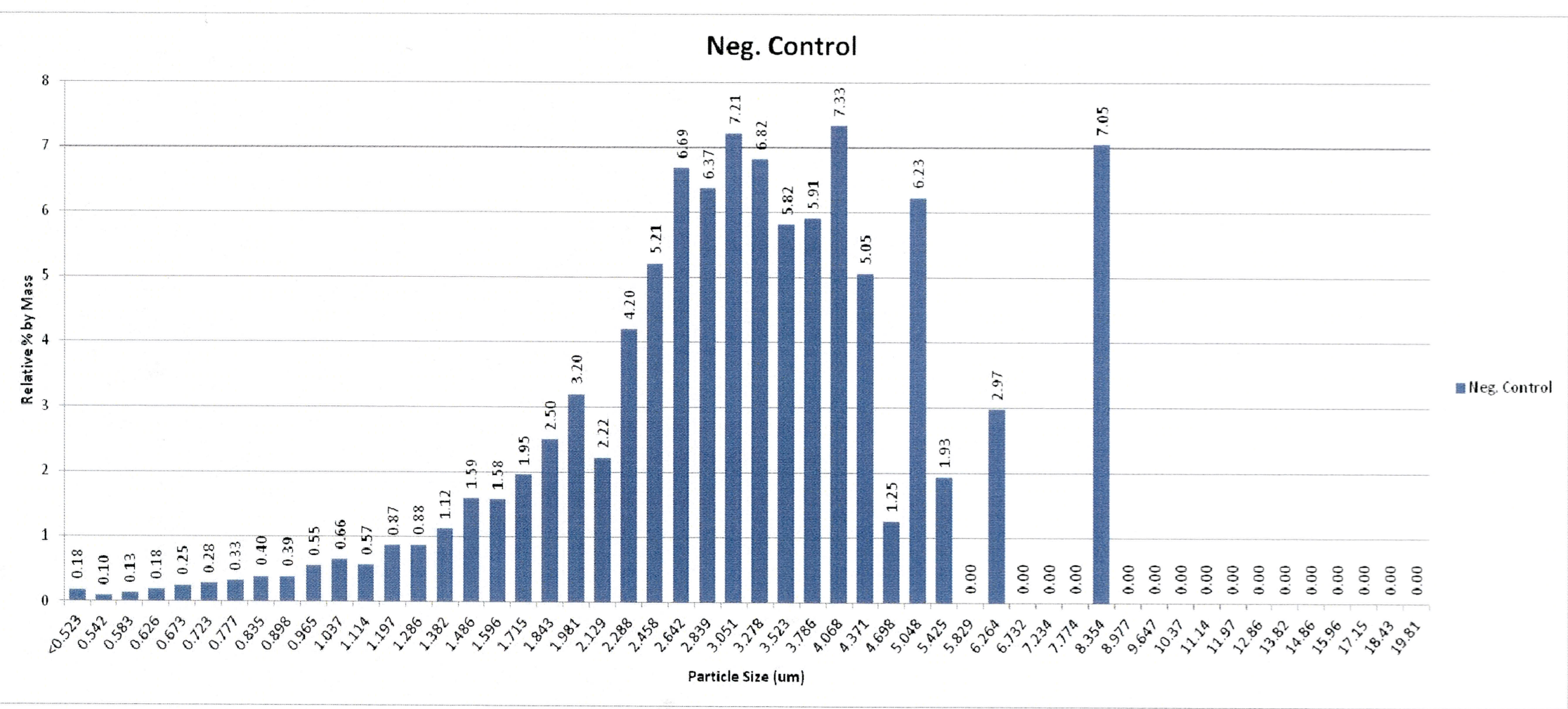




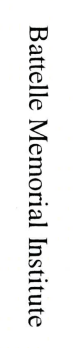

SRM

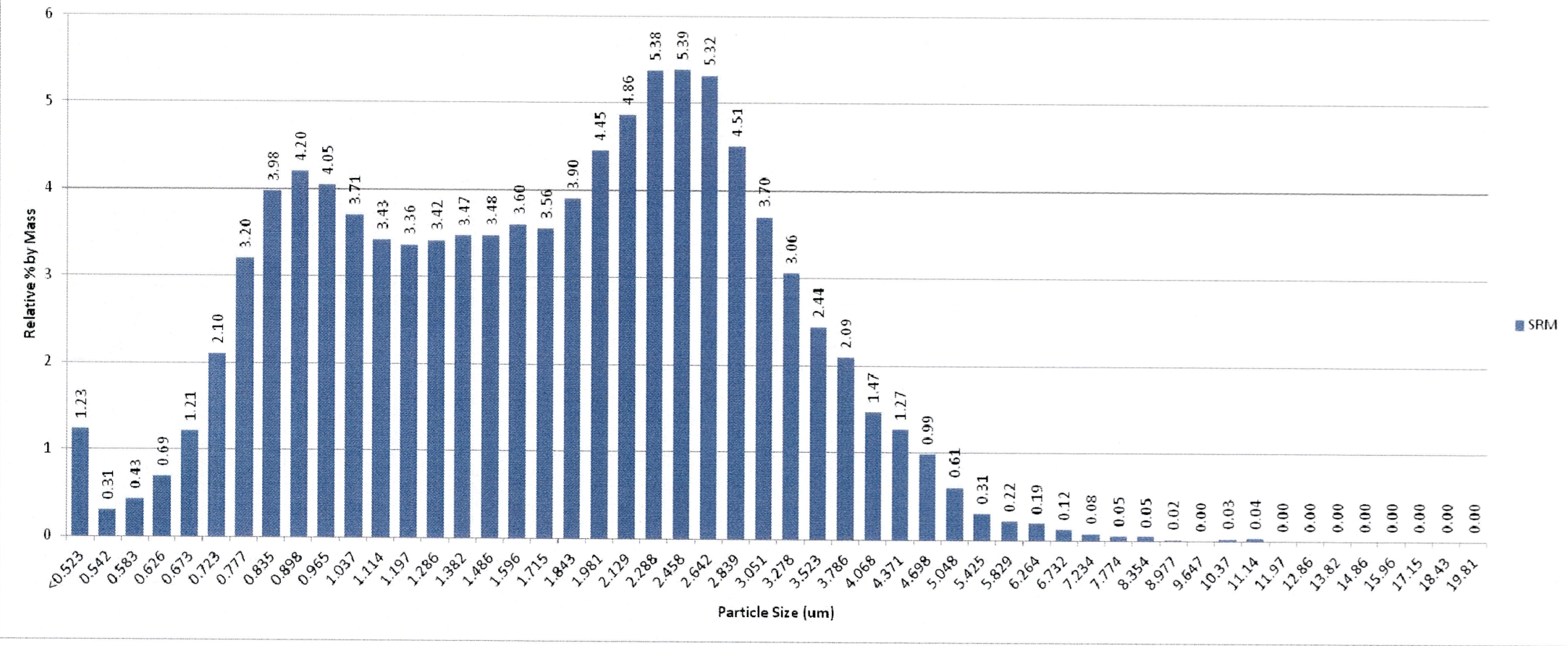




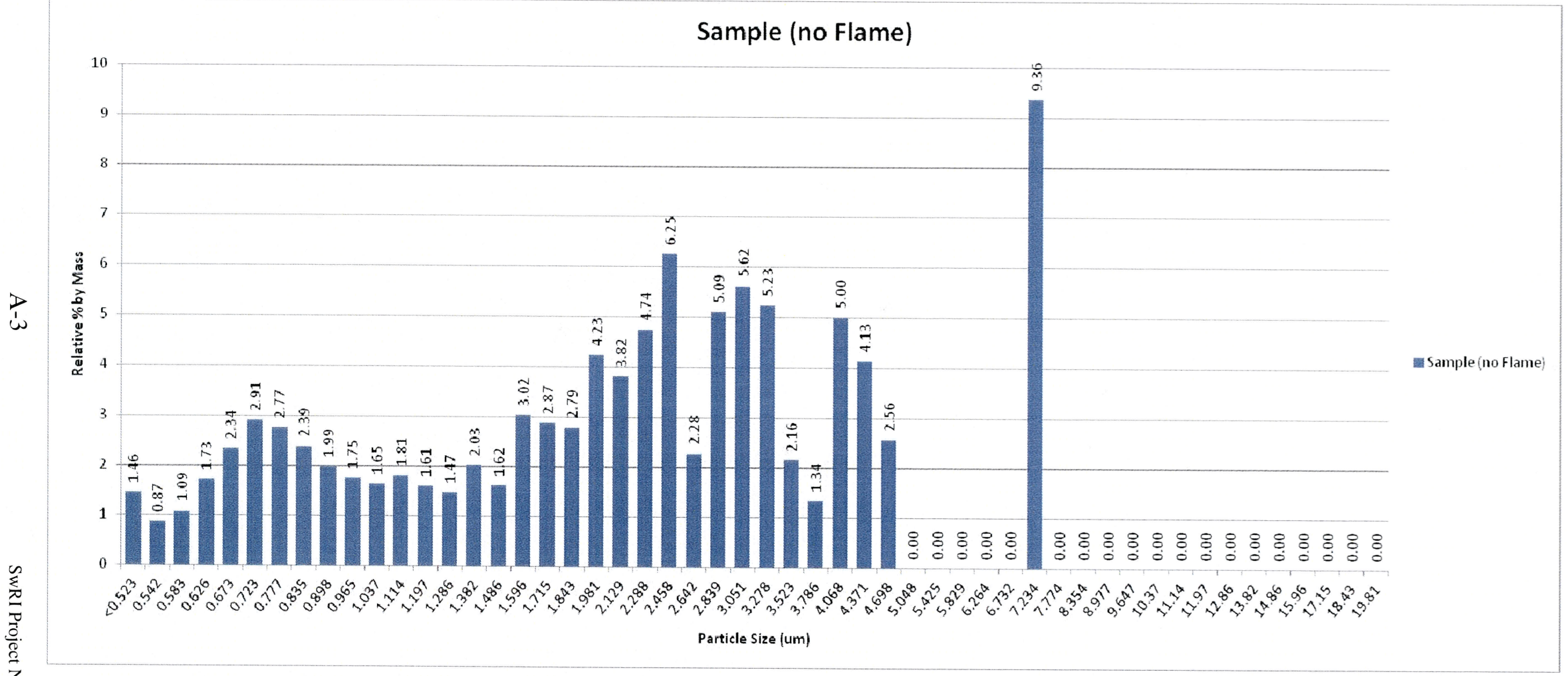


SOUTHWEST RESEARCH INSTITUTE CLIENT: Battelle Memorial Ins. PNNL TASK ORDER\#:

SRR\#:

111111-12

SDG\#:

46069

VTSR:

479235

PROJECT \#:

$11 / 11 / 2011$

13295.12.00X

\section{R13295.12.008f (ASTM E 662 and ASTM E 800 Testing)}




\section{S O U T H W E S T R E S E A R C H I N S T I T U T E ${ }^{\circledR}$}

6220 CULEBRA RD. 78238-5166 • P.O. DRAWER 28510 78228-0510 • SAN ANTONIO, TEXAS, USA • (210)684-5111 • WWW.SWRI.ORG CHEMISTRY AND CHEMICAL ENGINEERING DIVISION FIRE TECHNOLOGY DEPARTMENT WWW.FIRE.SWRI.ORG FAX (210) 522-3377

Optical SMoke Density Evaluation in General ACCORDANCE WITH ASTM E 662-09, STANDARD TEST METHOD FOR SPECIFIC OPTICAL DENSITY OF SMOKE GENERATED BY SOLID MATERIALS, AND SUPPLEMENTED WITH TOXICITY EVALUATION TESTED IN ACCORDANCE WITH ASTM E 800-07, STANDARD GUIDE FOR MEASUREMENT OF GASES PRESENT OR GENERATED DURING FIRES

MATERIAL ID: RESORCINOL-FORMALDEHYDE POLYMER

FINAL REPORT

Consisting of 15 Pages

SwRI ${ }^{\circledR}$ Project No. 01.13295.12.008f

Test Date: November 17-29, 2011

Report Date: December 15, 2011

Prepared for:

Battelle Memorial Institute

902 Battelle Blvd, K6-79

P.O. Box 999

Richland, WA 99352

Prepared by: Christina Gomez, Research Engineer

Submitted by:

Approved by:

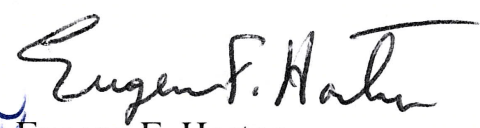

Eugene F. Horton

Senior Engineering Technologist

Material Flammability Section

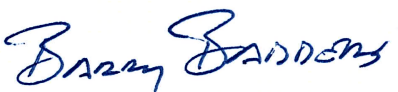

Matthew S. Blais, Ph.D.

Director

Fire Technology Department

This report is for the information of the Client. It may be used in its entirety for the purpose of securing product acceptance from duly constituted approval authorities. This report shall not be reproduced except in full, without the written approval of SwRI. Neither this report nor the name of the Institute shall be used in publicity or advertising. 


\section{ABSTRACT}

Battelle Memorial Institute located in Richland, Washington, submitted a material identified as Resorcinol-Formaldehyde Polymer for testing in general accordance with ASTM E 662 (2009), Standard Test Method for Specific Optical Density of Smoke Generated by Solid Materials, supplemented with toxicity analysis using ASTM E 800 (2007), Standard Guide for Measurement of Gases Present or Generated during Fires, as a guide. Four sets of tests were performed, one on a negative/blank specimen, one on a positive/standard specimen, one on the provided material (Resorcinol-Formaldehyde Polymer) and a duplicate on the provided material. The maximum concentrations detected using Fourier transform infrared (FTIR) spectroscopy are reported below along with summarized smoke density results. Maximum smoke density values are presented as an average of the corrected optical density values.

Resorcinol-Formaldehyde Polymer Performance SUMmary.

\begin{tabular}{|c|c|c|c|}
\hline \multicolumn{4}{|c|}{ Specific Optical Density $\left(D_{S}\right)$ Results } \\
\hline $25 \mathrm{~kW} / \mathrm{m}^{2}$ & $\begin{array}{c}\text { Average } D_{S} \text { at } \\
1.5 \mathrm{~min}\end{array}$ & $\underset{\text { min }}{\text { Average } D_{s} \text { at } 4}$ & $\begin{array}{l}\text { Average Max } \\
\text { Corrected } D_{S}\end{array}$ \\
\hline Blank - Flaming & 0.38 & 0.43 & 0.50 \\
\hline Blank - Nonflaming & 0.24 & 0.22 & 0.00 \\
\hline Standard - Flaming & 105 & 90 & 92 \\
\hline Standard - Nonflaming & 18 & 148 & 150 \\
\hline Material - Flaming & 0.26 & 0.28 & 0.56 \\
\hline Material - Nonflaming & 0.21 & 0.22 & 0.30 \\
\hline Material Duplicate - Nonflaming & 0.36 & 0.44 & 0.41 \\
\hline Material Duplicate - Flaming & 0.15 & 0.12 & 0.21 \\
\hline
\end{tabular}

\begin{tabular}{||l|c|c|c|c|c|c|c|c||}
\hline \multicolumn{10}{|c||}{ Maximum Concentrations (ppm) } \\
\hline \hline \multicolumn{1}{|c|}{ Test } & CO & CO $_{2}$ & HBr & HCI & HCN & HF & NO $_{\mathbf{x}}$ & SO $_{2}$ \\
\hline Blank - Nonflaming & $-* *$ & $116 \pm 21$ & - & - & - & - & - & - \\
\hline Blank - Flaming & - & $1113 \pm 38$ & - & - & $10 \pm 2$ & - & - & - \\
\hline Standard - Nonflaming & $332 \pm 2$ & $820 \pm 37$ & - & - & - & - & - & $3 \pm 1$ \\
\hline Standard - Flaming & $20 \pm 1$ & $501 \pm 7$ & - & - & - & - & - & - \\
\hline Material - Nonflaming & $803 \pm 6$ & $834 \pm 41$ & - & - & - & - & - & $3 \pm 1$ \\
\hline Material - Flaming & $1681 \pm 18$ & $1628 \pm 63$ & - & - & - & - & - & $7 \pm 2$ \\
\hline Duplicate - Nonflaming & $88 \pm 1$ & $3421 \pm 123$ & - & - & - & - & - & $2.3 \pm 1.5$ \\
\hline Duplicate - Flaming & $762 \pm 55$ & $1057 \pm 43$ & - & - & - & - & - & $7 \pm 3$ \\
\hline
\end{tabular}

* \pm Represents $90 \%$ confidence interval.

** Represents gas not detected. 


\subsection{INTRODUCTION}

This report presents the results of a smoke density and toxicity evaluation conducted at Southwest Research Institute's (SwRI) Fire Technology Department, located in San Antonio, Texas. The smoke density evaluation was conducted in accordance with ASTM E 662 (2006), Standard Test Method for Specific Optical Density of Smoke Generated by Solid Materials. The toxicity evaluation was performed using Fourier transform infrared (FTIR) spectroscopy using ASTM E 800 (2007), Standard Guide for Measurement of Gases Present or Generated during Fires. The sample for FTIR analysis is drawn from smoke runs of the E 662 test. The deviations from the standard include the pre-conditioning procedure, the heater and orientation, and the additional tests.

Testing was performed on the test samples in accordance with the quality assurance requirements of the DOE/RL-96-68, Hanford Analytical Services Quality Assurance Requirements Documents, Volumes 1 and 4 (HASQARDS), latest revision. In accordance with the HASQARDs, a positive, a negative and a duplicate test were run, in addition to the one standard test.

The negative tests were performed on calcium silicate, which is a non-combustible material. This material is used as often as a substrate or backer board in standard fire testing. It does not react to flame or heat except to lose moisture, and therefore for smoke and toxicity, it was used as a negative material test. The positive tests were performed in the nonflaming mode on an $\alpha$-cellulose material from Fire Testing Technologies, and in the flaming mode on Schneller Standard Core Panel.

A radiant heat furnace was used to provide a constant irradiance of $25 \mathrm{~kW} / \mathrm{m}^{2}$ in two exposures: flaming and nonflaming. The furnace used was not the same as prescribed in the ASTM E 662 standard. Because the material could not sit in the sample holder in a vertical orientation, the ISO 5659 furnace, a radiator cone, was used. The ISO 5659 is a similar smoke generation test which is typically run in the horizontal orientation. A pilot flame was used during flaming exposure and was centered in front of and parallel to the specimen holder. The pilot flame was also different from that described in the ASTM E662, which is a six-flamelet pilot burner. Instead the ISO 5659, single pilot flame burner was used.

Smoke density measurement is made based on the attenuation of a vertically oriented light beam through smoke accumulating within the chamber. Results are expressed in terms of the dimensionless specific optical density, $D_{s}$. A clear beam value is recorded upon evacuation of smoke from the box to determine a correction factor. The maximum corrected smoke density value from each of the runs at a single exposure condition are averaged and reported. Per the standard, smoke density values are rounded to two significant figures.

The samples provided consisted of a micro bead material dispersed in water. The material was tested in worst case scenario, which is with the water removed. This process was achieved by first filtering the material, and then drying it in an oven. The sample was predried for a minimum of $10 \mathrm{~h}$ at 60 
$60^{\circ} \mathrm{C} \pm 3{ }^{\circ} \mathrm{C}\left(140^{\circ} \mathrm{F} \pm 5^{\circ} \mathrm{F}\right)$ prior to testing. After drying, the sample consisted of only the microbead material; the beads became statically charged in the absence of the water medium and therefore, they were placed in a closed container after drying, in an effort not to lose any beads. This pre-conditioning process is a deviation from the standard which requires samples to be predried for $24 \mathrm{~h}$ at $60{ }^{\circ} \mathrm{C} \pm 3{ }^{\circ} \mathrm{C}$ $\left(140^{\circ} \mathrm{F} \pm 5^{\circ} \mathrm{F}\right)$ prior to testing. Additionally specimens should placed in a conditioned environment maintained at $23{ }^{\circ} \mathrm{C} \pm 3{ }^{\circ} \mathrm{C}\left(73{ }^{\circ} \mathrm{F} \pm 5{ }^{\circ} \mathrm{F}\right)$ and a relative humidity of $50 \% \pm 5 \%$ from the time they are received until drying, sample preparation, and testing.

Test specimens measuring $3 \times 3$ in., $+0,-0.03$ in. $(76.2 \times 76.2 \mathrm{~mm},+0,-0.8 \mathrm{~mm})$ were covered across the back, and along the edges with a single sheet of aluminum foil with the dull side in contact with the specimen.

ASTM E 662 requires the test to be conducted for a period of 3 min after a minimum light transmittance value is reached, or for an exposure of $20 \mathrm{~min}$, whichever occurs first. SwRI conducts tests for 10 min unless a minimum light transmittance value has not yet occurred, then the test is continued for an additional $10 \mathrm{~min}$. Notes are made relevant to any burning characteristics such as delamination, intumescence, shrinkage, and ignition.

Gas analysis is performed during the third run in each exposure mode and analyzed using an FTIR spectrometer. The sample is drawn through a preheated line to prevent condensation and adsorption, and filtered into a preheated gas cell. Analysis is conducted for carbon monoxide (CO), carbon dioxide $\left(\mathrm{CO}_{2}\right)$, hydrogen chloride $(\mathrm{HCl})$, hydrogen cyanide $(\mathrm{HCN})$, hydrogen fluoride $(\mathrm{HF})$, hydrogen bromide $(\mathrm{HBr})$, sulfur dioxide $\left(\mathrm{SO}_{2}\right)$, and oxides of nitrogen $\left(\mathrm{NO}_{\mathrm{X}}\right)$.

This test method is intended to measure and describe the properties of products in response to heat and flame under controlled laboratory conditions. The results should not be used alone to describe or appraise the fire hazard or the fire risk of materials, products, or assemblies under actual fire conditions. However, results of this test may be used as elements of a complete fire hazard assessment or a fire risk assessment, which takes into account all the factors that are pertinent to an assessment of the fire hazard or fire risk of a particular end use. The results apply specifically to the specimens tested, in the manner tested, and not to similar materials, nor to the performance when used in combination with other materials.

\subsection{ACCEPTANCE CRITERIA}

No acceptance criteria for smoke density or toxicity are published in ASTM E 662 or ASTM E 800, nor were any provided by the Client. 


\section{0}

MAterial Tested

Battelle Memorial Institute, located in Richland, Washington, provided one 10-L jug of a material identified as Resorcinol-Formaldehyde Polymer, which was received by SwRI on November 11, 2011. Table 1 contains a description of the material on the safety data sheet provided by the Client. A description of the materials tested as observed by SwRI personnel is provided in Table 2.

Table 1. Resorcinol-Formaldehyde Polymer Sample Description.

\begin{tabular}{|c|c|}
\hline Substance & Rescorcinol-formaldehyde polymer \\
\hline \hline Trade Names/Synonyms & $\begin{array}{c}\text { 1,3-benzenediol-formaldehyde resin; } \\
\text { formaldehyde-resorcinal polymer; } \\
\text { resorcin-formaldehyde polymer }\end{array}$ \\
\hline Chemical Family & Polymers \\
\hline Physical State & Solid particles dispersed in water \\
\hline Color & Orange to dark red \\
\hline
\end{tabular}

Table 2. Test Sample Descriptions.

\begin{tabular}{|c|c|c|c||}
\hline Material ID & $\begin{array}{c}\text { Nominal Tested } \\
\text { Thickness* }\end{array}$ & $\begin{array}{c}\text { Nominal Tested } \\
\text { Mass* }\end{array}$ & Color* \\
\hline $\begin{array}{c}\text { Resorcinol-Formaldehyde } \\
\text { Polymer (beads) }\end{array}$ & $25 \mathrm{~mm}$ & $82 \mathrm{~g}$ & $\begin{array}{c}\text { Rust } \\
\text { Red }\end{array}$ \\
\hline Calcium silicate (blank) & $25 \mathrm{~mm}$ & $92 \mathrm{~g}$ & White \\
\hline $\begin{array}{c}\alpha \text {-cellulose material } \\
\text { (Standard nonflaming) }\end{array}$ & $1.5 \mathrm{~mm}$ & $3 \mathrm{~g}$ & White \\
\hline $\begin{array}{c}\text { Schneller Core Panel } \\
\text { (Standard flaming) }\end{array}$ & $3.8 \mathrm{~mm}$ & $8 \mathrm{~g}$ & Amber \\
\hline
\end{tabular}

* Measured by SwRI personnel.

\subsection{Test Results}

The tests were conducted on November 17-29, 2011, in accordance with ASTM E 662 and ASTM E 800. Test runs were carried out with a chamber wall temperature of $35{ }^{\circ} \mathrm{C} \pm 2{ }^{\circ} \mathrm{C}\left(95{ }^{\circ} \mathrm{F} \pm\right.$ $4{ }^{\circ} \mathrm{F}$ ). Test results for smoke density are summarized in Tables $2-7$ with toxicity results summarized in Table 8. Figures $1-8$, the standard ASTM E 662 test data sheets, provide more detailed information including mass loss, time to maximum smoke density, and visual observations for each test run. 
Table 2. Flaming Exposure Specific Optical Density Results for Blank and Standard.

\begin{tabular}{||c|c|c|c|c|c|c||}
\hline Material & Test ID & $\begin{array}{c}\mathbf{D}_{\mathrm{S}} \text { at 1.5 } \\
\mathbf{m i n}\end{array}$ & $\begin{array}{c}\mathbf{D}_{\mathrm{S}} \text { at4.0 } \\
\mathbf{m i n}\end{array}$ & $\begin{array}{c}\text { Maximum } \\
\mathbf{D}_{\mathrm{S}}\end{array}$ & $\begin{array}{c}\text { Maximum } \mathbf{D}_{\mathrm{S}} \\
(\text { corrected) }\end{array}$ & $\begin{array}{c}\text { Time to Max } \\
\mathbf{D}_{\mathrm{S}} \text { (s) }\end{array}$ \\
\hline \hline Blank & $11-321 \mathrm{P} 3$ & 0.38 & 0.43 & 0.50 & 0.50 & 239 \\
\hline Standard & $11-332 \mathrm{P} 1$ & 110 & 90 & 110 & 90 & 86 \\
\hline \hline
\end{tabular}

Table 3. Nonflaming Exposure Specific Optical Density Results for Blank and Standard.

\begin{tabular}{|c|c|c|c|c|c|c||}
\hline \hline Material & Test ID & $\begin{array}{c}\mathbf{D}_{\text {S }} \text { at } \mathbf{1 . 5} \\
\mathbf{m i n}\end{array}$ & $\begin{array}{c}\mathbf{D}_{\mathrm{S}} \text { at4.0 } \\
\mathbf{m i n}\end{array}$ & $\begin{array}{c}\text { Maximum } \\
\mathbf{D}_{\mathrm{S}}\end{array}$ & $\begin{array}{c}\text { Maximum } \mathbf{D}_{\mathrm{S}} \\
(\text { corrected) }\end{array}$ & $\begin{array}{c}\text { Time to Max } \\
\mathbf{D}_{\mathrm{S}}(\mathbf{s})\end{array}$ \\
\hline \hline Blank & $11-321 \mathrm{P} 2$ & 0.24 & 0.22 & 0.47 & 0.00 & 1082 \\
\hline Standard & $11-321 \mathrm{P} 1$ & 18 & 150 & 180 & 180 & 150 \\
\hline \hline
\end{tabular}

Table 4. Flaming Exposure Specific Optical Density Results for Resorcinol-Formaldehyde Polymer.

\begin{tabular}{|c|c|c|c|c|c||}
\hline \hline Test ID & D $_{\mathbf{S}}$ at 1.5 min & $\mathbf{D}_{\mathbf{S}}$ at4.0 min & Maximum $\mathbf{D}_{\mathbf{S}}$ & $\begin{array}{c}\text { Maximum } \mathbf{D}_{\mathbf{S}} \\
(\text { corrected })\end{array}$ & $\begin{array}{c}\text { Time to Maximum } \\
\mathbf{D}_{\mathbf{S}}(\mathbf{s})\end{array}$ \\
\hline \hline 11 -332P2 & 0.02 & 0.00 & 0.61 & 0.61 & 968 \\
\hline 1 1-332P3 & 0.33 & 0.39 & 0.47 & 0.47 & 278 \\
\hline 11 -332P4 & 0.42 & 0.44 & 0.70 & 0.59 & 686 \\
\hline Average: & 0.26 & 0.28 & 0.60 & 0.56 & 644 \\
\hline Range: & $0.02-0.42$ & $0.00-0.44$ & $0.47-0.70$ & $0.47-0.61$ & \\
\hline
\end{tabular}

Table 5. Nonflaming Exposure Specific Optical Density Results for Resorcinol-Formaldehyde Polymer.

\begin{tabular}{||c|c|c|c|c|c||}
\hline \hline Test ID & D $_{\mathbf{S}}$ at 1.5 min & $\mathbf{D}_{\mathbf{S}}$ at 4.0 min & Maximum $\mathbf{D}_{\mathbf{S}}$ & $\begin{array}{c}\text { Maximum } \\
(\text { corrected })\end{array}$ & $\begin{array}{c}\text { Time to Maximum } \\
\mathbf{D}_{\mathbf{S}}(\mathbf{s})\end{array}$ \\
\hline \hline $11-322 \mathrm{P} 1$ & 0.20 & 0.28 & 0.40 & 0.40 & 475 \\
\hline $11-322 \mathrm{P} 2$ & 0.23 & 0.18 & 0.36 & 0.36 & 416 \\
\hline $11-322 \mathrm{P} 3$ & 0.19 & 0.22 & 0.57 & 0.13 & 1165 \\
\hline Average: & 0.21 & 0.22 & 0.44 & 0.30 & 685 \\
\hline Range: & $0.19-0.23$ & $0.18-0.28$ & $0.36-0.57$ & $0.13-0.40$ & \\
\hline
\end{tabular}

Table 6. Duplicate Flaming Exposure Specific Optical Density Results for Resorcinol-Formaldehyde Polymer.

\begin{tabular}{|c|c|c|c|c|c||}
\hline Test ID & $\mathbf{D}_{\mathbf{S}}$ at 1.5 min & $\mathbf{D}_{\mathbf{S}}$ at4.0 min & Maximum $\mathbf{D}_{\mathbf{S}}$ & $\begin{array}{c}\text { Maximum } \mathbf{D}_{\mathbf{S}} \\
(\mathbf{c o r r e c t e d})\end{array}$ & $\begin{array}{c}\text { Time to Maximum } \\
\mathbf{D}_{\mathbf{S}}(\mathbf{s})\end{array}$ \\
\hline \hline $11-333 \mathrm{P} 1$ & 0.05 & 0.04 & 0.15 & 0.15 & 747 \\
\hline $11-333 \mathrm{P} 2$ & 0.61 & 0.74 & 1.14 & 0.45 & 836 \\
\hline $11-333 \mathrm{P} 3$ & 0.41 & 0.54 & 0.83 & 0.62 & 1198 \\
\hline Average: & 0.36 & 0.44 & 0.70 & 0.41 & 927 \\
\hline Range: & $0.05-0.61$ & $0.04-0.74$ & $0.15-1.14$ & $0.15-0.62$ & \\
\hline
\end{tabular}


Table 7. Duplicate Nonflaming Exposure Specific Optical Density Results for Resorcinol-Formaldehyde Polymer.

\begin{tabular}{||c|c|c|c|c|c||}
\hline \hline Test ID & $\mathbf{D}_{\mathbf{S}}$ at 1.5 $\mathbf{m i n}$ & $\mathbf{D}_{\mathbf{S}}$ at 4.0 $\mathbf{m i n}$ & Maximum $\mathbf{D}_{\mathbf{S}}$ & $\begin{array}{c}\text { Maximum } \mathbf{D}_{\mathbf{S}} \\
(\text { corrected) }\end{array}$ & $\begin{array}{c}\text { Time to Maximum } \\
\mathbf{D}_{\mathbf{S}}(\mathbf{s})\end{array}$ \\
\hline \hline $11-322 \mathrm{P} 4$ & 0.08 & 0.03 & 0.24 & 0.24 & 587 \\
\hline $11-322 \mathrm{P} 5$ & 0.18 & 0.10 & 0.28 & 0.28 & 37 \\
\hline $11-323 \mathrm{P} 1$ & 0.18 & 0.23 & 0.27 & 0.11 & 239 \\
\hline Average: & 0.15 & 0.12 & 0.26 & 0.21 & 288 \\
\hline Range: & $0.08-0.18$ & $0.03-0.23$ & $0.24-0.28$ & $0.11-0.28$ & \\
\hline
\end{tabular}

Table 8. Maximum Concentrations Detected in Parts Per Million (ppm).

\begin{tabular}{|c|c|c|c|c|c|c|c|c|c|}
\hline Material & $\begin{array}{c}\text { Exposure } \\
\text { Mode }\end{array}$ & $\mathrm{CO}$ & $\mathrm{CO}_{2}$ & $\mathrm{HBr}$ & $\mathrm{HCl}$ & $\mathrm{HCN}$ & HF & $\mathbf{N O}_{\mathrm{X}}$ & $\mathrm{SO}_{2}$ \\
\hline \multirow{2}{*}{ Blank } & Nonflaming & —** & $116 \pm 21^{*}$ & - & - & - & - & 一 & - \\
\hline & Flaming & - & $1113 \pm 38$ & - & - & $10 \pm 2$ & - & - & - \\
\hline \multirow{2}{*}{ Standard } & Nonflaming & $332 \pm 2$ & $820 \pm 37$ & - & - & - & - & - & $3 \pm 1$ \\
\hline & Flaming & $20 \pm 1$ & $501 \pm 7$ & - & - & - & - & - & - \\
\hline \multirow{2}{*}{$\begin{array}{l}\text { Resorcinol- } \\
\text { Formaldehyde } \\
\text { Polymer }\end{array}$} & Nonflaming & $803 \pm 6$ & $834 \pm 41$ & 一 & - & - & - & - & $3 \pm 1$ \\
\hline & Flaming & $1681 \pm 18$ & $1628 \pm 63$ & - & - & - & - & - & $7 \pm 2$ \\
\hline \multirow{2}{*}{$\begin{array}{c}\text { Resorcinol- } \\
\text { Formaldehyde } \\
\text { Polymer }\end{array}$} & Nonflaming & $88 \pm 1$ & $3421 \pm 123$ & - & - & - & - & - & $2.3 \pm 1.5$ \\
\hline & Flaming & $762 \pm 55$ & $1057 \pm 43$ & - & - & - & - & - & $7 \pm 3$ \\
\hline
\end{tabular}

$* \pm$ Represents the $90 \%$ confidence level in the concentration measurement.

**Represents gas not detected 
S OUTHWES T RES EAR CH INS TITUTE

\section{ASTM E 662 SMOKE DENSITY TEST REPORT}

$\begin{array}{ll}\text { Client: } & \text { Battelle Memorial Institute } \\ \text { Operator: } & \text { P. Lopez } \\ \text { Test Date(s): } & \text { November 17, } 2011 \\ \text { Project No. } & 01.13295 .12 .008 f \\ \text { Material ID*: } & \text { Blank } \\ \text { Description*: } & \text { Non-combustible calcium silicate board } \\ & \\ & \\ & \end{array}$

Heat Flux:
Exposure Mode:
Orientation:
Color:
Thickness:
Receipt Date:
Date Prepared by SwRI:
Oven Cure:
Note:

$25 \mathrm{~kW} / \mathrm{m}^{2}$

Piloted (Flaming)

Horizontal

White

$25 \mathrm{~mm}$

Not Applicable

Cut to size on test date

None

\section{RESULTS}

\begin{tabular}{|c|c|c|c|c|c|c|c|c|c|}
\hline Test ID & $\begin{array}{c}\text { Initial } \\
\text { Mass } \\
(\mathrm{g})\end{array}$ & $\begin{array}{c}\text { Final } \\
\text { Mass } \\
(\mathrm{g}) \\
\end{array}$ & $\begin{array}{c}\text { Mass } \\
\text { Loss } \\
(\mathrm{g}) \\
\end{array}$ & $\begin{array}{c}1.5 \mathrm{~min} \\
\mathrm{D}_{\mathrm{s}}\end{array}$ & $\begin{array}{c}4.0 \mathrm{~min} \\
\mathrm{D}_{\mathrm{s}}\end{array}$ & $\begin{array}{c}\text { Maximum } \\
D_{\mathrm{s}}\end{array}$ & $\begin{array}{l}\text { Time to } \\
\text { Max. } D_{s} \\
\text { (sec) }\end{array}$ & $\begin{array}{c}\text { Correction } \\
\text { Factor }\end{array}$ & $\begin{array}{l}\text { Corrected Max. } \\
\qquad D_{s}\end{array}$ \\
\hline 11-321P3 & 95.76 & 93.96 & 1.80 & 0.38 & 0.43 & 0.50 & 239 & 0.00 & 0.50 \\
\hline Average & 95.76 & 93.96 & 1.80 & 0.38 & 0.43 & 0.50 & 239 & 0.00 & 0.50 \\
\hline
\end{tabular}

\section{OBSERVATIONS}

\begin{tabular}{|c|c|c|c|c|c|c|c|c|}
\hline Test ID & $\begin{array}{l}\text { Observed } \\
\text { Smoke } \\
(\mathrm{sec})\end{array}$ & $\begin{array}{l}\text { Surface Char } \\
\text { (sec) }\end{array}$ & $\begin{array}{c}\text { Observed } \\
\text { Blistering } \\
(\mathrm{sec})\end{array}$ & $\begin{array}{l}\text { Time to } \\
\text { Ignition } \\
\text { (sec) }\end{array}$ & $\begin{array}{c}\text { Flames to } \\
\text { Top } \\
(\mathrm{sec})\end{array}$ & $\begin{array}{c}\text { Initial Flame } \\
\text { Out } \\
\text { (sec) }\end{array}$ & $\begin{array}{l}\text { Second } \\
\text { Ignition } \\
\text { (sec) }\end{array}$ & $\begin{array}{c}\text { Final Flame } \\
\text { Out } \\
\text { (sec) }\end{array}$ \\
\hline $11-321 \mathrm{P3}$ & - & - & - & - & - & - & - & - \\
\hline Average & - & - & - & - & - & - & - & - \\
\hline
\end{tabular}

\section{OPTICAL DENSITY CHART}

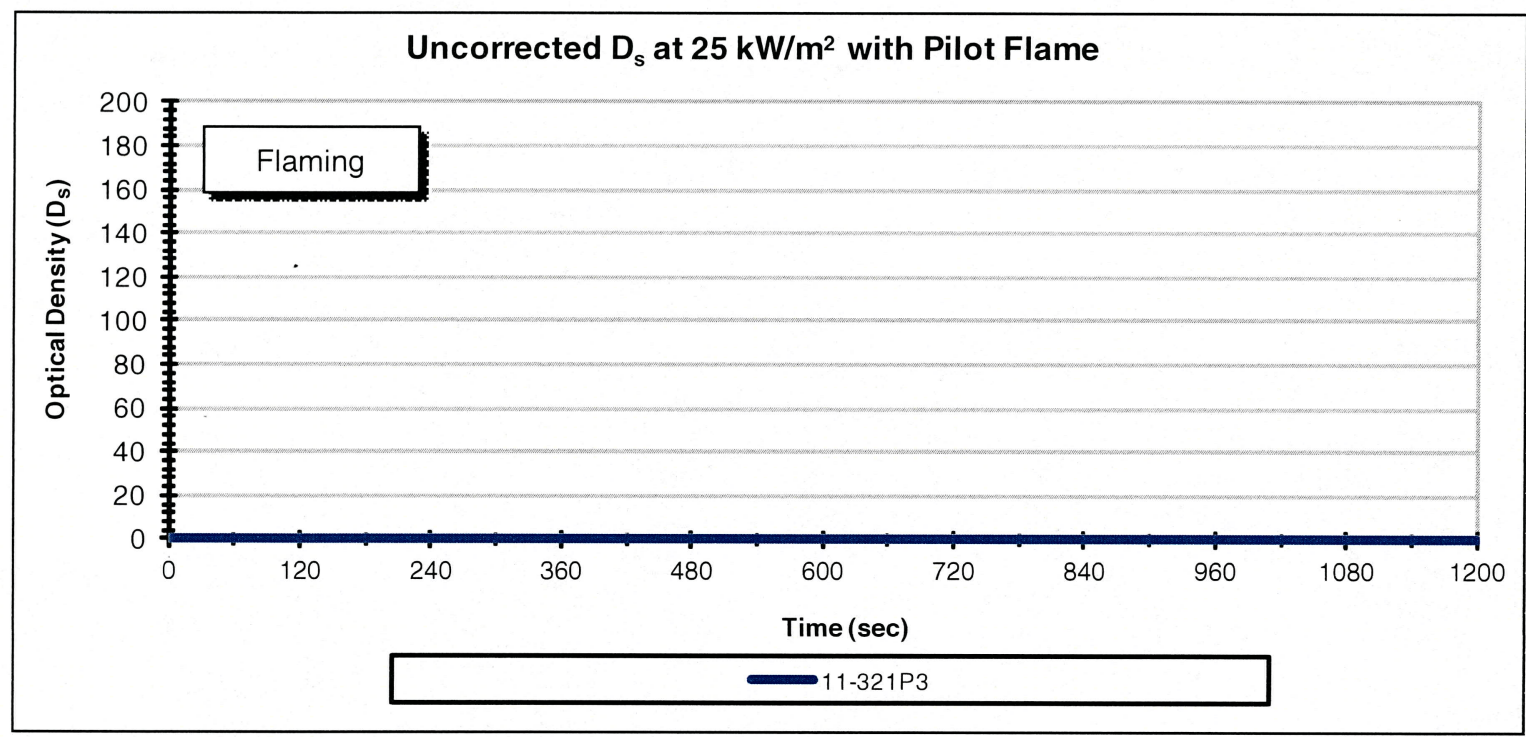

Figure 1. Smoke Density Results during Flaming Exposure - Blank. 
SOUTHWES T RES EARCH INS TITUTE

\section{ASTM E 662 SMOKE DENSITY TEST REPORT}

$\begin{array}{ll}\text { Client: } & \text { Battelle Memorial Institute } \\ \text { Operator: } & \text { P. Lopez } \\ \text { Test Date(s): } & \text { November } 18 \text { and 19, } 2011 \\ \text { Project No. } & 01.13295 .12 .008 f \\ \text { Material ID*: } & \text { Blank } \\ \text { Description*: } & \text { Non-combustible calcium silicate board } \\ & \\ & \\ & \end{array}$

Heat Flux:
Exposure Mode:
Orientation:
Color:
Thickness:
Receipt Date:
Date Prepared by SwRI:
Oven Cure Date:
Note:

$25 \mathrm{~kW} / \mathrm{m}^{2}$

No pilot (nonflaming)

Horizontal

White

$25 \mathrm{~mm}$

Not Applicable

Cut to size on test date

None

RESULTS

\begin{tabular}{|c|c|c|c|c|c|c|c|c|c|}
\hline Test ID & $\begin{array}{c}\text { Initial } \\
\text { Mass } \\
(\mathrm{g})\end{array}$ & $\begin{array}{c}\text { Final } \\
\text { Mass } \\
(\mathrm{g})\end{array}$ & $\begin{array}{c}\text { Mass } \\
\text { Loss } \\
(\mathrm{g}) \\
\end{array}$ & $\begin{array}{c}1.5 \mathrm{~min} \\
\mathrm{D}_{\mathrm{s}}\end{array}$ & $\begin{array}{c}4.0 \mathrm{~min} \\
\mathrm{D}_{\mathrm{s}}\end{array}$ & $\begin{array}{c}\text { Maximum } \\
D_{s}\end{array}$ & $\begin{array}{l}\text { Time to } \\
\text { Max. } D_{s} \\
(\mathrm{sec})\end{array}$ & $\begin{array}{c}\text { Correction } \\
\text { Factor }\end{array}$ & $\begin{array}{l}\text { Corrected Max. } \\
\qquad D_{s}\end{array}$ \\
\hline 11-321P2 & 90.62 & 88.62 & 2.00 & 0.24 & 0.22 & 0.47 & 1082 & 0.47 & 0.00 \\
\hline Average & 90.62 & 88.62 & 2.00 & 0.24 & 0.22 & 0.47 & 1082 & 0.47 & 0.00 \\
\hline
\end{tabular}

\section{OBSERVATIONS}

\begin{tabular}{|c|c|c|c|c|c|c|c|c|}
\hline Test ID & $\begin{array}{l}\text { Observed } \\
\text { Smoke } \\
(\mathrm{sec})\end{array}$ & $\begin{array}{c}\text { Surface Char } \\
\text { (sec) }\end{array}$ & $\begin{array}{c}\text { Observed } \\
\text { Blistering } \\
\text { (sec) }\end{array}$ & $\begin{array}{l}\text { Time to } \\
\text { Ignition } \\
\text { (sec) }\end{array}$ & $\begin{array}{c}\text { Flames to } \\
\text { Top } \\
(\mathrm{sec})\end{array}$ & $\begin{array}{c}\text { Initial Flame } \\
\text { Out } \\
\text { (sec) }\end{array}$ & $\begin{array}{l}\text { Second } \\
\text { Ignition } \\
(\mathrm{sec})\end{array}$ & $\begin{array}{c}\text { Final Flame } \\
\text { Out } \\
(\mathrm{sec})\end{array}$ \\
\hline 11-321P2 & - & - & - & - & - & - & - & - \\
\hline Average & - & - & - & - & - & - & - & - \\
\hline
\end{tabular}

\section{OPTICAL DENSITY CHART}

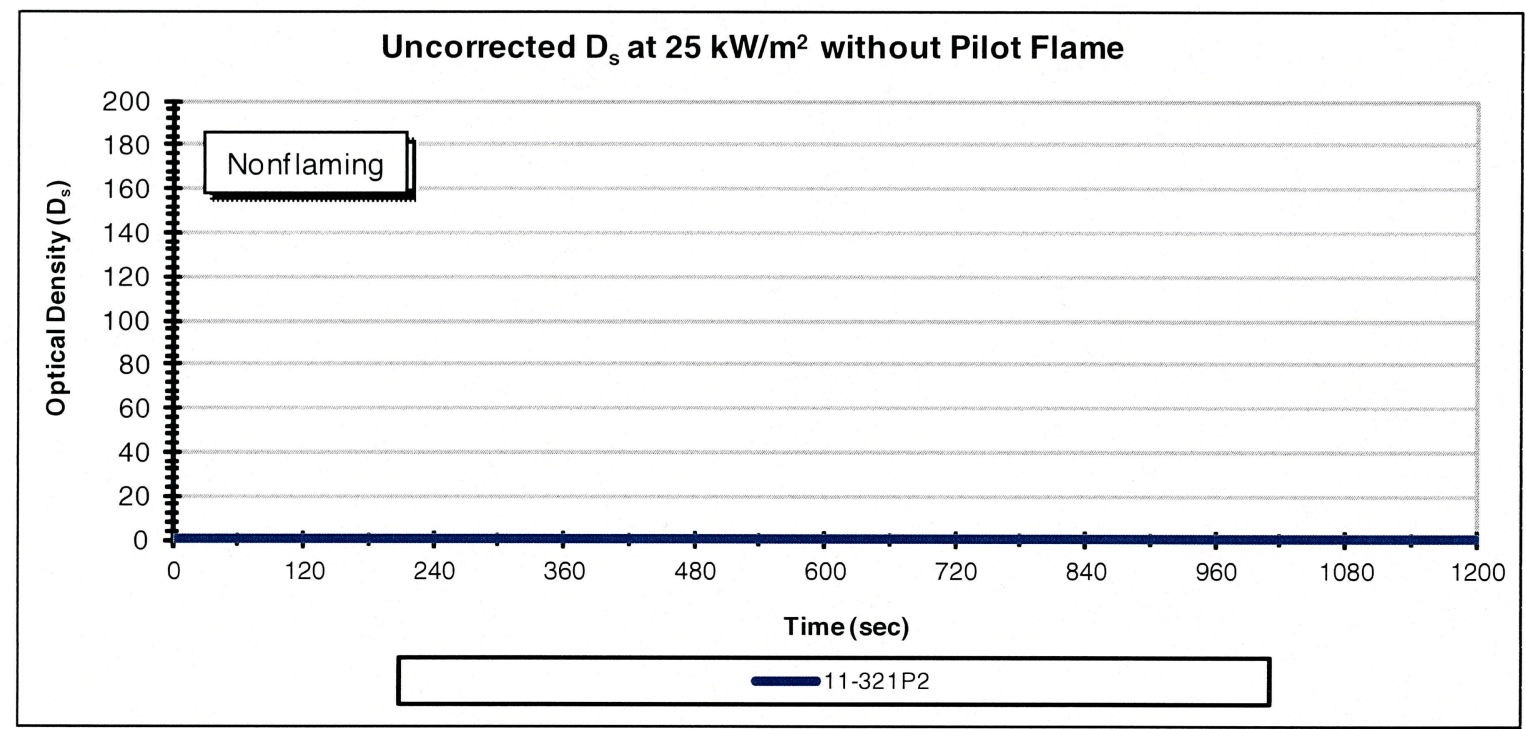

Figure 2. Smoke Density Results during Nonflaming Exposure - Blank. 
SOUTHWES T RES EAR CH INS TITUTE

\section{ASTM E 662 SMOKE DENSITY TEST REPORT}

\begin{tabular}{|c|c|}
\hline Client: & Battelle Memorial Institute \\
\hline Operator: & P. Lopez \\
\hline Test Date(s): & November 28, 2011 \\
\hline Project No. & $01.13295 .12 .008 f$ \\
\hline Material ID*: & Standard Reference Material \\
\hline Description*: & $\begin{array}{l}\text { Reference material from Schneller - Schneller } \\
\text { Standard Core Panel with Ha211 applied }\end{array}$ \\
\hline
\end{tabular}

Heat Flux:
Exposure Mode:
Orientation:
Color:
Thickness:
Receipt Date:
Date Prepared by SwRI:
Oven Cure:
Note:

$25 \mathrm{~kW} / \mathrm{m}^{2}$

Piloted (Flaming)

Horizontal

Amber

$3.82 \mathrm{~mm}$

November 18, 2011

Cut to size on test date

None

\section{RESULTS}

\begin{tabular}{|c|c|c|c|c|c|c|c|c|c|}
\hline Test ID & $\begin{array}{c}\text { Initial } \\
\text { Mass } \\
(\mathrm{g}) \\
\end{array}$ & $\begin{array}{c}\text { Final } \\
\text { Mass } \\
(\mathrm{g}) \\
\end{array}$ & $\begin{array}{l}\text { Mass } \\
\text { Loss } \\
(\mathrm{g}) \\
\end{array}$ & $\begin{array}{c}1.5 \mathrm{~min} \\
\mathrm{D}_{\mathrm{s}}\end{array}$ & $\begin{array}{c}4.0 \mathrm{~min} \\
\mathrm{D}_{\mathrm{s}}\end{array}$ & $\begin{array}{c}\text { Maximum } \\
D_{s}\end{array}$ & $\begin{array}{l}\text { Time to } \\
\text { Max. } D_{s} \\
(\mathrm{sec})\end{array}$ & $\begin{array}{c}\text { Correction } \\
\text { Factor }\end{array}$ & $\begin{array}{l}\text { Corrected Max. } \\
\qquad D_{s}\end{array}$ \\
\hline $11-332 \mathrm{P} 1$ & 7.84 & 4.58 & 3.26 & 105.03 & 90.02 & 107.65 & 86 & 15.67 & 91.98 \\
\hline Average & 7.84 & 4.58 & 3.26 & 105.03 & 90.02 & 107.65 & 86 & 15.67 & 91.98 \\
\hline
\end{tabular}

\section{OBSERVATIONS}

\begin{tabular}{|c|c|c|c|c|c|c|c|c|}
\hline Test ID & $\begin{array}{l}\text { Observed } \\
\text { Smoke } \\
(\mathrm{sec})\end{array}$ & $\begin{array}{c}\text { Surface Char } \\
\text { (sec) }\end{array}$ & $\begin{array}{c}\text { Observed } \\
\text { Blistering } \\
\text { (sec) }\end{array}$ & $\begin{array}{l}\text { Time to } \\
\text { Ignition } \\
\text { (sec) }\end{array}$ & $\begin{array}{c}\text { Flames to } \\
\text { Top } \\
\text { (sec) }\end{array}$ & $\begin{array}{c}\text { Initial Flame } \\
\text { Out } \\
(\mathrm{sec})\end{array}$ & $\begin{array}{l}\text { Second } \\
\text { Ignition } \\
(\mathrm{sec})\end{array}$ & $\begin{array}{c}\text { Final Flame } \\
\text { Out } \\
(\mathrm{sec})\end{array}$ \\
\hline $11-332 \mathrm{P} 1$ & 2 & 1 & - & 1 & - & 58 & - & - \\
\hline Average & 2 & 1 & - & 1 & - & 58 & - & - \\
\hline
\end{tabular}

\section{OPTICAL DENSITY CHART}

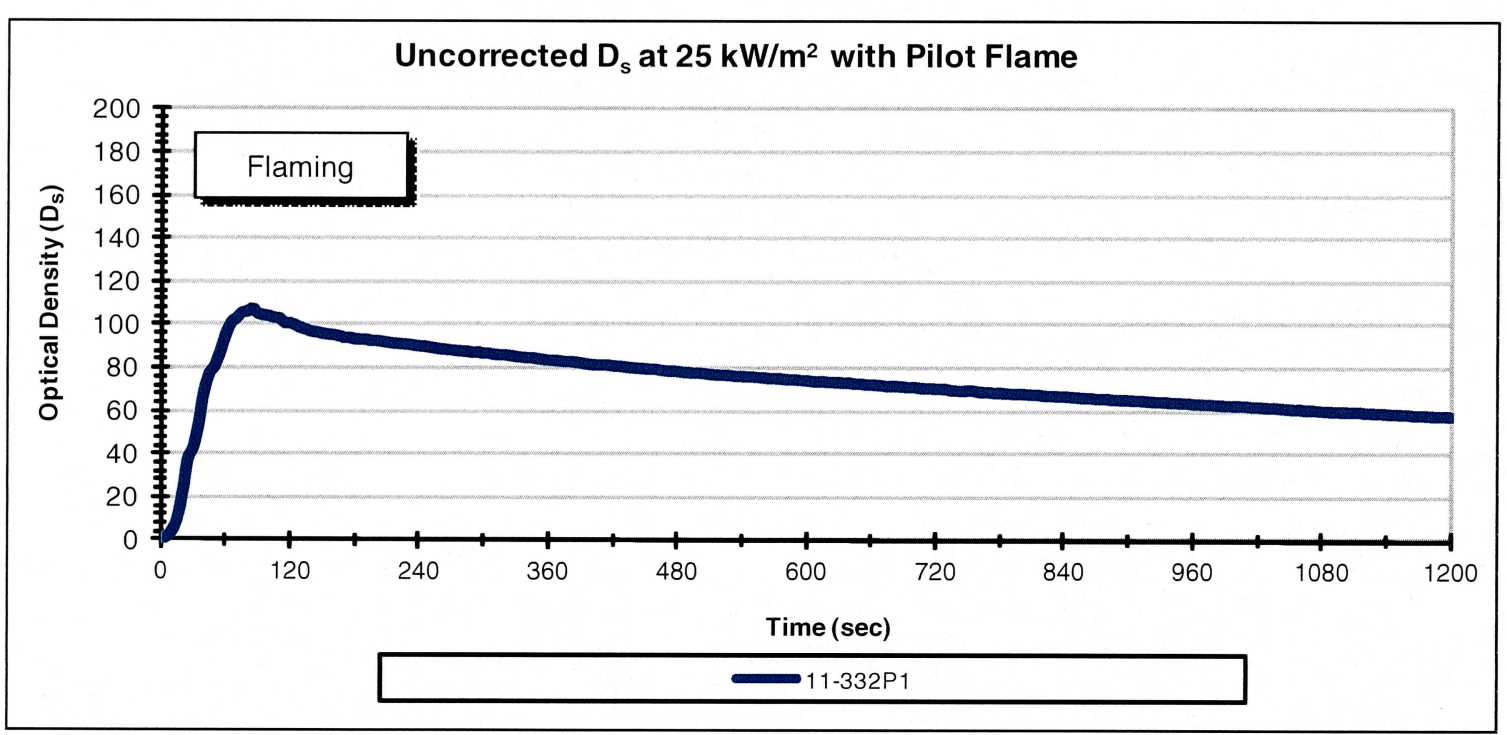

Figure 3. Smoke Density Results during Flaming Exposure - Standard. 


\section{SOUTHWEST RESEARCH INS TITUTE}

\section{ASTM E 662 SMOKE DENSITY TEST REPORT}

\begin{tabular}{|llll} 
Client: & Battelle Memorial Institute & Heat Flux: & $25 \mathrm{~kW} / \mathrm{m}^{2}$ \\
Operator: & P. Lopez & No pilot (nonflaming) \\
Test Date(s): & November 17,2011 & Horizontal \\
Project No. & $01.13295 .12 .008 f$ & Wxposure Mode: & White \\
Material ID*: & Standard Reference Material & Color: & $1.52 \mathrm{~mm}$ \\
Description*: & Reference Material from Fire Testing & Thickness: & November 16, 2011 \\
& Technologies - FTT reference material non- & Receipt Date: & Date Prepared by SwRI: Received ready-to-test \\
& flaming (1006d equivalent) (K159 Batch 2010) & Oven Cure Date: & None
\end{tabular}

* Information/instructions provided by the Client

RESULTS

\begin{tabular}{|c|c|c|c|c|c|c|c|c|c|}
\hline Test ID & $\begin{array}{c}\text { Initial } \\
\text { Mass } \\
(\mathrm{g})\end{array}$ & $\begin{array}{c}\text { Final } \\
\text { Mass } \\
(\mathrm{g}) \\
\end{array}$ & $\begin{array}{l}\text { Mass } \\
\text { Loss } \\
\text { (g) }\end{array}$ & $\begin{array}{c}1.5 \mathrm{~min} \\
\mathrm{D}_{\mathrm{s}}\end{array}$ & $\begin{array}{c}4.0 \mathrm{~min} \\
\mathrm{D}_{\mathrm{s}}\end{array}$ & $\begin{array}{c}\text { Maximum } \\
D_{s}\end{array}$ & $\begin{array}{l}\text { Time to } \\
\text { Max. } D_{\mathrm{s}} \\
(\mathrm{sec})\end{array}$ & $\begin{array}{c}\text { Correction } \\
\text { Factor }\end{array}$ & $\begin{array}{c}\text { Corrected Max. } \\
\qquad D_{s}\end{array}$ \\
\hline 11-321P1 & 3.21 & 0.01 & 3.20 & 17.99 & 148.07 & 178.69 & 485 & 28.55 & 150.14 \\
\hline Average & 3.21 & 0.01 & 3.20 & 17.99 & 148.07 & 178.69 & 485 & 28.55 & 150.14 \\
\hline
\end{tabular}

OBSERVATIONS

\begin{tabular}{|c|c|c|c|c|c|c|c|c|}
\hline Test ID & $\begin{array}{c}\text { Observed } \\
\text { Smoke } \\
(\mathrm{sec})\end{array}$ & $\begin{array}{c}\text { Surface Char } \\
(\mathrm{sec})\end{array}$ & $\begin{array}{c}\text { Observed } \\
\text { Blistering } \\
(\mathrm{sec})\end{array}$ & $\begin{array}{l}\text { Time to } \\
\text { Ignition } \\
\text { (sec) }\end{array}$ & $\begin{array}{c}\text { Flames to } \\
\text { Top } \\
(\mathrm{sec})\end{array}$ & $\begin{array}{c}\text { Initial Flame } \\
\text { Out } \\
\text { (sec) }\end{array}$ & $\begin{array}{l}\text { Second } \\
\text { Ignition } \\
\text { (sec) }\end{array}$ & $\begin{array}{c}\text { Final Flame } \\
\text { Out } \\
\text { (sec) }\end{array}$ \\
\hline 11-321P1 & 47 & 52 & - & - & - & - & - & - \\
\hline Average & 47 & 52 & - & - & - & - & - & - \\
\hline
\end{tabular}

OPTICAL DENSITY CHART

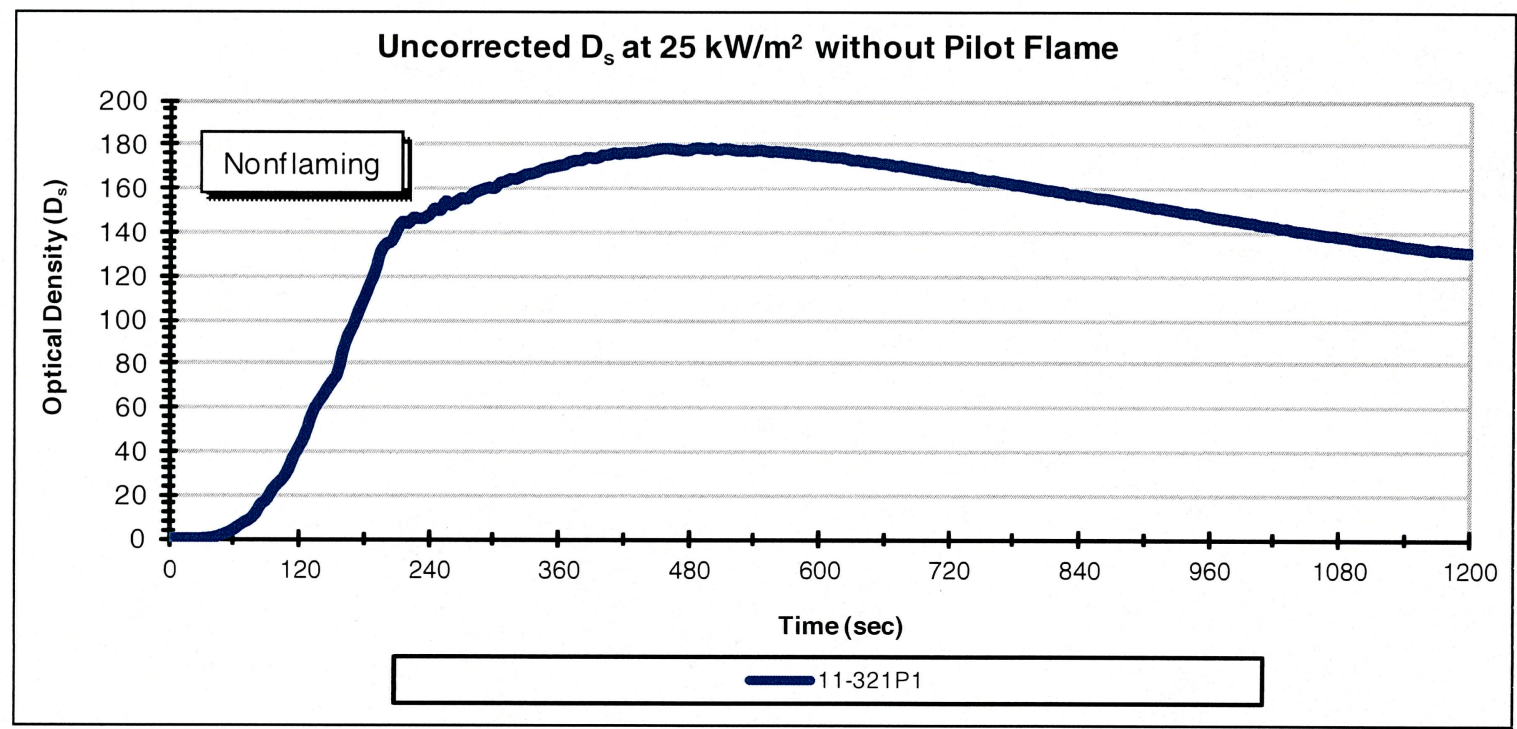

Figure 4. Smoke Density Results during Nonflaming Exposure - Standard. 
S OUTHWES T RESEARCH INS TITUTE

\section{ASTM E 662 SMOKE DENSITY TEST REPORT}

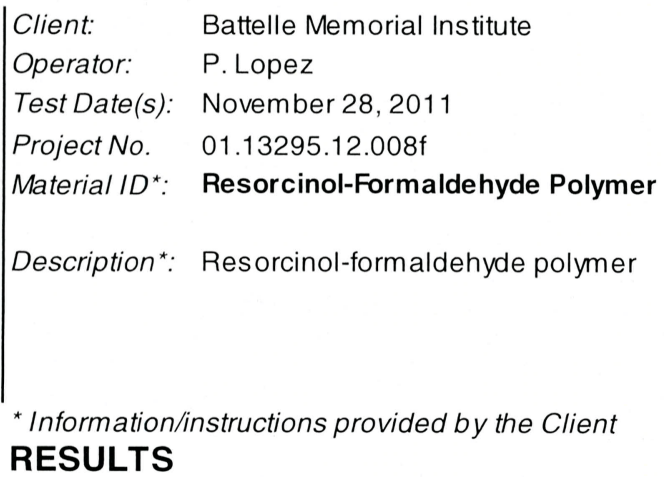

\begin{tabular}{|cccccccccc|}
\hline Test ID & $\begin{array}{c}\text { Initial } \\
\text { Mass }\end{array}$ & $\begin{array}{c}\text { Final } \\
\text { Mass }\end{array}$ & $\begin{array}{c}\text { Mass } \\
\text { Loss }\end{array}$ & $\begin{array}{c}1.5 \mathrm{~min} \\
\mathrm{D}_{\mathrm{s}}\end{array}$ & $\begin{array}{c}4.0 \mathrm{~min} \\
\mathrm{D}_{\mathrm{s}}\end{array}$ & $\begin{array}{c}\text { Maximum } \\
\mathrm{D}_{\mathrm{s}}\end{array}$ & $\begin{array}{c}\text { Time to } \\
\text { Max. } \mathrm{D}_{\mathrm{s}} \\
(\mathrm{g})\end{array}$ & $\begin{array}{c}\text { Correction Corrected Max. } \\
\text { Factor }\end{array}$ & $\begin{array}{c}\text { Coc } \\
\mathrm{D}_{\mathrm{s}}\end{array}$ \\
\hline $11-332 \mathrm{P} 2$ & 80.00 & 62.83 & 17.17 & 0.02 & 0.00 & 0.61 & 968 & 0.00 & 0.61 \\
$11-332 \mathrm{P} 3$ & 80.00 & 61.66 & 18.34 & 0.33 & 0.39 & 0.47 & 278 & 0.00 & 0.47 \\
$11-332 \mathrm{P} 4$ & 80.00 & 62.49 & 17.51 & 0.42 & 0.44 & 0.70 & 686 & 0.12 & 0.59 \\
\hline Average & 80.00 & 62.33 & 17.67 & 0.26 & 0.28 & 0.60 & 644 & 0.04 & $\mathbf{0 . 5 6}$ \\
\hline
\end{tabular}

\section{OBSERVATIONS}

\begin{tabular}{|lcccccccc|}
\hline Test ID & $\begin{array}{c}\text { Observed } \\
\text { Smoke } \\
(\mathrm{sec})\end{array}$ & $\begin{array}{c}\text { Surface Char } \\
(\mathrm{sec})\end{array}$ & $\begin{array}{c}\text { Observed } \\
\text { Blistering } \\
(\mathrm{sec})\end{array}$ & $\begin{array}{c}\text { Time to } \\
\text { Ignition } \\
(\mathrm{sec})\end{array}$ & $\begin{array}{c}\text { Flames to Initial Flame } \\
\text { Top }\end{array}$ & $\begin{array}{c}\text { Second } \\
\text { Out }\end{array}$ & $\begin{array}{c}\text { Final Flame } \\
\text { Ignition } \\
\text { Out }\end{array}$ & $\begin{array}{c}\text { (sec) } \\
(\mathrm{sec})\end{array}$ \\
\hline $11-332 \mathrm{P} 2$ & - & 42 & - & 678 & - & - & - & - \\
$11-332 \mathrm{P} 3$ & - & 38 & - & - & - & - & - & - \\
$11-332 \mathrm{P} 4$ & - & 44 & - & 641 & - & - & - & - \\
\hline Average & - & 41 & - & 660 & - & - & - & - \\
\hline
\end{tabular}

\section{OPTICAL DENSITY CHART}

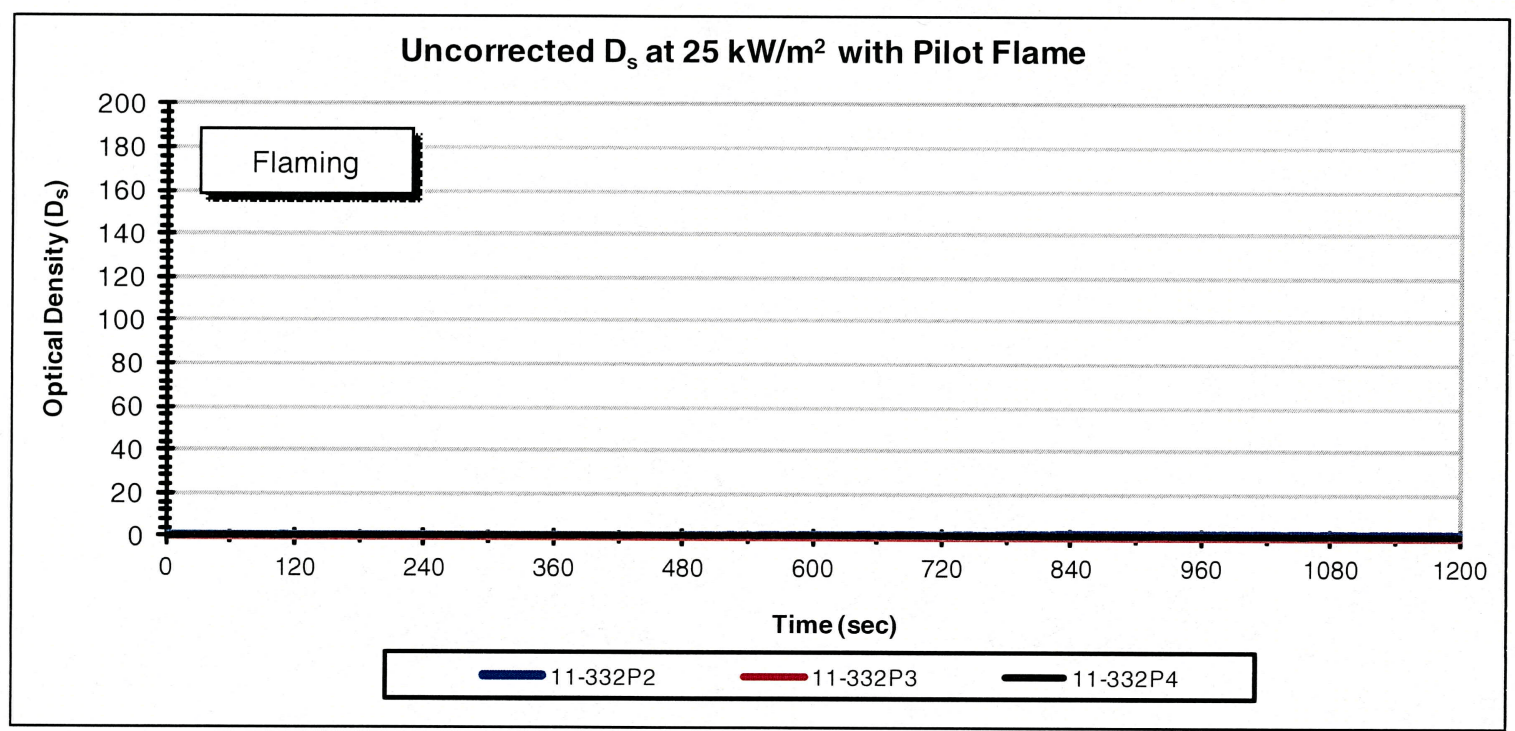

Figure 5. Smoke Density Results during Flaming Exposure - Resorcinol-Formaldehyde Polymer. 


\title{
SOUTHWEST RESEARCH INS TITUTE
}

\section{ASTM E 662 SMOKE DENSITY TEST REPORT}

\author{
Client: $\quad$ Battelle Memorial Institute \\ Operator: P. Lopez \\ Test Date(s): November 18, 2011 \\ Project No. $\quad 01.13295 .12 .008 f$ \\ Material ID*: Resorcinol-Formaldehyde Polymer \\ Description*: Resorcinol-formaldehyde polymer \\ * Information/instructions provided by the Client
}

Heat Flux:
Exposure Mode:
Orientation:
Color:
Thickness:
Receipt Date:
Date Prepared by SwRI:
Oven Cure Date:
Note:

$25 \mathrm{~kW} / \mathrm{m}^{2}$

No pilot (nonflaming)

Horizontal

Orange to dark red

$25 \mathrm{~mm}$

November 11, 2011

Tested as received

Minim um of $24 \mathrm{~h}$

Tested solid component without water

\section{RESULTS}

\begin{tabular}{|ccccccccccc|}
\hline \multirow{2}{*}{ Test ID } & $\begin{array}{c}\text { Initial } \\
\text { Mass }\end{array}$ & $\begin{array}{c}\text { Final } \\
\text { Mass }\end{array}$ & $\begin{array}{c}\text { Mass } \\
\text { Loss }\end{array}$ & $\begin{array}{c}1.5 \mathrm{~min} \\
\mathrm{D}_{\mathrm{s}}\end{array}$ & $\begin{array}{c}4.0 \mathrm{~min} \\
\mathrm{D}_{\mathrm{s}}\end{array}$ & $\begin{array}{c}\text { Maximum } \\
\mathrm{D}_{\mathrm{s}}\end{array}$ & $\begin{array}{c}\text { Time to } \\
\text { Max. } \mathrm{D}_{\mathrm{s}} \\
(\mathrm{g})\end{array}$ & $\begin{array}{c}\text { Correction } \\
\text { Factor }\end{array}$ & $\begin{array}{c}\text { Corrected Max. } \\
\mathrm{D}_{\mathrm{s}}\end{array}$ \\
\hline $11-322 \mathrm{P} 1$ & 83.50 & 65.40 & 18.10 & 0.20 & 0.28 & 0.40 & 475 & 0.00 & 0.40 \\
$11-322 \mathrm{P} 2$ & 83.50 & 63.52 & 19.98 & 0.23 & 0.18 & 0.36 & 416 & 0.00 & 0.36 \\
$11-322 \mathrm{P3}$ & 83.50 & 64.96 & 18.54 & 0.19 & 0.22 & 0.57 & 1165 & 0.44 & 0.13 \\
& & & & & & & & & & \\
\hline Average & 83.50 & 64.63 & 18.87 & 0.21 & 0.22 & 0.44 & 685 & 0.15 & $\mathbf{0 . 3 0}$ \\
\hline
\end{tabular}

\section{OBSERVATIONS}

\begin{tabular}{|lcccccccc|}
\hline Test ID & $\begin{array}{c}\text { Observed } \\
\text { Smoke } \\
(\mathrm{sec})\end{array}$ & $\begin{array}{c}\text { Surface Char } \\
(\mathrm{sec})\end{array}$ & $\begin{array}{c}\text { Observed } \\
\text { Blistering } \\
(\mathrm{sec})\end{array}$ & $\begin{array}{c}\text { Time to } \\
\text { Ignition } \\
(\mathrm{sec})\end{array}$ & $\begin{array}{c}\text { Flames to } \\
\text { Top }\end{array}$ & $\begin{array}{c}\text { Initial Flame } \\
\text { Out }\end{array}$ & $\begin{array}{c}\text { Second } \\
\text { Ignition } \\
(\mathrm{sec})\end{array}$ & $\begin{array}{c}\text { Final Flame } \\
\text { Out }\end{array}$ \\
\hline $11-322 \mathrm{Pec} 1$ & - & 43 & - & - & - & - & - & - \\
$11-322 \mathrm{P} 2$ & - & 41 & - & - & - & - & - & - \\
$11-322 \mathrm{P} 3$ & - & 39 & - & - & - & - & - & - \\
\hline Average & - & 41 & - & - & - & - & - & - \\
\hline
\end{tabular}

\section{OPTICAL DENSITY CHART}

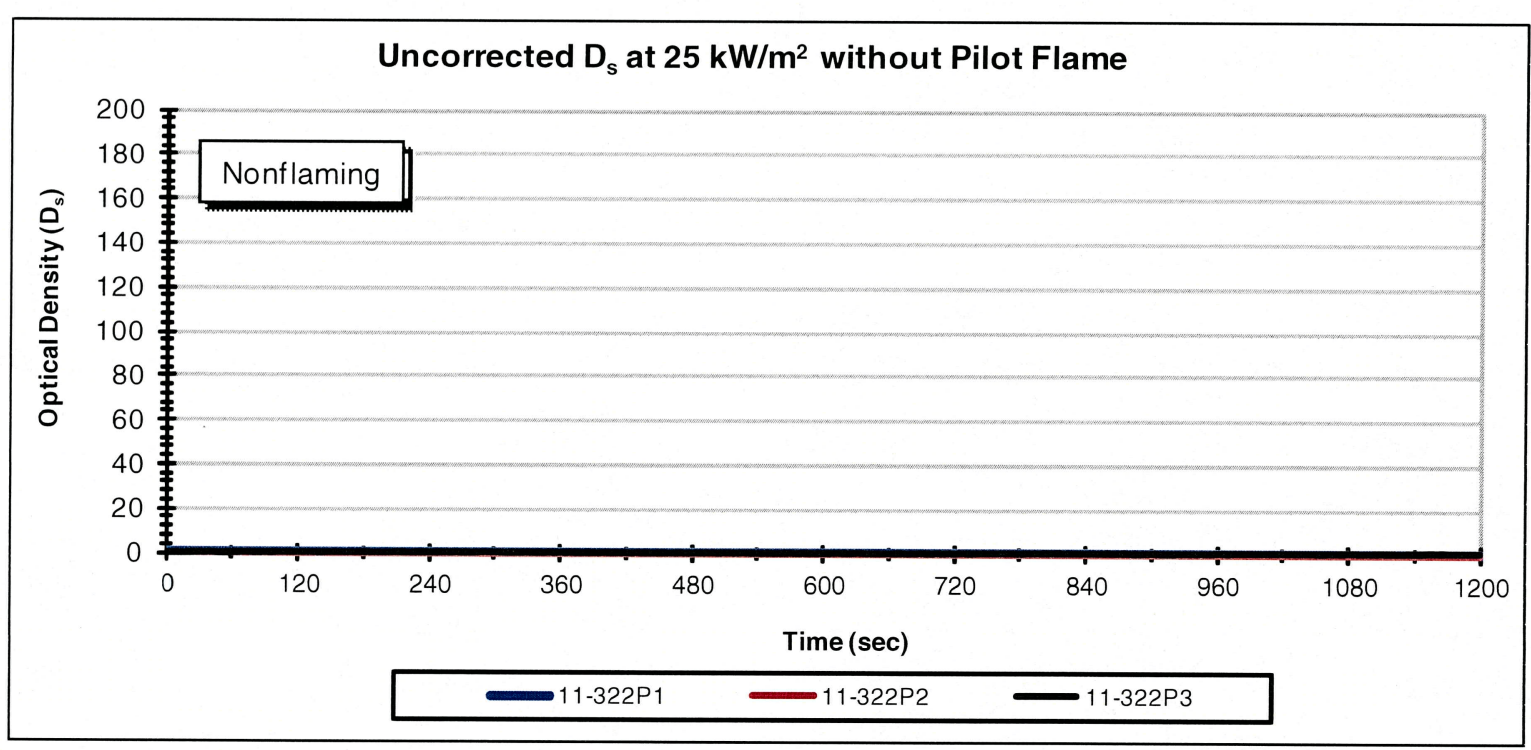

Figure 6. Smoke Density Results during Nonflaming Exposure - Resorcinol-Formaldehyde Polymer. 
S OUTHWES T RES EARCH INS TITUTE

\title{
ASTM E 662 SMOKE DENSITY TEST REPORT
}

\author{
Client: Battelle Memorial Institute \\ Operator: P. Lopez \\ Test Date(s): November 29, 2011 \\ Project No. $\quad 01.13295 .12 .008 \mathrm{f}$ \\ Material ID*: Resorcinol-Formaldehyde Polymer \\ Duplicate Tests \\ Description*: Resorcinol-formaldehyde polymer \\ * Information/instructions provided by the Client
}

$\mid \begin{aligned} & \text { Heat Flux: } \\ & \text { Exposure Mode: } \\ & \text { Orientation: } \\ & \text { Color: } \\ & \text { Thickness: } \\ & \text { Receipt Date: } \\ & \text { Date Prepared by SwRI: } \\ & \text { Oven Cure: } \\ & \text { Note: }\end{aligned}$

$25 \mathrm{~kW} / \mathrm{m}^{2}$

Piloted (Flaming)

Horizontal

Orange to dark red

$25 \mathrm{~mm}$

November 11, 2011

Tested as received

Minimum of $24 \mathrm{~h}$

Tested solid component without water

\section{RESULTS}

\begin{tabular}{|ccccccccccc|}
\hline \multirow{2}{*}{ Test ID } & $\begin{array}{c}\text { Initial } \\
\text { Mass }\end{array}$ & $\begin{array}{c}\text { Final } \\
\text { Mass }\end{array}$ & $\begin{array}{c}\text { Mass } \\
\text { Loss }\end{array}$ & $\begin{array}{c}1.5 \mathrm{~min} \\
\mathrm{D}_{\mathrm{s}}\end{array}$ & $\begin{array}{c}4.0 \mathrm{~min} \\
\mathrm{D}_{\mathrm{s}}\end{array}$ & $\begin{array}{c}\text { Maximum } \\
\mathrm{D}_{\mathrm{s}}\end{array}$ & $\begin{array}{c}\text { Time to } \\
\text { Max. } \mathrm{D}_{\mathrm{s}} \\
(\mathrm{g})\end{array}$ & $\begin{array}{c}\text { Correction Corrected Max. } \\
\text { Factor }\end{array}$ & $\begin{array}{c}\text { Coc } \\
\mathrm{D}_{\mathrm{s}}\end{array}$ \\
\hline $11-333 \mathrm{P} 1$ & 80.00 & 62.45 & 17.55 & 0.05 & 0.04 & 0.15 & 747 & 0.00 & 0.15 \\
$11-333 \mathrm{P} 2$ & 80.00 & 63.01 & 16.99 & 0.61 & 0.74 & 1.14 & 836 & 0.69 & 0.45 \\
$11-333 \mathrm{P3}$ & 80.00 & 62.33 & 17.67 & 0.41 & 0.54 & 0.83 & 1198 & 0.20 & 0.62 \\
\hline Average & 80.00 & 62.60 & 17.40 & 0.36 & 0.44 & 0.70 & 927 & 0.30 & $\mathbf{0 . 4 1}$ \\
\hline
\end{tabular}

\section{OBSERVATIONS}

\begin{tabular}{|c|c|c|c|c|c|c|c|c|}
\hline Test ID & $\begin{array}{c}\text { Observed } \\
\text { Smoke } \\
\text { (sec) }\end{array}$ & $\begin{array}{c}\text { Surface Char } \\
\text { (sec) }\end{array}$ & $\begin{array}{c}\text { Observed } \\
\text { Blistering } \\
\text { (sec) }\end{array}$ & $\begin{array}{l}\text { Time to } \\
\text { Ignition } \\
\text { (sec) }\end{array}$ & $\begin{array}{c}\text { Flames to } \\
\text { Top } \\
(\mathrm{sec})\end{array}$ & $\begin{array}{c}\text { Initial Flame } \\
\text { Out } \\
\text { (sec) }\end{array}$ & $\begin{array}{l}\text { Second } \\
\text { Ignition } \\
(\mathrm{sec})\end{array}$ & $\begin{array}{c}\text { Final Flame } \\
\text { Out } \\
\text { (sec) }\end{array}$ \\
\hline 11-333P1 & - & 40 & - & 606 & - & - & - & - \\
\hline 11-333Р2 & - & 36 & - & 629 & - & - & - & - \\
\hline 11-333Р3 & - & 40 & - & 605 & - & - & - & - \\
\hline Average & - & 39 & - & 613 & - & - & - & - \\
\hline
\end{tabular}

\section{OPTICAL DENSITY CHART}

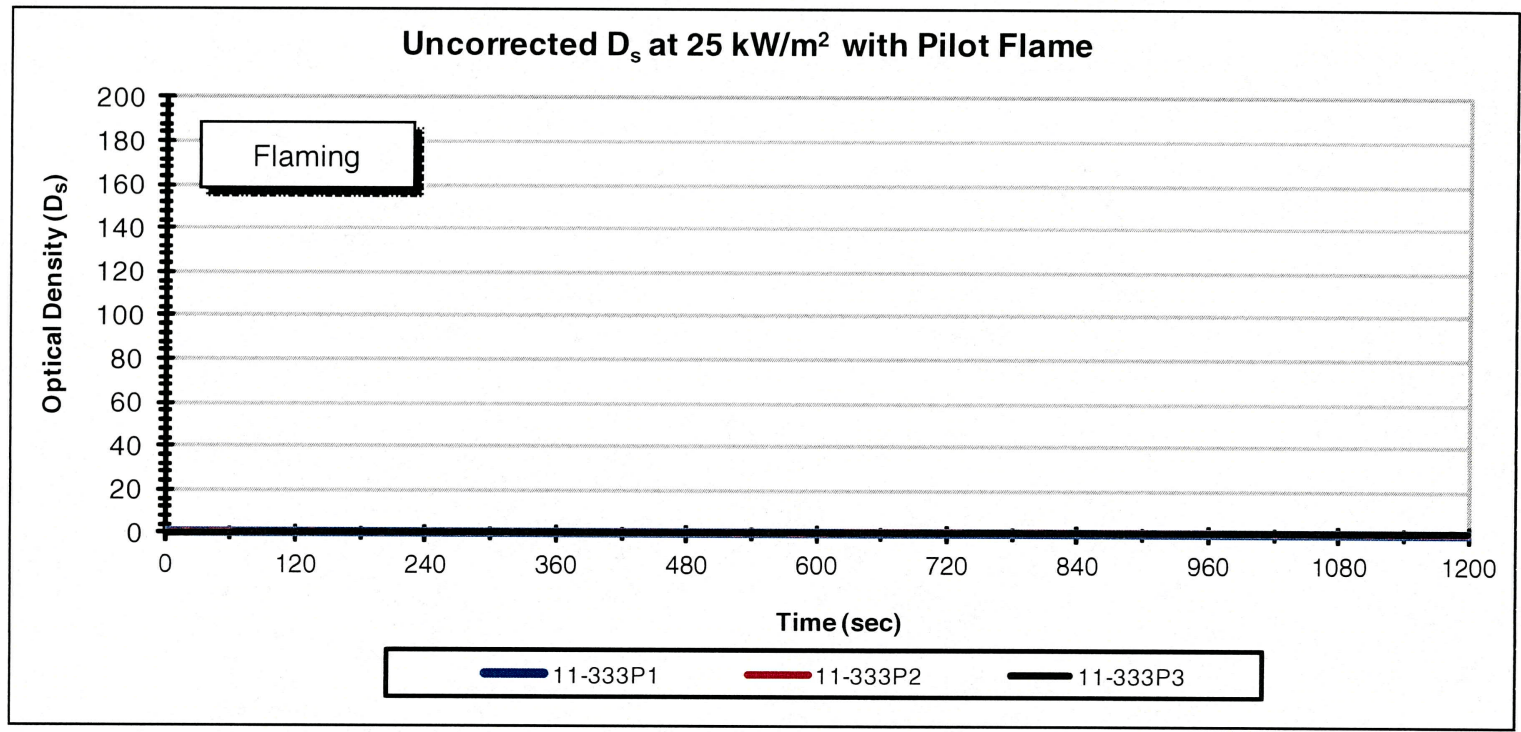

Figure 7. Smoke Density Results during Flaming Exposure - Resorcinol-Formaldehyde Polymer. 
S OUTHW ES T RES EAR CH INS TITUTE

\section{ASTM E 662 SMOKE DENSITY TEST REPORT}

Client: Battelle Memorial Institute

Operator: P.Lopez

Test Date(s): November 18 and 19, 2011

Project No. 01.13295.12.008f

Material ID*: Resorcinol-Formaldehyde Polymer Duplicate Tests

Description*: Resorcinol-formaldehyde polymer

* Information/instructions provided by the Client

Heat Flux:
Exposure Mode:
Orientation:
Color:
Thickness:
Receipt Date:
Date Prepared by SwRI:
Oven Cure Date:
Note:

$25 \mathrm{~kW} / \mathrm{m}^{2}$

No pilot (nonflaming)

Horizontal

Orange to dark red

$25 \mathrm{~mm}$

November 11, 2011

Tested as received

Minimum of $24 \mathrm{~h}$

Tested solid component without water

\section{RESULTS}

\begin{tabular}{|c|c|c|c|c|c|c|c|c|c|}
\hline Test ID & $\begin{array}{c}\text { Initial } \\
\text { Mass } \\
\text { (g) }\end{array}$ & $\begin{array}{c}\text { Final } \\
\text { Mass } \\
(\mathrm{g})\end{array}$ & $\begin{array}{c}\text { Mass } \\
\text { Loss } \\
(\mathrm{g})\end{array}$ & $\begin{array}{c}1.5 \mathrm{~min} \\
\mathrm{D}_{\mathrm{s}}\end{array}$ & $\begin{array}{c}4.0 \mathrm{~min} \\
\mathrm{D}_{\mathrm{s}}\end{array}$ & $\begin{array}{c}\text { Maximum } \\
D_{\mathrm{s}}\end{array}$ & $\begin{array}{c}\text { Time to } \\
\text { Max. D } \\
\text { (sec) }\end{array}$ & $\begin{array}{c}\text { Correction } \\
\text { Factor }\end{array}$ & $\begin{array}{c}\text { Corrected Max. } \\
\qquad D_{s}\end{array}$ \\
\hline $11-322 P 4$ & 83.50 & 67.00 & 16.50 & 0.08 & 0.03 & 0.24 & 587 & 0.00 & 0.24 \\
\hline $11-322 P 5$ & 83.50 & 67.23 & 16.27 & 0.18 & 0.10 & 0.28 & 37 & 0.00 & 0.28 \\
\hline 11-323P1 & 83.50 & 66.52 & 16.98 & 0.18 & 0.23 & 0.27 & 239 & 0.17 & 0.11 \\
\hline Average & 83.50 & 66.92 & 16.58 & 0.15 & 0.12 & 0.26 & 288 & 0.06 & 0.21 \\
\hline
\end{tabular}

\section{OBSERVATIONS}

\begin{tabular}{|c|c|c|c|c|c|c|c|c|}
\hline Test ID & $\begin{array}{l}\text { Observed } \\
\text { Smoke } \\
\text { (sec) }\end{array}$ & $\begin{array}{c}\text { Surface Char } \\
\text { (sec) }\end{array}$ & $\begin{array}{c}\text { Observed } \\
\text { Blistering } \\
\text { (sec) }\end{array}$ & $\begin{array}{l}\text { Time to } \\
\text { Ignition } \\
\text { (sec) }\end{array}$ & $\begin{array}{c}\text { Flames to } \\
\text { Top } \\
\text { (sec) }\end{array}$ & $\begin{array}{c}\text { Initial Flame } \\
\text { Out } \\
\text { (sec) }\end{array}$ & $\begin{array}{l}\text { Second } \\
\text { Ignition } \\
\text { (sec) }\end{array}$ & $\begin{array}{c}\text { Final Flame } \\
\text { Out } \\
\text { (sec) }\end{array}$ \\
\hline $11-322 P 4$ & - & 44 & - & - & - & - & - & - \\
\hline 11-322P5 & - & 41 & - & - & - & - & - & - \\
\hline 11-323P1 & - & 52 & - & - & - & - & - & - \\
\hline Average & - & 46 & - & - & - & - & - & - \\
\hline
\end{tabular}

\section{OPTICAL DENSITY CHART}

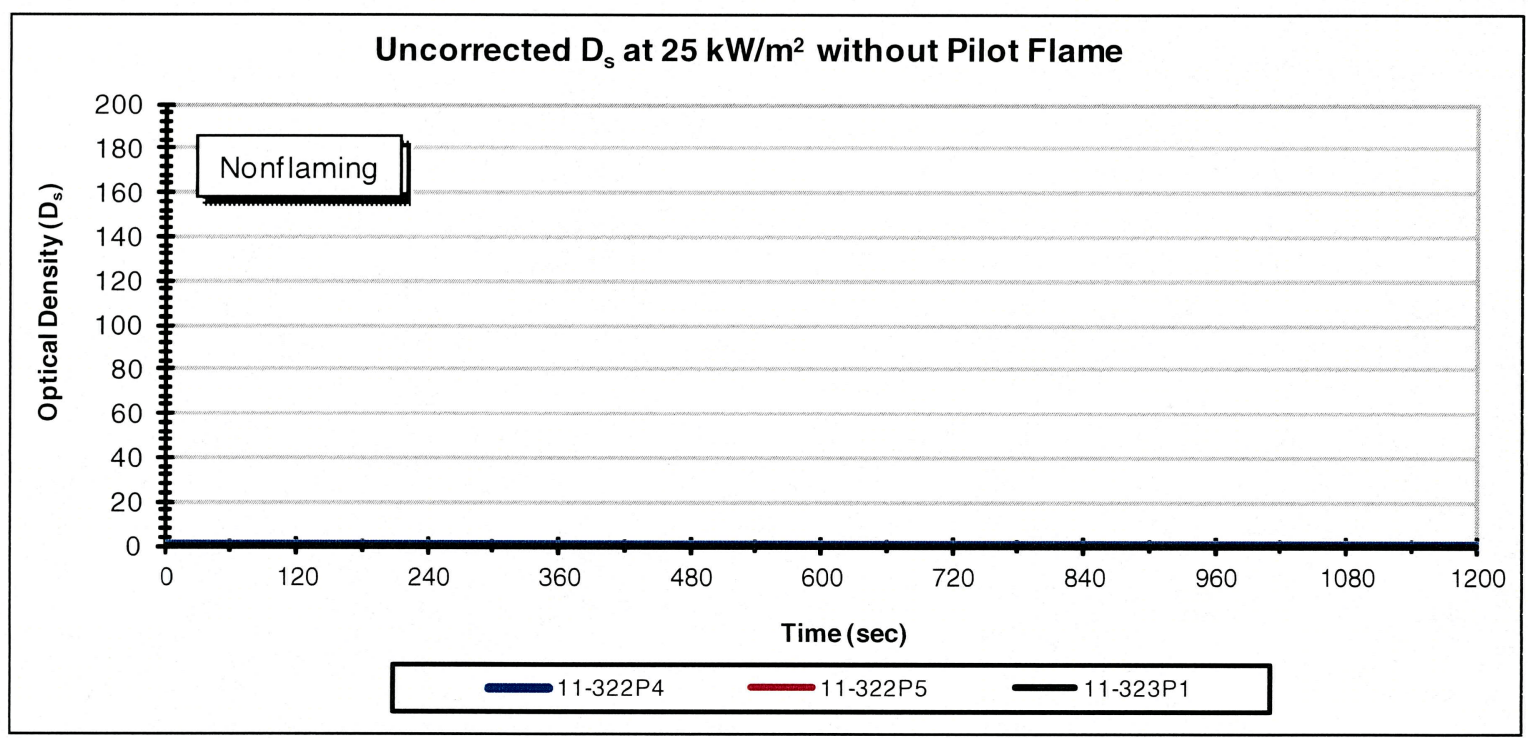

Figure 8. Smoke Density Results during Nonflaming Exposure - Resorcinol-Formaldehyde Polymer. 
SOUTHWEST RESEARCH INSTITUTE CLIENT: Battelle Memorial Ins. PNNL TASK ORDER\#:

SRR\#:

111111-12

SDG\#:

46069

VTSR:

479235

PROJECT \#:

$11 / 11 / 2011$

13295.12.00X

\section{R13295.12.008 Instrumentation Record Sheets}


Southwest Research Institute

Chemistry and Chemical Engineering Division

Department of Fire Technology

\section{INSTRUMENTATION RECORD SHEET}

\begin{tabular}{|c|c|c|c|c|}
\hline Client: & Batt & elle PNNL & & \\
\hline Project No.: & 01.1 & 2195.12 .008 & & \\
\hline Test Date: & Nov & 17,2011 & & \\
\hline Test ID: & ASTM & D 7309 & & \\
\hline Critical Equipment & & Manufacturer & Model Number & Serial Number \\
\hline FLOW CONTROLER & & MKS & $1179 \mathrm{~A} 12 \mathrm{CS} 1 \mathrm{BVBZ}$ & 080363323 \\
\hline FLOW CONTROLER & & MKS & $179 \mathrm{~A} 22 \mathrm{CS} 3 \mathrm{BMBZ}$ & 080363326 \\
\hline FLOW CONTROLER & & MKS & 1179A51CS1BVCG & 080363325 \\
\hline BALANCE & & DENVER & $P I-225 D$ & 23202158 \\
\hline CLASS F WEIGHT & & UNKNOWN & $\mathrm{N} / \mathrm{A}$ & 12451 \\
\hline DATA ACQUISITION/CONTROL & UNIT & YOKOGAWA & DU100-11 & $12 \mathrm{BB} 23175$ \\
\hline $\begin{array}{l}\text { Personnel List: } \\
\text { A. Lowry } \\
\text { Nathaniel Ramos }\end{array}$ & & & & \\
\hline $\begin{array}{l}\text { Relative Humidity: } \\
\text { Ambient Temperature: }\end{array}$ & & $\begin{array}{ll}50 & 8 \\
23 & { }^{\circ} \mathrm{C}\end{array}$ & & \\
\hline
\end{tabular}


Southwest Research Institute Chemistry and Chemical Engineering Division

Department of Fire Technology

\section{INSTRUMENTATION RECORD SHEET}

\begin{tabular}{|c|c|c|c|}
\hline Client: & Battelle PNNL & & \\
\hline Project No.: & 01.13295 .12 .008 & & \\
\hline Test Date: & Nov 17,2011 & & \\
\hline Test ID: & ASTM E-1354 & & \\
\hline Critical Equipment & Manufacturer & Model Number & Serial Number \\
\hline BALANCE & METTLER TOLEDO & B3001 & 1117512563 \\
\hline CH4 FLOW METER & BRONKHORST & $F-112 A C-A A D-33-V$ & M7205789A \\
\hline CALIPER & MITUTOYO & $C D-8 " P S$ & 06616887 \\
\hline CLASS F WEIGHT & UNKNOWN & $\mathrm{N} / \mathrm{A}$ & 12451 \\
\hline DATA LOGGER & OMEGA & OM- 73 & 0510201028 \\
\hline SCHMIDT-BOELTER & MEDTHERM CORPOR & GTW-10-32-485A & 99161 \\
\hline \multicolumn{4}{|l|}{$\begin{array}{l}\text { Personnel List: } \\
\text { Alan K Lowry }\end{array}$} \\
\hline $\begin{array}{l}\text { Relative Humidity: } \\
\text { Ambient Temperature: }\end{array}$ & $\begin{array}{l}50 \% \\
23{ }^{\circ} \mathrm{C}\end{array}$ & & \\
\hline
\end{tabular}

Next Cal Due

Nov 25,2011

May 17,2012

Feb 9, 2012

May 16, 2012

Apr 19, 2012

$\operatorname{Mar} 11,2012$ 
Mayces, Tom

From:

Sent:

To:

Cc:

Subject:
Ehnstrom, Mark R.

Tuesday, November 29, 2011 8:12 AM

Tom Mayces (tom.mayces@swri.edu)

Lopez, Priscilla

Div.01

Mr. Mayces,

Yesterday I did surveillance on the Div. 01 project that you started last week. I think the client is Bechtel. Here is the information for the test I witnessed yesterday:

Flowmeters:

Asst \# 012391

012392

Radiometer:

011860

Pressure Transducer:

012828

Scale:

004688

$1 / 29 / 11$

$12 / 29 / 11$

0-6" Caliper

011786
Cal. Date $1 / 20 / 11$

$8 / 23 / 11$

Cal Due 12/20/11

$8 / 23 / 12$
$9 / 22 / 12$

The test performed was a "Flaming IMO Part 2 Test". It was a 20 minute test and because of the material provided by the client, it was a E662 compliant test. I didn't know if you were going to do a surveillance report or not.

Best regards,

Mark 
SOUTHWEST RESEARCH INSTITUTE CLIENT: Battelle Memorial Ins. PNNL TASK ORDER\#:

SRR\#:

111111-12

SDG\#:

VTSR:

46069

479235

PROJECT \#:

$11 / 11 / 2011$

13295.12.00X

\section{SAMPLE RECEIPT, TASK ORDER \\ \& CHAIN OF CUSTODY}


Southwest Research Institute

Project: $\quad 13295.12 .00 X$

Case \#: $\quad 167930$

Client: BATTELLE PNNL
Sample Receipt

Manager: HORTON, GENE Logged in by: DROMAN

Creation Date: 11/11/11

\section{Notes}

Samples were received intact at $22.0^{\circ} \mathrm{C}$ (No ice).

Fed Ex \#404742686287

Parameters: Analysis/located on Task Order.

See chain-of-custody as part of the SRR system for more information.

Phases:

001 - admin

007 - drg

008 - Fire Tech

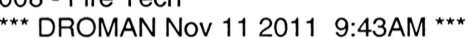

\begin{tabular}{|c|c|c|c|c|c|c|c|}
\hline System ID & \multicolumn{1}{|c|}{ Customer ID } & CED & Matrix & Containers & Special Regs. \\
\hline 479235 & RESORCINOL-FORMALDEHYDE POLYMER & & Liquid & 1 \\
\hline
\end{tabular}

These documents are associated with this receipt: 109898[COC for SRR 46069], 109900[MSDS for SRR 46069],

109148[RFP \#190709], 109444[Tech Prop], 109445[Cost Prop], 109773[Contract 167930]
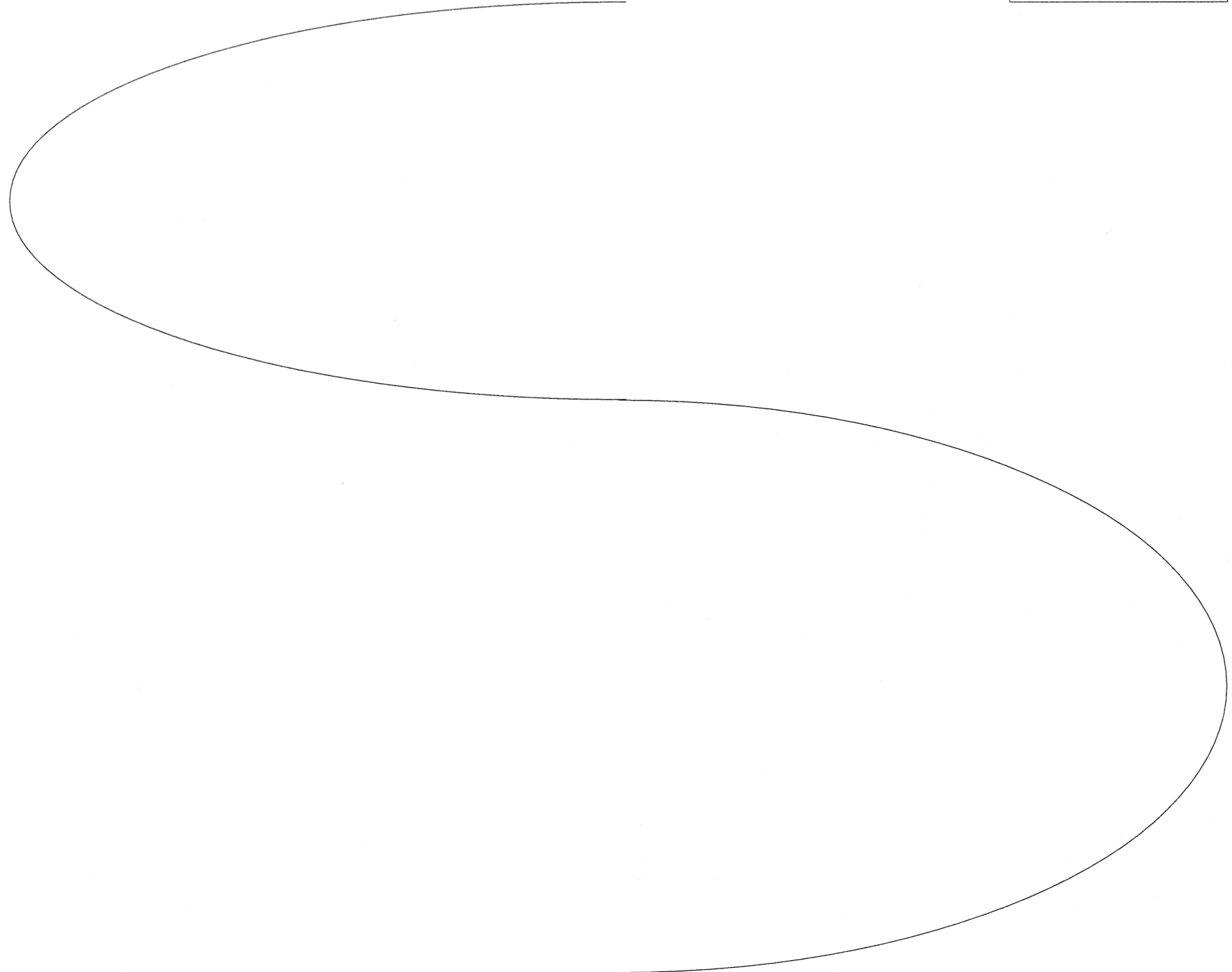


\section{Instructions}

BATTELLE MEMORIAL INSTITUTE - PACIFIC NORTHWEST NATIONAL LABORATORY. (BATTELLE PNNL) RFP 190709. CONTRACT \#167930

17-DAY TAT FOR PRELIMINARY RESULTS.

33-DAY TAT FOR FINAL DATA PACKAGE TO CLIENT.

1 OVERALl SAMple ( 1 CONTAINERS) RECEIVED ON 11/11/11 FOR THE REQUESTED ITEMS UNDER RFP 190709. PLEASE CONTACT GENE HORTON X3457 WITH ANY ADDITIONAL QUESTIONS OR ALSO SEE THE RFP.

BRIEF SUMMARY OF REQUIREMENTS:

RESIN FLASH IGNITION TEMPERATURE (FIT) CONE CALORIMETER \& HOT-AIR FURNACE METHOD ASTM D 1929 CRITICAL HEAT FLUX (PERFORMED PRIOR TO REGULAR 1354 TEST) CONE CALORIMETER ASTM E 1354

HEAT RELEASE RATES, MASS LOSS RATES CALCULATED THERMAL RESPONSE PARAMETER (TRP) $\square$ CONE CALORIMETER ASTM E 1354

EFFECTIVE HEATS OF COMBUSTION VALUES OBTAINED THROUGH THERMAL DECOMPOSITION MICROSCALE COMBUSTION CALORIMETER ASTM D 7309-07A, METHOD A

NET CALORIFIC VALUE OR NET HEAT OF COMBUSTION VS. TOTAL HEAT OF COMBUSTION. VALUES OBTAINED THROUGH OXIDATIVE DECOMPOSITION MICROSCALE COMBUSTION CALORIMETER ASTM D 7309-07B METHOD B SOOT AND SMOKE YIELD FTIR ASTM E8OOC 2

PARTICLE SIZE DISTRIBUTION OF GENERATED PARTICLES PARTICLE CAPTURE DURING ADDITIONAL TEST ASTM 662

VISIBLE SMOKE DEVELOPMENT SPECIFIC OPTICAL DENSITY OF SMOKE ASTM E 662

SAMPLE PREPARATION ALL TESTS

CLIENT CONTACT IS MS. RENEE RUSSELL 509.372.4708, RENEE.RUSSELL@PNL.GOV; PROJECT MANAGER REID PETERSON 509.375.2464.

HASQARD REQUIREMENTS. SEE ALSO SOW 58008.

EMAIL PRELIMINARY RESULTS TO:

RENEE.RUSSELL@PNNL.GOV; REID.PETERSON@PNNL.GOV; MICHAEL SCHWEIGER MIKE.SCHWEIGER@PNNL.GOV.

ALSO INCLUDE A COPY OF THE E-MAIL FOR THE PRELIM RESULTS IN THE DATA PACKAGE FOR THE FINAL REPORT. THIS SERVES AS DOCUMENTATION THAT THE TAT WAS MET.

FINAL HARDCOPY / CD TO (FULL RAW DATA PACKAGE) :

BATTELLE PNNL FOR US DOE

7906 TH STREET

RICHLAND, WA 99354

ATTN: PO \#167930, RENEE RUSSELL K6-24

REVISION 1, DRMZ 11/14/11: TASK ORDER REVISED TO CORRECT THE DATE RECEIVED REFERENCED UNDER THE INSTRUCTIONS TO $11 / 11 / 11$.

Documents Related to this task order: 109898[COC for SRR 46069], 109900[MSDS for SRR 46069], 109148 [RFP \#190709], 109444[Tech Prop], 109445[Cost Prop], 109773 [Contract 167930]

Deliverables --> Hard Copy: -YES- EDD: no PDF: -YES-

Test: ARCH_DRG

Holding: 365 days from CED

Section: DATA REPORTING Archive a copy for records/billing

Cnt: 1

\begin{tabular}{|l|c|c|c|c|c|c|}
\hline System ID & Type & Cont & Matrix & Customer ID & CED \\
\hline 479235 & & 1 & Liquid & RESORCINOL-FORMALDEHYDE POLYMER & \\
\hline
\end{tabular}

Test: ASTM D1929

Section: FT ADMIN
Holding: 30 days from VTSR

Standard Test Method For Determining Ignition Temperature Of Plastics

Cnt: 1

\begin{tabular}{|l|c|c|c|c|c|c|}
\hline System ID & Type & Cont & Matrix & Customer ID & VTSR & Method Date \\
\hline 479235 & & 1 & Liquid & RESORCINOL-FORMALDEHYDE POLYMER & 11 Nov 11 & 11 DeC 11 \\
\hline
\end{tabular}


SDG: 479235

VTSR: $11 / 11 / 11$

RFP: 190709
SRR \#'s: 46069

Client(s): BATTELLE PNNL
Project(s): 13295.12.00X

Manager(s): HORTON, GENE

To PM: $11 / 28 / 11$

To QA: $12 / 13 / 11$

To Client: $12 / 14 / 11$

Test: ASTM D7309

Holding: 14 days from VTSR

Section: FT ADMIN

Standard Test Method for Determining Flammability Characteristics of Plastics and Other Solid Materials Using Microscale Combustion Calorimetry

\begin{tabular}{|l|c|c|c|c|c|c|}
\hline System ID & Type & Cont & \multicolumn{1}{|c|}{ Matrix } & Customer ID & Method Date \\
\hline 479235 & & 1 & Liquid & RESORCINOL-FORMALDEHYDE POLYMER & 11 NOV 11 & 25 NOV 11 \\
\hline
\end{tabular}

Test: ASTM E1354

Section: FT ADMIN
Holding: 30 days from VTSR

Standard Test Method For Heat And Visible Smoke Release Rates For Materials And Products Using An Oxygen Consumption Calorimeter (Cone Calorimeter)

\begin{tabular}{|l|c|c|c|c|c|c|}
\hline \multicolumn{1}{|c|}{ System ID } & Type & Cont & \multicolumn{1}{c|}{ Matrix } & Customer ID & VTSR & Method Date \\
\hline 479235 & & 1 & Liquid & RESORCINOL-FORMALDEHYDE POLYMER & 11 Nov 11 & 11 DeC 11 \\
\hline
\end{tabular}

Test: ASTM E662

Section: FT ADMIN
Holding: 30 days from VTSR

Standard Test Method For Specific Optical Density Of Smoke Generated By Solid Materials (Smoke Chamber)

\begin{tabular}{|l|c|c|c|c|c|c|}
\hline System ID & Type & Cont & Matrix & Customer ID & VTSR & Method Date \\
\hline 479235 & & 1 & Liquid & RESORCINOL-FORMALDEHYDE POLYMER & 11 Nov 11 & 11 DeC 11 \\
\hline
\end{tabular}

Test: ASTM E800

Section: FT ADMIN

Holding: 30 days from VTSR

Standard Guide For Measurement Of Gases Present Or Generated During Fires (Gas Sampling Protocol)

\begin{tabular}{|l|c|c|c|c|c|c|}
\hline System ID & Type & Cont & \multicolumn{1}{|c|}{ Matrix } & Customer ID & VTSR & Method Date \\
\hline 479235 & & 1 & Liquid & RESORCINOL-FORMALDEHYDE POLYMER & 11 Nov 11 & 11 DeC 11 \\
\hline
\end{tabular}




\title{
General Sample Chain of Custody
}

\author{
$\operatorname{Ver}(8 / 25 / 2011)$ \\ Southwest Research Institute \\ Chemistry and Chemical Engineering Division \\ 6220 Culebra Road \\ San Antonio, Texas 78238-5166
}

\begin{tabular}{|c|c|c|c|c|c|c|c|}
\hline \multirow{2}{*}{\multicolumn{2}{|c|}{$\begin{array}{l}\text { SRR \#: } \\
\text { Project }\end{array}$}} & \multicolumn{4}{|c|}{ Thermometer: } & \multicolumn{2}{|l|}{027} \\
\hline & & $13295.12 .00 X$ & \multicolumn{3}{|c|}{ Temperature: } & \multicolumn{2}{|l|}{22.0} \\
\hline \multicolumn{2}{|l|}{ CASE: } & 167930 & \multicolumn{3}{|c|}{ Airbill \#: } & \multicolumn{2}{|l|}{404742686287} \\
\hline \multicolumn{2}{|l|}{ Customer: } & BATTELLE PNNL & \multicolumn{3}{|c|}{ Logged in by: } & \multicolumn{2}{|l|}{ DROMAN } \\
\hline \multicolumn{2}{|c|}{ Samples Received: } & Nov 112011 8:30AM & \multicolumn{3}{|c|}{ Logged in: } & \multicolumn{2}{|l|}{ Nov 112011 9:43AM } \\
\hline \multicolumn{2}{|l|}{ Manager: } & \multicolumn{6}{|l|}{ HORTON, GENE } \\
\hline \multicolumn{8}{|c|}{ uthorization. *** DROMAN Nov 112011 9:43AM ** } \\
\hline System ID & \multicolumn{2}{|c|}{ Customer ID } & CED & Matrix & \# Cont & Special Requirements & Sample Condition \\
\hline 479235 & RESOF & CINOL-FORMALDEHYDE POLYMER & & Liquid & 1 & & Intact \\
\hline \multicolumn{3}{|c|}{ Reliquished by (Print/Signature): } & & & & $\begin{array}{r}\text { Date } \\
11 / 1\end{array}$ & $\begin{array}{r}\text { Time } \\
0830\end{array}$ \\
\hline \multicolumn{3}{|c|}{ Received by (Print/Signature): } & & & & $\begin{array}{l}\text { Date } \\
12 / 2\end{array}$ & $\begin{aligned} \text { Time } & \\
& 0830\end{aligned}$ \\
\hline \multicolumn{6}{|c|}{ Reliquished by (Print/Signature): } & Date & Time \\
\hline \multicolumn{6}{|c|}{ Received by (Print/Signature): } & Date & Time \\
\hline \multicolumn{6}{|c|}{ Reliquished by (Print/Signature): } & Date & Time \\
\hline
\end{tabular}


Traffic Report

Sample Custodian Signature:

1. Custody Seal

2. Chain of Custody

3. Sample Tags Sample Tag Numbers

4. SMO Forms
Sogthwest Research Institute

Project: 13295.12-00X

Case: $167930 /$ SDG:

Sample Receipt: 46069

Airbill: 404742686287

\begin{tabular}{|c|c|c|c|c|c|c|c|}
\hline \multirow{2}{*}{$\begin{array}{c}\text { Date } \\
\text { Received }\end{array}$} & \multirow{2}{*}{$\begin{array}{c}\text { Time } \\
\text { Received }\end{array}$} & \multirow[t]{2}{*}{ COC Record } & \multirow[t]{2}{*}{ SMO Sample \# } & \multicolumn{2}{|c|}{ Corresponding } & \multirow{2}{*}{$\begin{array}{c}\text { Traffic Rpt, } \\
\text { Tags, COC } \\
\text { Agree }\end{array}$} & \multirow{2}{*}{$\begin{array}{l}\text { Sample } \\
\text { Condition }\end{array}$} \\
\hline & & & & Sample Tag \# & SwRI \# & & \\
\hline $11 / 11 / 11$ & 08:30:00 & SwRI COC & $\begin{array}{l}\text { RESORCINOL-FORM } \\
\text { POIYMER }\end{array}$ & & 479235 & YES & Intact \\
\hline
\end{tabular}




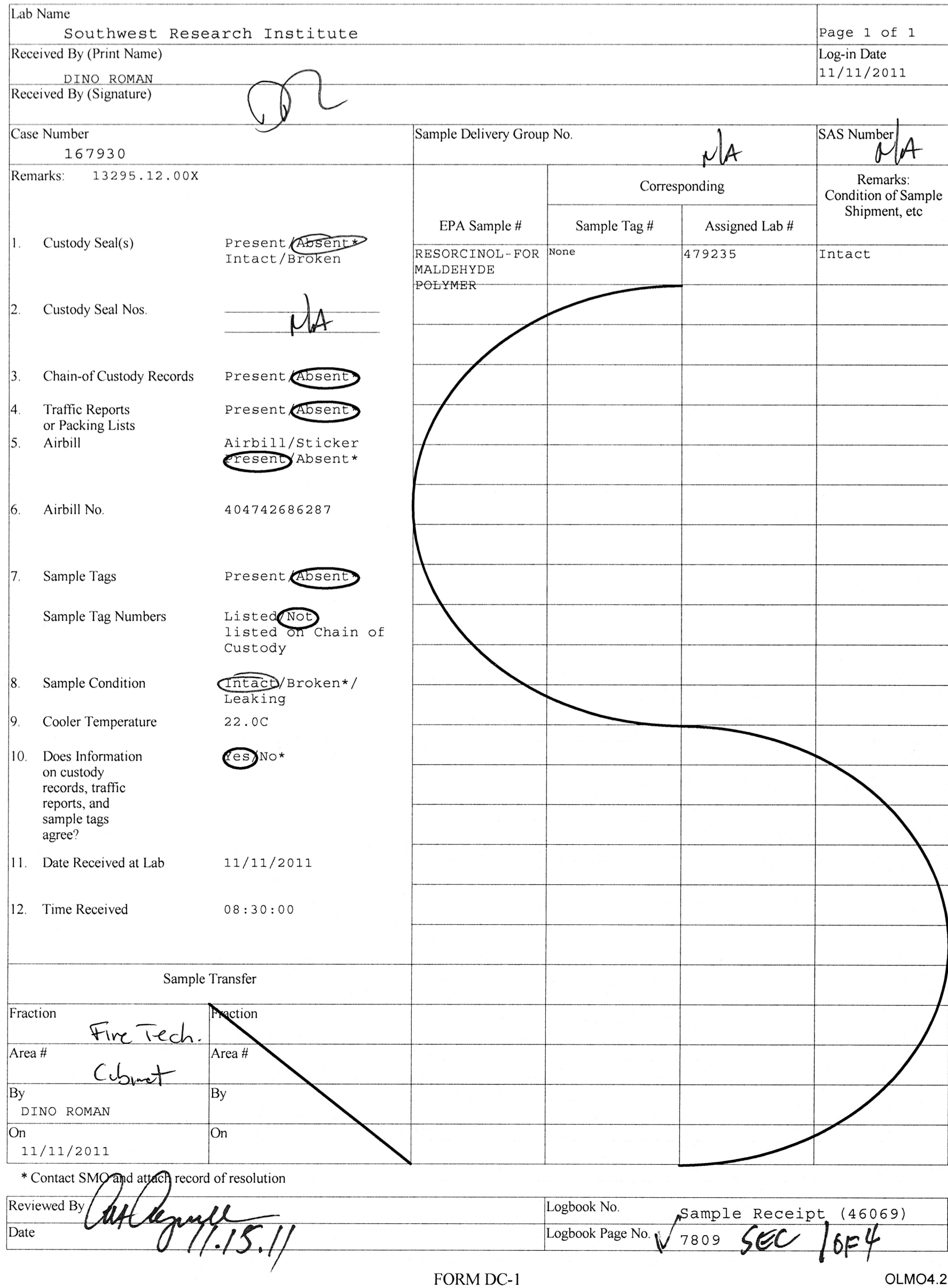




\section{S O U T H W E S T R E S A R C H I N S T I T U T E ${ }^{\circledR}$}

ASTM D 1929 - 96 (RE-APPROVED 2001), STANDARD

TEST METHOD FOR DETERMINING IGNITION

TEMPERATURE OF PLASTICS

MATERIAL ID: RESORCINOL-FORMALDEHYDE POLYMER

FINAL REPORT (Revised)

Consisting of 10 Pages

SwRI ${ }^{\circledR}$ Project No. 01.13295.12.008a

Test Dates: November 29, and December 1-3 and 5, 2011

Report Date: February 2, 2012

Prepared for:

Battelle Memorial Institute

902 Battelle Blvd, K6-79

P.O. Box 999

Richland, WA 99352

Submitted by:

Approved by:

Eugene F. Horton

Senior Engineering Technologist

Matthew S. Blais, Ph.D.

Material Flammability Section

Director

Fire Technology Department

This report is for the information of the client. It may be used in its entirety for the purpose of securing product acceptance from duly constituted approval authorities. This report shall not be reproduced except in full, without the written approval of SwRI. Neither this report nor the name of the Institute shall be used in publicity or advertising. 


\subsection{INTRODUCTION}

ASTM D 1929, Standard Test Method for Determining Ignition Temperature of Plastics, covers a laboratory determination of the spontaneous ignition temperature (SIT) and flash ignition temperature (FIT) of plastics using a hot-air furnace. The hot-air ignition furnace consists primarily of an electrical heating unit and specimen holder. The furnace tube is a vertical tube with an inside diameter of $100 \pm 5 \mathrm{~mm}$ and a length of $230 \pm 20 \mathrm{~mm}$, made of ceramic that will withstand at least $750{ }^{\circ} \mathrm{C}$. The inner ceramic tube, with an inside diameter of $75 \pm 5 \mathrm{~mm}$, a length of $230 \pm 20 \mathrm{~mm}$, and a thickness of approximately $3 \mathrm{~mm}$, is placed inside the furnace tube and positioned $20 \pm 2 \mathrm{~mm}$ above the furnace floor on spacer blocks. The pilot flame is located immediately above the opening. The test apparatus is shown in Figure 1.

Testing was performed on the test samples in accordance with the quality assurance requirements of the DOE/RL-96-68, Hanford Analytical Services Quality Assurance Requirements Documents, Volumes 1 and 4 (HASQARDS), latest revision. In accordance with the HASQARDs, a positive, a negative, and duplicate tests were run, in addition to the one standard test. The positive tests were performed on PMMA (Poly methyl methacrylate). This is a know standard used in testing and it was selected as the positive standard. The negative tests were performed on marinate board, which is a non-combustible material. This material is often used as a substrate or backer board in standard fire testing. It does not react to flame or heat except to lose moisture.

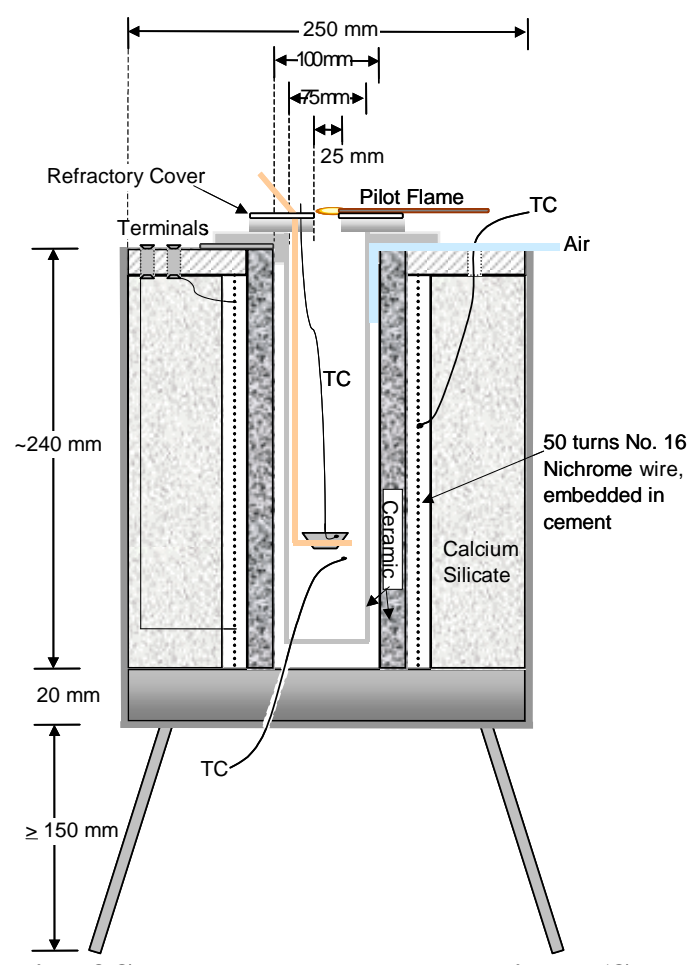

Figure 1. Schematic of Southwest Research Institute (SwRI) Hot-Air Furnace.

SIT is the minimum temperature at which the self-heating properties of the specimen lead to ignition or ignition occurs of itself, under specified test conditions, in the absence of any additional 
flame ignition source. The lowest air temperature at which the specimen ignites during a 10-min period is recorded as the spontaneous ignition temperature.

FIT is the minimum temperature at which, under specified test conditions, sufficient flammable gases are emitted to ignite momentarily upon application of a small external pilot flame. The lowest air temperature at which a flash is observed during a 10-min period is recorded as the flash ignition temperature.

\subsection{SAMPLE IDENTIFICATION AND PREPARATION}

Battelle Memorial Institute, located in Richland, Washington, provided a material identified as Resorcinol-Formaldehyde Polymer for testing in accordance with ASTM D 1929. A description of the material provided by the client can be found in Table 1. On November 11, 2011, SwRI received one 20-L bottle of specimen described in the table below.

TABle 1. SAMPle Description Provided by BATtelle Memorial InSTITUTE.

\begin{tabular}{|c|c|c|}
\hline Material ID & Description & Color \\
\hline \hline Resorcinol-Formaldehyde Polymer & Micro Bead & Red \\
\hline
\end{tabular}

The samples provided consisted of a micro bead material dispersed in water. The material was tested in worst case scenario, which is with the water removed. This process was achieved by first filtering the material, and then drying it in an oven. The sample was dried for a minimum of $10 \mathrm{~h}$ at $60{ }^{\circ} \mathrm{C} \pm 3{ }^{\circ} \mathrm{C}\left(140^{\circ} \mathrm{F} \pm 5^{\circ} \mathrm{F}\right)$ prior to testing. After drying, the sample consisted of only the micro bead material; the beads became statically charged in the absence of the water medium and; therefore, they were placed in a closed container after drying, in an effort not to lose any beads. Each sample was then conditioned in a controlled environment maintained at $23{ }^{\circ} \mathrm{C} \pm 3{ }^{\circ} \mathrm{C}$ and $50 \% \pm 5 \%$ relative humidity until just prior to testing, but for not less than $40 \mathrm{~h}$ prior to testing.

\subsection{RESULTS}

Testing was conducted November 29, and December 1-3 and 5, 2011. Table 2 contains the results for the material provided by Battelle Memorial Institute. Test results are accurate to $\pm 5{ }^{\circ} \mathrm{C}$, and are presented in detail at the end of this report. These test results relate only to the behavior of test specimens under the particular conditions of the test. They are not intended to be used, and shall not be used, to assess the potential fire hazards of a material in use.

TABLE 2. IgNiTION TEMPERATURE DATA.

\begin{tabular}{|c|c|c||}
\hline Material ID & SIT & FIT \\
\hline Resorcinol-Formaldehyde Polymer & $615^{\circ} \mathrm{C}$ & $600{ }^{\circ} \mathrm{C}$ \\
\hline Resorcinol-Formaldehyde Polymer (Duplicate Run) & $610^{\circ} \mathrm{C}$ & $590^{\circ} \mathrm{C}$ \\
\hline Marinite, Negative Standard & NA & NA \\
\hline$P M M A$, Positive Standard & $420^{\circ} \mathrm{C}$ & NA \\
\hline
\end{tabular}


APpendiX A

ASTM D 1929 TEST DATA SHEETS

(Consisting of 6 PAges) 
SOUTHWEST RESEARCH INSTITUTE

\section{ASTM D 1929 TEST DATA SHEET - SPONTANEOUS IGNITION}

Client:

Operator:

Test Date(s):

Material ID*:

Description*:
Battelle Memorial Institute

A. Lowry

December 3 and 5, 2011

PMMA, Positive Standard

Solid Black Composite
Ignition Type:
Receipt Date:
Date Prepared by SwRI:

Color:

Average Sample Mass:
Spontaneous

November 11, 2011

Prepared within $48 \mathrm{~h}$ test

Black

$3.01 \mathrm{~g}$

SPONTANEOUS IGNITION TEMPERATURE $\left({ }^{\circ} \mathrm{C}\right)$ :

420

* Information/instructions provided by the Client

\section{RESULTS}

\begin{tabular}{|c|c|c|c|c|c|c|c|c|c|c|}
\hline Test ID & I Initial & Final & Mass & \multicolumn{3}{|c|}{ Initial Temperature $\left({ }^{\circ} \mathrm{C}\right)$} & \multicolumn{3}{|c|}{ Final Temperature $\left({ }^{\circ} \mathrm{C}\right)$} & Ignition \\
\hline 11-337PNN008F65 & 3.15 & 0.75 & 2.40 & 417 & 410 & 467 & 422 & 407 & 474 & No \\
\hline
\end{tabular}

\section{SPONTANEOUS IGNITION OBSERVATIONS}

\begin{tabular}{|c|c|c|c|c|c|c|c|c|c|}
\hline & $\begin{array}{l}1 \\
1 \\
1 \\
1\end{array}$ & $\begin{array}{l}\text { Insertion } \\
\text { Time } \\
\text { (min:s) }\end{array}$ & $\begin{array}{l}\text { Observed } \\
\text { Smoke } \\
\text { (min:s) }\end{array}$ & $\begin{array}{c}\text { Combustion } \\
\text { Time } \\
\text { (min:s) }\end{array}$ & $\begin{array}{c}\text { Observed } \\
\text { Soot }\end{array}$ & $\begin{array}{c}\text { Observed } \\
\text { Charring }\end{array}$ & $\begin{array}{c}\text { Observed } \\
\text { Melt }\end{array}$ & $\begin{array}{l}\text { Observed } \\
\text { Bubbling }\end{array}$ & $\begin{array}{c}\text { Total Test } \\
\text { Time } \\
\text { (min:s) }\end{array}$ \\
\hline 11-337PNN008F65 & 1 & $0: 36$ & NA & NA & None & Yes & None & Yes & $10: 36$ \\
\hline 11-337PNN008F45 & I & $0: 34$ & NA & $5: 15$ & None & Yes & None & None & $10: 34$ \\
\hline
\end{tabular}

Positive Standard SIT Test

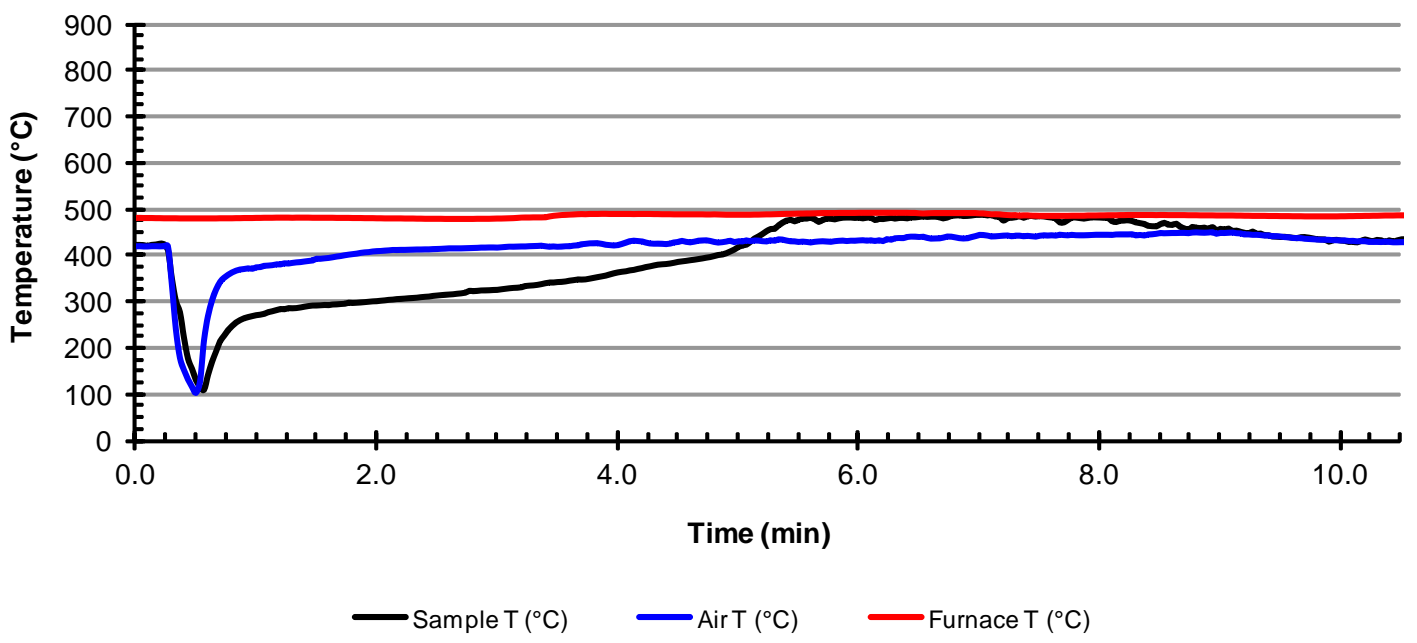


S OUTHWES T RESEARCH INS TITUTE

\section{ASTM D 1929 TEST DATA SHEET - SPONT ANEOUS IGNITION}

$\begin{array}{ll}\text { Client: } & \text { Battelle Memorial Institute } \\ \text { Operator: } & \text { A. Lowery } \\ \text { Test Date(s): } & \text { December 2, } 2011 \\ & \text { Marinate } \\ \text { Mescrial ID*: } & \text { Solid Fire resistant backer board }\end{array}$

Ignition Type:

Receipt Date:

Date Prepared by SWRI:

Color:

Average Sample Mass:
Spontaneous

In stock

Prepared within 48h test

White

$2.89 \mathrm{~g}$

* Information/instructions provided by the Client

\section{RESULTS}

\begin{tabular}{|c|c|c|c|c|c|c|c|c|c|c|}
\hline \multirow[t]{2}{*}{ Test ID } & \multirow{2}{*}{$\begin{array}{cc}\text { I } & \text { Initial } \\
\text { I } & \text { Mass } \\
\text { I } & (g)\end{array}$} & \multirow{2}{*}{$\begin{array}{c}\text { Final } \\
\text { Mass } \\
(\mathrm{g})\end{array}$} & \multirow{2}{*}{$\begin{array}{l}\text { Mass } \\
\text { Loss } \\
(\mathrm{g})\end{array}$} & \multicolumn{3}{|c|}{ Initial Temperature $\left({ }^{\circ} \mathrm{C}\right)$} & \multicolumn{3}{|c|}{ Final Temperature $\left({ }^{\circ} \mathrm{C}\right)$} & \multirow[b]{2}{*}{ Ignition } \\
\hline & & & & Sample & Air & Furnace & Sample & Air & Furnace & \\
\hline 11-336PNN008E1S & $\begin{array}{ll}1 & 2.89 \\
\text { I } & \end{array}$ & 2.62 & 0.27 & 750 & 750 & 809 & $\begin{array}{l}1 \\
1 \\
1\end{array}$ & 753 & 809 & $\mathrm{NO}$ \\
\hline
\end{tabular}

\section{SPONTANEOUS IGNITION OBSERVATIONS}

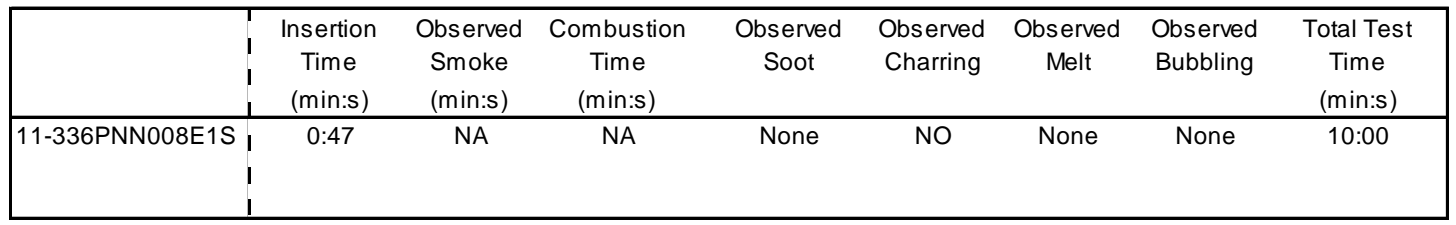

Marinite SIT Negative Standard

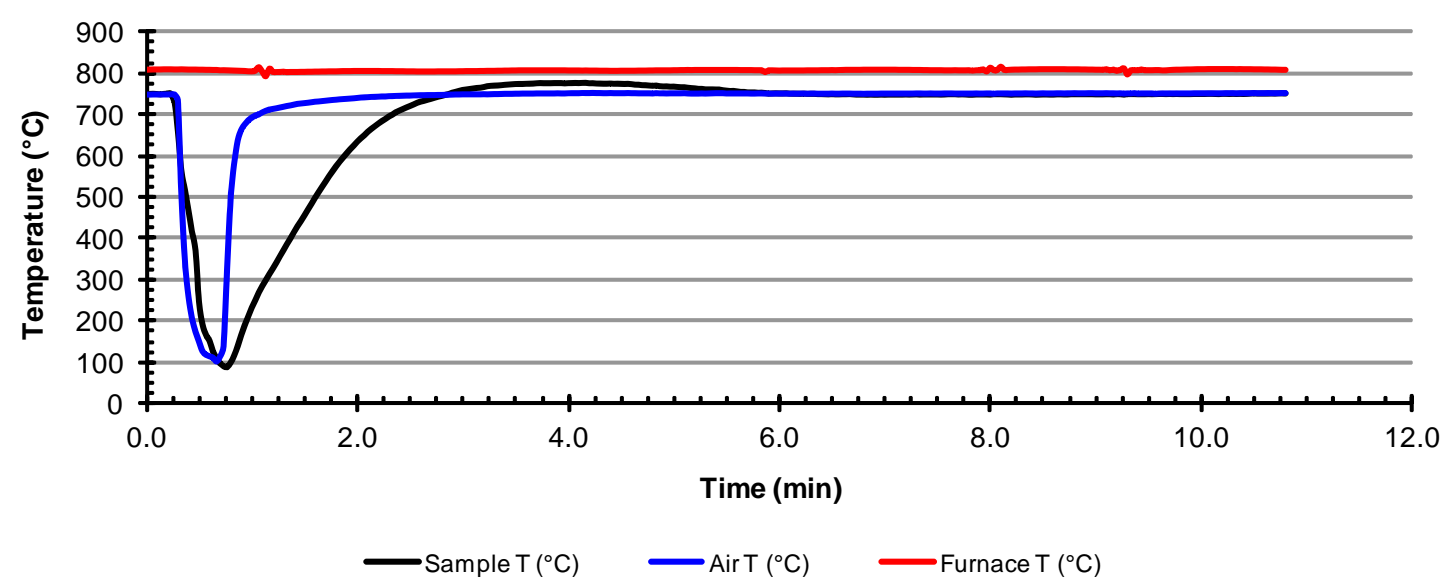


S OUTHWEST RES EARCH INS TITUTE

\section{ASTM D 1929 TEST DATA SHEET - SPONT ANEOUS IGNITION}

Client:

Operator:

Test Date(s):

Material ID*:

Description*:
Battelle Memorial Institute

Nathaniel Ramos

November 29, 2011

Resorcinol-Formaldehyde Polymer

Small Beads
Ignition Type:

Receipt Date:

Date Prepared by SWRI:

Color:

Average Sample Mass:
Spontaneous

November 11, 2011

Prepared within $48 \mathrm{~h}$ test

Red

$3.00 \mathrm{~g}$

* Information/instructions provided by the Client

SPONTANEOUS IGNITION TEMPERATURE $\left({ }^{\circ} \mathrm{C}\right)$ :

615

\section{RESULTS}

\begin{tabular}{|c|c|c|c|c|c|c|c|c|c|c|}
\hline \multirow[t]{2}{*}{ Test ID } & \multirow{2}{*}{$\begin{array}{c}\text { Initial } \\
\text { Mass } \\
(\mathrm{g})\end{array}$} & \multirow{2}{*}{$\begin{array}{c}\text { Final } \\
\text { Mass } \\
(\mathrm{g})\end{array}$} & \multirow{2}{*}{$\begin{array}{c}\text { Mass } \\
\text { Loss } \\
(\mathrm{g})\end{array}$} & \multicolumn{3}{|c|}{ Initial Temperature $\left({ }^{\circ} \mathrm{C}\right)$} & \multicolumn{3}{|c|}{ Final Temperature $\left({ }^{\circ} \mathrm{C}\right)$} & \multirow[b]{2}{*}{ Ignition } \\
\hline & & & & Sample & Air & Furnace & Sample & Air & Furnace & \\
\hline 11-333PNN00A65 & 3.00 & 1.24 & 1.76 & 615 & 615 & 675 & 670 & 626 & 678 & Yes \\
\hline 11-333PNN00A55 & 3.00 & 1.25 & 1.75 & 630 & 625 & 684 & 676 & 635 & 687 & Yes \\
\hline
\end{tabular}

SPONTANEOUS IGNITION OBSERVATIONS

\begin{tabular}{|c|c|c|c|c|c|c|c|c|}
\hline & $\begin{array}{l}\text { Insertion } \\
\text { Time } \\
\text { (min:s) }\end{array}$ & $\begin{array}{l}\text { Observed } \\
\text { Smoke } \\
\text { (min:s) }\end{array}$ & $\begin{array}{c}\text { Combustion } \\
\text { Time } \\
\text { (min:s) }\end{array}$ & $\begin{array}{c}\text { Observed } \\
\text { Soot }\end{array}$ & $\begin{array}{c}\text { Observed } \\
\text { Charring }\end{array}$ & $\begin{array}{c}\text { Observed } \\
\text { Melt }\end{array}$ & $\begin{array}{c}\text { Observed } \\
\text { Bubbling }\end{array}$ & $\begin{array}{l}\text { Total Test } \\
\text { Time } \\
\text { (min:s) }\end{array}$ \\
\hline 11-333PNN00A75 & $1: 56$ & NA & $0: 00$ & None & Yes & None & None & $10: 00$ \\
\hline 11-333PNN00A65 & $1: 23$ & NA & $2: 21$ & None & Yes & None & None & $10: 00$ \\
\hline 11-333PNN00A55 & $1: 42$ & NA & $2: 35$ & None & Yes & None & None & $10: 00$ \\
\hline
\end{tabular}

Fermaldehyde SIT Test 1

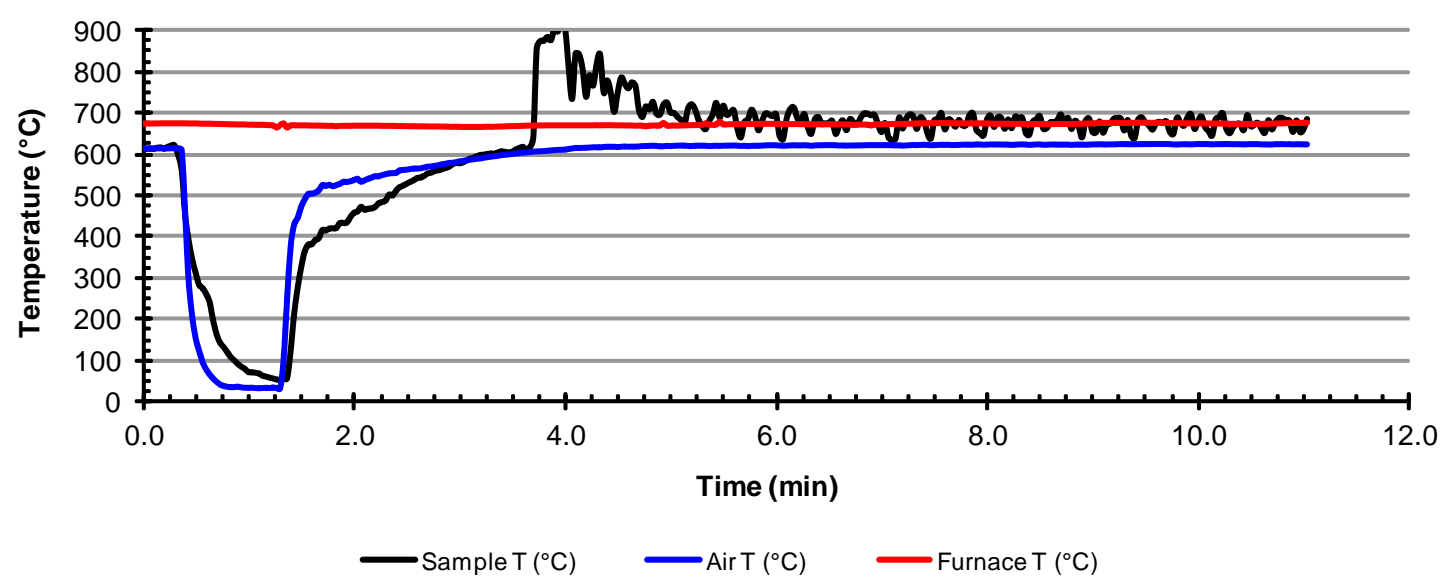


S OUTHWEST RES EARCH INSTITUTE

\section{ASTM D 1929 TEST DATA SHEET - FLASH IGNITION}

Client:

Operator:

Test Date(s):

Material ID*:

Description*
Battelle Memorial Institute

Nathaniel Ramos

December 1, 2011

Resorcinol-Formaldehyde Polymer Small Beads
Ignition Type:

Receipt Date:

Date Prepared by SwRI:

Color:

Average Sample Mass:
Flash

November 11, 2011

Prepared within $48 \mathrm{~h}$ test

Red

$3.00 \mathrm{~g}$

*Information/instructions provided by the Client

RLASH IGNITION TEMPERATURE $\left({ }^{\circ} \mathrm{C}\right): \quad 600$

\section{RESULTS}

\begin{tabular}{|c|c|c|c|c|c|c|c|c|c|c|c|}
\hline \multirow[t]{2}{*}{ Test ID } & \multirow{2}{*}{$\begin{array}{c}\text { Initial } \\
\text { Mass } \\
(\mathrm{g})\end{array}$} & \multirow{2}{*}{$\begin{array}{c}\text { Final } \\
\text { Mass } \\
(\mathrm{g})\end{array}$} & \multirow{2}{*}{$\begin{array}{c}\text { Mass } \\
\text { Loss } \\
(\mathrm{g})\end{array}$} & \multicolumn{3}{|c|}{ Initial Temperature $\left({ }^{\circ} \mathrm{C}\right)$} & \multicolumn{3}{|c|}{ Final Temperature $\left({ }^{\circ} \mathrm{C}\right)$} & \multicolumn{2}{|c|}{1} \\
\hline & & & & Sample & Air & Furnace & Sample & Air & Furnace & 1 & Ignition \\
\hline 11-336PNN00B4F & 3.00 & 1.53 & 1.47 & 591 & 590 & 649 & 628 & 598 & 648 & 1 & No \\
\hline 11-335PNN00B1F & 3.00 & 1.66 & 1.34 & 603 & 600 & 660 & 653 & 608 & 663 & & Yes \\
\hline
\end{tabular}

\section{FLASH IGNITION OBSERVATIONS}

\begin{tabular}{|c|c|c|c|c|c|c|c|c|}
\hline & $\begin{array}{l}\text { Insertion } \\
\text { Time } \\
\text { (min:s) }\end{array}$ & $\begin{array}{c}\text { Observed } \\
\text { Smoke } \\
\text { (min:s) }\end{array}$ & $\begin{array}{c}\text { Combustion } \\
\text { Type } \\
\text { (min:s) }\end{array}$ & $\begin{array}{c}\text { Observed } \\
\text { Soot } \\
\text { (min:s) }\end{array}$ & $\begin{array}{c}\text { Observed } \\
\text { Charring }\end{array}$ & $\begin{array}{c}\text { Observed } \\
\text { Melt }\end{array}$ & $\begin{array}{c}\text { Observed } \\
\text { Bubbling }\end{array}$ & $\begin{array}{c}\text { Total Test } \\
\text { Time } \\
\text { (min:s) }\end{array}$ \\
\hline 11-335PNN00B1F & $0: 59$ & NA & Flaming at $5: 15$ & None & Yes & None & None & $8: 26$ \\
\hline
\end{tabular}

Fermaldehyde FIT Test 1

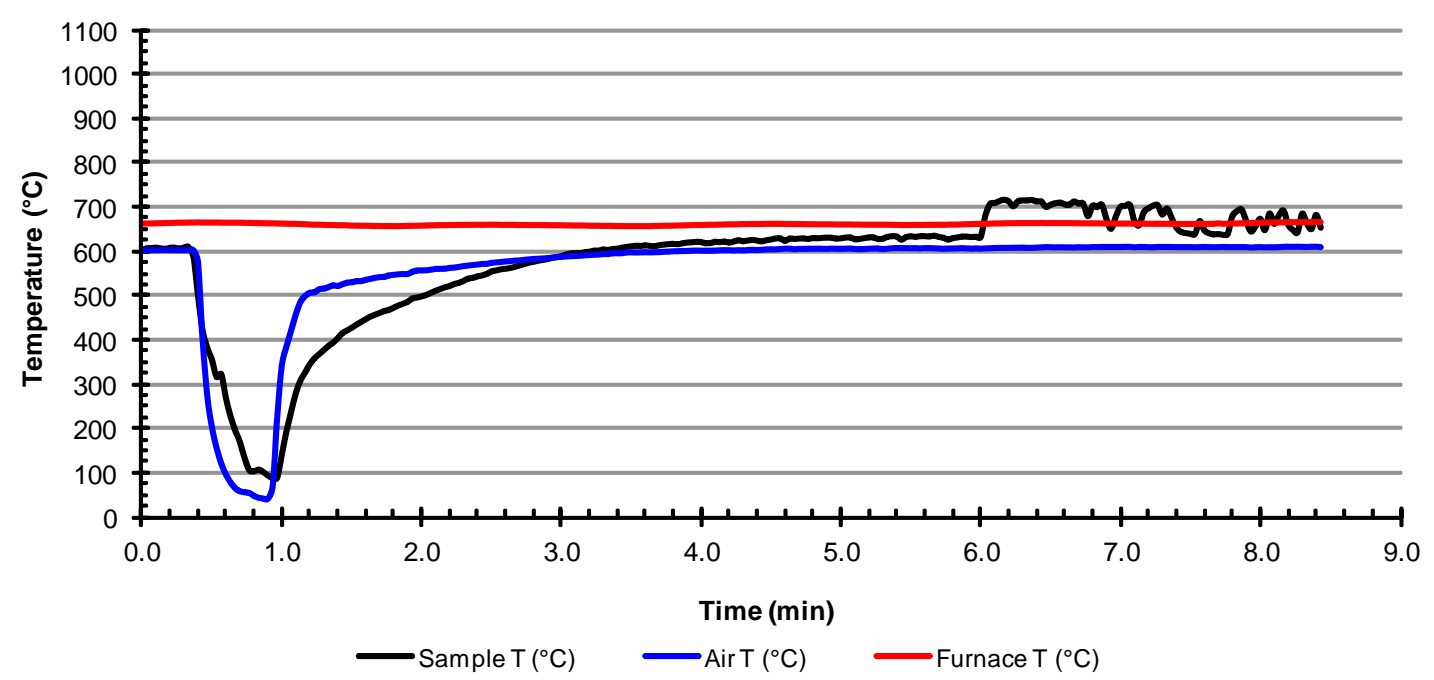


S OUTHWEST RESEARCH INSTITUTE

\section{ASTM D 1929 TEST DATA SHEET - SPONT ANEOUS IGNITION}

Client:

Operator:

Test Date(s):

Material ID*:

Description*
Battelle Memorial Institute

A. Lowry

December 2, 2011

Resorcinol-Formaldehyde Polymer

Small Beads
Ignition Type:

Receipt Date:

Date Prepared by SwRI:

Color:

Average Sample Mass:
Spontaneous

November 11, 2011

Prepared within $48 \mathrm{~h}$ test

Red

$3.00 \mathrm{~g}$

* Information/instructions provided by the Client

\section{RESULTS}

\begin{tabular}{|c|c|c|c|c|c|c|c|c|c|c|c|c|c|}
\hline \multirow[t]{2}{*}{ Test ID } & 1 & Initial & Final & Mass & \multicolumn{4}{|c|}{ Initial Temperature $\left({ }^{\circ} \mathrm{C}\right)$} & \multicolumn{3}{|c|}{ Final Temperature $\left({ }^{\circ} \mathrm{C}\right)$} & 1 & \multirow[b]{2}{*}{ Ignition } \\
\hline & $\begin{array}{l}1 \\
1\end{array}$ & $\begin{array}{c}\text { Mass } \\
(\mathrm{g})\end{array}$ & $\begin{array}{c}\text { Mass } \\
(\mathrm{g})\end{array}$ & $\begin{array}{c}\text { Loss } \\
(\mathrm{g})\end{array}$ & I & Sample & Air & Furnace & I Sample & Air & Furnace & $\perp$ & \\
\hline 11-336PNN00D1S & 1 & 3.00 & 1.54 & 1.46 & I & 603 & 600 & 658 & 640 & 609 & 658 & I & No \\
\hline 11-336PNN00D2S & I & 3.00 & 1.76 & 1.24 & $\begin{array}{l}1 \\
1\end{array}$ & 611 & 610 & 669 & 659 & 619 & 670 & I & Yes \\
\hline
\end{tabular}

\section{SPONTANEOUS IGNITION OBSERVATIONS}

\begin{tabular}{|c|c|c|c|c|c|c|c|c|c|}
\hline & $\begin{array}{l}1 \\
1 \\
1\end{array}$ & $\begin{array}{l}\text { Insertion } \\
\text { Time } \\
\text { (min:s) }\end{array}$ & $\begin{array}{l}\text { Observed } \\
\text { Smoke } \\
\text { (min:s) }\end{array}$ & $\begin{array}{c}\text { Combustion } \\
\text { Time } \\
\text { (min:s) }\end{array}$ & $\begin{array}{c}\text { Observed } \\
\text { Soot }\end{array}$ & $\begin{array}{c}\text { Observed } \\
\text { Charring }\end{array}$ & $\begin{array}{c}\text { Observed } \\
\text { Melt }\end{array}$ & $\begin{array}{c}\text { Observed } \\
\text { Bubbling }\end{array}$ & $\begin{array}{c}\text { Total Test } \\
\text { Time } \\
\text { (min:s) }\end{array}$ \\
\hline 11-336PNN00D2S & I & $0: 31$ & NA & $2: 34$ & None & Yes & None & None & $6: 00$ \\
\hline
\end{tabular}

Fermaldehyde SIT Test 2 (Duplicate)

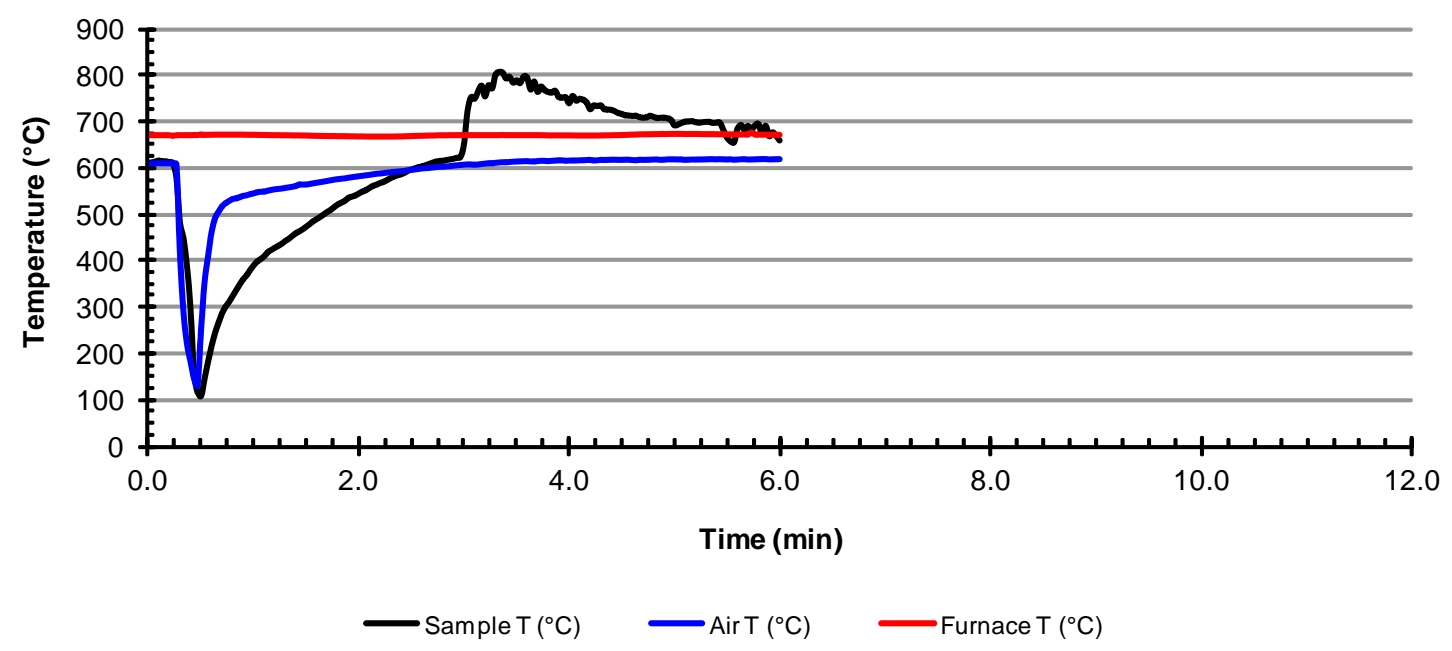


S OUTHWEST RESEARCH INSTITUTE

\section{ASTM D 1929 TEST DATA SHEET - FLASH IGNITION}

\author{
Client: \\ Operator: \\ Test Date(s): \\ Material ID*: \\ Description*: \\ Battelle Memorial Institute \\ A. Lowry \\ December 2, 2011 \\ Resorcinol-Formaldehyde Polymer \\ Small Beads
}

Ignition Type: Flash

Receipt Date: $\quad$ November 11, 2011

Date Prepared by SwRI: Prepared within $48 \mathrm{~h}$ test

Color: Red

Average Sample Mass: $3.00 \mathrm{~g}$

* Information/instructions provided by the Client

RLASH IGNITION TEMPERATURE $\left({ }^{\circ} \mathrm{C}\right)$ :

590

\section{RESULTS}

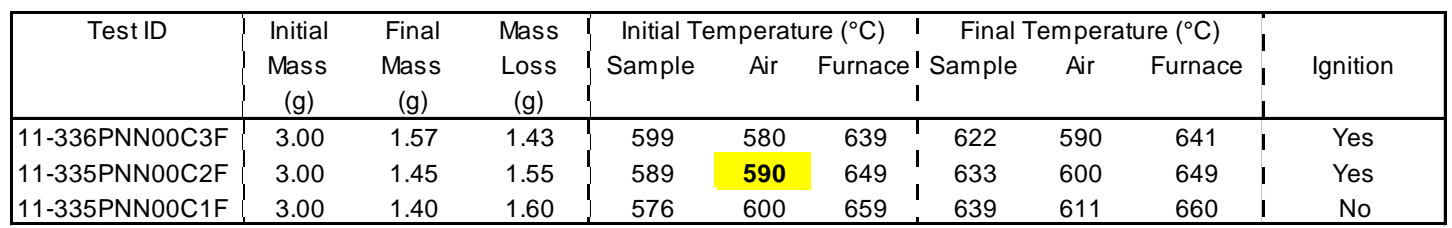

\section{FLASH IGNITION OBSERVATIONS}

\begin{tabular}{|c|c|c|c|c|c|c|c|c|}
\hline & $\begin{array}{l}\text { Insertion } \\
\text { Time } \\
\text { (min:s) }\end{array}$ & $\begin{array}{c}\text { Observed } \\
\text { Smoke } \\
\text { (min:s) }\end{array}$ & $\begin{array}{c}\text { Combustion } \\
\text { Type } \\
\text { (min:s) }\end{array}$ & $\begin{array}{c}\text { Observed } \\
\text { Soot } \\
\text { (min:s) }\end{array}$ & $\begin{array}{c}\text { Observed } \\
\text { Charring }\end{array}$ & $\begin{array}{c}\text { Observed } \\
\text { Melt }\end{array}$ & $\begin{array}{c}\text { Observed } \\
\text { Bubbling }\end{array}$ & $\begin{array}{c}\text { Total Test } \\
\text { Time } \\
\text { (min:s) }\end{array}$ \\
\hline 11-335PNN00C2F & $0: 41$ & NA & Flaming at 5:39 & None & Yes & None & None & $10: 42$ \\
\hline 11-335PNN00C1F & $0: 41$ & NA & Flaming at 5:15 & None & Yes & None & None & $10: 42$ \\
\hline
\end{tabular}

Fermaldehyde FIT Test 2 (Duplicate)

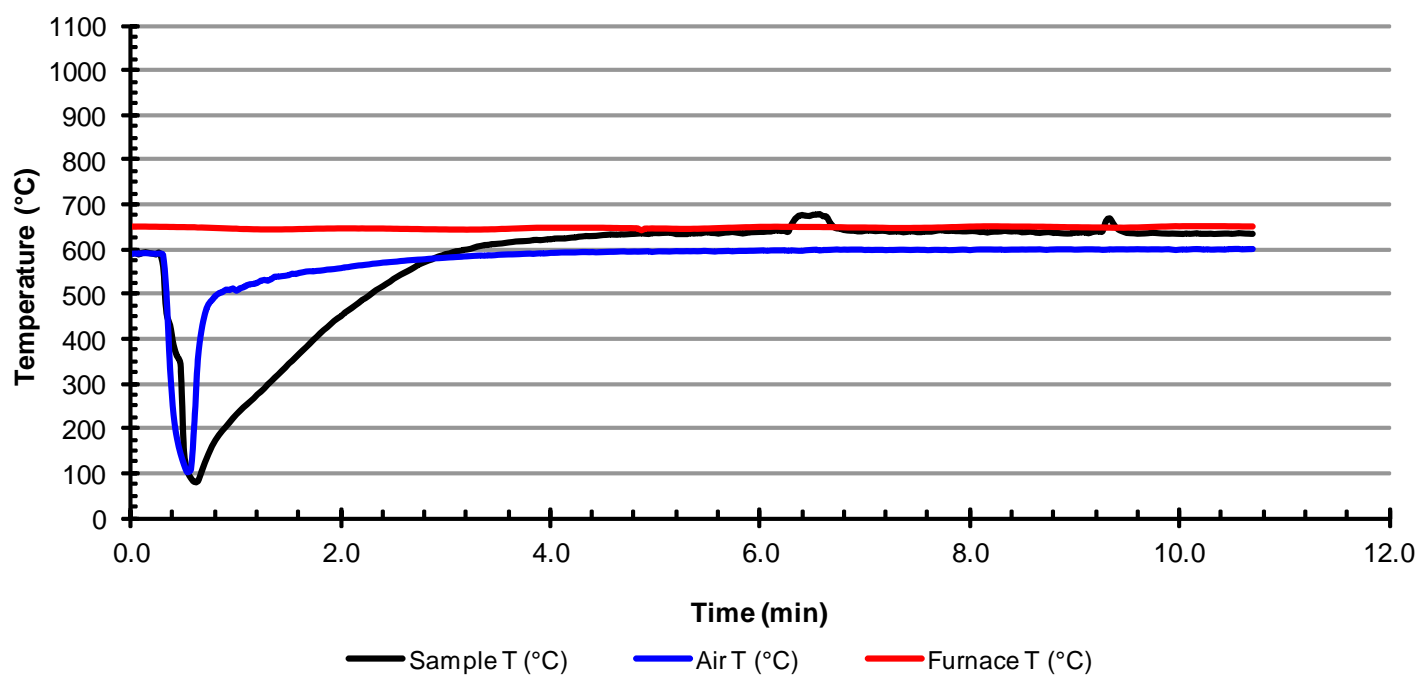


PNNL-21321

\section{Distribution*}

No. of

Copies

4 Bechtel National, Inc.

SM Barnes

JL Meehan

$\mathrm{H} 4-02$

DJ Sherwood

$\mathrm{H} 4-02$

H4-02

WTP R\&T Docs
No. of

Copies

6 Pacific Northwest National Laboratory

D Kim

DE Kurath

RA Peterson

RL Russell

MJ Schweiger

Project File

Information Release
K6-24

K3-52

$\mathrm{P} 7-22$

K6-24

K6-24

K3-52

*All distribution will be made electronically. 




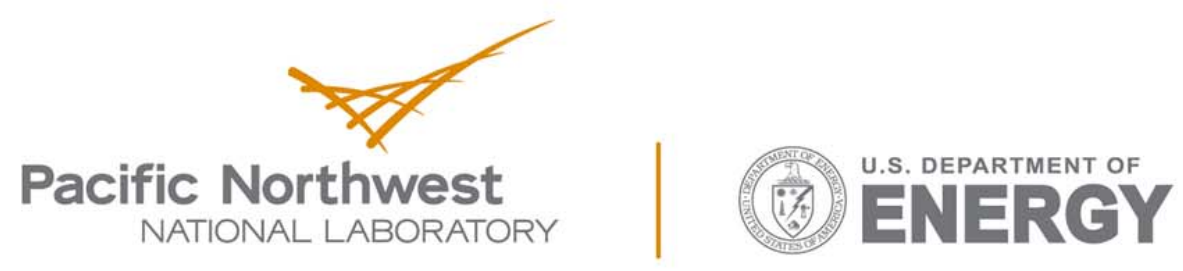

Proudly Operated by Battelle Since 1965

902 Battelle Boulevard

P.O. Box 999

Richland, WA 99352

1-888-375-PNNL (7665)

www.pnnl.gov 